\title{
REMOVING TEMPTATION: \\ NEW ZEALAND'S ALCOHOL \\ RESTRICTIONS, 1881-2005
}

By

Paul John Christoffel

\begin{abstract}
A thesis
submitted to the Victoria University of Wellington in fulfilment of the requirements for the degree of Doctor of Philosophy in History
\end{abstract}

Victoria University of Wellington

2006 
ABSTRACT

This thesis provides an historical overview of the legal restrictions placed on access to alcohol in New Zealand and details some consequences of these restrictions. It questions whether the historical evidence from New Zealand supports the availability theory of alcohol. The availability theory contends that for most societies the per capita consumption of alcohol can be reduced by restricting its availability, thereby reducing alcohol-related harm. The theory was propounded in detail by the international alcohol research community from the 1970 s but was also implicit in 'restrictionist' approaches increasingly adopted in a variety of countries, including New Zealand, in the nineteenth and early twentieth centuries. The thesis focuses primarily on the period from 1881 onwards, when a new Licensing Act formalised the restrictionist principles that were to dominate liquor policy for much of the next century. Until the passing of 1989 Sale of Liquor Act, New Zealand's liquor laws were characterised by strict controls on licence numbers, uniform hours of sale, regular polls on liquor issues and legal obligations to provide accommodation for travellers.

The availability theory was tested by assessing the effect of the rapid changes in alcohol availability that resulted from tax and policy changes that increased or decreased restrictions on access. Large liquor tax increases in 1921 and 1958 were followed by significant and sustained reductions in per capita alcohol consumption. The lowering of the minimum legal age of purchase in 1969 and 1999 was followed by increased alcohol consumption. Both these findings are consistent with the availability theory. However, neither the banning of liquor sales after six pm from December 1917 ('six o'clock closing') nor the resumption of ten o'clock closing from October 1967 had any apparent effect on liquor consumption. Rapid changes in the number of liquor outlets from 1894 to 1910 and from 1990 to 1995 were inversely correlated with changes in per capita alcohol consumption, a finding that is strongly at odds with the availability theory. The findings have relevance for contemporary debates on access to alcohol in Australia (outlet 
numbers) Great Britain (drinking hours and liquor taxes) and New Zealand (the drinking age).

This thesis also attempts to explain why strict controls remained in place for so long given that restrictions on outlet numbers and hours of sale had no apparent impact on liquor consumption. Six o'clock closing lasted for 50 years. A freeze on public house numbers instituted in 1894 remained largely in place for almost 70 years. It is argued that liquor restrictions were maintained primarily because of political inertia engendered by three main factors. Firstly, political parties avoided addressing liquor issues as they tended to threaten party unity. Secondly, repeated referendums provided politicians with a regular reminder of the strength of the temperance lobby, making them wary of reform. Thirdly, there was little lobbying for reform because the restrictions advantaged vested interests within the liquor industry, the controls were commonly believed to reduce alcohol consumption, and the isolation of New Zealand contributed to a lack of exposure to alternatives. 


\section{ACKNOWLEDGMENTS}

I gratefully acknowledge the invaluable contribution of my principal supervisor Charlotte Macdonald, who suggested this topic or at least something very like it. Her insightful and challenging comments and questions encouraged me to regularly re-evaluate my approach. My secondary supervisor Melanie Nolan helped keep me on track in the early stages before going on sabbatical, offering helpful advice and remaining positive and cheerful when it all seemed so overwhelming. Thanks also to Don McRaild who agreed to fill in for Melanie just months after he arrived in the country. I trust the experience did not distort his view of New Zealand history too much. In addition to providing excellent supervision and library support, Victoria University of Wellington contributed financial assistance in the form of a six-month $\mathrm{PhD}$ Completion Scholarship.

Thanks to Sue Page for providing inspiration, to Danny Winter for drawing my attention to some useful references, and to the friends and family (my parents especially) who gave their support and encouragement over the past few years. A special thanks to Penelope and Michael Christoffel who did such a sterling job of proofreading. The final acknowledgement goes to Sharon Brandford, without whose unwavering confidence and support this thesis may never have happened. Thank you Sharon. 


\section{TABLE OF CONTENTS}

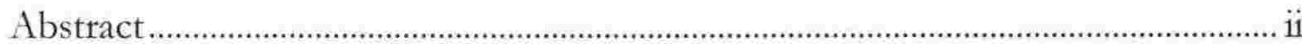

Acknowledgements .........................................................................................................

List of Tables and Figures ....................................................................................

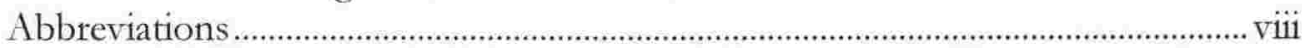

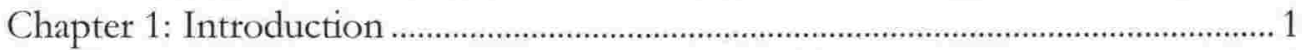

The Historical Background to Restrictionist Thinking …….............................. 10

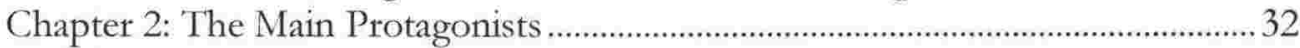

The Temperance and Prohibition Movement .....................................................33

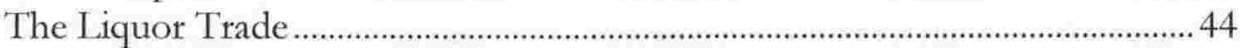

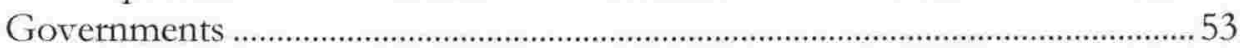

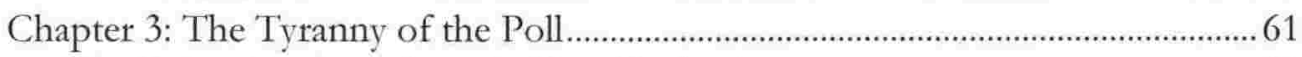

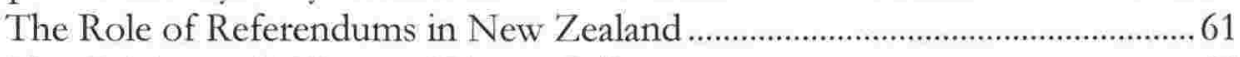

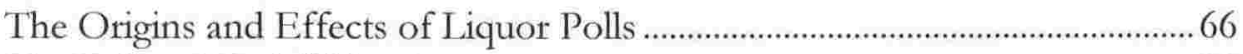

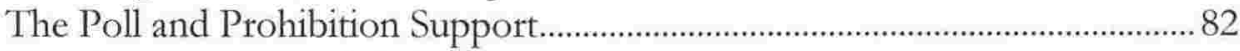

The Consequences of the Poll ........................................................................... 93

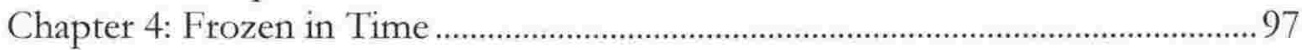

The Origins of the Distribution Problem.......................................................... 98

The Royal Commission on Licensing .................................................................103

The Licensing Control Commission …………….............................................111

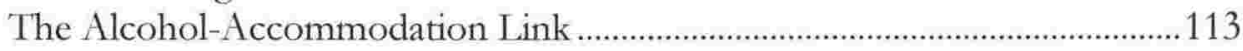

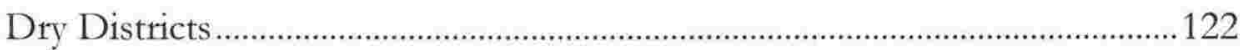

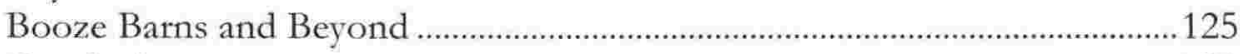

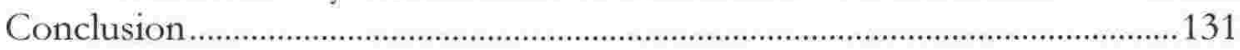

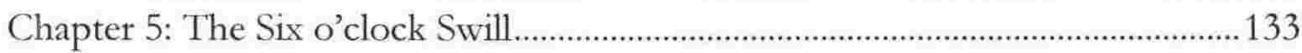

Chapter 6: A Century of Experiments ..........................................................................168

Empirical Evidence and 'Natural Experiments' ..............................................169

Changes in Economic Availability ................................................................179

The Effect of Reduced Outlet Numbers ..........................................................184

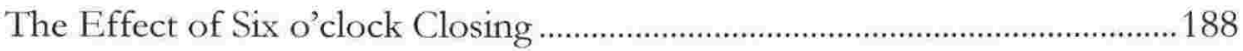

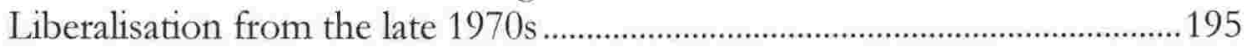

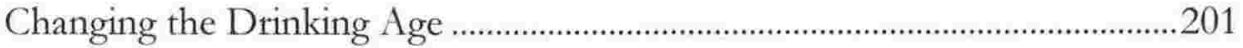

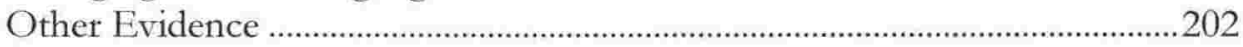

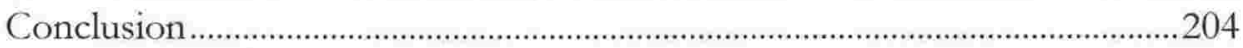

Chapter 7: The Effect and Persistence of Controls.............................................207

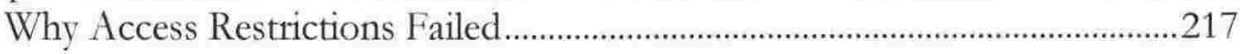

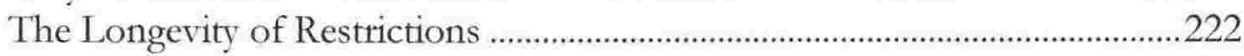

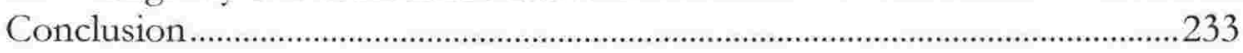

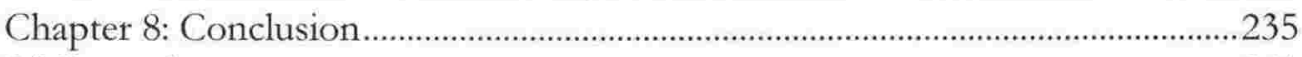

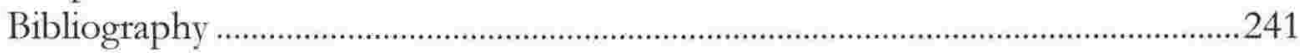




\section{LIST OF TABLES AND FIGURES}

Note: Tables and Figures are numbered according to the chapter they appear in

Table 1: Persons per Hotel Licence in New Zealand and Australian

States, 1893, 1910 and 1950 .28

Table 3.1: National Referendums in 15 Democracies to 1993

Table 3.2: Referendums in Canadian Provinces and New Zealand, 1892-1982

Table 3.3: Referendums in Australian States and New Zealand, 1901-1993

Figure 3.1: Percent Voting for Continuance and State Control, 1919-1949

Figure 3.2: Numbers Voting for Prohibition in General Licensing Polls, 1919-1972

Figure 3.3: Percent Voting for Prohibition in General Licensing

Polls, 1919-1987

Figure 3.4: Numbers Voting Prohibition and State Control, 1960-1987

Figure 4.1: Number of Licensed Hotels per 1000 People, 1894-1910

Figure 4.2: Number of Licensed Liquor Outlets per 1000 People, 1960-2004

Figure 6.1: Consumption of Absolute Alcohol per Person 1911-1927, Pints.....180

Figure 6.2: Consumption of Beer per Person 1913-1938, Gallons 181

Figure 6.3: Consumption of Wine and Spirits per Person 1913-1938,

Gallons

Figure 6.4: Beer Consumption per Capita 1946-1975, Gallons 182

Figure 6.5: Spirits Consumption per Capita 1946-1975, Gallons 183

Figure 6.6: Wine Consumption per Capita 1946-1975, Gallons 183 
Figure 6.7: Consumption of Beer per Person 1882-1915, Gallons

Figure 6.8: Consumption of Wine and Spirits per Person 1882-1915, Gallons

Figure 6.9: Drunkenness Convictions per 1000 People (excluding Maori) 1888-1915

Figure 6.10: Drunkenness Convictions per 1000 People, 1912-1974

Figure 6.11: Maori and Non-Maori Convictions for Drunkenness per 1000 Population, $1947-1976$

Figure 6.12: Estimated Consumption of Absolute Alcohol per Person Aged 15+, 1955-2004, Litres.

Figure 6.13: New Zealand Consumption of Beer per Capita 1981-2001 (Year Ending 30 June), Litres

Figure 6.14: New Zealand Consumption of Spirits Per Capita 1981-2001

(Year Ending 30 June), Litres

Figure 6.15: New Zealand Consumption of Wine Per Capita 1981-2001 (Year Ending 30 June), Litres .200

Figure 7: Drunkenness Charges in Southland Police District as Percent of New Zealand Total, 1903-1919 .210 


\section{ABBREVIATIONS}

AJHR

MHR

MP

NZJH

NZOYB

NZPD

PRCL

Report RCL
Appendices to the Journals of the House of Representatives

Member of the House of Representatives

Member of Parliament

New Zealand Journal of History

New Zealand Official Year Book

New Zealand Parliamentary Debates

Proceedings of the Royal Commission on Licensing

Report of the Royal Commission on Licensing 


\section{INTRODUCTION}

For much of the twentieth century New Zealand imposed significant restrictions on the sale of alcohol, almost all of which were in place by 1918. New Zealand's restrictions were in many ways distinct from those imposed elsewhere. New liquor outlets were effectively prohibited and the sale of alcohol was banned altogether in much of the country. Every three years a national referendum threatened to extend the ban to the rest of New Zealand. The minimum legal age of purchase ('the drinking age') was raised to 21. Most famously, New Zealand became the only country in the world to impose a nation-wide ban on the sale of liquor after six pm ('six o'clock closing'). While falling well short of complete prohibition, liquor regulation was clearly dedicated towards restricting the availability of alcohol.

These restrictions were introduced rapidly and stayed in place for half a century or more. A freeze on public houses was imposed in 1893 along with a mechanism for reducing their numbers through local option polls ('local veto'). By 1910 the number of bars per capita had halved and nearly 20 percent of the population lived in districts in which liquor sales were illegal. The freeze on liquor outlets did not begin to thaw substantially until the 1950s. The drinking age stayed at 21 from 1910 until 1969, and even then it was lowered by just a year. Six o'clock closing was legislated for in October 1917 and came into effect within two months. It lasted for 50 years. But once early closing was removed the remaining restrictions soon followed; slowly at first, then with a rush after the 1989 Sale of Liquor Act completely rewrote the legislative framework. By the year 2000 only a few vestiges of the restrictions that had been central to liquor control for over half of the twentieth century remained. ${ }^{1}$

This thesis covers more than a century of liquor control, primarily the period between the 1881 Licensing Act, which laid the foundation for future restrictions, and 2005, 16 years after a major overhaul of liquor legislation. It addresses two main research questions. The primary question is whether the historical evidence from New Zealand supports the

\footnotetext{
1 All these changes are outlined in detail in this and subsequent chapters.
} 
availability theory of alcohol. The theory contends that 'the degree of alcohol abuse in any community depends on the level of consumption and that in turn depends on the extent to which alcohol is available for sale. Licensing laws should therefore be directed at limiting availability'. The availability theory has had many advocates in recent decades, particularly within the international alcohol research community. However it also has a long history and was the implicit justification for many of the restrictions imposed on the sale of alcohol in New Zealand and elsewhere. In the words of the 1945 Royal Commission on Licensing; 'the misery and degradation associated with drunkenness has induced civilised communities to treat alcoholic liquor....as an article which requires control both in consumption and in trade in the interests of the individual and society. ${ }^{3}$ The controls on alcohol that form the main focus of this thesis are those that attempt to limit its availability through supply-side restrictions, primarily the limits on outlet numbers and hours of sale that formed the centrepiece of liquor control in New Zealand.

The most compelling evidence advanced in favour of the availability theory comes from 'natural experiments' (perhaps more accurately called 'historical experiments') when alcohol availability increases or decreases dramatically over a relatively short period of time. ${ }^{4}$ New Zealand has had several periods in which the changes in outlet numbers or legal hours of sale have been introduced so rapidly as to constitute an historical experiment through which the availability theory can be tested. The main periods to be looked at in this regard are the local veto period from 1894 to 1910 when the number of public houses per capita was halved; the introduction of 'six o'clock closing' in 1917; its ending in 1967; and the doubling in the number of liquor outlets per capita between 1990 and 2004. The thesis also examines the effects of sudden increases in alcohol taxes and changes in the drinking age. In all cases the main question to be examined is whether introducing these restrictions led to a reduction in the amount of alcohol consumed and whether removing the restrictions led to more drinking.

\footnotetext{
2 Working Party on Liquor, The Sale of I iquor in New Zealand, Wellington, 1986, p. 30. The working party report refers to the 'availability thesis'.

3 The Royal Commission on Licensing, Report of the Royal Commission on Licensing, Wellington, 1946, p. 21, also available in AJI IR 1946, I I-38, hereafter referred to as Report RCL. The commission held its hearings in 1945 and published its report in 1946.

+ Natural experiments can be distinguished from controlled or artificial experiments, which generally involve techniques such as random assignment of participants to treatment and control groups. 'This distinction is discussed in more detail in Chapter 6.
} 
A secondary question to be addressed is why availability restrictions, once imposed in New Zealand, remained in place for so long. To some extent the answer to this second question depends on the answer to the first one. Clearly if there is evidence that restrictions were effective in suppressing harmful drinking then this would provide an important part of the explanation for their retention. However some have maintained that the restrictions were retained for other reasons. One was Conrad Bollinger whose 1959 book Grog's Own Country provided a brief history of the legal controls over alcohol sales in New Zealand. ${ }^{5}$ Despite its punning title, Bollinger's book was a reasonably scholarly one provoked by frustration at the long-standing retention of numerous restrictions, particularly strict controls on the number and legal opening hours of liquor outlets. He claimed that these restrictions had undesirable social consequences, including over-crowded and unhygienic bars and the unhealthily rapid consumption of liquor. ${ }^{6}$ Bollinger argued that the controls had survived for so many decades because they were supported by a seemingly unlikely alliance of interests - the prohibition and temperance movement and the liquor industry. The prohibition movement for its part supported any restrictions on the availability of alcohol. The industry was also alleged to have supported controls on the numbers of licences and hours of sale, for such restrictions shielded existing players from competition and helped keep down costs. With short selling hours, restricted numbers of licences, and no need to provide any amenities other than standing room, the maximum amounts of beer can be sold at minimum expense to the vendor. ${ }^{8}$

This thesis takes issue with Bollinger's explanation for the slow rate of change, which placed particular emphasis on the role of the liquor industry in supporting continued restrictions. It will be argued that he overlooked important alternative explanations, including the fact that availability restrictions were widely perceived as limiting the harm caused by alcohol. In addition the institution of regular liquor polls helped keep liquor issues in the public eye, provided a regular reminder of the strength of the prohibition movement, and made politicians wary of change.

\footnotetext{
5 Conrad Bollinger, Grog's Own Country, Wellington, 1959. A sccond cdition of his book was published in 1967, and the two editions will hereafter be distinguished by their dates.

${ }^{6}$ Bollinger, 1959, especially pp. 10-16.

7 'The terms 'temperance' and 'prohibition' are gencrally used interchangeably throughout this thesis, as by the late nineteenth century they were both commonly used to mean imposed abstention from all alcoholic beverages. Those temperance advocates who objected to prohibition were often forced to call themselves supporters of 'true temperance', Paul McKimmey, 'I'he 'lemperance Movement in New 7ealand 1835-1894', M/I thesis, University of Luckland, 1968 , p. 56.

8 Bollinger, 1959, p. 13.
} 
Grog's Own Country remains the main source on the history of liquor regulation in twentieth-century New Zealand. ${ }^{9}$ Subsequent historians have tended to concentrate on what they perceived as the inherently more interesting period of change before 1920 , particularly the rise of the prohibition and temperance movement in the nineteenth and early twentieth centuries. Paul McKimmey in the 1960s and Anthony Grigg and Richard Newman in the 1970 s took the story of the movement and its influence on the wider society through to the First World War, when it was perhaps at its strongest. ${ }^{10}$ These historians were stimulated by different aspects of this early period. One of McKimmey's aims was to try to explain the 'astonishing popularity' of prohibition and temperance. ${ }^{11}$ Grigg used a class-based analysis to try to explain the varying range of support for and opposition to the movement. ${ }^{12}$ Newman aimed to explain the exceptionally high vote for prohibition in the 1911 General Licensing Poll.

These historians to some extent overlooked or downplayed the role of women in the prohibition movement, particularly that of the Women's Christian Temperance Union (WCTU). This gap was filled by a range of writers starting with Patricia Grimshaw in 1972. ${ }^{13}$ Grimshaw was a part of the 'second wave' of feminists who sought to demonstrate that early female temperance campaigners were themselves feminists who had a central role in achieving female suffrage. She challenged views that women's suffrage in New Zealand came about through the progressive attributes of the Liberal Party or the support of male temperance campaigners who believed women voters would support their cause. A range of later writers focused on the lives of individual activists in the campaign for female suffrage. ${ }^{14}$ Others drew attention to the involvement of women, especially the WCTU, in a variety of feminist and social purity issues including

\footnotetext{
"The main exception is Michael Stace, A History of the Liquor Legislation in New Zealand, Wellington, 1988. Despite its title, this monograph deals almost exclusively with changes in government alcohol policy in the period 1960 to 1984 .

10 McKimmey, "The Temperance Movement in New 7ealand', Anthony Grigg, "Ihe Attack on the Citadels of Liquordom: A Study of the Prohibition Movement in New 'Lealand, 1894-1914', PhD thesis, University of Otago, 1977, Richard Newman, New 7.ealand's Vote for Prohibition in 1911', New Zealand Journal of History, vol. 9, no. 1, April 1975 , pp. $52-71$.

11 McKimmey, "The Temperance Movement in New Zealand', p. iii.

12. Grigg's thesis received some support from a regional study by Craig Tumey, "The New 7ealand Alliance and Auckland 1905 - 1920', MA thesis, University of Auckland, 1996.

13 Patricia Grimshaw, Women's Suffrage in New Zealand, Auckland, 1972.

1+ Judith Devailant, Kate Sheppard: a Biography: the Fight for Women's Votes in New Zealand: the Life of the Woman Who Led the Struggle, Auckland, 1992, Charlotte Macdonald, Merimeri Penfold and Bridget Williams, eds., The Book of New Zealand Women, Wellington, 1991, Dorothy Page and Department of Internal Iffairs, The Suffragists: Women Who Worked for the Vote: Essays from the Dictionary of New Zealand Biography, Wellington, 1993.
} 
prohibition. ${ }^{15}$ In relation to alcohol, all these writers shared a focus on the history of the temperance movement in the period up to 1920. For most historians the story of liquor control in New Zealand was largely seen as ending with the narrow defeat of prohibition in two referendums held within nine months in $1919 .{ }^{16}$

Stevan Eldred-Grigg's 1984 book on colonial vices also dealt solely with the period before 1920. However he took a broader approach than other historians, discussing not only the temperance movement but also other attitudes towards alcohol, its effects on society as a whole, and the role of other major players including the liquor industry and the government. ${ }^{17}$ Eldred-Grigg challenged what he saw as the predominant view that a stifling puritanism had subjugated colonial New Zealand society. ${ }^{18}$ In relation to liquor he concluded that many of the late-colonial controls were 'the work of moderates who wanted to regulate alcohol rather than puritans who wanted to prohibit it.. ${ }^{19}$ Yet his conclusion begs the very question that Bollinger set out to answer. Why did 'moderates' not only impose significant controls on the sale of liquor, such as limited licence numbers and six o'clock closing, but also maintain these controls for some 50 years?

One of the contentions of this thesis is that the controls were maintained in part because of an ongoing faith in the idea that restricting access to liquor will lead to less drinking, a central tenet of the availability theory. The theory belongs to what John Greenaway, writing about nineteenth and twentieth-century Britain, has called a 'restrictionist' approach to liquor control. "The state was regarded as having both the right and the duty to restrict and limit the consumption of strong drink wherever possible, and to wean consumers away from it. ${ }^{20}$ According to Greenaway, nineteenth-century restrictionist advocates proposed three main ways the state might do this: raising the price of liquor

\footnotetext{
15 Phillida Bunkle, 'The Origins of the Women's Movement in New Zealand: The Women's Christian T'emperance Union 1885-1895' in Beryl I lughes and Phillida Bunkle, eds, Women in New Zealand Society, Auckland, 1980, Charlotte Macdonald, cd., The Vote, the Pill and the Demon Drink: A History of Feminist Writing in New Zealand, 1869-1993, Wellington, 1993, Sarah Dalton, "The Pure in I leart: the New Zealand Women's Christian Temperance Union and Social Purity, 1885-1930', ML thesis, Victoria University of Wcllington, 1993, Sandra Concy, Standing in the Sunshine: A History of the New Zealand Women Since They W'an the V ote, Auckland, 1993.

${ }^{16}$ Gencral histories of New Zealand tend to add a postscript concerning the ending of six o'clock closing nearly 50 years later.

17 Stevan Fildred-Grigg, Pleasures of the Flest: Sex and Drmgs in Colomal New Zealand 1840-1915, Wellington, 1984.

18 Fildred-Grigg, Pleasures, pp. 1-2.

19) Eildred-Grigg, p. 245.

2010 John Greenaway, Drink and British Politics Since 1839: A Study in Policy-Making, Basingstoke and New York, 2003, p. 19. 'The term 'restrictionist' was earlier used by Brian Harrison, Drink and the Vitorians: The Temperance Question in England 1815-1872, London, 1971, p. 20 and elsewhere.
} 
through the tax system; reducing the hours of sale; and reducing the number of liquor outlets so 'the weak-minded would incur less temptation'. ${ }^{21}$ While the influence of restrictionist thinking in the industrialised world diminished in the middle decades of the twentieth century, it never faded entirely. From the 1970 s it underwent a revival, at least within the alcohol research community, and in the early years of the twenty-first century health researchers were prescribing remedies for society's alcohol-related ills that would have been familiar to restrictionists over a century earlier. For example the measures proposed in a 2003 publication sponsored by the World Health Organisation (WHO) included alcohol tax increases, restrictions on the hours and days of sale of liquor, and restrictions on outlet density. ${ }^{22}$ The persistence of restrictionist thinking is illustrated by the controversy surrounding the ending of standard opening hours for English pubs in November 2005. It was widely claimed that this reform would lead to more drinking and more alcohol abuse. ${ }^{23}$

The main theme of this present chapter is to place New Zealand within the international context of the rise and fall in restrictionist thinking. This international context is largely confined to the English-speaking world, primarily Britain, Ireland, North America and Australia, along with parts of continental Europe, particularly Scandinavia. Firstly, all these countries are among those in which alcoholic beverages were traditionally both common and socially accepted. ${ }^{24}$ Secondly, they represent a subset within this broader group in which opposition to the consumption of alcohol gained widespread popular support in the nineteenth century. Thirdly, they are countries that had some influence on thinking within New Zealand on alcohol issues through immigration, a shared cultural heritage (particularly the English language) and the trans-national sharing of ideas. Because it was a young colony in the late nineteenth century, New Zealand came under the sway of the restrictionist ideas that were increasingly in vogue throughout the English-speaking world. However the country developed its own distinctive form of liquor control that involved

21 Greenaway, Drink and British Politics, pp. 17-19.

22 Thomas Babor ct al, Aliohol: No Ordinary Comnzodity: Research and Public Poligy, Oxford, 2003, p. 270.

23 The provisions of the Licensing Act 2003 included allowing local flexibility regarding the opening hours of public houses rather than specifying set hours at a national level. Set closing hours in Fingland, Wales and Northern Ireland ended in November 2005; Jenny Booth, Sam Coates and Stewart Tendler, More than 1,000 places to serve alcohol 24 hours a day', 'Times Online', 23 November 2005, http://www.timesonlinc.co.uk/article/0.2-1886891.00.html, accessed 28 November 2005 .

24. Nithough the word 'alcohol' is derived from Irabic, alcoholic drinks have traditionally been prohibited in many Muslim societies. I lowever, although prohibitionists made occasional approving reference to injunctions against alcohol in the Qur'an (sce, for example, I anguard, June 1933, p. 15), Islam did not generally have a significant influence on restrictionist and prohibitionist thinking. 
restrictions imposed specifically on Maori, a heavy reliance on regular liquor polls, and the closure of most bars after six pm. This chapter charts the international tise of restrictionist ideas and their impact in New Zealand, their declining influence in the midtwentieth century, and their revival within the alcohol research community in the latter decades of the century. In doing so it provides an historical overview of liquor control in New Zealand. The chapter ends with a brief look at what some historians have written about the effect of liquor restrictions and provides an outline of subsequent chapters.

While a theme of this chapter is the degree of continuity over time, it should be noted that the main reasons for wanting to discourage the imbibing of alcoholic beverages have changed considerably since the mid-nineteenth century. Before the development of medical knowledge and social research into the harm done by alcohol, 'drunkenness' tended to be used as an overarching term for the various deleterious effects of liquor. ${ }^{25}$ Until the late nineteenth century, disapproval of excessive liquor consumption had therefore tended to be directed at drunkenness and the disorder and vices that were seen to accompany it. ${ }^{26}$ A century later the concerns of those in the alcohol research community wanting to restrict liquor sales were notably different from those of their precursors. Alcohol addiction was no longer seen as a moral weakness and it tended to be seen as a contributing factor rather than as a root cause of social ills. There was a general consensus among researchers on the harms caused by alcohol, including damage to individual health and that of unborn children, crime, anti-social behaviour, violence, drink-driving, and loss of productivity. ${ }^{27}$ Concerns of what might be called a moral nature were no longer seen as relevant and the religious notions that imbued many earlier liquor debates are notably absent.

However, although perceptions of alcohol-related harm changed dramatically over the course of some 150 years, restrictionist perceptions as to how to deal with this harm changed very little. Two concepts were central to the restrictionist philosophy: firstly, that the extent of harm will be reduced by reducing drinking in a society overall; and secondly, that reduced consumption can be best achieved by restricting access to alcohol. The reasons proposed as to why restricting the availability of alcohol might lead to less

\footnotetext{
25 I Jarrison, Drink and the Victorians, pp. 21-2.

26 Harrison, pp. 87-90.

${ }^{27}$ Ministry of Health and . I . IC, National Akiobol Strategy 2000-2003, Wellington, 2001, p. 4 and Prime Minister's Strategy Unit, Alcobol Harm Reduction Strategy for England, London, 2004, p. 7.
} 
drinking also remained reasonably consistent across time. Such restrictions were commonly justified by positing a relatively straightforward relationship between the availability of alcohol and how much of it was consumed. As an 1874 English temperance publication put it, 'so uniformly does the demand for strong drink increase with the supply, that the traffic if unrestrained, may be said to recognise no limits save those of anarchy and ruin'. ${ }^{28}$ This concept was more commonly expressed as the proposition that more opportunities for drinking meant more drunkenness. ${ }^{29}$ As a New Zealand MHR told parliament in 1881, 'there is unquestionably a fixed relationship between the number of public houses and the amount of drunkenness in the country. ${ }^{30}$ Some 65 years later thinking on the subject had changed little, as illustrated by the following statement by Crown Counsel to the New Zealand Royal Commission on Licensing in 1945: While it is difficult for the retailers of an article such as tea or sugar to persuade the public to increase their total purchase of that commodity, it might easily be possible for free competition to increase the total sales of intoxicating liquor to an alarming and injurious extent. ${ }^{31}$ The notion that the demand for liquor could be stimulated beyond some supposedly natural level by increased availability had by then become a standard assumption of New Zealand liquor policy. Thus the counsel told the Commission that the purpose of strict controls 'has been the creation of conditions under which persons in the trade could make an honest living by supplying a natural demand but without increasing that demand'. 32 The Commission agreed: 'The system should provide for meeting the demand which exists, but not for the stimulation of demand,' said its report. ${ }^{33}$

But how exactly did the greater availability of liquor stimulate demand? John Stuart Mill wrote in 1859 that the limitation in the number of English public houses was 'for the express purpose of rendering them more difficult of access, and diminishing the occasions of temptation'.34 This idea of temptation was central to restrictionist thinking.

\footnotetext{
28 Quoted by A.E. Dingle, The Rise and Fall of Temperance Economics, Monash Papers in Economic History no. 3, Melbourne, 1977, p. 8.

29. Indrew Barr, Drink: A Social History, J.ondon, 1998, p. 323.

${ }^{30}$ N/PD 1881, volume 38, p. 129

31 PRCL, p. 7715.

${ }^{32}$ PRCL, p. 7715.

${ }^{33}$ Royal Commission on licensing, p. 317.

${ }^{3}+$ John Stuart Mill, 'On I iberty' in Mary Warnock ed., Utititarianism, London, 1971, p. 234. Mill himself did not agree with the restrictions he was describing.
} 
'[M]ultiplied ale-houses are multiplied temptations,' declared British agriculturalist Arthur Young in $1798 .^{35}$ In 1834 a House of Commons Committee on Drunkenness condemned 'the increased number and force of the temptations... by the additional establishment of places at which intoxicating liquors are sold' ${ }^{36}$ In 1850 a select committee of the House of Lords similarly condemned the multiplication of public houses as increasing the temptations to excesss. ${ }^{37}$ English temperance campaigners would preach that a man could be persuaded to walk past two public houses but he could not be persuaded to walk past twenty. ${ }^{38}$ The temptation idea gained currency in New Zealand, where former Premier William Fox told the house in 1873 that moving a public house as little as a mile would 'reduce the people to a state of absolute sobriety - there is no temptation to drink whatsoever'. ${ }^{39}$ Another MHR stated in 1881 that 'drinking diminishes when temptations are removed'. The temptation idea lay behind more than just availability restrictions. For much of the twentieth century New Zealand law prohibited associating alcohol with a whole range of activities such as dancing, playing games, listening to music and eating. According to Jock Phillips, '[b]y segregating public drinking from other activities it had been hoped that the attractions of drinking would be reduced and its influence diminished'. In addition to entertainments, 'an attractive, pleasant-mannered barmaid...was considered to be one way in which publicans enticed numbers of men, particularly young men, into public bars'. ${ }^{41}$ As a Dunedin newspaper correspondent wrote in 1874: 'Surely intoxicating liquors... are seductive enough in themselves, and the root of evils great enough to satisfy the Archfiend himself, without adding woman, the great enchantress, to bewitch him. ${ }^{42}$ The 1910 ban on new barmaids was as much to protect men from temptation as to protect women from the unsavoury environment of the bar. ${ }^{43}$ By the late twentieth-century public health theorists were putting forward their own version of this temptation theory. They argued that if buying or consuming alcohol requires a higher degree of effort and planning, people may be less tempted to indulge; in

\footnotetext{
35 Quoted in Harrison, Drink and the L Titorians, p. 349.

36 (Quoted by Sidney and Beatrice Webb, The History of Liquor Licensing in England, London, 1903, pp. 125-6.

37 (Quoted by Joseph Rowntree and Arthur Sherwell, The Temperance Problem and Social Reform, London, 1899, p. 347.

38 Harrison, Dink and the T ictorians, p. 349.

39) N/PD 1873, p. 281.

40 J.O.C. Phillips, A Man's County? The Image of the Pakeha Male - a History, Auckland, 1987, p. 76.

41. Inthony (irigg, 'Prohibition and Women: The Preservation of an Ideal and a Myth', NZJH, vol. 17, no. 2, October 1983, p. 148.

42 Quoted by William Fox in N/PD 1874, volume XVI, p. 242. Sec also Eldred-Grigg, Pleasures, p. 192.

${ }^{43}$ Dalton, "The Pure in IIeart', p. 34 and Coney, Standing in the Sunshine, p. 128.
} 
economic parlance, it will raise their transaction costs. ${ }^{44}$ 'As availability decreases, its convenience to the consumer decreases, and thus physical availability has the potential to influence the consumer's demand for alcoholic beverages. ${ }^{45}$ Others argued that liquor outlets have an advertising effect - an open bar is an invitation to custom. With fewer bars there will be fewer such invitations. ${ }^{46}$ As the above quote from Mill shows, both these arguments would have been familiar to nineteenth-century restrictionists.

\section{The Historical Background to Restrictionist Thinking}

Restrictionist approaches to liquor in the English-speaking world owe much to the popularisation of distilled spirits in the seventeenth and eighteenth centuries. In 1751 William Hogarth published his famous print Gin Lane, a commentary on the degradations of the English 'gin craze'. The print was published with a lesser-known companion titled Beer Street, depicting healthy and prosperous revellers at a London tavern. The contrast was a deliberate one on the part of the artist. ${ }^{47}$ In Europe beer and wine were perceived as something traditional and even healthy while the availability of distilled spirits as affordable and popular drinks was seen as something new and dangerous. ${ }^{48}$ In France and Russia there were attempts to discourage the drinking of brandy and vodka in the $1650 \mathrm{~s}^{4}{ }^{4}$ In Britain between 1729 and 1760 the government tried to suppress the gin trade it had deliberately promoted in the $1690 \mathrm{~s}$, even briefly experimenting with prohibition. ${ }^{50}$ The extent of gin drinking was eventually reduced with the help of taxation and a temporary ban on stills, but distilled spirits in the form of brandy, whisky, gin, rum and vodka remained popular internationally and continued to cause problems, particularly in the prosperous English-speaking world. ${ }^{51}$ In the United States a grain glut made it more economic to use grain in distilling than to transport it to distant markets, leading to an abundance of cheap whiskey for much of the nineteenth century. As a result

\footnotetext{
H Christinc Godfrcy and Alan Naynard, 'An cconomic theory of alcohol consumption and abuse', in Douglas Chaudron and Idrian Wilkinson, eds, Theories on Alcoholism, 'T'oronto, 1988, p. 420.

45 Babor ct al, Aliabol: No Ordinary Commodity, p. 118.

${ }^{46}$ Godfrey and Maynard, 'An cconomic theory of alcohol consumption and abusc', p. 420.

${ }^{47}$ Jean-Charles Sournia, A History of Akoholism, Oxford, 1990, p. 22 and Patrick Dillon, The Much-lamented Death of Madam Geneva: The Eighteenth-ientury Gin Craze, London, 2002, pp. 246-8, 162-3 (illustrations).

48 Dillon, Madam Geneva, p. 4.

+9. Dillon, pp. 3-4.

${ }^{50}$ Dillon, especially Chapters 1, 5, 8-12,14, 15 .

${ }^{51}$ Dillon, Madam Geneva, pp. 261-4, 279-293. 'The increased price and reduced consumption of spirits after 1850 was also assisted by a grain shortage.
} 
comparatively little beer and wine was drunk in North America until the latter decades of the century. ${ }^{52}$

The rise of spirits-drinking made it a target for early temperance reformers. Some tried to encourage the drinking of wine and beer rather than 'ardent spirits'. ${ }^{53}$ The early decades of the nineteenth century saw the rise of the first organised temperance movements in North America and Britain. Unlike later temperance organisations they tended to direct their efforts towards discouraging the consumption of spirits while ignoring or even promoting the drinking of beer and wine. ${ }^{54}$ The first American temperance societies were solely concerned with the effects of 'ardent spirits', and a New Zealand Temperance Society formed by colonists at Kororareka in 1835 aimed solely at discouraging spiritsdrinking. ${ }^{55}$ In the English-speaking world, wine was perceived as a drink of the upper classes and beer was seen as an important source of nutrition for workers. Alcohol acted as a preservative, enabling the food value of processed grains to be stored for much longer periods than if they were transformed into alternatives such as bread. ${ }^{56}$ An additional virtue of beer was that many harmful organisms were destroyed in the brewing process. This generally made it safer to drink than water, which was frequently polluted. Most inhabitants of London and New York, for example, did not acquire a safe water supply and a reliable sewage system until the late nineteenth century. ${ }^{57}$ Before the development of innovations such as piped sewage, pressurised water mains and flush toilets, colonial New Zealand cities were 'notorious cesspools'. ${ }^{58}$ An immigrant to Dunedin in the 1860 s told a newspaper reporter that, while he had drunk water at 'home', he had since been obliged to give it up and drink colonial ale instead. ${ }^{59}$ Most Dunedin water was undrinkable and there was no general public water supply until the 1870 s. ${ }^{61}$

\footnotetext{
52 Ian Tyrrell, Sobering Up: Fram Temperance to Probilition in Antebellum America, 1800-1860, Connccticut, 1979, pp. 25-6, 1367 and W. J. Rorobaugh, 'Alcohol, Consumption of, per Capita (U.S.)' in Jack Blocker Jr., David Fahey and Ian 'Tyrrell, eds., Aliobol and Temperance in Modern History: an International Engclopedia, Santa Barbara, 2003, p. 23.

53 Sournia, A History of Alcaholism, p. 22 and Barr, Dimk, pp. 288-9.

it Jack S. Blocker Jr., American Temperance Movements: Cycles of Reform, Boston, 1989, pp. 8-12, Barr, Drink, pp. 289-291, Sourna, A History of Alcoholism, p. 22, I larrison, Drink and the Victorians, pp. 87-106.

55 Tyrrell, Sobering Up, pp. 136-7 and McKimmey, 'The Temperance Movement in New Zealand', pp. 51-3. Viticulturalist James Busby was a founding member of the New Zealand society.

56 Barr, Drink, pp. 249-51 and Eildred-Grigg, Pleasures, pp. 59-60.

${ }_{57}$ Blocker, American Temperance Movements, p. 35, Barr, Drink, pp. 255-7, I Iarrison, Drink and the Vitorians, pp. 37-39. The pupils of Lton and Winchester schools drank beer with their meals until the 1870 s.

58 James Belich, Paradise Reforged: A History of the New Zealanders from the 1880 s to the year 2000, Auckland, 2001, p. 174.

59) Cited by Pamela Wood, Dirt: Filth and Decay in a New World Arcadia, Auckland, 2005, p. 71.

60 Wood, Dirt, pp. 71-3.
} 
Alternative sources of refreshment such as tea were commonly frowned upon in the nineteenth century because they were perceived as having limited food value compared with beer. ${ }^{61}$ Milk was expensive and often harboured disease. ${ }^{62}$

Despite the perceived benefits of beer in particular, the temperance and prohibition movement increasingly began to shun all forms of alcoholic drink in the middle decades of the century. Part of the impetus for this shift in emphasis came from the development of the disease concept of alcoholism which held that alcohol addiction was a disease that could be prevented only by total abstinence. This early disease concept conceived of alcohol addiction as something to which all drinkers, rather than a predisposed minority, were susceptible. It thus became a central plank of temperance ideology that even moderate drinking was a danger; all were at risk from the scourge of alcoholism. ${ }^{63}$ Because of the international character of the movement, temperance gradually became synonymous with prohibition throughout much of the English-speaking world. ${ }^{64}$ The focus was initially on reforming individuals, and total abstinence societies spread throughout Britain, North America, Ireland and New Zealand. ${ }^{65}$ Some temperance campaigners also tried to impose abstinence through political action. In the 1850 s the sale of liquor was outlawed in 13 American states and territories. ${ }^{6.6}$

The American liquor bans were soon overturned, but this proved to be only a temporary setback in the rising tide of anti-alcohol sentiment. While few supported prohibition, temperance ideas made their mark on the public at large, which was made increasingly aware of the dangers of alcohol. A new wave of temperance sentiment was generated in America and beyond by the growing voice of women. ${ }^{67}$ The second half of the nineteenth century saw both a reduction in the importance of liquor as a food source and an increasing awareness of the detrimental health effects of all forms of alcohol. From the 1830 s temperance campaigners questioned the nutritional value of beer, whose

\footnotetext{
6 Barr, Drink, pp. 250-1.

${ }_{62}$ Harrison, Drink and the Vittorians, p. 38, Barr, Drink, pp. 264-6.

6.3 Nick I Ieather and Ian Robertson, Problem Drinking, 3rd edition, Oxford, 1997, pp. 18-23 and Blocker, American Temperance Movements, pp. 16-22. The actual term 'alcoholism' was not coined until the $1850 \mathrm{~s}$.

af The international character of the temperance movement is outlined in Chapter 2.

65 I Iaydon, An Inebriated History of Britain, London, 2005, pp. 207-8, Eldred-Girigg, pp. 178-9 and Dingle, Temperance Economiss, p. 2.

66 Tyrrcll, Sobering Up, p. 12.

${ }_{67}$ Blocker, American Temperance Movements, pp. 61-94.
} 
importance as a source of food did in fact decline during the century. ${ }^{68}$ Improved preservation, storage, transport and refrigeration made other foods more easily accessible at a time when new brewing techniques produced beers that were lighter and lower in calorific value. Non-alcoholic alternative refreshments such as cordials and aerated drinks became commonplace and affordable and tea became increasingly popular. ${ }^{(9)}$ Water and milk supplies were made safer. In addition, scientific research from the 1860 s onwards increasingly demonstrated the detrimental effects of alcohol for health. Alcohol did not warm the body as many believed, and it was found to be a depressant rather than a stimulant. $^{70}$ Subsequent studies found that alcohol affected memory, co-ordination and the capacity for physical labour. ${ }^{71}$ By the turn of the century scientists were throwing new light on the role of alcohol in insanity, disease, and on the effect of drinking by pregnant women. $^{72}$ These discoveries had a profound effect on the thinking of the scientific community, the medical profession, and an increasingly science-literate public. ${ }^{73}$ Research by insurance companies in Europe and the United States led some to offer lower premiums to abstainers. ${ }^{74}$ In New Zealand the Government Insurance Department set up a Temperance Section to lure non-drinking customers with lower premiums. ${ }^{75}$

The rise of what A.E. Dingle has dubbed 'temperance economics' was also a factor in the swing against alcohol. ${ }^{76}$ Temperance campaigners were concerned about the social effects of liquor, especially its role in crime and disorder among the lower orders. ${ }^{77}$ These concerns were increasingly supplemented by claims that liquor was a cause of poverty and that the consumer derived no benefit from its purchase. Extending this argument to a national level led to the conclusion that all expenditure on drink was wasteful; compiling the national 'drink bill' each year became a standard activity for prohibition campaigners. Furthermore the consumption and manufacture of alcohol had a number of indirect costs including absenteeism ('Saint Monday'), reduced industrial efficiency, unproductive use of

\footnotetext{
6. I Jarrison, Drink and the I ictorians, pp. 121-2, I Jaydon, An Inebriated History, pp. 206.

6) F:Idred-Grigg, Pleasures, pp. 211-212.

${ }^{70}$ James Timberlake, Probilition and the Progressive Movement 1900-1920, Cambridge, Massachusetts, 1963, pp. 40-1.

${ }_{11}$ Timberlake, Probibition and the Progressive Motement, pp. 41-2.

72 Greenaway, Drink and British Politics, pp. 54-5 and Timberlake, Probilition and the Progressive Movement, pp. 43-5.

${ }^{73}$ Timberlake, Probilition and the Progressive Movement, pp. 45-7, 55-7.

7t Timberlake, pp. 53-4.

${ }^{75}$ The Probilitionist and Direct Veto Advocate, 14 July 1906, p. 8.

${ }_{76}$ Dinglc, Temperance Economiss.

77 Sournia, A History of Aliobolism, p. 20.
} 
raw materials, crime, pauperism, sickness and social distress. While these arguments were not new, Dingle credited their theoretical exposition to William Hoyle, a cotton manufacturer whose major work on the subject sold over 100,000 copies in Britain in the 1870s. His arguments were given a boost by the onset of the 'great depression' in the 1880 s, a phenomenon economists struggled to explain. Hoyle's explanation was that household expenditure wasted on drink resulted in under-consumption of other items. Diverting household expenditure from liquor to more productive goods was therefore required to stimulate the economy. These temperance economic views were criticised for ignoring the food value of alcoholic beverages and the pleasure derived from their consumption. ${ }^{78}$ Others such as Charles Dickens condemned the 'monstrous doctrine which sets down as the consequences of Drunkenness, fifty thousand miseries which are...the wretched causes of it'. ${ }^{79}$ However the critics of temperance economics were forced to concede many of its main points, including the social costs and industrial inefficiency engendered by drink. ${ }^{80}$ Empirical research by the likes of Charles Booth and Seebohm Rowntree showed that expenditure on drink was one of a number of factors that contributed to poverty. ${ }^{81}$

While the work of early social researchers provided some support for temperance economic views, it also appeared to show that poverty resulted from broader social conditions rather than individual failings such as idleness or intemperance. ${ }^{82}$ Popularisation of these findings helped accelerate changing perceptions regarding the role of government. In Britain the move towards a more interventionist approach was reflected in the regulation of the liquor trade. Under the traditional English licensing system, nominally independent assessors such as magistrates would determine the number of outlets needed in each district and issue licences accordingly. ${ }^{83}$ According to Greenaway, supporters of the traditional system of regulation tended to see it primarily as raising revenue and preventing disorder and the illegal adulteration of liquor rather than as promoting temperance. Some were 'moral suasionists' who advocated promoting

\footnotetext{
${ }^{78}$ Dingle, Temperance Economics, pp. 2-15.

79 Quoted in I Jarrison, Drink and the I kitorians, p. 355. Emphasis in original.

80 Dingle, Temperance Economiss, pp, 11-12.

81 Dingle, pp. 22-3.

82 Grecnaway, Drink and British Politics, p. 56.

${ }_{83} \mathrm{~W}$ ebb, History of Liquor Liensing in England, p. 6.
} 
temperance through education rather than legislation. ${ }^{84}$ In contrast free-trade advocates criticised the arbitrary way in which Magistrates could grant or withhold licences at their whim, advantaging some with a virtual monopoly and removing the livelihood of others. Free-traders argued that the system was prone to corruption, with Magistrates subject to undue influence by the brewers who owned a significant proportion of public houses. Liquor smuggling and vices such as drunkenness would be reduced by relatively unrestricted trade in liquor, they claimed. ${ }^{85}$ Although free licensing advocates achieved a number of victories between the 1820 s and 1860 s, by 1870 'both the purely moral suasionist and the free-licensing model of liquor control had lost much of their appeal and power. ${ }^{86}$ Restrictionist ideas became more influential as temperance sentiment increased during the century. There was a 'striking retreat' from free trade as liberalisation measures such as the 1830 Beer Act were gradually reversed and restrictions on hours of sale were tightened. ${ }^{87}$ These controls were further tightened around the turn of the century as the changing intellectual climate resulted in a shift in the emphasis of social intervention from reforming individuals to reforming society. ${ }^{88}$

The British experience of greater government intervention in liquor availability was shared by several countries including New Zealand. ${ }^{82}$ Until the abolition of the provinces in 1876, each province had different liquor laws and there was 'little real control' over the sale of alcohol. disorder and a desire to protect traditional tribal society from the ravages of alcohol. An 1847 Ordinance outlawed the supply of spirits to Maori in proclaimed districts, although such restrictions were allegedly widely ignored. ${ }^{11}$ Restrictions on Maori access to alcohol continued to be imposed with the support of some influential Maori and in 1884 the King Country was proclaimed a dry area. ${ }^{92}$

\footnotetext{
$8+$ Greenaway, Drink and British Politics, pp. 9-13.

85 I Jarrison, Drink and the Victorians, pp. 64-5.

Bo Greenaway, Drink and British Politits, p. 27.

${ }_{87}$ Harrison, Drink and the Vittorians, p. 251, Grecnaway, Drink and British Politics, p. 34.

s8 Grecnaway, Drink and British Politics, p. 54.

${ }^{80}$ See, for example, Craig I leron, Booze: a Distilled History, Toronto, 2003, pp. 131-185, Elizabeth Malcolm, Ireland Sober, Ireland Free: Drink and Temperance in Nineteenth-Centuy Ireland, Dublin, 1986, pp. 206-266, Milton Lewis, A Rum State: Alcohol and State Policy in Australia, Canberra, 1992, pp. 49-71.

90 'The Justice Department, quoted in Royal Commission on the Sale of I iquor, p. 21.

91 Eldred-Grigg, Pleasures, pp, 67, 85-88.

92 Eldred-Grigg, pp. 193-6.
} 
There was little evidence from official statistics of a high incidence of Maori drunkenness but the same cannot be said for Pakeha. As Miles Fairburn has shown, the preponderance of young, single males engaged in sporadic but demanding work resulted in a drinking binge that outdid any other period in New Zealand history. In the 1850 s and 1860 s the rate of consumption of spirits in particular was extraordinarily high and the rate of convictions for drunkenness far surpassed that for England and Wales. ${ }^{93}$ A move to increase the controls on the supply of liquor to Pakeha began with the 1873 Licensing Act, which set up local licensing courts to issue licences. The courts were required to apply a need test - to adjudge whether in their opinion 'there is necessity for the public house or other establishment for the sale of spirituous liquors. ${ }^{94}$ A new Licensing Act in 1881 was ostensibly a consolidation of existing statutes, repealing 49 Acts and Provincial Ordinances relating to liquor following the abolition of the provinces. ${ }^{95}$ However in practice it extended to the whole country restrictions that had hitherto applied to only parts of it. For example Sunday trading was largely abolished although it had previously been allowed in Nelson and Marlborough. ${ }^{96}$ Once an interventionist Liberal government came to power in 1890 the state further strengthened its hold over liquor sales and the country began to develop its own distinctive controls. From 1894 regular polls could determine if the number of outlets would be reduced in a region or eliminated altogether. Maori access to alcohol was further curtailed. ${ }^{97}$ The legal hours of sale were progressively reduced and the legal drinking age was raised to $21 .^{98}$ Music, dancing and other entertainments were banned from pubs, and no new barmaids were allowed after $1910 .{ }^{9}$

Ironically these restrictions came at a time when New Zealanders 'were relatively moderate drinkers.' ${ }^{100}$ By 1890 the drunkenness rate had collapsed to a fraction of what it had been in earlier decades. ${ }^{101}$ New Zealanders drank a third as much beer per head in the

\footnotetext{
${ }^{23}$ Miles Fairburn, The Ideal Society and its Enemies, Iuckland, 1989, pp. 206-8.

${ }^{24}$ I icensing . Ict, New Zealand Statutes 1873 , p. 332.

95 N'/PD 1881, volume 38, p. 105.

9 N/PI) 1881, volume 38, p. 109

${ }_{97}$ Bollinger, 1967, p. 104 and Eldred-Grigg, Pleasures, pp. 193-6

98 An exception allowing bona fide travelers to be served alcohol on Sundays was removed in 1904, L. II. Southwick, Alan Dormer, G.R. Halford, The Liquor Laws of New Zealand, Wellington, 1983, p. 3.

99 A summary of these changes is provided by Southwick et al, pp. 2-4. Female licence-holders and close female relative of licence-holders were still allowed to work behind the bar, as were barmaids who had been registered before 1913, Coney, Standing in the Sunshine, p. 128.

100 Eildred-Grigg, Pleasures, p. 209.

${ }^{101}$ Fairburn, Ideal Society, pp. 206-7.
} 
1890s as their British counterparts. Per capita spirits consumption in New Zealand was two-thirds the rate in Victoria, New South Wales and Britain. New Zealanders drank less beer and much less wine than residents of the Australian states. ${ }^{102}$ Reasons for the reduction in drinking and drunkenness in the 1870 s and 1880 s are complex. The 1880 s depression undoubtedly affected consumption. The proportion of male immigrants in the population declined - a group notorious for drinking and drunkenness. ${ }^{103}$ The price of beer and tea fell relative to spirits. Clean water became freely available, and carbonated drinks and cordials became popular. ${ }^{104}$ Short-term extractive industries such as mining and timber milling were gradually replaced in importance by more permanent industries such as agriculture and manufacturing. Formerly mobile men settled down and formed families. The towns and cities grew, as did the number of alternative recreational attractions to the pub. Yet perversely, as drinking and drunkenness reduced, efforts to control them increased in their intensity. One reason lies in the example being set overseas. In other countries 'a strong hand is being used in reference to the sale of spirits and intoxicating liquors', the Colonial Secretary told parliament when introducing the Licensing Bill in $1881 .^{105}$

The first half of the twentieth century was the heyday of the restrictionist approach to alcohol in North America, Australasia, and much of Europe, where a broad consensus had emerged on the desirability of reforms to restrict drinking. In America even the business community, a sector not always inclined to support state intervention, saw merit in restricting the availability of alcohol in the interests of industrial safety and efficiency. ${ }^{106}$ 'National efficiency' was an increasing concern, particularly in Britain where there had been much hand-wringing over military incompetence during the Boer War. ${ }^{107}$ Some intellectuals questioned liberal values that emphasised individual freedom, and instead advocated a more scientific and businesslike approach to government to maximise the efficient use of resources - especially human resources through improved health,

\footnotetext{
102 1.F. Dingle, "The 'Truly Magnificent 'Thirst: In Historical Survey of Australian Drinking Habits", Historical Studies, vol. 15 no. 75 , October 1980, p. 242-3, and G.T. Bloomficld, New Zealand: A Handbook of Historizal Statistics, Massachusctts, 1984, p. 120.

103 Fairburn, Ideal Society, pp. 214-15. The over-representation of immigrants in the drunkenness statistics was regularly mentioned in the NZOYB.

${ }^{10+}$ Fildred-Grigg, Pleasures, p. 212.

105 N/PD 1881, volume 38, p. 51.

106 Timberlakc, Prohibition and the Progressive Movement, pp. 67-8.

107 G. R. Searle, The Quest for National Efficieng: A Study in British Politics and Political Thought, 1899-1914, Los Angeles, 1971.
} 
education and breeding, all areas in which excessive drinking was seen as a barrier. ${ }^{108}$ New Zealand temperance advocates began to emphasise national efficiency in addition to (or instead of) moral and social factors, arguing that alcohol was wasteful both through the damage it did to individuals and through the way it misallocated economic resources away from more productive areas. ${ }^{109}$ With outbreak of war in 1914, national efficiency became more than just an intellectual movement - it was seen by many as vital for national survival. The debate on liquor was re-couched in terms of the extent to which its production and consumption hindered the war effort. ${ }^{110}$ The result was a further tightening of liquor restrictions in many countries including New Zealand, where business representatives lobbied the government to curb the availability of alcohol. ${ }^{111}$ The war gave the restrictionist campaign a momentum which led to supposedly temporary restrictions being made permanent after it ended, and the prohibition of liquor sales altogether in several countries including the United States. In New Zealand the 'temporary' wartime imposition of six o'clock bar closing was made permanent in 1918. As will be seen, the following year the country came within a hair's breadth of imposing a total ban on liquor sales.

The growth in popular support for dealing with alcohol misuse as a social issue rather than as an individual affliction led to a decline in the influence of the concept of alcoholism as a disease. The temperance movement had largely abandoned attempts to reform individuals in favour of political action. By the 1930 s it was almost as though the concept of alcohol addiction as a disease had never existed. ${ }^{112}$ However there was a revival of the disease concept after the repeal of prohibition, as Americans 'were tired of the emotionalism and extremity of views which characterized the battle between the wets and drys and were only likely to respond to an approach which seemed to convey the objectivity and rationality of science. ${ }^{113}$ Such an approach came from the Yale Centre for Alcohol Studies founded in 1940, headed by E.M. Jellinek. Jellinek became a leading

\footnotetext{
108 Scarle, Quest for National Efficieng, cspecially pp. 54-106.

${ }^{109}$ NZPD 1916 , vol.177, pp. 278-9.

110 Greenaway, Drink and British Politics, p. 91, Heron, Booze, p. 178.

111 Auckland Star, 20 July 1917, p. 3, NZPD 1917, vol 180, p. 218, Rev. J. Cocker and J. Malton Murray eds., Temperance and Probibition in New Zealand, Wellington, 1930, pp. 127-129, hereafter referred to as Cocker and Murray.

112 Heather and Robertson, Problem Drinking, p. 27. They note that this change came about despite the growth of inebriate asylums.

113 Ileather and Robertson, p. 28.
} 
proponent of what was labelled 'a new approach to alcoholism' through his work with Yale and later with WHO. ${ }^{114}$

Nick Heather and Ian Robertson have claimed that the new disease concept was formulated to help make it acceptable in the post-prohibition environment and avoid reigniting controversy. ${ }^{115}$ Thus, unlike the earlier conception of alcoholism, it was argued that only a few predisposed individuals were susceptible to the disease while the majority could drink moderately without succumbing. ${ }^{116}$ Working with a variety of organisations, including the recently-founded Alcoholics Anonymous (AA), the Yale centre popularised the new approach which returned to an emphasis on reforming vulnerable individuals. ${ }^{117}$ The disease concept continued to exert a strong influence in America in subsequent decades, thanks largely to the work of $\mathrm{AA}$, and was also influential in other countries. ${ }^{118}$ In New Zealand, while the report of the 1945 Royal Commission on Licensing made no mention of alcoholism and its treatment, the report of the 1974 Royal Commission on the Sale of Liquor devoted nearly 14 of its 365 pages to the subject. ${ }^{119}$

The notion that alcoholism was a disease that affected a select group who were distinct from social drinkers seemed to undermine the traditional temperance view that even moderate drinkers may be taking the first steps down a slippery slope to ruin. ${ }^{120}$ The new thinking therefore appealed to proponents of a less restrictive approach to liquor. For example Bollinger, New Zealand's best-known post-war advocate for more liberal liquor laws, wrote in 1959 that ' $[t]$ he advances that have made it possible to treat alcoholism as a disease weaken the arguments for putting artificial hurdles in the way of the non-alcoholic majority's access to reasonable quantities of alcohol'. ${ }^{121}$ Bollinger could be classified as a supporter of what has been dubbed the social integration or socio-cultural model that advocated a more 'European' approach to drinking. This model emerged in the light of

\footnotetext{
11+ Sournia, A History of Alcohalism, p. 149, Barr, Drinke, p. 314, Heather and Robertson, Problem Drinking, pp. $28-9$.

115 I Ieather and Robertion, Problem Drinking, p. 30.

116 Blocker, American Temperance Movements, pp. 132-3.

117 Heather and Robertson, Problem Drinking, p. 30.

118 Heron, Booze, pp. 351-370, Barr, Drink, p. 314, Heather and Robertson, Problem Drinking, pp. 31-40.

119 Royal Commission to Inquire Into and Report Upon the Sale of Liquor in New Zealand, The Sale of Liquor in New Zealand, Wellington, 1974, pp. 288-302, hereafter Royal Commission on the Sale of I iquor. There is no mention of 'alcoholism' in the index of the 1945 royal commission's report, or in the section on the 'mischiefs' associated with alcohol.

${ }^{120}$ Heron, Booze, p. 333.

121 Bollinger, 1959, p. 163.
} 
the failure of prohibition in the United States, although did not become influential until the post-war period. Its supporters pointed to the different attitudes to alcohol held by different cultural groups, claiming that the healthiest drinking habits and attitudes were found in those societies and cultures in which moderate drinking was integrated into everyday life. In contrast, those raised in a censorious environment towards alcohol were allegedly driven by guilt into unhealthy drinking habits. Restrictive approaches were therefore claimed to act against the adoption of healthy drinking styles. ${ }^{122}$ In New Zealand a small minority had long supported a social integration approach to liquor control. Evidence from the 1945 Royal Commission on Licensing indicates that at least some of those who had travelled or lived abroad held the view that integrating drinking into other aspects of life was desirable. Where liquor is plentiful...it is not made so much of, claimed one well-travelled witness. ${ }^{123}$ Bollinger argued that in many respects the existing licensing law, 'seems designed to give alcohol an undue significance in the human mind, and to foster an hysterical attitude towards it highly conducive to the worst possible results'. ${ }^{124}$

In New Zealand, as in other countries, the push for more liberal licensing laws eventually resulted in a loosening of the restrictionist grip on policy. In 1962 the Minister of Justice questioned the idea that more drinking facilities meant greater consumption. ${ }^{125}$ In 1967 some cast doubt on the notion that expenditure on drink would expand to fit the additional hours available if ten o'clock closing resumed. 'There is an economic limit to the amount the average chap can drink,' wrote one newspaper columnist, reflecting the views of a number of protagonists in the debate. ${ }^{126}$ Admittedly some still argued that, with temptation placed in their way through more convenient hours of sale, people would divert an increasing proportion of their discretionary income into buying alcoholic beverages; a Tauranga temperance group wrote to the Prime Minister about 'the increase in liquor consumption which must inevitably arise from increased leisure hours licensed for drinking' and a Dunedin magistrate told a forum on hotel hours that 'extended hours

\footnotetext{
122 Wolfyang Schmidt, 'Cirrhosis and Alcohol Consumption: an Fpidemiological Perspective', in Griffith Edwards and Marcus Grant, eds., Alcobolism: New Knowledge and Responses, London, 1977, p. 39; I Ieron, Booze, p. 333; Thomas Plaut, Aliobol Problems: A Report to the Nation by the Cooperative Commission on the Study of Aliobolism, New York, 1967, pp. 48-9, 119-142; David I lanson, Preventing Alcohol Abuse: Akohol, Culture and Control, Westport, Connecticut, 1995.

123 PRCI, p. 1441. See also pp. 1435-1444, 1903-10, 4618, 5607, 5616, 5621-5655, 6940.

124 Bollinger, 1959 , p. 75

125 Stacc, p. 422.

126 Anckland Star, 9 September 1967, p. 7.
} 
would mean spending more money. ${ }^{127}$ However the decisive 1967 referendum vote against six o'clock closing showed that such restrictionist views were no longer fashionable. The changing attitudes in the 1960 s resulted in significant legal reforms. A few licensed restaurants were allowed, barmaids were readmitted to pubs, some entertainments were allowed in bars, and six o'clock closing ended. Continued restrictions on new outlets in face of rising demand for alcohol resulted in large pubs that were given the derogatory label 'booze barn'. However booze barns went into decline after 1977 law changes increased the ability of sports and other clubs to sell alcohol, made restaurant licences easier to obtain, and allowed customers to bring their own alcohol to many eating-places. ${ }^{128}$ These reforms accelerated changes in New Zealanders' social habits, as alcohol was increasingly consumed in clubs and restaurants rather than in bars.

The New Zealand trend towards easier access to alcohol reflected changes throughout the industrialised world. But many in the burgeoning alcohol research community opposed the move towards more liberal licensing laws. They pointed to the growing body of evidence that discredited the disease concept of alcoholism, which was attacked as being inadequately defined and lacking robust empirical support. Influenced by the growing discipline of sociology they drew attention to the negative effects of alcohol - such as drink-driving, health problems and domestic violence - which extended far beyond a small group of alcoholics and their families. ${ }^{129}$ Many alcohol researchers therefore called for a return to treating alcohol abuse as a societal rather than an individual problem, by reducing the consumption of the entire population rather than targeting problem drinkers. They noted that countries such as France with open attitudes towards liquor had high levels of consumption and correspondingly high death rates from alcohol-related conditions. The liberalisation of liquor laws in other industrialised countries seemed to have had similar consequences, while alcohol treatment programmes were proving expensive and disappointing in their results. ${ }^{130}$

\footnotetext{
127 Letter from Tauranga Seventh Day Adventist Temperance Society dated 29 May 1967, quoted by Geoffrey Biggs, 'Some Political and Social Implications of Later Closing, MA thesis in l'olitical Science, Victoria University of Wellington, 1970, p. 4, Otago Daily Times, 6 September 1967,p. 1.

128 . These changes are discussed in detail in Chapter 4.

129 Barr, Drimk, p. 314. A thorough account of the disease concept, including its historical development and the evidence against it, is provided by Heather and Robertson in Problem Drinking.

${ }^{130}$ Fric Single, 'The availability theory of alcohol-related problems' in Chaudron and Wilkinson, Thearies on Aloobolism, $\mathrm{p}$. 330.
} 
The new thinking caught on. According to Betsy Thom, 'by the end of the 1970 s, there had been a crucial 'frame shift' in alcohol policy towards a general populations, prevention oriented approach'. ${ }^{131}$ In addition to the influence of sociology, much of the impetus for this frame shift came from Finland and Canada through the Addiction Research Foundation of Ontario and the Finnish Foundation for Alcohol Studies. In a series of publications in collaboration with WHO - beginning in 1975 with Alcohol Control Policies in the Public Health Perspective - these organisations helped popularise in the international research community a return to a public health approach to controlling alcohol abuse. ${ }^{132}$ Central to the measures advocated by public health theorists were restrictions on the availability of alcohol in order to reduce drinking and alcohol misuse. To quote a recent WHO-sponsored publication, '[r]eductions in the hours and days of sale, numbers of alcohol outlets, and restrictions on access to alcohol, are associated with reductions in both alcohol use and alcohol-related problems'. ${ }^{133}$ This emphasis on making liquor less easily available to consumers resulted in the label 'availability theory' commonly being applied to what was essentially the old restrictionist model dressed up in new clothes. ${ }^{134}$

During the 1980s many within New Zealand's alcohol research community became advocates for the restrictionist public health approach. For example Auckland University's Alcohol Research Unit published a series of four monographs titled From a Public Health Perspective which discussed issues such as alcohol availability and taxation policy. ${ }^{135}$ However the mid-1980s was not a fruitful time to propose retaining or increasing regulation in New Zealand. The fourth Labour Government elected in 1984 enthusiastically embraced economic liberalism by floating the dollar, reducing tariffs, deregulating business and finance, slashing agricultural and other subsidies and selling government enterprises. Social liberals dominated Parliament at the time, as shown by the passing of the Homosexual Law Reform Act in 1986. It is therefore unsurprising that the liquor laws were included in the drive for deregulation. In 1985 the government established a Working Party on Liquor which recommended a radical overhaul of liquor

\footnotetext{
131 Betsy Thom, Dealing with Drink - Aliobol and Social Policy: From Treatment to Management, London, 1999, p. 110.

132 Babor et al, Alcobol: No Ordinary Commodity, p. 1.

133 Babor et al, p. 133.

134 Singlc, 'The availability theory of alcohol-related problems' p. 325.

135 The four publications were: Sally Casswell and 1 iz Stewart, From a Public Health Perspective; Availability of Aliohol in Nen Zealand; Toni Ashton and Sally Casswell, From a Public Health Perspective; Alcohol Pricing Policy in New Zealand, Sally Casswell and Carey Martin, From a Public Health Perspective; Shaping Attitudes Tomards Alcobol in New Zealand; Liz Stewart and Sally Casswell, From a Public Health Perspective; Control of Drinking on Liensed Premises in New Zealand, all Auckland, 1986.
} 
policy when it reported the following year. The result was the 1989 Sale of Liquor Act that completely rewrote the legislative framework rather than making the piecemeal adjustments that had characterised most previous change. To contemporary journalists the changes under the new Act appeared minor in the context of other radical social and economic changes. Media coverage said little about the importance of the reforms and instead focused on what the Act did not do. ${ }^{136}$ It did not lower the drinking age, remove restrictions on Sunday sales or allow beer and spirits to be sold in supermarkets and grocery stores. These omissions were criticised by editorial writers, with one describing the Act as 'disappointing legislation which refuses to acknowledge the countries [sic] mood for progressive change. ${ }^{3.37}$ Such criticisms overlooked the fact that the Act overthrew almost every principle that had been the foundation of liquor legislation for over 100 years, including the severe rationing of licences, the link between the sale of alcohol and the provision of accommodation, uniform opening hours, and the regular submission of decisions relating to alcohol to popular vote.

In addition to being largely ignored in this legislative reform, by the 1990 s restrictionists were losing ground within New Zealand's health and research community. An alternative labelled 'harm minimisation', which focused on 'reducing the adverse consequences of drinking without necessarily reducing drinking per se', gained increasing favour. ${ }^{138}$ While advocates of harm minimisation generally agreed that the incidence of alcohol related problems tends to fluctuate with average consumption, they noted that rates of individual problems do not necessarily fluctuate simultaneously, that different subgroups have different drinking habits, which may imply a variety of approaches, and that the pattern of drinking is an important influence on negative outcomes. ${ }^{139}$ They criticised the emphasis on average consumption levels under the public health approach as ignoring harmful drinking behaviour, such as binge drinking among supposedly moderate drinkers. ${ }^{140}$ Instead they proposed measures such as combating drink-driving, encouraging server responsibility, standard drink labelling, and creating safer bars. ${ }^{141}$ While restrictionism

\footnotetext{
136 Other newspapers surveyed in making this assessment are the Dominion, the New Zealand Herald and the Evening Post.

${ }^{137}$ Evening Post, 8 Junc 1989. Similar views were expressed by the New Zealand Herald, 2 June 1989, p. 8.

138 Martin Plant, Eric Single and Tim Stockwell, cds., Alcohol: Minimising the Harm - What Works?, London, 1997, p. 4.

139 Plant et al, p. 5.

1+0. Inn Roche, 'The shifting sands of alcohol prevention: rethinking population control approaches', Australian and New Zealand Journal of Public Health, 1997, vol. 21, no. 6, pp. 621-625.

1+1 Plant, Single and Stockwell's Mimimising the Harm contains chapters on these and other interventions.
} 
continued to be influential in some countries, during the $1990 \mathrm{~s} \mathrm{New} \mathrm{Zealand} \mathrm{explicitly}$ abandoned its traditional public health approach, with its emphasis on availability restrictions, in favour of harm minimisation. The process began when the 1986 Working Party on Liquor rejected the availability theory, claiming that 'the evidence in support can be described as both dubious and elusive. ${ }^{142}$ A parliamentary select committee reporting on the Sale of Liquor Bill 1989 also dismissed the availability theory as a basis for legislation. ${ }^{143}$ Several MPs initiated a rear-guard action in support of availability restrictions when the Bill was debated in parliament. 'I subscribe heavily to the availability thesis - that is, the extension of outlets, however small, will result in further consumption and greater consumption will result in more problems,' National member Graeme Lee told the house. ${ }^{144}$ Another MP considered it was a simple matter of logic that an increase in the number of outlets could not occur without an increase in alcohol consumption. ${ }^{145}$ However most MPs ignored such concerns.

In 1991 the government-funded Alcohol Advisory Council (ALAC) began moving towards a harm minimisation approach following a 'sharply critical' review of its public health emphasis. ${ }^{146}$ The Ministry of Health underwent a similar shift, as shown by its 1996 National Policy on Tobacco and Alcohol. ${ }^{147}$ This trend was confirmed when the government's National Alcohol Strategy was released in 2001. ${ }^{148}$ The new approach was exemplified by ALAC's 'It's not the drinking; it's how we're drinking' campaign launched in $2005{ }^{149}$ Modern-day restrictionists found themselves fighting a losing battle, for they were operating in a climate in which 'the nineteenth-century ideals of frugality, hard work and self-control had been largely replaced by an emphasis on consumerism, leisure, and the unfettered pursuit of pleasure... ${ }^{150}$ However, as the twenty-first century controversy

\footnotetext{
142 Working Party on Liquor, p. 47.

143 Report of the Committee on the Sale of I iquor Bill, IJHR 1987-1990, volume xviii, I23 A, p. 25.

14 N/PI) 1989, volume 498, p. 10,946.

145 N/PL) 1989, volume 498, p. 10,981.

146 Marten I lutt and Philippa IIowden-Chapman, 'The Making of Alcohol Policy', in Peter Davis and Toni Ashton, eds., Health and Public Policy in New Zealand, Auckland, 2000, p. 263.

147 Ministry of Hcalth, National Drug Poliy Part 1: Tobacio and Alcobol, Wellington, 1996.

$1+8$ Ministry of I Iealth and ALAC, National Akobol Strategy 2000-2003, Wellington, 2001.

149 NI. IC media release, 'It's Not 'The Drinking; It's How We're Drinking', 7 Narch 2005 htrp:/ www alcoholorgn/ MediaReteascaspx?PostingID=3109, accessed 17 June 2005

150 I Jeather and Robertson, Problem Drinking, p. 29.
} 
over English pub opening hours has shown, the issue of the efficacy or otherwise of availability restrictions is far from a dead one.

Several historians have attempted to address the issue as to whether restricting liquor availability leads to less drinking. One controversy regarding the effectiveness of availability controls centred on mid-nineteenth century England. As was briefly outlined earlier, from the late 1820 s until the 1860 s those advocating the removal of restrictions on liquor sales were temporarily successful in some of their aims. This period was later to receive a bad press, particularly after the publication of a 1903 book by Sidney and Beatrice Webb that attacked the 1830 Beer Act and similar free trade measures. The Act led to a proliferation of 'beer shops' which the Webbs blamed for all manner of debauchery. ${ }^{151}$ In 1971 Brian Harrison, although no supporter of free trade, produced a lengthy rebuttal of the Webb's claims. He demonstrated that they had tended to rely on flawed data and biased anecdotal sources. ${ }^{152}$ The Beer Act had clearly increased the number of drink outlets, but it was less certain that this had resulted in increased drinking and related problems.

In relation to the imposition of prohibition in the United States, it has been commonly claimed that this reform led to reduced death rates from cirrhosis of the liver, thus providing indirect evidence that alcohol consumption had declined. ${ }^{153}$ In reality the example is somewhat problematic due to the lack of consensus as to the actual starting date for prohibition. The main reduction in cirrhosis mortality occurred before 1920 , leading some to argue that prohibition had no effect on alcohol consumption and abuse. ${ }^{154}$ But although constitutional prohibition came into effect in January 1920, liquor sales were actually banned from July 1919 as a belated 'wartime' measure. ${ }^{155}$ Even before that date many individual states went dry, particularly in the period 1914 to $1917 .^{156}$ These factors led some to claim that prohibition actually started as early as 1910 and was

\footnotetext{
151 Webb, History of Liquor Licensing in England, pp. 85-126. The Webbs devoted an entire chapter to the alleged sins of free trade in liquor, followed by a chapter entitled 'Tegislative Repentance'.

152 Harrison, Drinte and the Vittorians, pp. 81-6.

153 See Babor et al, Aleohol: No Ordinary Commodity, p. 125. The link between alcohol consumption and death rates from alcoholic cirrhosis of the liver is discussed in more detail in Chapter 6.

${ }^{154}$ Hanson, Preventing Akiohol Aluuse, p. 77.

155 Timberlakc, Prabibition and the Progressive Movement, p. 180.

156 Timberlake, pp. 166, 172-3.
} 
therefore directly responsible for the health improvements. ${ }^{157}$ A recent econometric analysis found that earlier state prohibitions appeared to have little effect on cirrhosis deaths, with rates falling at least as much in wet as in dry states, but that constitutional prohibition resulted in a reduction in cirrhosis death rates by up to 20 percent. The latest research therefore confirms that prohibition reduced liquor consumption to some extent. $^{158}$

The effectiveness of availability restrictions has not been closely examined by New Zealand historians. None of the writers discussed previously addressed the question of the success of the 1890 s reforms in limiting alcohol consumption and abuse, although Eldred-Grigg noted there seemed to be little obvious congruence between the successes of the temperance movement and changing patterns of alcohol consumption. ${ }^{159}$ Tony Simpson made a similar point rather more forcefully in a 1992 essay. ${ }^{160}$ Little has been written about the reforms introduced by the 1989 Sale of Liquor Act, which is surprising given their radical nature. Critical reviews of the major economic and social reforms of the late 1980 s and early 1990 s make no mention of the Act, including a 300-page book on the fourth Labour government that 'critically examines some of the government's key policy changes'. ${ }^{161}$ This thesis therefore makes extensive use of primary sources, in particular the 450-page report and 52 volumes of proceedings of the 1945 Royal Commission on Licensing.

The country most similar to New Zealand in its approach to liquor regulation has been Australia, although there was considerable variation between states. Milton Lewis' 1992 book subtitled Akohol and State Policy in Australia provided a reasonably comprehensive overview of legislative and policy changes in all six Australian states, concentrating mainly

\footnotetext{
${ }^{157}$ John Burnham, 'New Perspectives on the Prohibition 'Experiment" in Patbs into American Culture: Psychology, Medicine and Morals, Philadelphia, 1988, p. 175. Bumham justified the 1910 date by the fact that beer consumption peaked in that year, a somewhat circular argument.

I3甘 Angela Dills and Jeffrey Miron, 'Alcohol Prohibition and Cirrhosis' in American Law and Economics Review, volume 6, number 2, 2004, pp. 285-318.

159 Lildred-Grigg, Pleasures, p. 216.

160 Tony Simpson, 'The Demon Drink is Wide Awake!' in Shame and Disgraee: A History of Lost Scandals in Nen Zealand, Auckland, 1992, pp. 103-4.

161 Martin Holland and Jonathan Boston, eds., The Fourth Labour Government: Politics and Policy in New Zealand, sccond edition, Iuckland, 1992, back jacket. 'Tiwo books by Jane Kelsey - Rolling Back the State, Wellington, 1993 and The Nen Zealand Experiment, Auckland, 1995 also fail to mention the 1989 Act, as does Brian Easton, The Corporatisation of New Zealand, Auckland, 1997, and Indrew Sharp ed., Leap into the Dark: the Changing Role of the State in New Zealand Since 1984, Auckland, 1994
} 
on New South Wales and Victoria. ${ }^{162}$ Other works providing a pan-Australian historical overview are John Freeland's 1966 book on hotel architecture, Diane Kirkby's 1997 book on barmaids and Clare Wright's 2003 book on female publicans. ${ }^{163}$ Lewis outlined how availability restrictions were increasingly introduced in Australia in the late nineteenth and early twentieth century. Four Australian states introduced six o'clock closing in 1916. Two of these, Victoria and South Australia, continued with it for some 50 years, as did New Zealand. Victoria and South Australia were also similar to New Zealand in banning barmaids. ${ }^{164}$ In contrast New South Wales and Tasmania ended six o'clock closing well before New Zealand did - 12 and 30 years respectively - while Queensland and Western Australian never had it at all. New Zealand was therefore more at the 'restrictionist' end of the spectrum in relation to drinking hours.

New Zealand stands out even more with respect to controls on hotel numbers, as shown by Table 1. By 1910 New Zealand had substantially more people per licensed hotel than any Australian state. In the main the gap had closed by 1950, but compared with South Australia it had actually grown larger. Although the gap between New Zealand and New South Wales in hotel numbers shrank considerably, New South Wales had 337 licensed clubs in 1950 compared with just 46 in New Zealand. ${ }^{165}$ Controls on outlet numbers were introduced more quickly in New Zealand than in the Australian states. Even when the states introduced restrictions they were rarely as strict as in New Zealand and they were also generally loosened sooner. By 1983 Victoria, New South Wales, Queensland and Western Australia had all ended their bans on Sunday liquor sales, a change that would take a further 16 years to be adopted in New Zealand. Even South Australia, perhaps the most conservative of the states, lowered its drinking age to 18 in 1968, a move that would take a further 31 years in New Zealand. ${ }^{166}$

A significant difference between the two countries is that the issue of the effectiveness of availability restrictions was confronted earlier in Australia than in New Zealand. The terms of reference for a 1964 royal commission in Victoria specifically included an investigation of the potential social effects of extended drinking hours and increased

\footnotetext{
162 L.cwis, A Rum State.

163 J.M. Frecland, The Austratian Pub, Mclbournc, 1966; Dianc Kirkby, Barmaids: a History of Women's Work in Pubs, Cambridge, 1997; Clare Wright, Beyond the Ladies Lounge: Australia's Female Publicans, Melbourne, 2003.

to W right, Beyond the Ladies Lownge, p. 47 and Lewis, A Rum State, pp. 61, 78.

165 Frecland, The Australian Pub, p. 184 and Royal Commission on Licensing, p. 236.

166 Lewis, A Rum State, pp. 84-92.
} 
numbers of outlets. ${ }^{167}$ Another Victorian inquiry in 1976 also looked at this issue. ${ }^{168}$ This commission and another in New South Wales concluded that greater availability would not increase consumption and in Lewis' assessment the 'classical control policy' had been abandoned by the 1980s. ${ }^{169}$ As in New Zealand, alcohol researchers launched a counterattack and pushed unsuccessfully for a reversal of the liberalisation policy. ${ }^{17 n}$ Unfortunately Lewis does not provide any analysis of the merits of the arguments of the various parties on the desirability of availability restrictions. Like New Zealand, some Australian states underwent rapid changes in alcohol availability from time to time. The main change that has been subject to significant analysis was the shift in Victoria from six o'clock to 10 o'clock closing of bars in 1966 . One study analysed the impact of the change on alcohol consumption and another its effect on traffic accidents. They concluded that the change caused no increase in consumption or accidents. ${ }^{171}$

Table 1: Persons per Hotel Licence in New Zealand and Australian States, 1893, 1910 and 1950

\begin{tabular}{|l|c|c|c|}
\hline & 1893 & 1910 & 1950 \\
\hline New Zealand & 409 & 828 & 1700 \\
\hline New South Wales & 358 & 574 & 1598 \\
\hline Victoria & $\mathrm{N} / \mathrm{A}$ & 430 & 1343 \\
\hline Queensland & 329 & 367 & 967 \\
\hline South Australia & 480 & 621 & 1234 \\
\hline Western Australia & $\mathrm{N} / \mathrm{A}$ & 384 & 1307 \\
\hline Tasmania & 382 & 491 & 1157 \\
\hline
\end{tabular}

Sources: Figures calculated from Freeland, Australian Pub, p. 205, NZOYB 1998, p. 491, NZOYB 1990, p. 128.

Perhaps the most comprehensive national coverage of changes in liquor policy in a single country was provided by Craig Heron in his 2003 book Booze. ${ }^{172}$ Heron covered the

\footnotetext{
167 J.ewis, A Rum State, p. 82.

168 J.ewis, p. 88.

169 l.cwis, p. 95.

170 Lewis, pp. $182-190$.

171 Cited by John Nieuwenhuysen, 'Liquor control policy and alcohol availability-consumption relationships: reflections on the Victorian debate', in Australian Drug and Alcohol Review 1988; 7: 263-271, p. 264.

172 I Icron, Booze.
} 
complexities of the rise and fall of prohibition in various Canadian provinces and the later imposition of state control over aspects of the liquor industry. His book perhaps reveals as many differences as similarities between Canada and New Zealand in their respective approach to liquor issues. He portrayed prohibition as being unenforceable but he did not provide a detailed assessment of the effectiveness of lesser availability restrictions or state control. Rather frustratingly, Heron did not attempt to explain why Canadian provinces tended to opt for state control of liquor retailing in the post-prohibition period.

In this chapter it has been argued that an important reason for the retention of strict controls on alcohol in New Zealand during most of the twentieth century was a belief that these controls led to less drinking and a reduction in related problems. New Zealand was part of an international trend, at least in the English-speaking world, to increase restrictions on alcohol during the latter nineteenth and early twentieth centuries. From the 1890 s the country developed its own distinctive set of controls that fell well short of prohibition but were generally more restrictive than those imposed in comparable countries such as Australia. As will be discussed in subsequent chapters, these controls and their eventual removal led to occasional rapid changes in liquor availability. This thesis will use these rapid availability changes as experiments to test whether liquor restrictions did indeed work to limit drinking.

Chapter 2 introduces the main protagonists in New Zealand liquor debates, these being the liquor industry, the temperance and prohibition movement and governments. It discusses the extent to which these players were motivated by, or at least paid lip service to, the availability theory. New Zealand governments developed a marked reluctance to deal with liquor issues and commonly turned them over to independent inquiries, the most significant of which are briefly described in this chapter.

Chapter 3 focuses on another way that New Zealand governments avoided taking decisions on liquor issues by leaving such decisions to 'the people'. It argues that numerous national and local referendums on liquor issues, in particular the General Licensing Poll, helped keep liquor issues in the public eye for most of the twentieth century. Polls were numerous and frequent because of 1895 legislation that ensured that liquor polls would coincide with general elections, thereby helping inculcate in the political and popular imagination a link between liquor and referendums. Politicians were wary of abolishing the regular polls because they feared the wrath of the prohibition lobby - a 
lobby whose strength they were aware of because of the polls themselves. The chapter outlines how the General Licensing Poll came to be established and uses its results to track the fortunes of the prohibition movement during the twentieth century. It argues that the regular repetition of polls was an important reason for the longevity of liquor restrictions in New Zealand.

Chapters 4 and 5 outline the history of the main availability restrictions imposed on liquor in New Zealand. Chapter 4 covers the history of perhaps the most pervasive restriction, controls on the number of licensed outlets, which resulted in a virtual freeze on new liquor outlets for some 60 years. It discusses the report of the 1945 Royal Commission on Licensing, a commission set up primarily to deal with the outlet distribution problems caused by the freeze on licences, and speculates as to why the commission made its controversial recommendation to nationalise the breweries. It also outlines the history of another provision that helped maintain a lack of competition between bars - the requirement that most of those licensed to sell liquor should also provide accommodation for travellers - and discusses the longevity of no-licence or 'dry' districts in which liquor sales were in most cases illegal. Chapter 5 provides a history of the other main availability restriction - the institution known as 'six o'clock closing'. In particular it examines why early closing was soundly endorsed by a referendum in 1949 but was just as soundly rejected by a similar referendum 18 years later.

Chapter 6 uses New Zealand as a test case for the claim that restricting the availability of alcohol reduces its consumption. It first backgrounds the empirical evidence used to back claims of such a relationship. It then utilises the evidence published by government bodies to test whether the radical changes in tax rates, outlet numbers and hours of sale in New Zealand had the expected effects on alcohol consumption. Less radical changes in the form of changes in the drinking age are also discussed along with other relevant evidence on availability restrictions.

Chapter 7 first discusses some of the negative social effects that resulted from attempting to restrict the availability of liquor in New Zealand. It then considers why controls on outlet numbers and hours of sale did not appear to have led to the reductions in alcohol consumption that their supporters may have hoped. Finally it speculates as to why availability restrictions were retained for so long. It is proposed that the longevity of the restrictions resulted partly from the political caution brought about by regular liquor polls 
and the belief that they did indeed work to reduce drinking. It is also argued that New Zealand's isolation from overseas influences helped perpetuate an insular attitude that did not diminish significantly until the 1960s. Liquor restrictions came to be seen as an integral part of the national culture, a culture that was threatened by attempts at reform.

Chapter 8 summarises the main conclusions of this thesis and outlines the relevance they may have for contemporary debates over access to alcohol in Australia, Great Britain and New Zealand. 


\section{THE MAIN PROTAGONISTS}

This chapter introduces the main protagonists in the liquor debate - the prohibition and temperance movement, the liquor industry and government - and discusses the extent to which they supported or opposed availability restrictions. The attitude of the prohibitionists and the liquor industry were reasonably predictable. To the prohibition and temperance movement the idea that restricting the availability of alcohol would lead to less drinking and fewer social problems was a fundamental axiom. It is therefore not surprising that persistent and zealous campaigning by the movement was highly influential both in the imposition of restrictions and in their retention for many decades. The liquor industry tended to support many of the controls once they were in place, motivated primarily by economic self-interest rather than by ideology. The industry paid occasional lip service to the availability theory but generally remained silent as to its real motivation for supporting continued restrictions on alcohol sales.

However it is the increasingly diffident attitude of governments towards liquor issues that perhaps distinguishes New Zealand and helps explain the longevity of liquor restrictions. During the twentieth century alcohol became such a divisive and controversial topic that politicians were wary of taking any decisions on 'the liquor question'. This had not always been the case, for by the late nineteenth century many within parliament were in favour of restricting and banning alcohol. However the issue became a threat to party unity with the advent of party politics. As a result over time parliamentary representatives tried to defuse potentially divisive liquor issues through a variety of strategies including submitting them to 'the people' through referendums, passing them on to select committees and independent bodies such as royal commissions, and relying on non-party 'conscience' votes. This chapter briefly discusses some of the main inquiries into liquor control. 


\section{The Temperance and Prohibition Movement}

As was seen in Chapter 1 , the temperance and prohibition movement made a significant contribution to the triumph of restrictionism in a number of countries in the latenineteenth and early twentieth centuries. Ian Tyrrell has argued that the temperance movement was an integral part of what an English journalist described in 1902 as 'the Americanization of the world'. 'A large part of American expansion took the form not of political or even economic penetration but of the spread of institutions and cultural values. $^{2}$ These cultural values included those associated with the evangelical protestant revival of the early nineteenth century and opposition to anything, such as intemperate drinking, that might interfere with the religious experience of personal conversion that was central to it." Revivalists believed that '[o]nly the moral transformation of the population would achieve a perfect society and herald the millennium'. The United States had a central role to play in this process, for " $[t]$ he evangelicalist implied that in America God offered man a new start; America, they urged had a special mission to save the world from $\sin . . .{ }^{4}$ Saving the world from sin involved taking part in missionary activity, which was an integral part of the protestant revival and included spreading the temperance gospel. All but one of the 16 leaders of the American Temperance Society founded in 1826 was a member of American Board of Commissioners for Foreign Missions. ${ }^{5}$ Temperance was an American export industry in the 1820 s and 1830 s, reaching north into British North America and across the Atlantic to Scotland, England, Ireland, the North German States, and Scandinavia, and eventually further afield to Australia and New Zealand'. Much of the missionary work was directed at Britain, which quickly became a centre for temperance activity. The concept of the teetotal pledge originated there, and Britain and Irish campaigners eventually preached temperance throughout the world, including the United States. The temperance focus on Britain and Ireland was initially 'to

\footnotetext{
' Ian Tyrrell, Woman's World, Woman's Empire: Tbe Woman's Christian Temperanie Union in International Perspective, 1880-1930, North Carolina, 1991, pp. 4-5. William T. Stead titled a 1902 book The Americanization of the World. Note that in New Kealand the WCTU was called the Women's Christian Temperance Union.

${ }^{2}$ Tyrrell, Woman's World, Woman's Empire, p. 2.

${ }^{3}$ Timberlake, Probibition and the Progressive Movement, p. 5.

+ Bunkle, 'Origins of the Women's Movement', p. 55.

${ }^{5}$ Tyrrell, Sobering Up, p. 59.

${ }^{6}$ Heron, Booze, p. 53.

7 'Tyrrell, Woman's World, Woman's Empire, pp. 16-17.
} 
prevent their domestic campaign being hindered by drunken immigrants'. who helped inspire an Irish temperance movement was the Rev. Joseph Penny who paid a visit to his native country after ten years in America.' The Irish movement produced the abstinence crusade of Father Matthew, who subsequently toured Scotland, England and the United States in the cause of total abstinence. ${ }^{11}$ Later American temperance campaigners became more directly focused on Britain because of its economic strength and influence as the centre of a world-wide empire. ${ }^{11}$ Britain would provide a gateway to the rest of the world to help spread the temperance message. Between 1885 and 1891, nine temperance campaigners from Britain and the United States toured New Zealand. ${ }^{12}$ Many more were to follow. ${ }^{13}$

America led the way not just through proselytising activity but also by example. By the 1840s many temperance campaigners in the more urbanised eastern states had moved from moral suasion - attempting to convert individuals to a life of abstinence - to political compulsion. The result was the adoption of a prohibitory statute in Maine in 1851 that led to agitation throughout the English-speaking world for adoption of 'the Maine law'. ${ }^{14}$ Organisations such as the Sons of Temperance took the campaign throughout North America and by 1855 New Brunswick and 12 American states and territories had adopted similar prohibitory measures. ${ }^{15}$ In 1853 visiting American speakers inspired the establishment of the United Kingdom Alliance, which adopted a prohibitionist policy and agitated for a British version of the Maine law. ${ }^{16}$ That same year Maine Law Leagues were established in Auckland and Dunedin. ${ }^{17}$

Prohibitionism went into temporary decline in America in the decades after 1855 due to various political and enforcement difficulties associated with the Maine law, a decline in

\footnotetext{
8 Harrison, Drink and the I ictorians, p. 101.

${ }^{9}$ Malcolm, Ireland Sober, Ireland Free, pp. 61-3.

${ }^{10}$ Malcolm, p. 56.

11 Tyrrell, Woman's World, Woman's Empire, pp. 22-3.

12 McKimmey, 'I'he' l'emperance Movement in New Zealand', p. 80.

13 One of the most famous visitors was 'Pussyfoot' Johnson, a leading American prohibitionist who toured the country in 1922, V anguard, 2 November 1922, p. 10.

1+'Tyrrell, Solering Up, pp. 252-289.

${ }^{15}$ Heron, Boore, pp. 152-3.

16. Harrison, Drink and the Tictorians, pp. 196-7.

17 Mckimmey, 'The Temperance Movement in New Zealand', p. 55
} 
spirits drinking in favour of beer, and the intervention of more compelling issues during the civil war and its aftermath. ${ }^{18}$ However the seeds of prohibition had already been sown, not least by the establishment of evangelical temperance organisations. By the mid 1870 s the Order of Good Templars, described by Harrison as 'a pseudo-masonic organisation of the most extreme temperance zealots', had spread to England, Australia, South Africa and New Zealand. ${ }^{19}$ The Sons of Temperance, along with its sister organisation the Daughters of Temperance, also became established in New Zealand in the $1870 \mathrm{~s}^{20}$ But perhaps the most influential American temperance organisation to arrive in New Zealand was the Women's Christian Temperance Union (WCTU). The WCTU was established in Ohio in 1874 to revive the flagging American evangelical and temperance movement. Inspired by the efforts of its leader, Frances Willard, it became 'the largest and most effective women's organisation in the world'. ${ }^{21}$ One of the instigators of the organisation's spread was Mary Clement Leavitt, who spent some seven years travelling the globe as a WCTU envoy. ${ }^{22}$ In 1885 she visited New Zealand and established eight unions in her tour of the country. ${ }^{23}$ The WCTU was the first national body dedicated to prohibition and the first with explicitly political aims. Earlier New Zealand temperance bodies such as the Good Templars, the Sons and Daughters of Temperance and the Rechabites established local lodges that did much to popularise temperance thinking among their members but had no overt political ambitions. Their growth is probably largely attributable to the expansion of lodges and friendly societies in the days before government-sponsored social welfare. ${ }^{24}$

The most obvious political aim of the WCTU was female suffrage. 'Women's franchise would reform politics by restoring the moral purpose of government. It was the key strategy for achieving temperance and social purity, the essentials of a regenerate society. With the women's vote, the State would become an agency of God's purpose. ${ }^{25}$ This is

\footnotetext{
Is'lyrrell, Sobering Up, pp. 282, 290-316.

19 Harrison, Drink and the V'ictorians, p. 241, Tyrrell, Woman's World, Woman's Empire, pp. 4, 17-18, McKimmey, 'Temperance Movement in New Zealand', p. 58 .

${ }^{20}$ AlcKimmey, "The T'emperance Movement in New Zealand', p. 58.

${ }^{21}$ Bunkle, 'Origins of the Women's Movement', pp. 55-6.

22 Tyrrell, Woman's World, Woman's Empire, p. 1.

${ }^{23}$ Bunkle, 'Origins of the Women's Movement', pp. 57-8.

24 David Ihomson, A World Without Welfare: New Zealand's Colonial Experiment, Auckland, 1998, pp. 35-51. The Rechabites in particular were explicitly a mutual bencfit organisation for abstainers.

${ }^{25}$ Bunkle, 'Origins of the Women's Movement', pp. 57-8.
} 
not to say there had been no temperance political activity before the WCTU. In fact there had been plenty, from individual MPs putting forward bills proposing democratic mechanisms for limited local prohibition ('local veto') to petitions to close pubs on Sundays. ${ }^{26}$ However the movement did not gain an effective and lasting political voice until the mid-1880s. The foundation of the WCTU was followed in 1886 by an indigenous organisation, the New Zealand Alliance for the Abolition of the Liquor Traffic (generally called 'the Alliance'), established to provide a united front for the disparate prohibitionist activities. Unlike the WCTU, which was focused on a range of social purity issues, the Alliance was largely a single-issue organisation and became a formidable lobby group for temperance and prohibition. ${ }^{27}$ It lasted for over a century while the WCTU is still in existence. However the influence of both organisations faded rapidly after the 1920s.

Despite its international nature, it is notable that the success of the prohibition and temperance movement was largely confined to a small number of countries in North America, Scandinavia, Australasia, and to a lesser extent Britain. The movement's emphasis on drunkenness meant that it made little headway in those European countries where wine, often watered down and accompanying a meal, was the predominant alcoholic beverage. In 1885 a WCTU envoy resident in France grudgingly conceded that intoxication was 'less frequent here than in America'. Temperance societies in France, Germany and Switzerland preached moderation rather than abstinence. ${ }^{28}$ The identification of the movement with evangelical Protestantism, while a strength in many respects, also tended to limit its international influence. Tyrrell has noted that this factor helps explain the relative success of the movement in Sweden and Norway compared with Denmark, and its distinct lack of success in predominantly Catholic countries. ${ }^{29}$

The American domination of the temperance movement reduced considerably in the latter decades of the nineteenth century as 'Christian perfectionism' came into conflict

\footnotetext{
26 Mckimmey, 'The Temperance Movement in Ncw /ealand', pp. 65, 84-5.

27 Dalton considered that the WCTU's involvement in a variety of social purity issues diluted its temperance work, resulting in the loss of members to other prohibition organisations, Dalton, 'T'he Pure in Heart', pp. 3-4. The Alliance occasionally became distracted by other issues such as campaigning for religious instruction in schools, Cocker and Murray, p. 115.

28 Tyrrell, Woman's World, Woman's Empire, pp. 64-5.

29) Tyrrell, pp. 65-7.
} 
with the cultural and political realities of the Old World..$^{30}$ Some temperance bodies, including the British Women's Temperance Association, temporarily rejected the aim of prohibition altogether when faced with these realities. ${ }^{31}$ Scandinavian models influenced by socialism also challenged American predominance, particularly the system of limited municipal control established in Gothenberg, Sweden in 1865 and later imitated in Norway. The Scandinavian model even spread to the United States where a form of state-controlled liquor retailing was briefly instituted in South Carolina from $1893{ }^{32}$ In 1899 and 1903 British temperance campaigners Arthur Sherwell and Joseph Rowntree published influential books advocating state control of the liquor industry. ${ }^{33}$ State control options were already being proposed in Canada in the pre-war period. ${ }^{34}$

The Scandinavian model had little influence in New Zealand, at least within the prohibition movement, and the Gothenberg system was roundly criticised by the Alliance. ${ }^{35}$ The WCTU clung firmly to the American-inspired ideal of the perfectibility of society and had no interest in compromise positions. ${ }^{36}$ An early issue of the movement's newspaper the Prohibitionist ascribed the advances of the prohibition cause in the United States to the absence of the 'deeply rooted customs' that held back Europe. ${ }^{37}$ James Timberlake has argued that the American prohibition movement of the early twentieth century was an integral part of the Progressive Movement that aimed to improve democracy, make big business more accountable and improve the lot of the underprivileged. ${ }^{38}$ This progressive spirit was reflected in the New Zealand movement. 'Ours is the cause of progress and enlightenment and a free humanity; the great social forces of the future are on our side,' editorialised the Prohibitionist in $1900 .^{39}$ The newspaper's masthead proclaimed that 'New Times Demand New Measures'. ${ }^{40}$ In

\footnotetext{
30 'Tyrrell, W' oman's World, Waman's Empire, pp. 26-7.

31 ' lyrrell, pp. 265-6.

32 Tyrrell, p. $257-9$.

33 Joseph Rowntree and Arthur Sherwell, The Temperance Problem and Social Reform, London, 1899 and Public Control of the Liguor Traffi, London, 1903. See also 'Tyrrell, W'oman's World, W'oman's Empire, p. 269.

अ Hcron, Booze, p. 220.

35 George Dash, ed, No-License Handbook, Auckland, 1908, pp. 69-70.

36 Dalton, 'The Pure in I Ieart', p. 4.

37. The Probibitionist, 9 , lugust 1890, pp. 2-3.

38 Timberlake, p. 1.

39 The Probibitionist, 23 June 1900, p. 1.

40 The Probibitionsist, 14 June 1890 , p. 8.
} 
championing the virtues of the New World, prohibitionists were echoing members of the rising Liberal Party who advocated a new society that would leave behind the ills and vices of the Old World. ${ }^{41}$ The medical research that highlighted the detrimental effects of alcohol appeared to demonstrate that prohibition had science on its side. ${ }^{42}$ Prohibitionist publicised and embellished scientific findings, helping fuel anti-liquor feeling, ${ }^{43}$ The enfranchisement of women and prohibitionist successes in the 1890 s led some to believe that alcohol would inevitably be banned. A New Zealand Herald columnist in 1896 wrote that it is 'idle to close our eyes to the fact that Prohibition is coming. ${ }^{44}$ The New Zealand correspondent for the Sydney Bulletin confidently asserted in 1902: 'I hereby pronounce prohibition as inevitable as death in Maoriland'. ${ }^{45}$

Some have painted the prohibition movement in a more conservative light. McKimmey noted a tendency amongst prohibition advocates to see social problems, including poverty, as resulting from moral weakness. The emphasis on removing alcohol from the environment was therefore to remove temptation from the path of the morally susceptible. $^{46}$ Many prohibitionists believed this reform alone would be sufficient to cure social ills, rather than the social reforms advocated by political radicals. Phillips has argued that their desire to reform society was driven less by a radical impulse than by the Protestant ethic of restraint and moderation. ${ }^{47}$ Problems of social control created by the weakness of traditional institutions like the church, the community, and the class hierarchy could be met by self-control. Internalised discipline would guarantee both social order and economic productivity. ${ }^{, 4}$ According to Grigg, 'the prohibitionists were attempting to influence the structure and values of society by having it accept their predominantly middle class, puritan, Victorian morality of sobriety, thrift, industry to self-improvement and their concept of the suburban nuclear family. ${ }^{49}$ They believed that the moral regeneration of individuals and the strengthening of the family could solve the economic

\footnotetext{
${ }^{41}$ David Hamer, The New Zealand Liberals: The Years of Poner, 1891-1912, Auckland, 1988, pp. 54-59.

42 See Chapter 1.

t3 NeKimmey, "The Temperance Movement in New Kealand', pp. 165-8 and Eldred-Grigg, Pleasures, pp. 198-9.

${ }^{4}$ New Zealand Herald, 25 I pril 1896, p. 9.

t5 ( Quoted by Maclauchlan, The Story of Beer, p. 99.

th McKimmey, "The 'T'emperance Movement in New Zealand" pp. 101-2.

${ }^{77}$ Phillips, A Man's Country', p. 62 ,

48 Grigg, 'Citadels', p. 63

4) Grigg, p. 3.
} 
and social problems of the later colonial period. ${ }^{50}$ A serious weakness with Grigg's argument is that he tended to ignore the international character of the movement, instead seeing it as developing from peculiarly New Zealand circumstances. ${ }^{51}$ What is clear, however, is that prohibitionists were perceived by at least some of their contemporaries as reactionary killjoys. Cartoonists of the day not uncommonly portrayed them as lean and puritanical ascetics in stiff Victorian attire who aimed to ban a whole raft of life's pleasures. ${ }^{52}$ By the 1920 s this portrayal had become for cartoonists almost a prohibitionist archetype. ${ }^{53}$

An important reason for the success of prohibitionism in New Zealand is its close association with religion, in particular the pietist non-conformist churches. ${ }^{54}$ Numerically the most important of these were the Presbyterians and Methodists who made up over 30 percent of the population from the 1890 s to the 1950 s. $^{55}$ National censuses held on church attendance until 1926 showed that these churches had far higher attendance rates than the numerically greater Anglicans, giving them a potentially greater influence on their adherents. ${ }^{56}$ In the 1890 s the Presbyterian and Methodist hierarchies officially adopted a prohibitionist stance, and this hardened position greatly boosted the movement. ${ }^{57}$ Ministers of religion became increasingly prominent amongst its leaders. ${ }^{58}$ Members of the pietist churches were drawn by a belief "in the importance of personal conversion and of establishing a rigid moral framework within society to sustain morally correct behaviour. ${ }^{59}$ Intemperate drinking was seen as interfering with the possibility of religious conversion and clearly did not conform to the abstention from worldly pleasures advocated by many evangelists. ${ }^{6 i}$ Some demonised liquor. Alliance stalwart Leonard Isitt

\footnotetext{
50 Grigg, p. 30.

31 See especially Grigg, 'Citadels', pp. 1-4.

52 Sce, for example, Dalton, 'The Purc in Heart', pp. 40-1.

53 See, for example, Bollinger, 1967, p. 86 and Eldred-(irigg, Pleasures, p. 217.

5t The pietist non-conformist churches were those that had traditionally dissented from the Church of England and whose practices often included devotional circles for prayer and Bible study.

55 NZOYB 1954, p. 50.

36 II.R. Jackson, Churches and People in Awstralia and New Zealand, 1860-1930, Wellington, 1987, pp. 115-7.

it McKimmey, 'The T'emperance Movement in New 7.ealand' pp. 153-6.

58 Grigg, 'Citadels', p. 58.

59 Heron, Booze, p. 155.

61) Timberlake, Probibition and the Progressive Movement, p. 5.
} 
described alcohol as 'the foulest evil that ever cursed civilisation'. '.1 'We believe that alcohol is evil in itself and evil in its tendencies,' the New Zealand Methodist church submitted to the 1945 Royal Commission on Licensing. In contrast the Episcopal churches - the Anglicans and Catholics - were less supportive or at times even antagonistic towards prohibition. ${ }^{62}$ A major objection for these churches was that prohibition attempted to impose morality by coercion rather than through personal choice. As one Anglican Bishop argued in 1896, contact with the evil of drink was necessary in order to develop moral character and awareness through resistance to temptation. ${ }^{63}$

Reflecting its strongly religious basis, the anti-alcohol campaign was pursued with evangelical fervour, with songs and poems to inspire the faithful. 'Buoyed up by the deep conviction that their cause was of God, they bravely fought and sang through the fight,' wrote the Reverend Cocker in 1930, reflecting on the campaigns of the 1890s. 'Prohibition became the burning question of the day. Great was the enthusiasm. The blood of the reformers was hot. ${ }^{6 / 4}$ This fervour made the movement immensely influential. It was characterised by individuals who were energetic, educated and singleminded. Its strongly middle-class base meant it was well-funded. The message of the dangers posed by alcohol to health, morality and prosperity was communicated widely through public meetings, publications and the pulpit. ${ }^{6.5}$ Foreign prohibition activists regularly toured the country, Alliance activists published numerous pamphlets and other propaganda, and the movement had its own regular newspaper from the 1890 s to the 1950 s. ${ }^{66}$

Education of the young was also seen as an important tool in spreading the prohibitionist message. In the 1840s the English temperance movement began working with children. The Band of Hope organisation established in Leeds in 1847 spread rapidly during the $1850 \mathrm{~s}$ and $1860 \mathrm{~s} .{ }^{67}$ The organisation soon reached New Zealand, along with temperance

\footnotetext{
61 Cocker and Murray, pp. 66-7.

62 lildred-Grigg, Pleasures, pp. 185-6.

6. Cited by Inthony Grigg, 'Prohibition: the Church and Labour - a programme for social reform, 1890 - 1914' in NZJH, vol. 15, no. 2, October 1981, p. 143.

${ }_{6}^{6+}$ 'The Reverend J. Cocker in Cocker and Murray, p. 9.

65 Eildred-Grigg, Pleasures, pp. 181-2.

66 McKimmey, 'The Temperance Movement in New 'Zcaland 1835-1894', pp. 71-2, Eldred-Grigg, Pleasures, pp. 181-2.

${ }^{67}$ I Jarrison, Drink and the Victorian, pp. 192-4.
} 
kindergartens, Bible classes, and the Loyal Temperance Union. ${ }^{6}$ The WCTU undertook pioneering work in pre-school education. ${ }^{69} \quad$ The Bands of Hope were particularly effective in obtaining at least temporary youthful converts to the temperance cause, both through rousing songs and pledges of abstinence. ${ }^{70}$ On occasion children were encouraged to take part in prohibition demonstrations. ${ }^{71}$ Prohibitionists also agitated for temperance education in schools. ${ }^{72}$

Another vital tool of the prohibition movement was democracy. Prohibitionists encouraged their supporters to vote on single-issue lines - to support only those candidates who undertook to suppress the liquor traffic. ${ }^{73}$ In this they were hugely successful. Grigg found that 40 percent of MHRs elected to general seats in 1914 had expressed some support for prohibition. ${ }^{74}$ Long-serving MHRs such as Tommy Taylor, Leonard Isitt and James McCombs gave lifetime service to the cause. Earlier prohibition supporters included former Premiers William Fox and Robert Stout. ${ }^{75}$ As will be seen in the next chapter, the movement was even more successful in its use of local and direct democracy to try to suppress the liquor traffic.

The active involvement of many women in the prohibition movement was an important source of its strength. Although historians have pointed out that the leadership of the main prohibition organisations was overwhelmingly male, women were unusually influential by the standards of the time. ${ }^{76}$ The banning of alcohol had, in the eyes of both male and female temperance activists, huge advantages for the family. Dissolute men would no longer be able to abandon their wives and families for the attractions of the public bar. Women and children were seen as the ultimate victims of a man's drinking habits. They suffered from physical abuse when the husband or father returned drunk;

\footnotetext{
is Bunkle, 'Origins of the Women's Movement', p. 60.

${ }^{69}$ Grimshaw, Women's Suffrage in New Zealand, p. 32-3.

${ }^{70}$ Kenncth Manson, When the Wine is Red: the New Zealand Temperance Alliance Centennial Review, 1886-1986, Wcllington, 1986, pp. 46, 74-78

${ }^{71}$ Dalton, 'The Pure in Heart', p. 27 and Grigg, 'Citadels', p. 262.

${ }^{72}$ McKimmey, 'The Temperance Movement in New 'Kealand 1835-1894', pp. 70-1.

${ }^{73}$ Grigg, 'Citadels', p. 230.

$7+$ Grigg, pp. 393-4.

75 Cocker and Murray, pp. 223-256.

76. Dalton, 'The Pure in Heart', pp. 16-44 and Inthony Grigg, 'Prohibition and Women: 'T the Preservation of an Ideal and a Myth', NZJH, vol. 17, no. 2, October 1983, p. 152.
} 
they had to endure starvation and penury when his earnings went on liquor." ${ }^{77}$ Many prohibitionists supported the WCTU's suffrage campaign because they believed that women would use their votes to help abolish the liquor traffic. ${ }^{78}$ With benefit of hindsight it can be seen that they placed excessive faith in the uniformity of female voting behaviour. When Linda Moore undertook a sophisticated statistical analysis of voting patterns in early prohibition polls she found that, while women appeared generally more likely than men to support prohibition, the difference in voting patterns did not seem to be large. ${ }^{79}$ Many women clearly did not want prohibition, although they voted for it in sufficient numbers to help keep up the hopes of temperance activists for several decades.

As was noted in the previous chapter, prohibitionists found themselves on increasingly strong ground in the fields of health and economics. Their case was less convincing when it came to issues of enforcement. Opponents of prohibition argued that it was impossible to adequately enforce a law against an activity that was both popular and widely perceived to be morally acceptable. Thus William Salmond wrote in 1911 that the millions 'voluntarily spent on wine proves the existence of a demand that no legislative edict can stop. ${ }^{80}$ Once prohibition or no-licence was introduced in various places throughout the world there were ongoing arguments about the extent to which the law was being enforced or flouted. The arguments became particularly heated when opponents of American prohibition claimed 'a Tidal Wave of Wetness' as the smuggling and illegal manufacture of liquor became rife. ${ }^{81}$ The standard prohibitionist response was to advocate increasingly repressive measures by the authorities. ${ }^{82}$ The Alliance claimed that American prohibition was almost self-financing once the income from fines was taken into account. ${ }^{83}$ This argument put the Alliance in a difficult position as it was tantamount to admitting that the prohibition laws were being widely flouted.

\footnotetext{
77 Phillips, A Man's County, pp. 59-60.

78 Dalton, "The Pure in Heart', pp. 14-29.

79 Jinda Moore, 'Gender Counts: Men, Women and Flectoral Politics 1893-1919', MA thesis, University of Canterbury, 2004, pp. 220-238. Moore utilized the fact that some electorates had a higher proportion of female voters than others, using a sophisticated statistical technique to control for the 'ccological fallacy'.

81) William Salmond, Probibition: A Blunder, Duncdin, 1911, p. 49. Salmond rather oddly used the word 'wine' to refer to all alcoholic drinks.

81 Cheerio, 2 October 1922, p. 8.

82 Scc, for cxample, PRCL pp. 3565-6.

83 J. Malton Murray, The Nen Zealand Alliance Handbook: a Handy Guide for Speaters and Writers, Wellington, 1925, p. 163.
} 
Prohibitionists often invoked the availability theory when arguing that restrictions should be strengthened or retained. A prohibition advocate wrote in 1893 that the temptation of the public house needed to be removed, for much drinking 'would not be thought of but for the publican's open door. ${ }^{84}$ The man helpless in the fact of temptation was a recurring figure in Alliance propaganda. ${ }^{85}$ In 1903 prohibitionists celebrated when publicans agreed to abolish free counter lunches, for these were regarded as a 'devilish means to entice people into public houses to drink. ${ }^{86}$ The legal counsel for the Alliance told the 1945 Royal Commission on Licensing that "[a]ny new facilities inevitably have the effect of increasing the total demand for alcoholic liquor. ${ }^{87}$ The WCTU agreed. ' [] $\mathrm{t}$ is the opportunity for drinking.... which leads to excess. ${ }^{88}$ The idea that temptation might stimulate demand made temperance groups wary of supporting any improvements to drinking conditions, for better conditions made bars - and by implication drinking - more attractive. As one correspondent to the Probibitionist noted in 1899, "Tthe more respectable the trade is made, the harder it will be to get rid of it ${ }^{89}$ The dilemma as to whether to support improvements to drinking conditions regularly confronted the prohibition movement. Thus the Presbyterian Church submitted to the 1945 Royal Commission that it approved 'as an experiment' the provision of seats, tables and food in bars. The submission explained the church's reluctance to advocate these minor reforms. We realise that this probably means that people who formerly were disgusted by conditions obtaining in bars, may become more habituated to association with drink. ${ }^{90}$ Such consequences were unacceptable to hardline prohibitionist groups such as the WCTU, who staunchly opposed tables and chairs in bars. ${ }^{91}$ A decade later an Alliance committee reported that ' $\mathrm{r}]$ espectable drinking conditions will create a drinking fashion that can have

\footnotetext{
84 I.R. Mtkinson in the Probibitionist, 27 July 1893, p. 7.

85 Sec, for example, Hillary Knowles, 'Promoting Prohibition: The Ncw ' Zcaland Alliance for the Abolition of the liquor Traffic's Campaign 1914 to 1920', B A I Ionours research essay, Massey University, 2002, p. 29.

86 Grigg, 'Citadels', p. 208.

${ }_{77}$ PRCL, p. 7215. The Alliance was still making this claim over 40 years later, Report of the Committec on the Sale of Liquor Bill, p. 22

88 PRCI., P. 6057.

89 The Prabibitionist, 29 A Ipril 1899, p. 5.

${ }^{9}$ PRCL, p. 3138.

"11 PRCL, p. 1627.
} 
a detrimental effect on the nation's health." The temptation theory remained alive and well amongst the shrinking band of prohibition supporters.

\section{The Liquor Trade}

The liquor industry traditionally consisted of diverse groups, often with conflicting interests. The various protagonists included publicans, brewers, wine producers, wine and spirits merchants, licensing trusts, chartered clubs, restaurateurs and trade unions. The unity, influence and balance of power between these groups varied over time. Until the late nineteenth century publicans dominated the liquor trade. The breweries that provided them with draught beer were no more than one among several suppliers of alcohol. In fact spirits were more popular than beer until the 1880 s, for their high alcohol content meant that spirits kept and travelled well, while beer was bulky and kept poorly. Nineteenth century brewing operations were almost exclusively local concerns; ' $t$ ] he size of the plants and the prevailing transport infrastructure and associated costs made it difficult to break out into markets beyond the towns and cities in which the breweries were based'. ${ }^{93}$

But the balance of power within the industry gradually shifted, giving it a more united voice. The price of beer reduced as the breweries became more efficient and the transport infrastructure improved. Brewers benefited from a government ban on the local distillation of spirits in $1874 .^{94}$ Tariffs advantaged local breweries over imported liquor. As the popularity of beer increased, hotels came to rely more heavily on the breweries for their supplies. This reliance worked both ways, for breweries needed reliable outlets for their draught beer, preferably nearby because of transport costs. When the government put a virtual freeze on new pubs in the late nineteenth century, brewers began purchasing hotels to secure beer outlets, which became an increasingly scarce resource. Brewery hotels were then either managed directly by brewery employees or leased to publicans who agreed to sell the owner's beer - an arrangement known as the 'tie.". An alternative way of acquiring new outlets was to simply buy up rival breweries. This resulted in some large and prosperous enterprises that eventually dominated the industry - in particular

\footnotetext{
92 Sccond Report of the Alliance Special Committec, 16 July 1956, in New Zealand Alliance: Records, 77-206-06/06, Nexander lurnbull I ibrary.

${ }^{03}$ Mclauchlan, The Story of Beer, p. 52.

${ }^{94}$ Bollinger, 1967 , p. 30 .

${ }^{95}$ Report RCL, Pp. 40-45.
} 
New Zealand Breweries founded in 1923 and Dominion Breweries founded in 1930. This agglomeration trend accelerated after the Second World War. In 1945 there were still 30 brewing companies. By 1960 just 11 remained, and by 1970 there were only four. ${ }^{96}$ This trend was motivated by factors other than the acquisition of hotel outlets. Improved transport meant fewer breweries were needed. The 'continuous fermentation' brewing method increased efficiency, and import and price controls limited competition. ${ }^{97}$

Because the industry initially consisted of thousands of publicans and dozens of small breweries and wine and spirits merchants, it was poorly placed to present a united front against the prohibitionist threat. Publicans formed licensed victuallers' associations, but these tended to be regionally based and lacked a national voice. ${ }^{98}$ The difficulty of forming a national lobby group from the various factions was illustrated in the 1890 s and early 1900s. The Licensed Victuallers' Association of New Zealand was formed in 1890 to represent brewers, wine and spirits merchants, hotel keepers, hotel owners and 'aerated water manufacturers.'." In 1893 it changed its name to the Brewers' and Wine and Spirit Merchants' Association of NZ and was thereafter generally known as the Brewers' Association. ${ }^{150}$ The name change appeared to reflect the fact that the association was primarily representing the interests of the owners of breweries and wholesale outlets rather than publicans. By 1915 the Brewers' Association appeared concerned almost solely with fighting beer duty increases. ${ }^{101}$ Meanwhile publicans took on the Licensed Victuallers name to represent their interests at a national level, a name they retained until 1959 when the organisation became the Hotel Association of New Zealand. ${ }^{112}$ In 1910 a Trade Defence Fund levy was established to fight prohibition. ${ }^{103}$ Another attempt at forming a national body to represent the industry was made during the First World War

\footnotetext{
$96 \mathrm{Mcl}$ auchlan, Story of Beer, p. 73.

${ }^{97} \mathrm{Mcl}$ auchlan, Story of Beer; pp. 17-18, 73, 105.

98 Eildred-Grigg, Pleasures, pp. 208-9.

"9) Minutes of the New Zealand Licensed Victuallers' Association of New Zealand, 1 October 1890, in Brewers' and Wine and Spirit Merchants' Association of New Kealand: Records, MS-Papers-1621-01, Alexander Turnbull Library. The Association went through a number of name changes due to a shifting membership.

100 Ninutes of the New Zealand I.icensed Victuallers' Association of New Zealand's annual meeting, 10-11 July 1893 in Brewers' and Wine and Spirit Merchants' Association of New Zealand: Records, MS-Papers-1621-01, Alexander Turnbull l ibrary.

101 Minutes of the Brewers' Association 1915-1918, in Brewers' and Wine and Spirit Merchants' Association of New Zealand: Records, MS-Papers-1621-02, Alexander 'lumbull J ibrary.

102 Brien, 100 Years of Hospitality, pp. 12-15, 70.

103 Brien, p. 16.
} 
when the National Council of the Licensed Trade of New Zealand was established. ${ }^{104}$ The National Council, as it was generally known, continued to represent the industry until it changed its name to the Liquor Industry Council in 1971. ${ }^{105}$ The National Council's chief purpose was to organise for the continuance vote in the triennial poll and represent the industry in major inquiries such as the 1945 royal commission. ${ }^{106}$

Bollinger argued that industry groups such as the National Council tended to advocate for the retention of existing restrictions rather than their removal. His contention that the New Zealand liquor industry was motivated by economic self-interest to support restrictions on alcohol availability was supported by economic historian Tim Mulcare in a 1999 paper. $^{107}$ The support of liquor trade organisations for ongoing availability restrictions is best understood by the fact that they were representing those already in the industry. Existing players tend to resist the idea of competition and to lobby for measures to keep out possible new entrants and to retain any restrictive measures already in place. Lobbying for tariffs on foreign competitors is a common example of such behaviour. Most policy positions taken by the liquor trade over many decades can be understood by applying the principle that it was supporting those already in the industry from competition from those outside of it. As the Secretary for Justice noted in his briefing to the 1974 Royal Commission on the Sale of Liquor, 'there will be a contest between those for whom the status quo is sufficiently profitable and who feel they have only to lose from any extensive change and those who seek a share of the spoils'. ${ }^{108}$

The tendency of temperance legislation to divide the industry into insider and outsider camps was noted as early as 1881 when MHRs debated the 1881 Licensing Bill whereby no new licences could be issued without a local poll. 'It gives the people the splendid chance of joining hand and heart with the publicans in forming a grand monopoly,' a Dunedin MHR told the house. 'They are to join with certain gentlemen who have got the

\footnotetext{
10+ The exact date it was formed is unclear but the National Council represented the industry in a delegation to the Prime Minister in July 1917, Auckland Star, 21 July 1917, p. 6.

Ius Stace, p. 429. The New Zealand Liquor Industry Council changed its name again in 1990 to the Beer, Wine and Spirits Council, which now primarily represents the two major brewing companies, Beer, Winc and Spirits Council, 'Policy Statements', hitp: / www beerwsc.co.nz/page aspipagelD=21, accessed 10 November 2005. 
trade in their hands now, to prevent new persons entering into that trade. ${ }^{109}$ The government Minister who introduced the Bill acknowledged that it advantaged vested interests, although the freeze on new licences was supposedly in the interests of temperance. $^{110}$ Once it had won the battle against prohibition in the 1930 s, the National Council and its successors focused their efforts on protecting those within the trade from competition. In 1945 the National Council submitted to the Royal Commission on Licensing that there was no need for new liquor licences, a position enthusiastically supported by the Alliance. ${ }^{111}$ The Council opposed the licensing of restaurants, cabarets and nightclubs, and the issuing of more club charters. ${ }^{112}$ Fifteen years later a government select committee reported that the principal opposition to the licensing of restaurants came from 'the licensed trade' and from temperance groups including the Alliance. ${ }^{113}$ The Liquor Industry Council, successor to the National Council, invoked the availability theory in support of continued restrictions on new outlets in its submission to a 1974 Royal Commission. "The control of outlets and availability of liquor to the general public has always been considered in most countries operating a fairly sophisticated licensing system to be of prime importance. Most authorities accept that problems with alcohol are compounded by an excessive number of outlets.'114 The Council's submission opposed the sale of wine in supermarkets. ${ }^{115}$ Licensed restaurateurs also invoked the availability theory in response to proposals that customers might be permitted to bring their own alcohol to unlicensed restaurants, claiming that BYO restaurants 'encourage excessive consumption, ${ }^{116}$

In 1989 industry opposition to new outlets was still apparent. A select committee reported that 'certain sectors of the liquor industry also argued, as they have in the past, that a proliferation of licences will lead to increased alcohol abuse'. ${ }^{117}$ The committee noted that the main submissions against allowing more outlets by abolishing the needs test

\footnotetext{
109 NZPD 1880, volume 35, p. 114.

110 N7PD 1880 , volume 35, p. 108 .

111 PRCl, pp. 7589 and 7213 .

112 PRCL, p. 7589, Report of the 1945 Royal Commission, pp. 237-8, and Bollinger, 1967, pp. 89, 98.

$1{ }^{3}$ Report of the Select Committee into Liquor Licensing, AJI IR 1960, I.17, p. 51.

114 New Zealand I iquor Industry Council, Sulmission to the Royal Commission on Liquor, February 1974, Section 1, p. 24.

115 New Kealand Liquor Industry Council, Section 3, pp. 34-39.

116 Submissions to the Royal Commission on the Sale of Liquor, submission 121, p. 10.

117 Report of the Select Committee on the Sale of Liquor Bill 1989, AJI IR 1987-1990, volume XVIII, I23 A, p. 24.
} 
came from the industry, from the alcohol research community and from temperance groups including, inevitably, the Alliance. ${ }^{118}$ Industry groups claimed the sale of liquor in supermarkets and other food outlets would lead to increased consumption. ${ }^{119}$ The Service Workers' Federation likewise argued that wine in supermarkets would expose women to temptation. ${ }^{12}$ The Hotel Association was more honest about its motivations, although still with the pretence of being public-spirited, in claiming it cannot be in the community's interest if licensed establishments fail'. ${ }^{21}$ Despite the similarity in trade and temperance views on new outlets, the industry did not appreciate public attention being drawn to the fact. In 1965 the Hotel Association complained to the Prime Minister after the Minister of Justice claimed in a television interview that the Association was seeking similar ends to the Alliance by opposing new outlets. ${ }^{122}$

The industry and prohibitionists were also surprisingly united on the issue of dry districts - those areas of the country where no hotel or bottle shops were permitted. The residents of most areas that went dry between 1894 and 1908 had the opportunity to vote every three years to allow a return of alcohol sales, with a three-fifths majority required for 'restoration of licences', as it was known. A number of submissions to the 1945 Royal Commission on Licensing called on these dry districts to be abolished or for restoration to be effected by a bare majority. ${ }^{123}$ However the National Council was not among those calling for such changes. ${ }^{124}$ Bollinger explained the industry's attitude:

\footnotetext{
Many of the No Licence victories, especially those in the suburban areas on the fringes of cities (where most of them took place) were no embarrassment whatever to the trade. The breweries, which were gaining an increasing control over the hotels in the cities, found the expulsion of their more far-flung outposts from the suburbs helped them in two directions: it enhanced the value of the trade done at their city pubs, with a greatly reduced outlay; and it took the sordid sights of closing-time away from the residential areas....Although the trade organisations are still today fighting hard at each election to
}

\footnotetext{
tis Report of the Select Committec on the Sale of Liquor Bill 1989, p. 22.

119 Select Committee, pp. 56-7.

120 Select Committee, p. 24.

121 Select Committee, p. 22.

122 Stace, p. 424.

123 PRCL, Pp. 109, 335, 5239 and 7768-9.

12+ PRCL, pp. 7557.
} 
win back Oamaru...they conduct no campaign whatever for restoration of licences in the dry suburban areas in the big cities. ${ }^{125}$

An example backing up Bollinger's claims can be seen in the 1935 licensing campaign, when the National Council advertised in the Dominion newspaper urging the residents of the town of Masterton to vote restoration but placed no advertisements calling for the restoration of licenses to the dry Wellington suburbs. ${ }^{126}$ In subsequent decades all the provincial dry districts voted to allow liquor sales leaving significant parts of suburban Auckland and Wellington as the sole remaining dry districts. In 1974 the Liquor Industry Council called for the retention of the 60 percent threshold required for these areas to restore licences, as it 'preserves a proper balance of the status quo against the forces of change'. ${ }^{127}$ The Council made it clear it did not include itself among the forces of change'. The industry's stance in support of dry districts provides an excellent illustration of its bias in protecting those within the industry from competition. If the dry suburbs of Auckland and Wellington went wet, any new outlets established would take business from existing liquor providers nearby or in the central city.

However, despite Bollinger's claims that the liquor industry supported six o'clock closing, in reality the industry was divided on the issue of hours of sale. As will be seen in Chapter 5 , the support of many publicans for early closing may have prevented the National Council coming out firmly in support of more liberal hours. ${ }^{128}$ The Council proposed a limited extension of drinking hours in 1945 but did not campaign publicly to end six o'clock closing in the referendum of 1949. In 1955 the Council unexpectedly came out with a statement favouring extended hours, although its enthusiasm for this reform was inconsistent over the following decade. ${ }^{129}$ In 1967 the Hotel Association campaigned for people to vote but did not suggest which way, probably due to divisions within its membership. Hotel unions opposed later closing. After 1967 the industry tended to

\footnotetext{
125 Bollinger, 1959 , p. 59.

$126^{\circ}$ The Dominion, 23 November 1935, p. 28 and all issues 16-26 November 1935.

127 New 7ealand I iquor Industry Council, Section 2, p. 36.

128 However not all publicans supported six o'clock closing. In 1933 some Taranaki publicans called for extended hours in the vain hope that this might reverse the major downturn in liquor sales brought on by the depression, Vanguard, Junc 1933 , p. 4

12) Dominion, 23 May 1955, p. 10.
} 
support more flexible drinking hours, although unions continued to oppose any increase in total opening hours to avoid 'casualising' the industry. ${ }^{130}$

On another issue the liquor industry regularly lobbied more vociferously than temperance groups for continued restrictions. This was the alcohol-accommodation link - the requirement that anyone with a publicans licence should also have to provide accommodation for travellers. The link is discussed in detail in Chapter 4, where it is argued that the industry supported it because it raised the costs of entry into the industry and facilitated after-hours trading. Prohibitionists on the other hand tended to oppose the link because it implied that it was unprofitable to provide accommodation for travellers unless that accommodation was subsidised by liquor sales.

At times official inquiries appeared to be aware of the industry's self-interest in supporting restrictions. The 1945 royal commission speculated that National Council opposition to licensed restaurants was motivated by fear of competition. ${ }^{131}$ The 1986 Working Party on Liquor noted an apparent contradiction in the Hotel Association submission that advocated a lower drinking age and more flexible hours but also called for a continued freeze on new licences, supposedly in the interests of temperance. The working party surmised that the association 'wants greater flexibility for its members but also wants restrictions on the possibility of increased competition. ${ }^{132}$

The strange partnership that the liquor industry enjoyed with the temperance movement faded during the century as the fortunes of the prohibitionists went into decline. Instead, from the 1970 s the alcohol research community largely replaced the temperance movement in opposing new outlets in both Australia and New Zealand. In 1988 John Nieuwenhuysen, who had conducted a review of the Victorian government's alcohol policies, expressed frustration that health advocacy groups sided with industry bodies in opposing his liberalisation recommendations. ${ }^{133}$ Around the same time New Zealand's alcohol research community was criticising proposals to further relax restrictions on

\footnotetext{
${ }_{130}$ Sce, for example, Report of the Sclect Committec on the Sale of Liquor Bill 1989, p. 62,

131 Report RCL, op cit, p. 195

132 Working Party on Liquor, p. 33.

133 John Nieuwenhuysen, Tiquor control policy and alcohol availability-consumption relationships: reflections on the Victorian debate', in Australian Drug and Alcobol Revien 1988; 7: 263-271.
} 
liquor. ${ }^{134}$ 'There should be no general increase in the availability of alcohol,' argued ALAC in $1986 .{ }^{135}$ ALAC was joined in this sentiment by the Hotel Association, which campaigned against allowing more competition between liquor outlets with the beer mat slogan 'If you don't want the sale of liquor to be a free-for-all, say so.' ${ }^{, 36}$ Yet alcohol researchers seemed oddly unaware that they were commonly arguing on the same side as the industry. For example a 1986 publication by Auckland University's Alcohol Research Unit claimed: 'Vested interests involved in the production and distribution of alcohol will, in general, attempt to ensure that changes in the control structure occur only in the direction of increasing rather than reducing availability thereby maintaining sales and profit levels. ${ }^{137}$ As has been seen, vested interests in the trade often saw their profitability as best served by the retention of existing availability restrictions.

The industry did not agree with the Alliance and alcohol researchers on every issue. In particular, it opposed the triennial licensing poll. For many years the poll generated a high degree of uncertainty for publicans and brewers. It could end their right to operate, without compensation. In the 1920 s when prohibition was near to being carried, little was invested in new plant or in improved drinking facilities. ${ }^{138}$ This situation continued for many years because of the depression and the Second World War. The National Council continued to lobby against the triennial poll in the post-war period with little success. The fact that the poll stayed in place despite industry opposition for over seven decades perhaps indicates that industry lobbying was generally effective only so long as the trade was singing a similar tune to that of the prohibitionists.

The industry also opposed restrictions its members believed would result in decreased alcohol consumption. From 1968, when the minimum legal drinking age was 21, the industry consistently advocated it be lowered to 18 , the age before $1910 .^{139}$ This position was no doubt largely motivated by the fact that a lower drinking age would enlarge the potential market for alcohol. The liquor industry also understandably resisted increases in

\footnotetext{
134 AL.AC, Lining With Alcohol: a Sulmission to the Working Party on the Liquar Laws, Wcllington, 1986, pp. 11-14, 21-22, II.AC, 'The Ivailability Issue', Sale of Liquor Act 1988: ALAC Update Number 2, Wellington, 1988 and Report of the Committee on the Sale of Liquor Bill, pp. 22-25.

135 AL.AC, Living With Aliohol, p. 2.

${ }^{136}$ Brien, 100 Years of Hospitality, p. 123.

137 Casswcll and Stcwart, Availability of Alcohol in New Zealand, p. 15.

${ }^{138}$ Mulcare, 'The Control of Alcoholic Beverage Markets', p. 154 and Mclauchlan, The Story of Beer, pp. 69-70.

139 Stace, pp. 350-369. The drinking age was lowered to 20 in 1969.
} 
alcohol taxes, which were found to reduce demand for spirits in particular. ${ }^{140}$ Their opposition was often unnecessary, however, for the political unpopularity of such increases acted as a disincentive for governments to implement them. ${ }^{141}$ Many prohibitionists also opposed increases in alcohol taxes on the grounds that they would make the government further dependent on liquor revenue, for their opponents commonly argued that prohibition would lead to a significant revenue loss. ${ }^{142}$

In general the New Zealand liquor industry responded in fairly predictable ways to restrictions on liquor availability, broadly in line with the self-interest of those already in the industry. In some cases the industry supported continued controls, in others it was united in opposing them, and in still others different industry sectors had different views. These variations in approach cast doubt on Bollinger's contention that the support of the industry for availability and other restrictions was a major reason for their retention. Furthermore, in other countries the liquor industry often supported restrictions for reasons similar to those applying in New Zealand. In the $1880 \mathrm{~s}$, New South Wales publicans and temperance supporters were united in using the local option laws to try to prevent new outlets from opening. ${ }^{143}$ Over a century later the Australian Hotels' Association condemned the 'proliferation of outlets' that would result if proposals to allow greater outlet competition were implemented in New South Wales. To combat similar proposals in Tasmania, liquor interests commissioned a research report to demonstrate the allegedly detrimental social effects of increased competition. ${ }^{144}$ Because of the apparent similarity in attitude towards liquor restrictions on the part of the Australian and New Zealand liquor lobbies, the attitude of the New Zealand liquor lobby probably does little to explain why controls were generally stricter here than in Australia.

\footnotetext{
140. L.shton and Casswell, Alcohol Pricing Policy in New Zealand, p. 15.

1+1 Eldred-Grigg, Pleasures, p. 201.

$1+2$ Eldred-Grigg, pp. 72, 201-2.

143 Lewis, A Rum State, p. 56.

IH Geesche Jacobsen, Tet more outlets sell liquor, Carr told', Sydney Morning Herald, 16 February 2004, accessed at www.smh.com.au/articles/2004/02/15/1076779837828.html on 19 February 2004. Under the Federal government's national competition policy, lustralian states were being forced to remove barriers to competition in a number of industries including liquor.
} 


\section{Governments}

New Zealand governments traditionally relied heavily on the revenue from alcohol to finance their spending. ${ }^{145}$ In the late nineteenth and early twentieth centuries alcohol taxes made up eight to ten percent of government revenue, with licence fees making an additional contribution. ${ }^{146}$ As a result there was often opposition in parliament to measures seen as likely to reduce alcohol consumption to any significant degree because of the possible effect on the tax take. ${ }^{147}$ This argument was regularly disputed by prohibitionists, who claimed the lost revenue would be more than made up from the tax savings generated by banning alcohol. As a result some parliamentarians supported the prohibitionist line that any loss of tax revenue would be compensated for by a decline in public expenditure on gaols and hospitals and by increased private spending on other goods and services. ${ }^{148}$ However other members supported trade arguments about the effect of prohibition on the economy, with potential job losses claimed in hotels, breweries, barley and hop farming and a host of other areas. ${ }^{149}$ Some in parliament were closely associated with the liquor industry. ${ }^{15 i}$ These different viewpoints became particularly apparent in the debate over six o'clock closing in 1917, although differences over liquor issues had regularly divided MPs well before then, at times threatening the unity of the emergent Liberal Party in the 1890s. ${ }^{151}$ Similar divisions caused the Labour Party to drop liquor issues from its electoral platform by 1920 . The Party had previously supported state control although there were a variety of other views within the membership. ${ }^{152}$ This was to be almost the last time any major political party had a firm policy on alcohol issues that did not involve submitting them to a referendum or establishing a royal commission or select committee.

\footnotetext{
145 Fildred-Grigg, Pleasures, p. 63 and N7OYB 1990, p. 590, 661.

146. Eldted-Grigg, pp. 202, 282.

177 Sec, for cxample, Grigg, 'Citadels', p. 311.

$1+8$ (jrigg, p. 295.

1+5) Grigg, p. 295.

150 For example brewery head Arthur Mrers was a MHR from 1911 to 1921, R.C.J. Stone, Myers, Irthur Mielziner 1867 - 1926'. Dictionary of New Zealand Biography, updated 16 December 2003, URL: hrtp://www.dnzb.groxt.nz. It should be noted that Meyers always abstaincd in votes on liquor issues.

151 This is discussed in more detail in Chapter 3.

152 Grigg, 'Citadels', p. 322.
} 
Because of the spread and strength of views on alcohol issues within political parties, governments tended to adopt strategies designed to try to defuse intra-party debate. These strategies included appointing special select committees with a cross-party membership to inquire into the liquor laws, as was done in 1921 and 1960, and to make votes on liquor issues the subject of non-partisan 'conscience' votes. ${ }^{153}$ A further strategy was to try to remove such issues from the parliamentary sphere altogether, with two main tactics being used to this end. One was to turn the issue over to popular vote. As will be argued in Chapter 3, this tactic helped make politicians even more wary of taking firm decisions in relation to alcohol. Another strategy was to hand liquor issues over to an independent body to deal with. As a result, there were royal commissions on liquor in 1945 and 1974 and a 'working party' in 1986. In addition the National Efficiency Board looked at liquor issues in 1917, although as will be seen this was not a deliberate ploy on the government's behalf. This section gives a brief overview of all four inquiries.

While governments were often unwilling to be associated with particular stances on liquor issues, governmental advisors were less concerned about public opinion. This was particularly apparent in health and education. In 1921 the Health Department produced a pamphlet entitled Observations on Alcohol in Relation to the Human Body and Mind for distribution to school teachers. It expounded at length upon the dangers of alcohol and concluded that "the evils, individual and social, physical and moral, inseparably associated with the taking of alcoholic beverages far outweigh any considerations of its comparative harmlessness in restricted quantities'. ${ }^{154}$ The same year the chief inspector of primary schools reported that temperance instruction was a standard part of the school curriculum. 'Our chief aim should be to point out the great dangers coming from the use of alcoholic drinks, and to emphasise the evil effects of intemperance from the physical, mental and moral standpoints. ${ }^{155}$ The main source of policy advice to government on liquor regulation came from the Justice Department, which administered the liquor laws. It was the department's advice that eventually resulted in the setting up of the 1945 Royal Commission on Licensing. As was seen in the opening chapter, the department was an advocate for availability restrictions by that time, at least on the evidence of its

\footnotetext{
153 Select committees of course commonly consider and report back on legislative proposals, but these special committees were established to recommend legislative changes rather than considering those already introduced into Parliament.

${ }^{15+}$ Department of Health, Observations on Aliohol in Relation to the Human Body and Mind, Wellington, 1921.

155 'Report of the Chief Inspector of Primary Schools', Appendix I of Report on Primary Fiducation 1921, AJHR 1921, E2.
} 
submissions to the royal commission. However by the 1970 s the Justice Department tended to support a liberalisation of the liquor laws; the reform proposals it submitted to the 1974 Royal Commission on the Sale of Liquor were in many respects similar to those eventually adopted by the Labour government in $1989 .{ }^{156}$

The various independent inquiries into liquor legislation carried out by governmentappointed bodies and select committees are dealt with in more detail in subsequent chapters, but are briefly outlined below. The 1917 report by the National Efficiency Board (NEB) is covered in detail here because of its long-term ramifications. The Board was set up in the wake of the early twentieth-century drive for increased national efficiency discussed in Chapter 1 . The national efficiency drive became more pronounced after 1914 as an increasing share of labour and other resources were allocated to the war effort. One result was the establishment of the NEB by Defence Minister James Allan in 1917 to provide advice on a variety of issues including helping determine which industries were 'essential' and the extent to which industry could spare manpower for the war. ${ }^{157}$ In part this was to help deal with the problem facing military service boards when appellant conscripts claimed they could not be spared from the workforce. ${ }^{158}$ Although it was purely an advisory body, the NEB had a broad brief to examine issues of wartime efficiency throughout the economy. ${ }^{159}$

The board membership consisted of five voluntary appointees with business backgrounds, three of whom had a record of publicly supporting prohibition. ${ }^{160}$ Not surprisingly one of the NEB's first actions was to announce its intention to hold hearings and report on 'the liquor question'. ${ }^{161}$ The Boards hearings on the issue were held in private and some, for practical reasons, were attended by only one member. ${ }^{162}$ For example Board member James Frostick took evidence from three prohibitionists and a trade representative at a

\footnotetext{
${ }_{156}$ Justice Department Submission to the 1974 Royal Commission, Atchives New Zealand COM 21/8, submission 18.

${ }_{157}$ Report of the National Efficiency Board 1917, AJIIR 1917 I I.-43, Appendix 1, pp. 17-18.

158 Trik Olssen, 'Waging War: the Home Front 1914-1918' in Judith Binney, Judith Bassett, Frik Olssen, eds, The People and the Land; Te Tangata me Te Whenua: An Illustrated History of New Zealand 1820-1920, Wellington, 1990, p. 314. Conscripts could be excused from service if their work was deemed 'essential' but military service boards had trouble determining what this meant. See also Report of the National Efficiency Board 1917, pp. 4-5.

15\% Report of the National Ffficiency Board 1917, p. 16. Despite this broad brief there appears to be little evidence of the Board having much influence other than on liquor issues.

16il Report of the National Efficiency Board 1917, p. 1. The prohibitionist background of members is discussed below.

161 National Fifficiency Board Minute Book, Vol. 1, 2 February 1917 to 6 July 1918 in New Zealand National Fifficiency Board: Minutes, qMS-1528-1529, Alexander Turnbull Library, minutes for 26 April 1917.

162 National Efficiency Board Minute Book, Vol. 1, p. 76.
} 
closed hearing in Christchurch. ${ }^{163}$ The Moderate League, a lobby group set up to campaign for government ownership of the liquor industry, boycotted the hearings because of their secretive nature, later describing them as a 'star chamber'. ${ }^{164}$ The Alliance defended the NEB but expressed the hope that the evidence it collected would eventually be made public. ${ }^{165}$ Not only was the evidence never made public but the board's report on the liquor question was just two pages long. The report's lack of analysis to back up its far-reaching recommendations was also criticised by the Moderate League. ${ }^{166}$ Judging by the record of its proceedings, the full board spent less than 30 hours on hearings and discussions on liquor issues. ${ }^{167}$ In its report the NEB claimed to have heard some 60 witnesses, although many of these must have had minimal input judging by the little time the board spent on the hearings. Notably absent from the list of witnesses were representatives of the police - a significant oversight given that a long-standing criticism of prohibition was its unenforceability. ${ }^{168}$ Despite these faults, the pressure on the government that resulted from the release of the NEB's report led to the imposition of six o'clock closing in 1917 and significant legislative changes that almost resulted in New Zealand following the United States down the prohibition path. ${ }^{169}$

The prohibitionist background of board members has been largely overlooked by historians, with one claiming that the efficiency board 'constituted an unbiased tribunal and were free from all suggestions of personal interest'. ${ }^{170}$ The facts show otherwise. One member, James Gunson, was an active Methodist churchman who married into a prominent Auckland Methodist family. His company supported the Alliance by advertising in its regular newspaper. ${ }^{171}$ As mayor of Auckland from 1915 to 1925 Gunson was 'regarded by some as dictatorial, but was also skilled in persuasion', a skill he no doubt

\footnotetext{
163 L angtuard, 19 Nay 1917, no. 700 , p. 2.

$10+$ V anguard, 19 May 1917, no. 700, p. 2 and The Dominion, 3 August 1917, p. 7.

165 I anguard, 19 May 1917, no. 700, p. 2.

1 tor The Dominion, 3 August 1917, p. 7.

167 National Fefficiency Board Minute Book, Vol. 1. The Board interviewed witnesses in the week of 24-31 May 1917. I Iowever these hearings lasted only a few hours each day and members spent most of their time on other issues. The Board spent four brief sessions discussing the draft report in early July. The minute book contains no record of the Beard's discussions or its hearings. This secrecy may have resulted from the connection between the Board's work and the war in Lurope.

16s Sce, for example, N/PD 1881, volume 38, p.128.

167 Knowles, Promoting Prohibition', especially pp. 38-40 and Steven Early, 'The Six O'Clock Closing Debate', PostGraduate Diploma in History Rescarch Lissay, University of Otago, 1991.

170 . Nlan De La Mare, Drink or Drought: Liquor Licensing and the Probibition Movement, Invercargill, 1981, p. 36.

$171 \mathrm{Sec}$, for example, V anguard, 14 October 1911, p. 15.
} 
used to good effect in his role on the board. ${ }^{172}$ His mayoral pronouncements included attributing the poverty of some Auckland families partly to the expenditure of workmen's wages on drink. ${ }^{173}$ Another member, James Frostick, also supported the Alliance by advertising in V anguard. $^{174}$ According to one researcher both Frostick and Gunson were outspoken advocates of prohibition in 1919. ${ }^{175}$ A third member, William Hunt, was a staunch lifetime prohibitionist. As chairman and part owner of Wright Stevensons Limited he banned the company from handling alcohol. Hunt guided the company into a merger with the Gunson family seed-selling business in $1916 .^{176}$ He was an active member of the Alliance, and became president of another prohibition organisation, the National Efficiency League. ${ }^{177}$

The Board's report on the liquor question ignored the costs and difficulties of enforcement despite their obvious relevance to the issue of economic efficiency and made recommendations that went far beyond its mandate. Although it was established to report solely on wartime efficiency, the board recommended the on-going prohibition of alcohol in the interests of 'permanent national efficiency.' ${ }^{178}$ Despite its failings, the report provided a powerful weapon to prohibition advocates, who further shifted the thrust of their campaign to issues of economic efficiency. This was an important factor in gaining support for alcohol restrictions from outside of their traditional prohibition support base, particularly within the business community. ${ }^{179}$

The next significant external investigation into liquor was the 1945 Royal Commission on Licensing. The commission had its genesis in a 1939 recommendation from the

\footnotetext{
172 John Stacpoole, 'Gunson, James Henry 1877 - 1963'. Dictionary of Nen Zealand Biography, updated 31 July 2003 URL: http://www.dnzb.govt.nz/. Gunson came to national prominence in 1922 by demanding that Bishop Liston be tricd for sedition.

173 Cited by Linda Bryder, "Lessons' of the 1918 Influenza Epidemic in Auckland', NZJH, 16: 2, October 1982, p. 113.

174 See, for example, V anguard, 9 December 1911, p.3.

175 Tumey, "The New Zealand Alliance and Auckland', p. 151. 'The chairman of the efficiency board, William Ferguson, described himself as a temperance supporter who had been converted to prohibition, Vanguard, 2 November 1922, p. 10. Is Ferguson's family in Fingland were brewers, Gunson and his colleagues must have been particularly persuasive, F. Nigel Stace, 'Ferguson, William 1852 - 1935', Dictionary of New Zealand Biography, updated 7 July 2005, URL: http://www dnzb.govt.nz/.

176 William F Hunt, 'Hunt, William Duffus 1867 - 1939', Dictionary of New Zealand Biography, updated 31 July 2003, URI : http://www.dnzb.govt.na/.

177 Cocker and Murray, pp. 161 and 263, and Turney, New 7.ealand Illiance and Iuckland', p. 168. Some sources refer to National Efficiency Leagues'.

178 'Report of the National Fifficiency Board', AJHR 1917, H43, p. 12, and 'Report of the National Fefficiency Board on the Liquor Qucstion', AJHR 1917, H43. A.

${ }^{179}$ Knowles, 'Promoting Prohibition', pp. 23, 38-40.
} 
Department of Justice. Cabinet's go-ahead was delayed by the war but the National Party forced the government's hand by advocating a royal commission in the run-up to the 1943 election. As a result the Commission was established and many of its hearings were held while the war was still under way. Senior National MPs criticised the membership of the 1945 Royal Commission as being too representative of the factions from earlier decades. ${ }^{180}$ One commissioner, the Reverend Thomas Macky, was Chairman of the National Council of Churches, while another, Percy Coyle, was Secretary of the National Council for the Licensed Trade. ${ }^{181}$ The trade was also represented by Frederick Young, secretary of the hotel workers' federation. The Chairman, David Smith, was the son of a Presbyterian Minister and had been an active member of the Alliance when in his thirties. However he was a respected high court judge and his former prohibitionist views seem to have had little influence on his running of the commission. ${ }^{182}$

The commission held nationwide hearings from March to October 1945, and received submissions from or interviewed some 300 witnesses. Hearings were run very much along the lines of a court, with both the Alliance and the trade appointing legal counsel to represent their interests by interrogating witnesses and making opening and closing addresses. The main recommendations of the royal commission are discussed in detail in Chapter 5. The government implemented its proposal to establish a national body to oversee the application of the liquor laws but rejected the commission's controversial recommendation that it should buy the country's 42 breweries and its less controversial recommendation to allow the limited licensing of restaurants. While the commission recommended only minor changes to the restrictions on liquor sales to Maori, in a surprising move the government removed all such discriminatory provisions.

The third Labour government established another royal commission in 1973, honouring a manifesto commitment. The Royal Commission on the Sale of Liquor held hearings in 1973 and 1974 and received 226 submissions. ${ }^{183}$ However its work was hampered by a lack of clarity as to why it was being established. The Secretary for Justice remarked in a memo just prior to the 1972 election that 'the reason for this proposal completely escapes

\footnotetext{
${ }^{180}$ N/PD 1947, volume 278, pp. 602, 703.

181 Macky died shortly before the completion of the Commission's report.

182 For Smith's prohibitionist background sec V anguard, July 3, 1920, p. 9, and G.P. Barton, 'Smith, David Stanlcy 1888 1982', Dictionary of Nem Zealand Biography, updated 4 I pril 2003, http://www.dnzb.govt.11z/.

${ }^{183}$ Because some of its hearings were held in 1974 when the commission produced its final report, it will be referred to as the 1974 Royal Commission.
} 
me.... ${ }^{184}$ The terms of reference for the commission called on it to have regard to changes in New Zealand society and public attitudes towards alcoholic liquor since the 1945 Royal Commission'. ${ }^{185}$ The Justice Department interpreted this as a call for a comprehensive review of the liquor laws 'rather than the piecemeal approach of the past'. ${ }^{186}$ In the main the commission ignored this advice, its report being described by one researcher as 'disappointing' because 'many of the Commission's conclusions and recommendations were merely a statement of an existing situation and support for its retention'. ${ }^{187}$ The 1986 Working Party on Liquor was only slightly less blunt in its assessment: 'Unfortunately, the Royal commission was unduly constrained in its attempts to rationalise the liquor laws by its failure to reach a firm judgement on the effectiveness of legislative restrictions in controlling alcohol abuse. It proposed many changes designed to ameliorate what it saw as the unwanted impact of the existing law but those changes, when enacted, only contributed to the legislative morass. ${ }^{188}$ Despite such assessments the 1974 commission did make at least one suggestion that had significant and largely positive consequences; the incoming National government accepted its recommendation to allow people to bring their own wine to restaurants. National also accepted the commission's recommendations that sports clubs be allowed to obtain liquor licences and that ALAC be established to provide the government with ongoing advice on liquor issues.

The 1986 Working Party on Liquor was established amidst the reforming zeal of the fourth Labour Government although it operated largely independently from government. Former Chief Ombudsman Sir George Laking was appointed to chair it and the resulting report is sometimes referred to as 'the Laking report'. ${ }^{\text {(19) }}$ 'The working party undertook the first review of liquor legislation that sought to determine whether the existing legal provisions actually helped reduce problem drinking. It was the first official inquiry in

\footnotetext{
184 Quoted by Stace, p. 430.

${ }^{185}$ Royal Commission on the Sale of Liquor, pp, 9-10.

186 Justice Department Submission to the 1974 Royal Commission, Archives New Zealand COM 21/8, submission 18, p. 1.

${ }_{167}$ Mark Bogle, 'Objectives and Performance of Licensing Trusts in New /ealand', MMP Rescarch Paper, Victoria University of Wellington, 1983, p. 20. Nthough the 1974 commission's report ran to 365 pages including indexes, the size of the typeface used means the report was much briefer than the number of pages would indicate.

188 Working Party on Liquor, p. 13.

${ }^{187}$ The other members were Patricia Brockie, Nlan Dormer, Dorothea Horsman and Alma McMillan.
} 
New Zealand to acknowledge the importance of the availability theory, concluding that the theory 'has little explanatory power'. ${ }^{191}$

As previously mentioned, in the early 1960 s the government took some responsibility for liquor issues rather than handing them over to independent bodies or the popular vote. It set up a select committee that recommended that some restaurants could sell wine. ${ }^{191}$ The government accepted this recommendation despite the fact that both the Alliance and the trade had long opposed licensed restaurants. Over the next few years the government introduced other innovations that went against the views of the main lobby groups. However, like its predecessors, the second National government was unwilling to tackle the sacred institution known as the General Licensing Poll, as will be seen in the next chapter.

190 Working Party on J iquor, pp. 46-7.

191 The proceedings of an earlier select committee established in 1921 are ignored here, as none of the committee's recommendations found their way into law. 


\section{Chapter 3}

THE TYRANNY OF THE POLL

It was argued in the first two chapters that a reason why strict controls on alcohol were maintained in New Zealand and elsewhere was a belief that more availability means more drinking. However there were other reasons for the perpetuation of strict controls that were to some extent more specific to New Zealand. One was the persistence of the notion that alcohol was something so remarkable and special that issues concerning it could often not be dealt with by the conventional discussion and debate of the political process. Instead it became inculcated in the political consciousness that issues regarding liquor should be regularly submitted to public referendums. This chapter outlines how the use of regular liquor polls became so prevalent in New Zealand that a binding national referendum on prohibition, known as the General Licensing or triennial poll, was held in conjunction with almost every general election for 76 years. It argues that the opportunities for regular shows of numerical strength that liquor polls provided to the temperance lobby made politicians wary of initiating anything other than minor changes to the liquor laws. It also uses the results of the triennial poll as a source of data to track support for prohibition over time, forming a basis to discuss the changing fortunes of the temperance and prohibition movement during the twentieth century. The movement came closest to achieving its aims in December 1919, when prohibition failed by fewer than 1700 out of a total of nearly 550,000 votes to achieve the majority required for it to be carried in a binding national referendum.

\section{The Role of Referendums in New Zealand}

National referendums have traditionally taken place for two main reasons; a country's constitution requires them, or it allows citizens initiated referendums (or both). ${ }^{1}$ Thus referendums are compulsory in Switzerland, Australia, Ireland and Denmark if any changes to the country's constitution are proposed. Switzerland and Italy also allow

\footnotetext{
I In the 1990s the perceived threat to national sovereignty posed by the expanded role of the Furopean Union provided an additional role for referendums in European countries that traditionally made little use of them.
} 
binding referendums if sufficient petition signatures are collected. ${ }^{2}$ Not surprisingly these five countries are among the world's most frequent users of national referendums, as Table 3.1 shows. At the other end of the scale the United Kingdom, which has no codified constitution, had just one referendum prior to 1993.

Table 3.1: National Referendums in 15 Democracies to 1993

\begin{tabular}{|l|c|c|}
\hline & $\begin{array}{c}\text { Referendums to } \\
1993\end{array}$ & $\begin{array}{c}\text { Alcohol } \\
\text { Referendums }\end{array}$ \\
\hline Switzerland & 414 & 9 \\
\hline Australia & 44 & 0 \\
\hline New Zealand & 32 & 26 \\
\hline Italy & 31 & 0 \\
\hline Ireland & 18 & 0 \\
\hline Denmark & 16 & 1 \\
\hline France & 13 & 0 \\
\hline Norway & 5 & 2 \\
\hline Sweden & 5 & 1 \\
\hline Iceland & 4 & 1 \\
\hline Canada & 3 & 1 \\
\hline Finland & 1 & 1 \\
\hline Austria & 1 & 0 \\
\hline Belgium & 1 & 0 \\
\hline United Kingdom & 1 & 0 \\
\hline
\end{tabular}

Source: Butler and Ranney, Referendums, and LeDuc et al. ${ }^{3}$

New Zealand stands out in Table 3.1 because it lacks a codified constitution but, unlike Britain, has had a large number of plebiscites. Furthermore, these referendums have generally been initiated by governments rather than through constitutional requirements or citizens' action. ${ }^{4}$ One reason for the large number of referendums is the fact that the country is a comparatively long-standing democracy. But the main reason lies in the second column of the table - the extraordinary number of referendums the country has

\footnotetext{
${ }^{2}$ David Butler and Austin Ranncy, Referendums. Around the World: the Groming Use of Direct Democray, Washington D.C., 1994 , chapters 3,4 and 5.

${ }^{3}$ I awrence J.eDuc, Richard G. Niemi, Pippa Norris, eds., Comparing Democraties: Elections and Voting in Global Perspectives, Thousand Oaks, California, 1996.

+ The exceptions were the referendums held in 1967 and 1990 on extending the parliamentary term to four years. A referendum was required because the term of parliament was one of the provisions of clectoral law that were entrenched in 1956 so that a two thirds parliamentary majority or a referendum was required to change it, Neill Itkinson, Adventures in Democragy: A History of the I'ote in New Zealand, Dunedin, 2003, p. 168. Despite this provision, no referendum is required to add or remove entrenched provisions from those listed in the legislation, Richard Mulgan, Politics in New Zealand, Second Edition, Auckland, 1997, pp. 52, 282.
} 
had on alcohol. All but three of these 26 referendums were held under the General Licensing Poll instituted through the Licensing Amendment Acts of 1910 and 1918. These amendments provided for a poll on national prohibition to be held in conjunction with every general election. The law was specified so that the triennial poll would continue until prohibition (or, from 1919, state control) succeeded in gaining a majority vote or the government amended the law, as eventually happened when the poll was abolished in 1989. The General Licensing Poll was held an astonishing 23 times, 21 times with identical questions.

Even without the General Licensing Poll the country had a respectable eight referendums before 1994, more than all but seven countries in the table. However two of these were on alcohol issues and the others can largely be accounted for by periods of conflict and indecision within government. One year accounts for three referendums when in 1949 a divided Labour government with a small majority put three issues to the people. ${ }^{5}$ Neill Atkinson noted in his recent history of the vote in New Zealand that the three referendums 'reflected the declining fortunes of a Labour government that no longer possessed the confidence to make difficult or unpopular decisions.' ${ }^{6}$ In one poll the public were asked to endorse compulsory military training to avoid a Labour backbench rebellion. Both the government and opposition campaigned in support of the proposal so its passing was highly likely. ${ }^{7}$ Another period of multiple referendums was the 1990 s, when governments put three separate issues to the vote and legislated to allow nonbinding citizens initiated referendums. ${ }^{8}$ This was a time of political instability, with declining confidence in politicians, MPs switching allegiance between an increasing array of political parties, a change to the voting system, and an opportunistic coalition government in which one of the parties disintegrated.

While New Zealand has little in common with other countries in its use of governmentinitiated referendums, it has more in common with the states of Australia and provinces of Canada. As in New Zealand, all referendums in Canada and most state referendums in

\footnotetext{
5 The issues were off-course race betting, hotel closing hours, and compulsory military training.

6. Atkinson, Adventures in Democracy, p. 161.

${ }^{7}$ Keith Jackson, The Dilemma of Parliament, Wellington, 1987, p. 29.

8 There was a referendum on extending the parliamentary term in 1990, a two-stage referendum on the voting system in 1992 and 1993, and a postal ballot on compulsory superannuation in 1997. Three citizens initiated referendums were held in the late 1990s, Atkinson, Adventures in Democracy, pp. 208-217.

${ }^{9}$ Itkinson, Adventures in Democracy, pp. 206-227.
} 
Australia have been initiated by governments. The Canadian constitution prohibits citizens initiated referendums other than at a local government level, ${ }^{10}$ and no Australian state allows them." Although four Australian states provide for forms of compulsory constitutional referendums, these provisions have rarely been used. ${ }^{12}$ Tables 3.2 and 3.3 below compare the use of referendums in New Zealand with Canadian provinces and Australian states. The figures for New Zealand exclude all but the first of the 21 identical triennial polls. ${ }^{13}$ As can be seen, referendums on alcohol made up nearly 40 percent of those held in Australia and 70 percent of those held in Canada. Although none of the states and provinces exceeded New Zealand's use of referendums, two came close to doing so. In this context the country appears less of an outlier.

Table 3.2: Referendums in Canadian Provinces and New Zealand, 1892-1982

\begin{tabular}{|c|c|c|}
\hline & \begin{tabular}{|c|} 
Referendums to \\
1982
\end{tabular} & $\begin{array}{c}\text { Alcohol } \\
\text { Referendums }\end{array}$ \\
\hline New Zealand* & 9 & 6 \\
\hline British Columbia & 9 & 5 \\
\hline Alberta & 7 & 4 \\
\hline Manitoba & 7 & 6 \\
\hline Saskatchewan & 6 & 4 \\
\hline Ontario & 5 & 5 \\
\hline Prince Edward Island & 4 & 4 \\
\hline Newfoundland & 3 & 1 \\
\hline Nova Scotia & 3 & 3 \\
\hline Quebec & 2 & 1 \\
\hline
\end{tabular}

* NZ figures count the General Licensing Poll only once.

Source: Boyer, Lawmaking, pp. 39-41 and Heron, Booze.

$10 \mathrm{~J}$. Patrick Boycr, I ammaking by the People: Referendums and Plebiscites in Canada, Toronto, 1982, especially pp. 34-37 and Heron, Booze, p. 171.

11 Geoffrey Walker, Initiative and Referendum: The People's Law, Sydney, 1987, pp. 19-21.

12. Walker, Initiative and Referendum, p. 20.

13 It could perhaps be argued that the General Licensing Poll after 1919 was really one referendum repeated numerous times rather than 21 separate referendums. The argument has more validity when applied to the period after 1935 when prohibition was clearly a dead issue. 
Table 3.3: Referendums in Australian States and New Zealand, 1901-1993

\begin{tabular}{|l|c|c|}
\hline & $\begin{array}{c}\text { Referendums } \\
\text { to } 1993\end{array}$ & $\begin{array}{c}\text { Alcohol } \\
\text { Referendums }\end{array}$ \\
\hline New Zealand* & 12 & 6 \\
\hline New South Wales & 11 & 5 \\
\hline Victoria & 7 & 4 \\
\hline Western Australia & 7 & 2 \\
\hline Queensland & 6 & 2 \\
\hline South Australia & 5 & 1 \\
\hline Tasmania & 3 & 1 \\
\hline
\end{tabular}

* NZ figures count the General Licensing Poll only once.

Source: Butler and Ranney, Referendums, pp. 167-8.

Two Australian states, Victoria and Western Australia, passed legislation that in theory provided for regular New Zealand-style prohibition polls. In Victoria, polls were to be held every eight years after 1922 but in fact only two were held before the provision was abolished in $1946 .^{14}$ Similarly only two of Western Australia's legislated five-yearly polls were ever held. ${ }^{15}$ Unlike these Australian examples, New Zealand's triennial prohibition polls were only twice cancelled or postponed. ${ }^{16}$ Furthermore, they were binding on the government. Only one other binding national referendum has ever been held in New Zealand - the 1993 referendum on the electoral system. ${ }^{17}$ All other national referendums were glorified opinion polls, which governments have been entitled to ignore and sometimes have done so. ${ }^{18}$ For this reason the Statutes Revision Committee deliberately substituted the wording 'I favour' for 'I vote for' on the ballot paper for the 1967 referendum on hotel hours. Committee member Martyn Findlay explained the reason for the change: We felt that this was not a mandatory order on Parliament by the body of

\footnotetext{
${ }^{14}$ lewis, $A$ Rum State, pp. 66-7, 73, 77.

${ }^{15}$ Lewis, A Rum State, pp. 68-9 and Butler and Ranney, Referendums, pp. 167-8.

16 'The General Jicensing Poll was not held in 1931 or 1951.

17 F.M. Brookfield, 'Referendums: I.egal and Constitutional Aspects', in . Nan Simpson, ed., Referendums: Constitutional and Political Perspectives, Occasional Publication no. 5, Department of Politics, Victoria University of Wellington, 1992, pp. 9-10. Of course any government has the power to override even a binding teferendum, although potentially at great political cost.

18 Governments ignored the three highly-flawed referendums held under the Citizen's Initiated Referendums Ict, Atkinson, Adventures in Democray, p. 217. Technically it could be argued that the referendums held in 1967 and 1990 on extending the parliamentary term were binding in that the 'no' vote in these referendums bound the government to inaction. I [owever a 'yes' vote could have been legally ignored by the government.
} 
the electorate, but rather should be regarded as an expression of opinion by the people, intended to guide Parliament in the course of action it should adopt. ${ }^{, 19}$

Apart from issues relating to alcohol, referendums were rarely used in New Zealand at either a national or local level until the 1990s. Under the Local Elections and Polls Act 1908 , local polls could be held on the resolution of a local authority or a petition of ratepayers, although nothing in that Act required such polls to be held. ${ }^{21}$ The provisions were used occasionally through legislation that gave local authorities the option of holding ratepayer polls on which day of the week would be a 'half-holiday' with respect to shop opening hours. ${ }^{21}$ New Zealand law has also allowed, or in some cases required, ratepayer polls on capital works proposals. ${ }^{22}$ At the national level, until the 1990 s there had been referendums on just three subjects not related to liquor. ${ }^{23}$

\section{The Origins and Effects of Liquor Polls}

The holding of 26 national referendums on issues relating to alcohol is a phenomenon that appears in need of explanation. The use of direct democracy to further prohibitionist aims had its origins in the United States. ${ }^{24}$ By the 1830 s the growing American temperance movement was shifting from moral suasion to legal and political action to encourage abstinence from strong drink. Under the influence of 'no-licence' advocates, annual town meetings in Massachusetts began to vote against issuing liquor licences. The trend known as 'local option' extended to county and then state-wide campaigns, with votes increasingly held by ballot or in legislatures rather than in public meetings. ${ }^{25}$ Maine was the first state to attempt to ban all liquor sales in 1851, shortly followed by 12 other states and territories. ${ }^{20}$

\footnotetext{
19 N7PD 1967, volume 351, p. 1376.

20 J ocal Filections and Polls . Ict, New Zealand Statutes 1908, pp. 762-3.

${ }^{21}$ John Martin, Holding the Balane: A History of New Zealand's Department of Labour 1891-1995, Christchurch, 1996, pp. 51 55 , especially footnote 177.

22 G.I. Wood and Chris Rudd, The Politics and Government of Nem Zealand; Robust, Innovative and Cballenged, Dunedin, 2004, p. 199.

23 Is outlined on p. 63 the subjects were peacetime conscription, racehorse betting, and the extension of the parliamentary term.

24 The term 'direct democracy' is used to describe situations in which decisions are made directly by the vote of the people rather than through elected representatives.

25 For a therough account sec Tyrrell, Sobering Up, chapters 9 and 10.

26 Tyrrell, Sobering Up, pp. 3, 244-5, 254.
} 
The use of local democratic action to close down liquor outlets appealed to temperance

advocates in the United Kingdom. Many were suspicious of the power placed in the

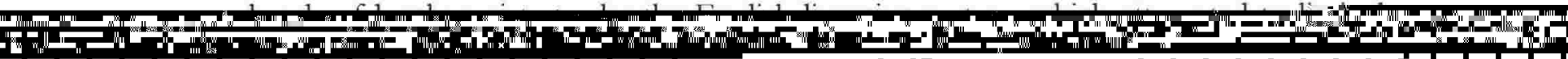

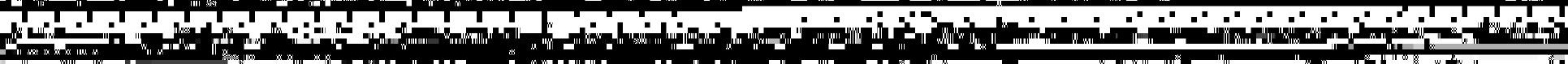
.

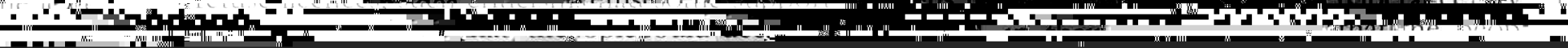

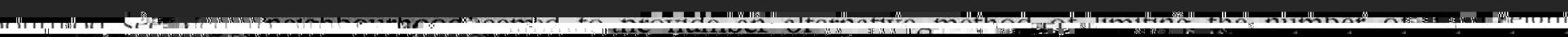

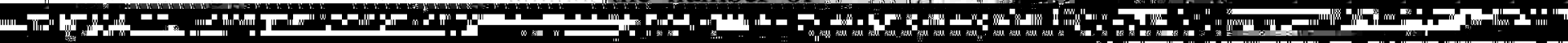

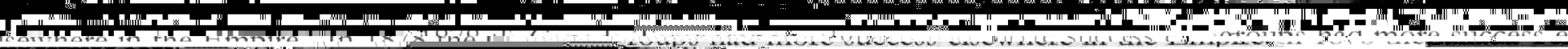

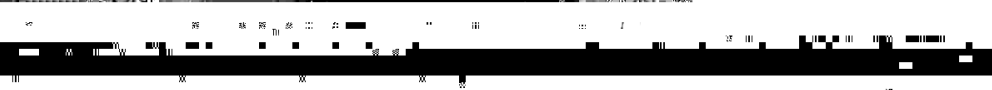
The

$\mathbf{m}$

19...

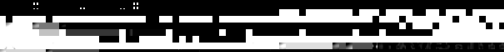

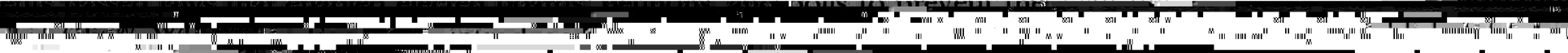

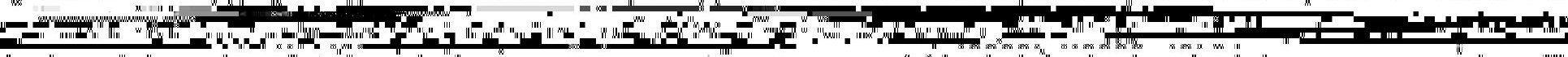

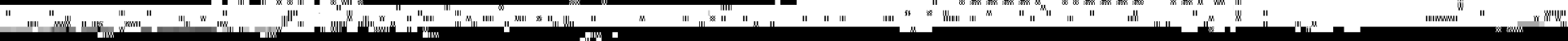

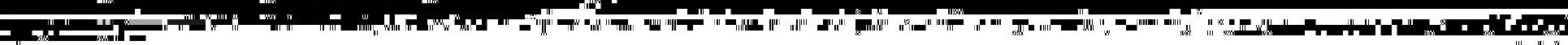

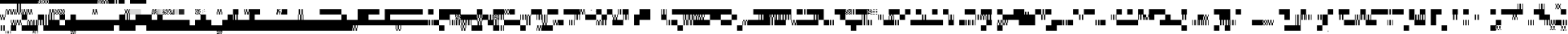

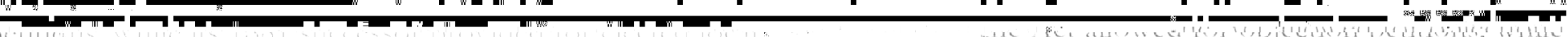

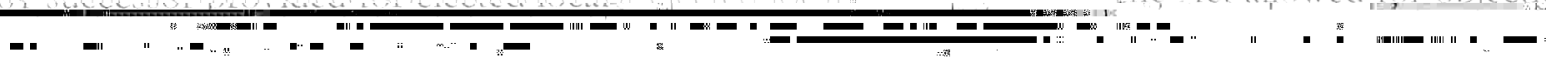
sis

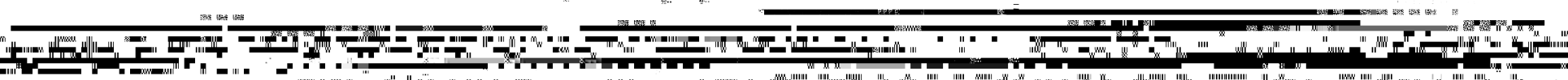

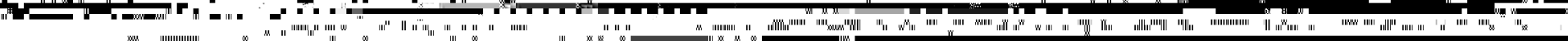

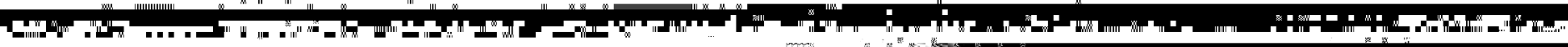

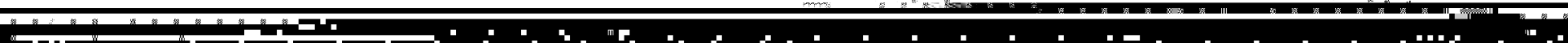

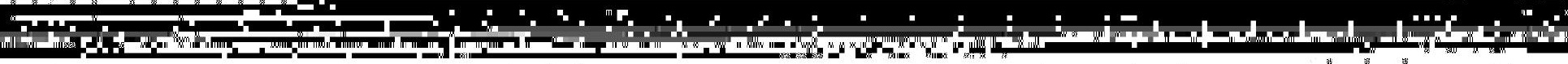

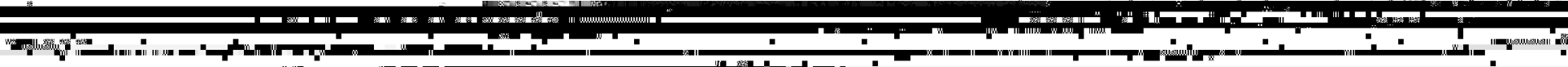

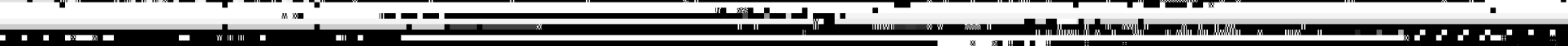

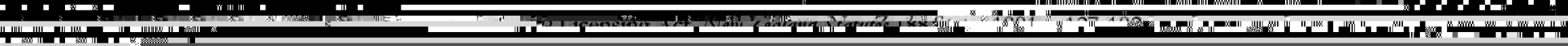
(1)

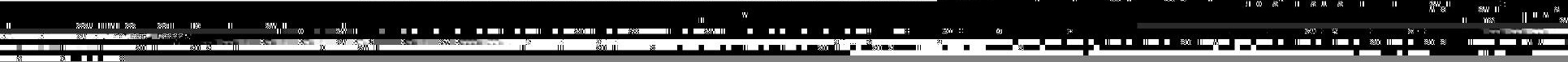


1893 Supreme Court ruling prevented licensing boards from closing all liquor outlets in their area. As a result prohibitionists shifted their focus to campaigning for direct veto rather than trying to stack licensing boards with supporters. ${ }^{34}$ The direct veto campaign had the support of the New Zealand Alliance, formed in 1886 with the aim 'to secure for the people the legal direct power to veto the liquor traffic'. ${ }^{35}$

Prohibitionists made significant gains once the Liberals came to power. The Liberals were strongly motivated by a desire to ensure the country was free of Old World evils such as crime and destitution and it is therefore not surprising that some of its MHRs supported temperance ideals. ${ }^{36}$ After the death of John Ballance in 1893 his interim replacement Seddon had an insecure grip on power. His main rival, Robert Stout, proposed a local option bill which, according to David Hamer, was aimed at usurping Seddon's leadership by gaining the political support of the prohibitionist faction within caucus. ${ }^{37}$ However Seddon outmanoeuvred Stout with his own compromise local option bill. The bill conceded much to the prohibitionists by providing for some or all of each electorate's bars to be closed through a public vote. ${ }^{38}$ However it also made concessions to their opponents by requiring a three-fifths majority for an electorate to go completely dry. ${ }^{39}$ Furthermore, if fewer than half enrolled voters turned out to vote then the poll in that electorate was declared void, a provision that worked to the advantage of those who favoured the status quo." As well as giving something to both factions, ' $[\mathrm{b}] \mathrm{y}$ conceding local option Seddon had hoped to remove the question from the arena of parliamentary politics to the separate licensing poll'.41 He thus hoped that liquor issues would no longer be a source of division within the Liberal party.

\footnotetext{
34 Hamer, The New Zealand Liberals, pp. 115-118 and McKimmey, 'The Temperance Movement in N'', pp. 4446.

35 Cocker and Murray, p. 57.

36. I Iamer, The New Zealand Liberals, pp. 54-59.

37 Hamer, The Nen Zealand Liberals, pp. 115-119. Although Hamer portrays Stout's actions as opportunistic, Stout had backed a local option bill as early as 1877, NZPD, volume 20, pp. 475-8.

38. Alcoholic Liquors Sales Control Act, New Zealand Statutes 1893, pp. 127-140.

39. Nlcoholic J iquors Sales Control Ict, Nem Zealand Statutes 1893, p. 135. This provision was far from one-sided, as a three-fifths majority was also required for a dry electorate to go wet again. Furthermore, if no-licence failed to achieve the required majority in an electorate then votes for this option were added to those for a reduction in licence numbers, which only required a bare majority to be carried.

t0. Mcoholic liquors Sales Control Ict, New Zealand Statutes 1893, p. 136. 'The provision requiring a 50 percent turnout lasted only a year.

+1 I lamer, The New Zealand Liberals, p. 118.
} 
Until the mid 1890s the public had shown little interest in liquor polls and licensing board elections. In 1882, for example, 72 percent of licensing board elections were uncontested or failed to produce a result, presumably because of a lack of candidates or insufficient votes being cast. ${ }^{42}$ Just 16 percent of voters turned out in the 1890 local option polls. ${ }^{43}$ Many districts did not even bother to hold elections and polls. ${ }^{44}$ The turnout in the first local veto poll in 1894 was higher than in licensing board elections but was still only 33 percent. ${ }^{45}$ In order to boost turnout Parliament amended the Act so that polls would coincide with general elections, which had official turnouts of 75 percent in 1893 and 80 percent in $1890 .^{46}$ The move was successful in getting voters to take an interest in liquor polls - perhaps too successful, for over time polls and alcohol came to be closely associated in the minds of voters and politicians alike.

Seddon's compromise appeared to have sufficiently mollified the pro and anti prohibition factions within caucus to ensure party unity, but it was only temporarily successful in removing the issue from parliamentary politics altogether. The 60 percent majority requirement was a source of on-going irritation to many prohibitionists who campaigned to have it reduced to a bare majority. They were also buoyed by a rising no-licence vote, numerous hotel closures and 12 electorates voting to ban alcohol sales by 1908 , and therefore pressurised the government for a referendum on national prohibition. ${ }^{47}$ They were supported by those disillusioned with the effect of no-licence, for the liquor industry did all it could to facilitate the legal importation of alcohol into dry districts for personal use and illegal liquor sales were allegedly rife. Prime Minister Joseph Ward felt compelled to act and began a series of negotiations with the Alliance and the brewer-dominated liquor industry. A national prohibition poll had some attractions for the brewers, who were searching for a way to halt the seemingly inexorable rise of no-licence support. They felt that if no-licence votes contributed to a national prohibition vote, moderate voters may be deterred from voting no-licence. ${ }^{48}$ This was consistent with the actions of liquor interests in 1902 when they supported a proposal to outlaw the possession as well as the

\footnotetext{
${ }^{2}$ Figures calculated from . IJI IR 1883, II.28.

43 Figures calculated from . YJHR 1890, H.30, p. 7.

"H McKimmey, 'The Temperance Movement in NL', pp. 43, 60-61, 91 and Eldred-Grigg, Pleasures, p. 189.

t5 Cocker and Murray, p. 77. Elected licensing boards also attracted little interest. Most elections were uncontested and the voter turnout in contested elections was often tiny, PRCJ, p. $6584 \mathrm{\Lambda}$.

Ho. Atkinson, Adventures in Democray, pp. 101,244.

47 Cocker and Murray, pp. 99-101.

ts Newman, New Zealand's Vote for Prohibition in 1911', pp. 54-5.
} 
sale of liquor in dry districts in the belief that such a restriction would make no-licence less palatable to the supposed moderate voter. ${ }^{49}$

After a complex series of negotiations Ward delivered something unexpected; an Act that provided for two separate licensing polls to be held in conjunction with every general election from 1911, one for local no-licence and the other for national prohibition. ${ }^{50}$ The reduction option, seen as an unsatisfactory compromise by many prohibitionists, was removed from the local ballot paper. National prohibition achieved a remarkable 56 percent support in the 1911 poll, but this was insufficient to pass the three-fifths threshold that applied to both national prohibition and local no-licence votes. Surprisingly, the average no-licence vote fell to under 50 percent after having risen in every previous poll. The brewers were clearly wrong; when given a choice between imposing no-licence on their neighbours or national prohibition on the country, many voters opted for the latter. The no-licence vote fell again in 1914 and the vote for national prohibition also fell to less than 50 percent. $^{51}$ No additional electorates voted no-licence after 1908 and forced bar closures therefore ended. The scheduled 1917 General Election and its accompanying licensing polls were postponed for the duration of the war, but that same year the National Efficiency Board produced its report discussed in Chapter 2. Although several Board members were prohibitionists they did not recommend that the government legislate immediately to introduce prohibition. Instead the Board recommended that a special poll be held as soon as possible on the question of national prohibition, for 'prohibition is a people's question, and should be determined only by an expression of the voice of the people. ${ }^{52}$ The link between prohibition and polls was clearly already well established.

The Board's report received much attention and businessmen formed National Efficiency Leagues in support of its recommendations. ${ }^{53}$ The Alliance launched a petition calling for a special referendum on prohibition to be held by the end of 1918. The petition claimed an improbable 242,000 signatures. It was met by a liquor trade petition calling for the special poll on prohibition with compensation, to be held in conjunction with the next

\footnotetext{
49 Grigg, 'Citadcls', pp. 216-221 and Mcl_auchlan, The Story of Beer, p. 98.

50 Newman, New Kealand's vote for Prohibition in 1911', p. 58.

51 No-licence polling figures for 1896 to 1908 are from Newman, p. 66. Those for 1911 and 1914 were calculated from Cocker and Murray, p. 271.

52 'Report of the National Efficiency Board on the Liquor Question', AJHR 1917, H43. I, p.12.

${ }^{53}$ Turney, "The New Zealand Alliance and Auckland', p. 153.
} 
general election and with the ballot paper to include a third option of state control of the liquor industry. ${ }^{54} \mathrm{~A}$ state control option had been advocated by various groups, including the Anglican Church, since the late nineteenth century and an organisation called the New Zealand Moderate League had lobbied for its inclusion in the General Licensing Poll ballot paper since $1914 .^{55}$ The Labour Party also supported state control, at least until 1919. ${ }^{56}$ By 1918 the proposal had the support of the liquor industry, which presumably hoped that state control would take votes from prohibition.

The trade petition claimed an even less plausible 306,000 signatures, meaning almost every registered voter in the country had supposedly signed one of the two main petitions. The Labour Party presented its own petition with a modest 1830 signatures calling for a fourissue ballot paper - continuance, prohibition with and without compensation, and state control - with the result to be decided by preferential voting. ${ }^{57}$ Late in 1918 the Government came up with a compromise measure which included aspects of all these proposals. In December 1918 Parliament passed the Licensing Amendment Act that provided for a special national licensing poll in April 1919 and new rules for the poll to be held with the December 1919 general election. Two national referendums on prohibition were therefore held within eight months. ${ }^{58}$ Among the changes made in 1918, prohibition could be introduced by a bare majority rather than requiring three-fifths of the vote, and once introduced it would become permanent; there would be no guaranteed future polls by which the public could reverse the decision. ${ }^{59}$ However if neither prohibition nor state control was carried in 1919 there would be further referendums in conjunction with every general election until the status quo ('National Continuance)' was overturned or the law amended. As a concession to the liquor industry the government abolished local veto and agreed to provide $f_{4} .5$ million in compensation if prohibition was carried in the special

\footnotetext{
5t Dominion, 4 December 1918, p. 6. Prime Minister William Massey summed up the background when introducing the licensing Amendment Bill to Parliament.

55 Dominion, 3 . August 1917, p. 7, Anthony Grigg, ‘Viable Option or Vote Splitter?', Comment, November 1981, no. 14, pp. 15-19, and 'lurney, "I 'he New Zealand Mlliance and Iuckland', p. 155.

56 Grigg, 'Citadels', p. 322, Bollinger, 1967, p. 85 and Turncy, 'The New Zealand Alliance and Auckland', p. 155.

57 Daminion, 4 December 1918, p. 6.

5s Licensing Amendment Act, New Zealand Statutes, 1918, pp. 94-122. See also Atkinson, Adventures in Democrag:; p. 129. When parliament passed the 1918 legislation MHRs did not know there would be a general election in December 1919 as the scheduled 1917 election had been postponed because of the war.

59. Nlthough, as with any other legislated change, prohibition could be overtumed by parliament, the history of this issue indicates that this would have been a tortuous process inevitably involving a referendum.
} 
April 1919 licensing poll. ${ }^{60}$ There would continue to be no compensation in the event of a majority prohibition vote in the General Licensing Poll, but Parliament agreed to add a 'State Purchase and Control' option to the ballot paper as some had advocated. ${ }^{61}$

There was much controversy at the time and since over whether the changes to the General Licensing Poll introduced in 1918 favoured prohibitionists or the liquor industry, with one researcher describing the changes as 'a one-sided deal, weighted in the liquor trade's favour'. A similar view was shared by two Wellington newspapers in 1919. ${ }^{63}$ The liquor industry clearly hoped - and the Alliance feared - that some prohibitionists would see state control as a moderate alternative to prohibition. The evidence shows that both groups were wrong and the Alliance wasted valuable resources publishing propaganda against state control in 1919 and 1922. ${ }^{64}$ Few if any prohibition supporters switched their votes to state control until 1946. When there was no state control option in April 1919, continuance polled 51 percent. In the December 1919 referendum the newly-introduced state control option polled six percent, the continuance vote fell by seven percentage points, and the prohibition vote increased. Clearly it was continuance voters who opted for state control, while prohibitionists understandably showed no interest in it. In the lead up to the 1922 poll the Moderate League and the Anglican Church placed 11 advertisements in the Dominion newspaper calling people to vote state control. ${ }^{65}$ Despite their campaign this option attracted no more voters in 1922 than it had in $1919 .^{66}$ Figure 3.1 below shows that it was not until the 1946 poll, taken shortly after the Royal Commission on Licensing had recommended nationalisation of the liquor industry, that state control appeared to attract any prohibition supporters. The trebling in the state control vote between 1935 and 1946 appeared to be almost entirely at the expense of continuance. When the state control vote returned to its previous level in 1949, the fall of eight percentage points was mirrored by an equivalent rise in the continuance vote.

\footnotetext{
${ }^{60}$ Jicensing Imendment Act, New Zealand Statutes, 1918, pp. 94-122, Part I and section 22. The National Ifficiency Board recommended compensation to the industry but not to workers made uncmployed by prohibition.

61 The official options from December 1919 onwards were National Prohibition, National Continuance (ie, the status quo), and State Purchase and Control. These will be referred to simply as prohibition, continuance and statc control.

62 'Turncy, "The New Zcaland Alliance and Auckland', p. 160. See also the concluding chapter.

63 The Evening Post, 18 December 1919, p. 6, The Dominion 18 December 1919, p. 8.

6. The Dominion, 2 December 1919, p. 3 and 13 December 1919, p. 10. The Nlliance also placed anti state control advertiscments in 1922.

65 The Dominion, all issues 1 November to 7 December 1922. There were 20 advertisements for prohibition and 17 for continuance over the same period.

(6) N $2 O Y B 1920$ and 1923.
} 
Clearly it was continuance supporters who had a tendency to switch votes to and from state control, while disillusioned and disheartened prohibition supporters opted for continuance. When voters deserted prohibition between 1925 and 1935 they shifted allegiance to continuance rather than to state control.

Figure 3.1: Percent Voting for Continuance and State Control, 1919-1949

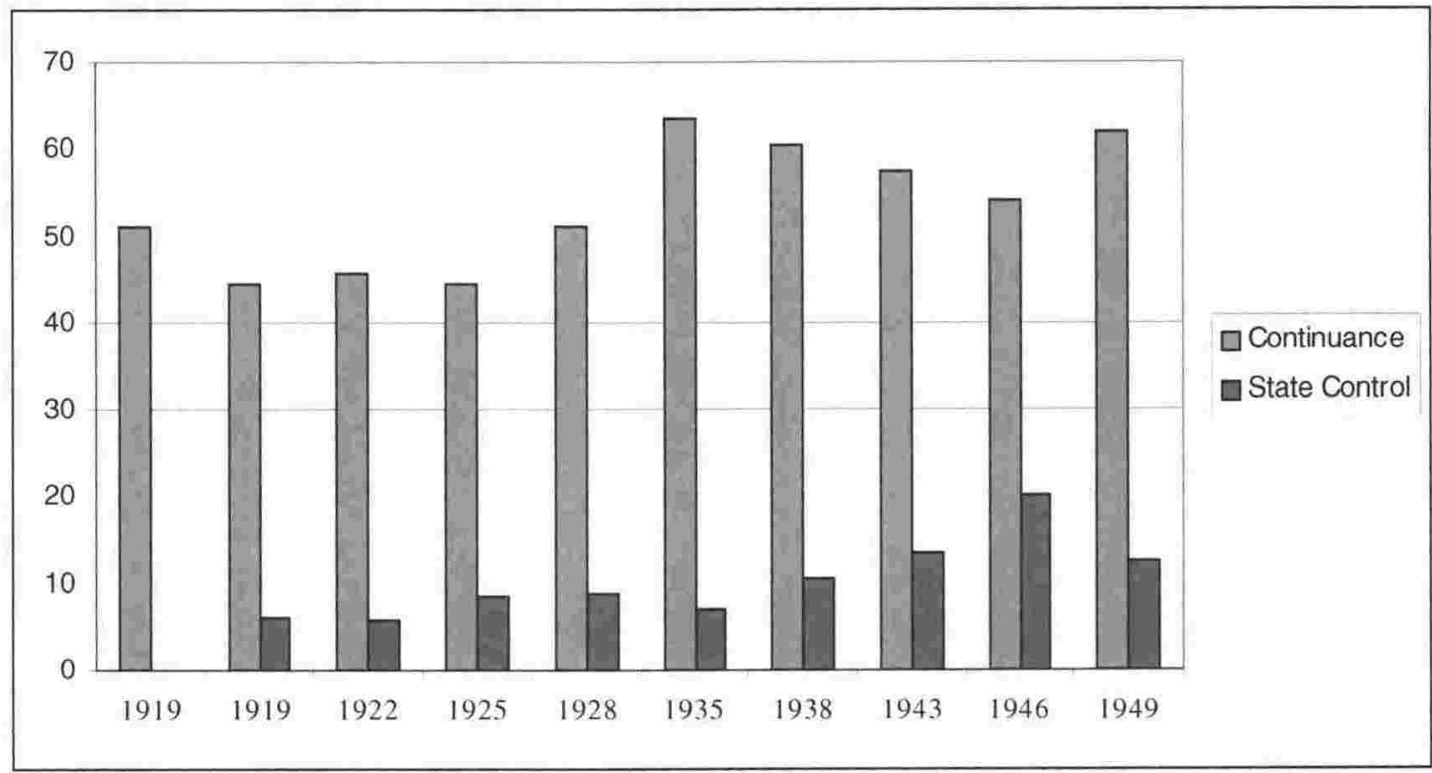

Source: NZOYB 1920, 1923, 1926, 1929, 1936, 1939, 1947, 1950. Note that the State Control option was first offered in the December 1919 poll.

Another legislative change in 1918 that could be seen as harming the prohibitionist cause was the ending of local veto. However at the time the loss cannot have seemed great, for the no-licence vote declined after 1908 and there was no longer an option to vote for a reduction in licences. As was seen earlier, once a separate national prohibition poll was provided for in 1911 the vote for local no-licence dropped below 50 percent, and fell again in 1914. ${ }^{67}$ Voters lost interest in no-licence when they had a national prohibition alternative. The removal of local veto enabled prohibitionists to concentrate their efforts on trying to secure national prohibition rather than mounting numerous local campaigns that produced no results.

A common complaint of prohibitionists was that only 12 districts had been able to go dry because of the allegedly undemocratic 60 percent majority requirement. The Alliance had

\footnotetext{
67 ligures calculated from Cocker and Murray, p. 271. There were separate voting forms for national prohibition and local no-licence.
} 
campaigned for a bare majority. ${ }^{6.8}$ However the three-fifths requirement had been put in place for reasons other than political expediency. Firstly, it was considered that a vote that would put publicans out of business without compensation should require a significant majority vote. William Pember Reeves made this point when debating licensing polls in 1893. He outlined the process of discussion, debate and submission that any proposals originating in parliament must go through. 'Can one imagine that there is anything in that process in the slightest degree analogous to the power of confiscation of a great mass of property by a simple vote and a bare majority?' he asked. ${ }^{69}$ A second reason for the requirement was to provide stability; otherwise it was possible for individual electorates to fluctuate between being wet and dry in successive polls. ${ }^{70}$ Significant fluctuations in nolicence voting was already apparent in some electorates by 1905 , and some prohibitionists recognised that the three-fifths majority could work in their favour by preventing dry areas from going wet again. ${ }^{71}$ Although the ending of local veto in 1918 made the stability argument irrelevant, in 1945 the Alliance argued for the retention of the 60 percent requirement for restoration of licences in dry districts. ${ }^{72}$ The reason for this change of heart is obvious; by 1935 it was only the 60 percent requirement that prevented half of the dry areas from restoring licences. ${ }^{73}$

While the inclusion of state control on the ballot paper and the removal of local nolicence were of little or no benefit to the liquor industry, other changes introduced in 1918 went against the industry's interests. Under the 1910 Act the industry had been granted four years grace if prohibition was carried, during which time a further poll would normally be held that would give voters the opportunity to change their minds. ${ }^{74}$ The 1918 Act required prohibition to be introduced within six months if carried, with no opportunity for future polls (barring Government intervention) if voters rejected continuance. Allowing the introduction of prohibition within six months without compensation has been somewhat melodramatically described by political scientist John

\footnotetext{
68 Grigg, 'Citadels', p. 257, Cocker and Murray, pp. 94, 100.

(9) NZPD 1893, volume 80, p. 391.

${ }^{70}$ Working Party on Liquor, p. 85.

71 Grigg, 'Citadels', pp. 254-7.

72 PRCL, pp. 1927-8.

${ }^{73}$ Report RCl, pp. 209-10.

7 Cocker and Murray,p. 119.
} 
Prince as a 'draconian provision, as ruthless as anything done under totalitarian regimes'. 75 Overall the changes to the General Licensing Poll introduced in 1918 acted against the interests of the liquor trade by making prohibition a far greater likelihood than had been the case under the previous rules.

Once in place the General Licensing Poll proved remarkably difficult to budge. To quote Prince again; "There can have been few longer running instances of the power of single issue politics than the persistence of this referendum. ${ }^{, 76}$ As Figure 3.2 (p. 82) shows, the numbers voting for prohibition were consistently around 250,000 until the 1960s. Prohibitionists were a minority, but a minority with strong convictions who relished the three-yearly show of strength that the triennial poll provided. The liquor industry regularly proposed that the triennial poll should be abolished or at least held less frequently, but without success. ${ }^{77}$ The fear of upsetting temperance supporters by abolishing a poll that regularly validated their importance was too great for governments of all persuasions. Even independent bodies seemed cowed by the prohibition lobby on this issue. The 1945 Royal Commission recommended the poll be retained because 'about 30 percent' of people still voted for prohibition. ${ }^{78}$ The 1960 select committee was divided on the issue but thought abolition of the triennial poll might be able to be considered 'at a suitable future time'.

A major result of holding liquor polls in conjunction with every general election from 1896 is that polls and liquor came to be inseparable in the mind of voters and politicians alike. Seddon's efforts in the 1890 s to remove liquor issues from parliament had 'cemented into New Zealand's political consciousness the notion that alcohol was so sensitive a subject that issues concerning it ought to be regularly put to the people in referendums'. ${ }^{80}$ Regular polls reinforced the idea that liquor was 'something uniquely wicked, or at least something remarkable and special. ${ }^{81}$ The Alliance played on this idea,

\footnotetext{
75 John Prince, 'Look Back in Amber: The Gencral Licensing Poll in New 'Kealand, 1919 - 1987', in Political Science, July 1996, p. 51.

${ }^{76}$ Prince, 'J Jook Back in Amber', p. 56

$77 \mathrm{Sec}$, for cxample, Report RCl, p. 204.

78 Report RCL, p. 204. In 1946, the year the commission released its report, the prohibition vote fell to 26 percent and continued to fall in subsequent polls.

${ }^{79}$ Report of the Committec on Licensing, AJHR 1960, 1.17, pp. $27-8$.

so Prince, 'look Back in Amber', p. 55.

81 Justice Department submission to the Royal Commission on the Sale of Liquor 1974, p. 31.
} 
arguing in 1945 that the fact that no national poll had ever been held on any other subject showed that alcohol was indeed a special case. ${ }^{82}$ In the 1970 s a Justice Department official noted that the relation of polls and liquor in New Zealand has become a tradition'. ${ }^{83}$ In 1983 a standard text on the liquor laws stated that 'even today it is often considered axiomatic that on liquor matters, the people should have the right of referendum', ${ }^{84}$

A national predilection for dealing with liquor by way of local and national polls continued throughout the twentieth century. As outlined earlier, local option polls were supplemented by national prohibition referendums from 1911, of which 24 were held over 76 years. Twenty-one of these were identical polls held in conjunction with almost every general election between 1919 and 1987 through the revised triennial poll introduced in 1918. ${ }^{85}$ Although local veto was abolished in 1918, for much of the century over ten percent of the population voted in triennial restoration polls. ${ }^{86}$ The National Party's 1943 election platform included a proposal for a royal commission on licensing, with the commission's recommendations to be specified in such a way that they could be easily put to the public vote in a series of referendums. The referendum results would then guide the government in any legislative change. ${ }^{87}$ In 1947 National had not given up on this idea, for it advocated that the five main recommendations of the 1945 royal commission should be the put to the people to decide upon. ${ }^{88}$ In 1948 the government introduced a provision allowing local objection polls on new liquor licences. ${ }^{89}$ From 1949 local communities were asked if they wanted a community trust to operate any new licences that were issued, particularly when a previously dry area went wet. ${ }^{90}$ Referendums on hotel closing times were held in 1949 and 1967. ${ }^{91}$ The National Party's

\footnotetext{
\$2 PRCl, pp. 1926-7.

${ }^{83}$ Ney Zealand Royal Commission on the Sale of L Lquor in New Zealand: Transcripts, volume 1, p. 205.

84 Southwick ct al, The Liquor Laws of New Zealand, p. 2.

85 The 1931 triennial poll was cancelled as an austerity measure with the agreement of the Alliance and the industry. No poll was held in conjunction with the 1951 snap election.

80. The restoration polls held in dry districts enabled voters to restore licences. A 60 percent majority was required for restoration.

87 Auckland Star, 28 August 1943, p. 7.

88 N'/1'D 1947, volume 278, p. 603.

89 Licensing Amendment Act, New Zealand Statutes 1948 volume 2, pp. 948-951.

90 Southwick et al, The Liquor Lans of New Zealand, p. 5, and Bollinger, 1967, pp. 114-6. Twenty-two polls had been held on trust owncrship by 1955 .

9) These are discussed in detail in Chapter 5.
} 
1957 election manifesto included a proposed referendum on allowing licensed restaurants. ${ }^{92}$ The 1974 Royal Commission suggested national referendums on whether to allow Sunday liquor sales and on whether the General Licensing Poll should be abolished..$^{33}$ Liquor polls continued into the twenty-first century, most recently in November 2004 when the residents of Ashburton and Geraldine voted to remove a licensing trust monopoly on liquor sales. ${ }^{94}$

It was not just habit and the fear of a prohibitionist backlash that helped keep the triennial poll in place. The inclusion of the state control option on the ballot was also a factor. The 1945 Royal Commission on Licensing proposed to use the poll to further its recommendation for state ownership of the breweries. ${ }^{95}$ Even an often astute critic such as Bollinger supported continuation of the poll in the hope that the public might one day vote for state control of the liquor industry. ${ }^{96}$ In 1975 the Labour caucus threw out a proposal to abolish the referendum because some members wanted it retained to help further aims of community control of liquor. ${ }^{97}$ Whether a referendum was an appropriate mechanism to decide such a complex and potentially costly issue was of course questionable. To its credit the 1974 Royal Commission on the Sale of Liquor did consider the cost to government of buying the breweries, which it estimated at $\$ 400$ million. ${ }^{98}$ The commission tentatively recommended that the triennial poll be abolished, arguing that the government was unlikely to buy the breweries even if the public should ever vote for state control, and that prohibition had been a dead issue for 40 years. But with characteristic timidity it added the proviso that there should first be a referendum on whether or not the referendum should be abolished. ${ }^{92}$ A 1975 Justice Department report treated the commission's diffidence with undisguised contempt, describing its suggestion of a referendum on a referendum as 'hardly worthy of comment'. ${ }^{100}$

\footnotetext{
92 NZPD 1960 , volume 325 , p. 3259.

${ }^{3}$ Royal Commission on the Sale of Liquor, pp. 118, 146, 306.

24 New Zealand Herald, Toters turn out in force to dump licensing trusts', 21 November 2004, www.nzherald.conz/index.efm2ObjectlD =3612599, accessed 6 December 2004.

95 Report RCL, pp. 315-6.

96 Bollinger, 1967, pp. 87, 109-110, 191-3.

${ }^{97}$ Stace, p. 191.

9s Royal Commission on the Sale of liquor, p. 145. The figure is in 1974 dollars.

99 Royal Commission on the Salc of liquor, p. 146.

1000 Quoted by Stace, p. 191. The department argued forcefully but unsuccessfully for the immediate abolition of the poll.
} 
Not everyone accepted the government's use of referendums on liquor issues. The National Efficiency Board's 1917 recommendation for a special poll on prohibition was criticised by the weekly newspaper the New Zealand Free Lance. 'If a Parliament of duly elected representatives of the public has not the ability and courage to conduct its legitimate business...then why have a Parliament at all with its cumbrous and expensive machinery?"1"1 The Auckland Star editorialised in 1945 that liquor control is a subject upon which governments have for many years declined to take the responsibilities (and risks) of acting. They've passed it on to the people'. ${ }^{102}$ A few months later the paper criticised National's advocacy of liquor referendums. '[M]any people would prefer that Parliament should tackle the question directly, as it would any other question. ${ }^{103}$ There was much criticism of the government's decision to hold a referendum on hotel closing hours in 1967 instead of legislating change. Former Licensing Control Commission Chairman A.M. Goulding stated that 'approval will do no more than authorise the government to do something it has ample power to do without a referendum'. ${ }^{104}$ The president of the University of Otago Students Association noted that governments had made 'many momentous decisions' without referring them to the people. ${ }^{105}$ The Christchurch Presbytery sent a resolution to the Prime Minister asking why there was a referendum on six o'clock closing, but not on 'such a controversial issue as New Zealand's active involvement in the war in Vietnam'. ${ }^{106}$ Labour Minister Tom Shand agreed with the critics, stating that liquor questions were not suitable topics for referendums, which should be confined to constitutional issues. Liquor referendums were 'the price New Zealand political parties paid for the prohibition vote'. ${ }^{107}$ From the late 1960 s newspaper editorials regularly criticised the retention of the triennial licensing poll. ${ }^{108}$ The Justice Department was also a frequent critic, describing the poll in 1969 as 'an expensive farce.' declining. A survey after the 1975 general election found that over half of respondents -

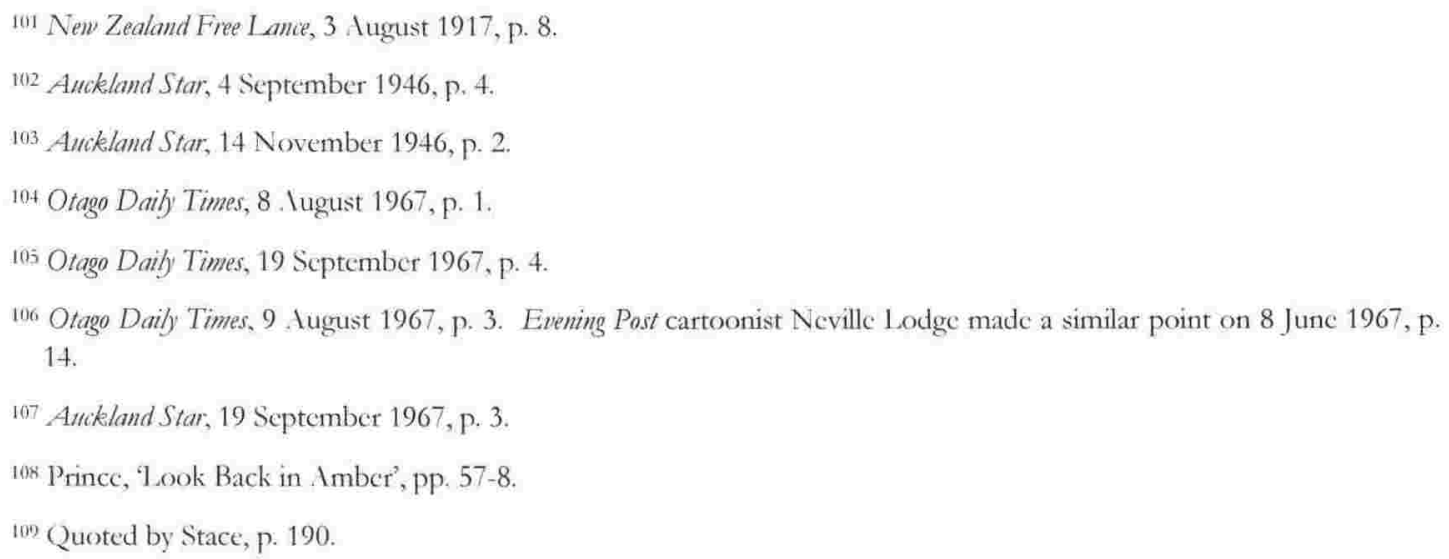


including the staunchly anti-continuance Methodists - thought the poll should end. ${ }^{110}$ Lack of public interest was further demonstrated by a survey after the 1978 general election in which a quarter of respondents seemed unaware that the referendum most of them had just participated in was about alcohol. Over 40 percent appeared to have no idea of the meaning of 'State Purchase and Control'."11

With this clear shift in public opinion the 1986 Working Party on Liquor was less timid than earlier inquiries on the subject of the triennial poll, questioning why this one issue should be made the subject of endlessly recurring referendums when other issues capable of having a major impact on New Zealand society are not submitted even once to the same process'. ${ }^{112}$ The working party was at a loss to explain the 'lack of political fortitude' that kept the poll going. ${ }^{113}$ Their report finally provided Parliament with the definitive recommendation its members clearly felt was required to justify abolishing the triennial poll. When the Sale of Liquor Bill was debated only one MP spoke in support of retaining the poll - Trevor Young, a former Alliance secretary. ${ }^{114}$ The majority of submissions on the bill came from the temperance lobby demanding the poll's retention, but MPs were clearly unconvinced by their arguments. ${ }^{115}$ With the enactment of the Bill the triennial poll ended, the last having been held in 1987.

However the abolition of the General Licensing Poll did not mean an end to liquor polls altogether, for pubs and bottle stores were still prohibited in much of suburban Wellington and Auckland due to no-licence. Despite the ending of local veto in 1918, for much of the twentieth century the number of no-licence districts continued to increase even though several electorates achieved the 60 percent majority required to restore licences. This was an unintended consequence of Seddon's 1893 Act that introduced local option. The Act made licensing districts contiguous with parliamentary general electorates, with the exception of the King Country which cut across several electorates. As a result, no-licence districts caused on-going problems for the representation

\footnotetext{
110 Stephen I evine and Nan Robinson, The New Zealand Voter: a survey of public opinion and electoral behaviour, Wellington, 1976, pp. 104-5. Levine and Robinson's survey showed that less than 40 percent of Methodists had voted Continuance in the 1975 poll but the majority still advocated its abolition.

111 l'rince, 'Look Back in Amber', pp. 66-69. Despite public uncertainty about its purpose, almost everyone who voted in general elections also voted in the General Licensing Poll, Prince, pp. 62-3.

112 Working Party on liquor, p. 23

113 Working l'arty on Liquor, p. 84.

114 N/PI 1989, volume 498, p. 10,969. For Young's Alliance credentials sec Manson, The IW ime is Red, p. 36.

115 Report of the Committee on the Sale of Liquor Bill, AJI IR 1987-1990, volume xviii, p. 63.
} 
commissions that regularly redrew electoral boundaries to deal with population changes, for their determinations could result in individual hotels or whole wet areas being transferred into dry districts. In the South Island this was caused by a shrinking number of electorates due to relative population decline, resulting in the absorption of some electorates by others. For example the township of Geraldine, which boasted six hotels, was added to the dry Ashburton electorate in 1907. Despite the fact that Geraldine voters had soundly rejected no-licence in 1905, all six hotels had to close when Ashburton reaffirmed its dry status in $1908 .^{116}$ A similar fate befell those parts of Otago that were incorporated into dry Oamaru. ${ }^{117}$ The efforts of publicans to avoid losing their licences because of boundary changes took up an inordinate amount of representation commission time. ${ }^{118}$

In the North Island the problems were caused by population growth which resulted in the representation commissions creating new no-licence electorates in Wellington and Auckland. The number of no-licence Auckland electorates doubled after new dry electorates were created in 1918 and $1928 .{ }^{119}$ The number of dry Wellington electorates also increased to four after an additional no-licence electorate was created there in $1928 .{ }^{120}$ Increasing numbers of voters therefore found themselves in electorates in which they had an option of voting for no-licence or restoration at each general election. But a mounting number of people also found themselves living in dry districts in which, like the residents of the King Country, they had no ability to vote for restoration of licences. This came about because of another anomaly in the licensing system that became apparent once local veto was abolished in 1918. From time to time the representation commissions eliminated dry districts altogether when redrawing boundaries. This did not mean that alcohol sales were thereby allowed in these areas; only that the residents no longer had the ability to vote to restore licences. For example the dry Ashburton electorate was eliminated in 1927. The town of Ashburton was then incorporated into the new MidCanterbury district with no licences and no way for the residents to vote to restore them,

\footnotetext{
116 Report RCI, p. 207.

117 Report RCI., p. 337.

118 Itkinson, Adventures in Democrayy, pp. 102, 136. The Representation Commissions were of course supposed to be trying to ensure equity of parliamentary representation rather than dealing with licensing issues.

119 Report RCI. p. 33.

${ }^{120}$ Report RCI, p. 33. Inother new no-licence electorate was created in Wellington in 1938 but one was abolished at the same time.
} 
while Geraldine was transferred into the Temuka electorate and likewise became a stranded dry town. ${ }^{121}$

Despite Ohinemuri voting wet in 1925 followed by Invercargill in 1943, and the elimination of the Bruce electorate in 1922 and Ashburton in 1927, there were still 11 dry districts in 1945. ${ }^{122}$ In addition there were a number of 'special' areas, such as Ashburton and the King Country, in which the residents had no ability to vote to allow liquor sales. In 1945 Parliament moved to prevent additional anomalies arising by amending the Electoral Act to freeze all no-licence districts at their existing boundaries. ${ }^{123}$ Over the next decade it then dealt with stranded dry areas on an ad hoc basis. In 1948 it legislated to allow one-off polls in Ashburton, Geraldine and the King Country. The first two went wet in 1949, while the King Country remained dry because the legislation allowed for a veto by Maori voters. ${ }^{124}$ In 1953 Parliament legislated for one-off polls in two more special areas - Porirua and Johnsonville - and provided for a second poll in the King Country with an equal weighting being applied to Maori and non-Maori votes. ${ }^{125}$ The 1953 Licensing Amendment Act (No. 2) also made provision for polls in other special areas if licences were applied for, but without specifying what these areas were. ${ }^{126}$ In 1954 Porirua, Johnsonville, the King Country, Clutha and Mataura all voted to restore licences, followed by Oamaru in $1960 .{ }^{127}$ No-licence became a suburban phenomenon confined to four districts in Auckland and three in Wellington. ${ }^{128}$ In addition the northern Wellington suburbs of Wadestown, Ngaio, Khandallah and Tawa remained as dry special areas. ${ }^{129}$ The voters in these districts were in no hurry to restore licences, and by the time the Working Party on Liquor produced its report in 1986 there were still four suburban nolicence districts and four special areas. ${ }^{130}$ In 1989 Parliament abolished the remaining

\footnotetext{
121 Report RCJ, p. 207. Ironically Ishburton had the highest restoration vote, apart from Ohinemuri, in both 1922 and 1925, report RCL., pp. 209-210.

122 Report RC.., pp. 209-210.

123 Tilectoral Imendment . Ict, Nen Zealand Statutes 1945, p. 59.

${ }^{12+}$ Licensing Amendment Act, New Zealand Statutes 1948, volume II, pp. 975-983, and NKOYB 1950, p. 893.

${ }_{125}$ Licensing Imendment Act (No. 2), New Zealand Statutes 1953, volume II, pp. 943-953.

126 Licensing Amendment Act (No. 2) 1953.

127. IJHR 1955 and 1961, H-33B.

128 'The dry licensing districts were Auckland Suburbs, Fiden, Grey I.ynn, Roskill, Wellington South, Wellington Fast and Wellington West.

129 Working Party on Liquor, p. 89. These areas, along with Johnsonville and Porirua, had been part of the former Wellington Suburbs clectorate that went dry in 1908.

${ }_{130}$ Working Party on Liquor, pp. 85, 89 .
} 
special areas except Tawa, which it effectively turned into a fifth no-licence district. ${ }^{131}$ Then in 1990, under cover of controversial electoral reform legislation, Parliament moved to reduce the share of the vote required for restoration from three-fifths to a bare majority. ${ }^{132}$ Such a change had been regularly advocated since the $1920 \mathrm{~s}^{133}$ The amendment had the effect that was presumably intended. The last remaining dry districts voted to restore licences during the 1990 s, with Eden, Roskill and Tawa finally going wet in $1999 .{ }^{134}$

\section{Figure 3.2: Numbers Voting for Prohibition in General Licensing Polls 1919-1972}

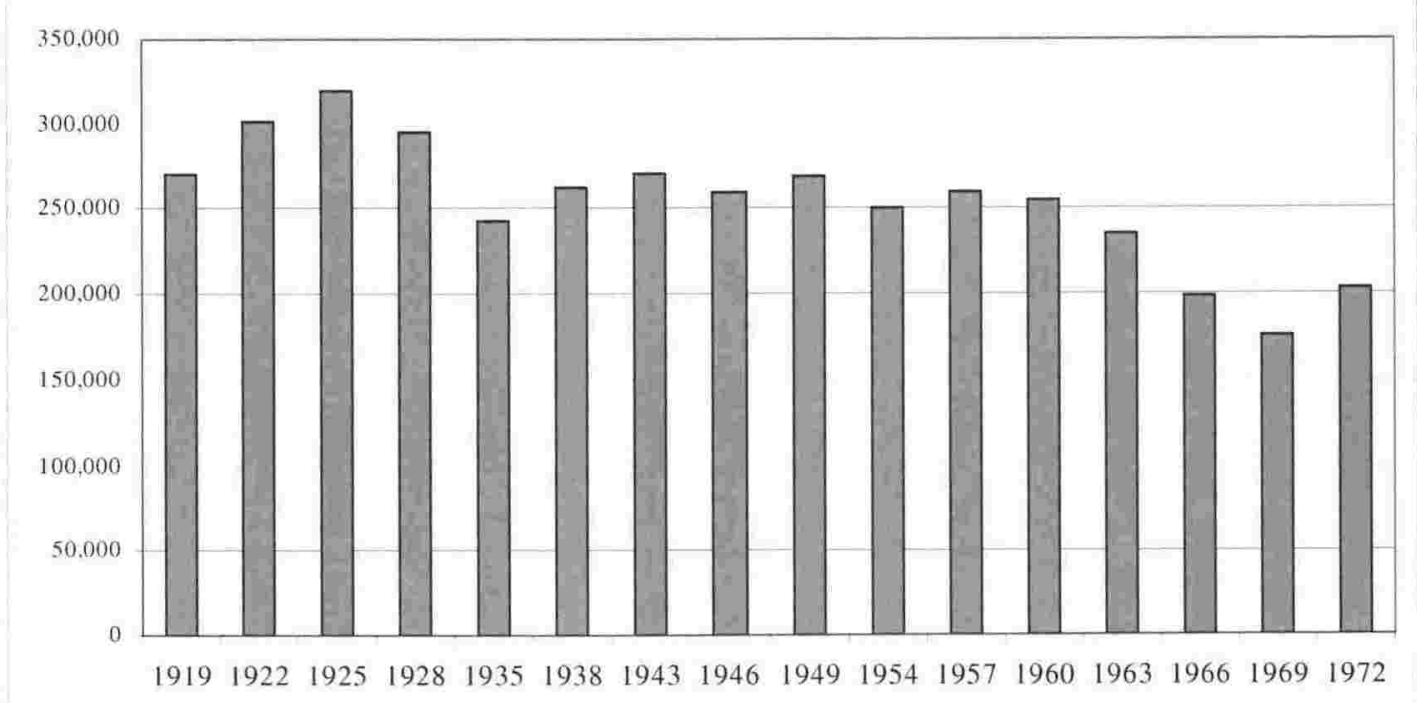

Source: NZOYB, various years 1920-1974.

\section{The Poll and Prohibition Support}

Whatever their usefulness in other respects, the numerous liquor polls in New Zealand provide a valuable source of data for historians. The votes held under the General Licensing Poll from 1911, along with the earlier votes on local option, provide a useful barometer of the progress of the prohibition movement during the twentieth century. In

\footnotetext{
131 Sale of Liquor. Act, New Zealand Statutes 1989, volume 2, pp. 1358-9. Tawa was still called a 'special area' but provision was made for restoration polls every three years as in no-licence districts.

132 J ocal Restoration Polls Ict, New Zealand Statutes 1990, pp. 74-87. 'I his Ict repealed the Jicensing Amendment Act 1910 that laid out the rules for local restoration polls.

133 A parliamentary select committee recommended such as change in 1921, Report of the Parliamentary Iicensing Committce, AJHR 1922, I-14.

134 NZOYB 2002, p. 39.
} 
the early years of the century support was on the rise. Much to the consternation of the liquor industry the number of dry electorates doubled from six to twelve following the 1908 local option poll. The Brewers' Association held a special general meeting in 1909 to discuss the rise in the no-licence vote and the apparent lack of support in parliament for the industry. Members favoured asking the government to abolish barmaids, whose presence in bars was seen as encouraging no-licence voting amongst jealous wives who resented their husbands spending their evenings in female company. ${ }^{135}$ An end to late closing permits was also suggested, thereby making ten o'clock closing universal. Although the government introduced both these measures the following year, national prohibition received 56 percent support in 1911. ${ }^{136}$ These pre-war years were perhaps the zenith of the prohibition movement in New Zealand. The prohibition vote fell in 1914 but picked up again under the revised rules for the Special Licensing Poll and the General Licensing Poll held in 1919. Prohibition received 49 percent of the vote in the April 1919 ballot. ${ }^{137}$ The December poll was even closer. With over half a million votes cast, New Zealand came just 1632 votes short of following Finland, Norway, Iceland, the United States and most Canadian provinces in banning some or all of the liquor traffic. ${ }^{138}$

From December 1919 an identical question was asked of the electorate every three years which provides a good measure of trends in support for prohibition over some 70 years. The polls of 1919, 1922 and 1925 saw a huge battle between prohibitionists and the liquor industry for the hearts and minds of the public. Prohibitionists placed a total of 56 advertisements in the Dominion newspaper in the weeks before election day in the three campaigns. Anti-prohibitionists placed 66 advertisements in the Dominion over the same three periods, 20 of which were for state control. ${ }^{139}$ In the early 1920 s the Alliance increasingly centralised its organisation and employed more staff. In 1925 it distributed

\footnotetext{
${ }^{135}$ Minutes of the Special General Mecting of the Brewers' Association, 23 March 1909, in Brewers' and Wine and Spirit Merchants' Association of New ' Lealand: Records, MS-1'apers-1621-01, Alexander Tumbull library.

136 Cocker and Murray, pp. 271-2.

137 This was the famous poll in which some 40,000 troops on ships or in army camps in New Zealand and overseas cast special votes that swung the result, NZ Gazette 1919, volume 2, p. 1949. Special votes played almost no part in the second poll in 1919 in which the result was closer, NZ Gazette 1920, volume 1, p. 762.

138 Figures calculated from Nen Zealand Gazette, 1920, volume 1, p. 672. It is argued here that for prohibition to carry would have required 50 percent plus one $(271,882)$ of the 543,762 votes cast. National Prohibition received 270,250 votes, just 1632 short of the target. Other writers have used a different methodology and have therefore come up with different figures. In Norway only the sales of spirits and fortified wines were banned, Sturla Nordlund, Norway' in Blocker et al, Aliobol and Temperance in Modern History: an International Encyclopedia, pp. 459-60.

139 The Domimion, all issues 2-17 December 1919, 1 November to 7 December 1922 and 2 to 31 October 1925. Some of the prohibition advertisements were placed by the Salvation Army. The state control advertisements were placed by the Moderate League and the Anglican Church.
} 
three issues of a free campaign newspaper titled Good Luk in addition to its fortnightly publication Vanguard, and increased its newspaper advertising over previous years. ${ }^{140}$ The 1925 licensing poll campaign cost the Alliance over $f 50,000 .{ }^{141}$ Although the liquor industry spent twice this amount the Alliance had substantial voluntary resources to draw on; for example churches made billboards available for campaign posters and preached prohibition from the pulpit. ${ }^{142}$ The 1925 publication of The New Zealand Alliance Handbook provided potential prohibition advocates with an impressive compendium of information to draw upon during the licensing poll campaign. ${ }^{143}$

\section{Figure 3.3: Percent Voting for Prohibition in General Licensing Polls, 1919-1987}

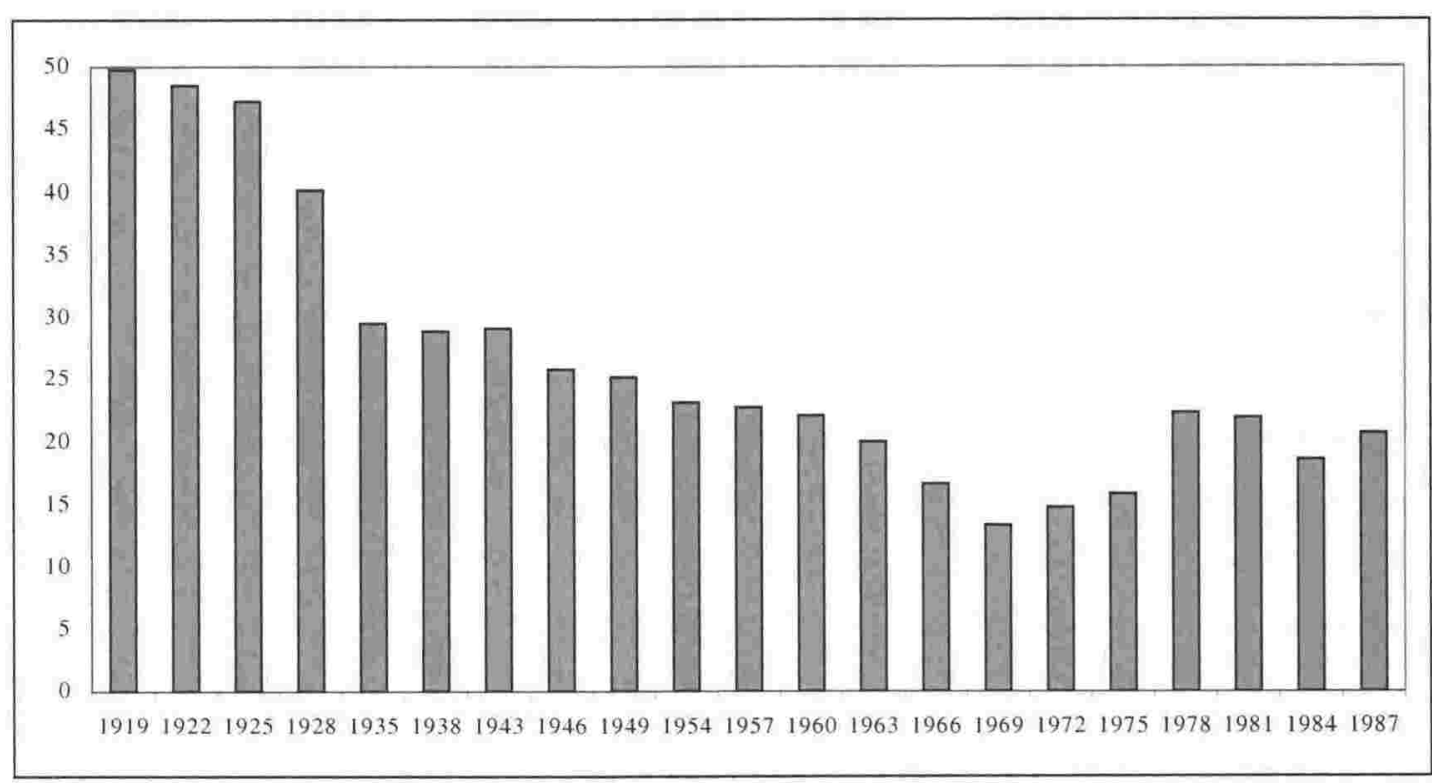

Source: NZOYB various years 1920 to 1990.

As can be seen from Figure 3.3, prohibition support fell slightly in 1922 and 1925 despite the Alliance efforts, for the liquor industry also increased its campaigning. Ironically with the introduction of prohibition in several countries, most notably the United States, the industry was able to go on the offensive. For decades prohibitionist propaganda had been able to draw on international evidence of the evils of drinking, but during the 1920 s the industry was able to draw on an increasing array of evidence on the detrimental effects of prohibition. In 1922 the National Council published seven issues of a free monthly newspaper with the cheesy title Cheerio, which also came out in a limited form in 1925 and

\footnotetext{
140 Cocker and Murray, p. 135-8. No issues of Good Lak seem to have survived.

$1+1$ PRCL, p. 7086.

142 PRCL, p. 7086 and Cocker and Murray, p. 130.

${ }^{143}$ J. Malton Murray, The New Zealand Alliance Handbook: a Handy Guide for Speakers and Writers, Wellington, 1925.
} 
1928. ${ }^{144}$ Cheerio's self-proclaimed purpose was to combat 'the dismal band of selfappointed reformers who would eliminate all joy from the world'. ${ }^{35}$ The newspaper highlighted the alleged failures of prohibition in the United States, especially enforcement difficulties and rising crime, and claimed that civil liberties there were being progressively curtailed. The paper drew light-hearted attention to attempts in various parts of America to ban smoking and beauty contests and to enforce modest skirt length, church attendance, and codes of seaside dress. ${ }^{146}$ It was claimed that dancing, horse racing and the theatre would be the next targets. ${ }^{147}$ Sir Arthur Conan Doyle was quoted as saying on an American visit that 'a man kissing his wife in the street is in danger of violating some amendment or other. ${ }^{148}$ Cheerio was not alone in mocking prohibition. Visiting American prohibitionist Mary Harris Armor wrote in 1922 that '[n]ot a cartoon or jest flung at prohibition was ever printed in America, that was not duplicated in New Zealand'. ${ }^{149}$

Most of Cheerio's advertisements were aimed at women, attempting to arouse fears that under prohibition their homes would be invaded by government agents looking for liquor, the price of household essentials would increase because of lost tax revenue, and their husbands would become less manly. ${ }^{150}$ No sane woman wants a finicky milksop for a husband,' declared one advertisement. 'Every woman who votes prohibition casts a slur upon the manhood of this country. ${ }^{151}$ Drawing on an Alliance tradition, Cheerio featured essay writing and slogan competitions, including a ten guinea prize for the best essay on 'why I am opposed to prohibition'. ${ }^{152}$ The paper also included serious editorial content such as a syndicated column by H. L. Mencken and an article by Canadian economist Stephen Leacock. ${ }^{153}$

\footnotetext{
1+4 Two issues of Cheerio with a cover price of 1d were put out in 1925 and again in 1928. They lacked the humour of the 1922 issues. The newspaper's publication was of course timed to coincide with the triennial polls.

$1+5$ Cheerio, June 1922 , p. 1.

146 Cheerio, September 1922 , p. 3.

147. Cheerio, November 1922, p. 2.

1ts Cheerio, October 1922, p. 12.

(4) (Quoted in Tyrrell, Woman's World, Woman's Empire, p. 278.

${ }^{150}$ Cheerio, September 1922, p. 2, December 1922, p. 2, September 1925, p. 10.

151 Cheerio, Scptember 1922, p. 2.

152 Cheerio, August 1922, p. 2.

153 Cheerio, August 1922 , p. 5 .
} 
The liquor industry's newspaper advertising in 1922 made fewer claims than Cheerio about the negative effects of prohibition in North America. It more commonly argued that increased taxes would be needed to replace lost liquor revenue and fund the enforcement of prohibition, a sensitive issue at a time when taxes were already increasing. ${ }^{154}$ The Alliance rebutted the taxation claims and argued that prohibition in America had been a positive thing. ${ }^{155}$ In 1925 liquor industry advertisements made significantly more claims about the American situation and made greater use of the 'open letter'. These advertisements had been used to a limited extent in 1919 and 1922 and generally featured a letter from a prominent American citizen, such as a Congressman, making allegations about the unenforceability and other negative effects of prohibition. ${ }^{156}$

The 1922 and 1925 campaigns were largely a draw between prohibition and continuance, with state control being the big loser despite the resources devoted by its supporters to the 1922 campaign. But the efforts of the Alliance had considerably drained its financial resources, which by the late 1920 s had to support a substantial permanent workforce. At its 1928 annual meeting the Alliance decided to halve its 1928 campaign expenditure by forgoing newspaper advertising and commercial hoardings. ${ }^{157}$ Instead it relied on church property billboards and mass meetings featuring visiting overseas speakers and Methodist and Presbyterian Ministers. ${ }^{158}$ This left the newspaper advertising field open to the liquor industry, which made full use of it despite cutting back by over 20 percent on its own campaign expenditure. ${ }^{159}$ The National Council's advertisements in the Dominion highlighted the fact that Norway and most Canadian provinces had already overthrown their prohibition laws and claimed a rising tide of evidence from the United States on the negative effects of prohibition there. ${ }^{161}$ An open letter from a US senator implored New Zealand voters to 'keep out such lawlessness and corruption' and other open letters

\footnotetext{
1.5 'The Dominion, 1 November 1922, p. 5, 8 November, p. 5, 23 November, p. 12, 28 November, p. 4, 2 December, p. 3.

155 The Dominion, 13 November 1922, p. 4, 24 November, p. 11, 29 November, p. 5, 1 December, p. 11, 6 December, p. 4.

156 The Dominion, 3 October 1925 , p. 16, 17 October, p. 22, 20 October, p. 13, 22 October, p. 14, 24 October, p. 22,27 October, p. 7, 29 October, p. 7. The Moderate League also used this technique, The Dominion, 30 October 1922, p. 3.

157 Cocker and Murray, p. 139 and PRCI, p. 7086.

158 Cocker and Murray, p. 139. Iccording to Cocker and Murray over 300 churches offered the use of their property for the prohibition campaign.

${ }^{159}$ PRCI., p. 7086.

160 See, for example, Dominion, 8 November 1928, p. 9, 9 November, p. 27, 10 November, p. 31. As noted earlier, Norway had in fact only prohibited spirits and fortified wines.
} 
expressed similar sentiments. ${ }^{161}$ It did not help the Alliance cause that midway through the campaign the Dominion published an article by long-serving Hutt MP Thomas Wilford titled 'Why Canada abandoned Prohibition'. Wilford had visited Canada on a field trip and wrote at length on the enforcement problems and alleged intemperance that had dogged the authorities. ${ }^{162}$ The only bright spot for the Alliance was the election of Herbert Hoover as US President a week before the New Zealand licensing poll. Hoover was seen as more sympathetic to prohibition than his opponent $\mathrm{Al}$ Smith and his election was therefore interpreted by the Alliance as an endorsement of prohibition in America. ${ }^{163}$ Despite this reprieve the prohibition vote fell to 40 percent in the 1928 poll, its lowest level yet.

Perhaps because of its limited 1928 campaign the Alliance's finances appeared to be in a relatively healthy shape the following year. ${ }^{164}$ When the organisation published Temperance and Probibition in New Zealand in 1930, the authors expressed confidence that prohibition could recover its support as it had done after a similar reversal in 1914. ${ }^{165}$ But the Alliance was hit badly when the expense of publishing the book was followed by the onset of the depression. ${ }^{166}$ Its accounts for early 1929 showed an income of $£^{22,559}$ and net assets of $£ 16,926 .{ }^{167}$ By 31 March 1931 the annual accounts showed an income of just $£^{1270}$, a big reduction in staff numbers, and net assets of just $£ 4914$ due to the sale of vehicles and depletion of the capital account. ${ }^{168}$ The Alliance's fortnightly publication Vanguard came to a halt after nearly 25 years, to be relaunched in 1932 as a quarterly. ${ }^{169}$ The organisation no doubt gratefully agreed to the liquor industry's suggestion that the scheduled 1931 liquor polls be cancelled. ${ }^{170}$ Its 1932 annual report lamented 'one of the most difficult

\footnotetext{
161 The Dominion, 3 November 1928, p. 31, 5 November, p. 17,6 November, p. 18.

162 Thomas Wilford, 'Why Canada abandoned Prohibition', The Dominion, 9 November 1928, p. 13.

163 The Dominion, 13 November 1928, p. 20. The issues in the American campaign were somewhat more complex than portrayed by the Alliance, Hugh Brogan, Longman History of the United States of America, London, 1985 , p. 520.

16+ New Kcaland Alliance Annual Accounts for the 10 months ending 31 January 1929 in New Zealand Alliance: Records, 77-206-14/9, Nexander lumbull J ibrary.

165 Cocker and Murray, pp. 140-3.

160 Bollinger, 1967 , p. 83.

167 New Zealand Mlliance Annual Accounts for the 10 months ending 31 January 1929 in New Zealand Alliance: Records, 77-206-14/9, Alexander Tumbull library. As the accounts are for 10 months only it is unclear whether the income represents a full year, which would depend on the timing of subscription collection.

16, New Zealand Mlliance Annual Iccounts for the year ending 31 March 1931 in New Zealand Nlliance: Records, 77206-14/09, Alexander Turnbull Library.

169 T anguard, March 1932, New Series no. 1.

170 Bollinger, 1967 , p. 83 .
} 
years' in the history of the movement, for '[i]n common with churches [and other organisations] dependent upon voluntary contributions for financial support, the New Zealand Alliance has felt the full weight of the economic depression'. ${ }^{171}$

Yet the fall in Alliance membership and donations cannot entirely be put down to the economic downturn. Although an economic recovery was underway by 1934, the Alliance accounts were in no better shape than they had been in $1931 .^{172}$ Despite better times the organisation was unable to attract back former members with their regular donations. The Alliance spent just $f_{,} 1730$ on its 1935 prohibition campaign compared with some $f 79,000$ spent by the National Council. ${ }^{173}$ Prohibition support fell to under 30 percent, a decline of nearly 40 percent in ten years. The reasons for both the loss of support for prohibition and the slump in Alliance membership can be found largely in overseas events. By 1935 almost every country and territory that had introduced prohibition had overturned it. Finnish voters threw out prohibition in a December 1931 referendum and Iceland followed suit some two years later. ${ }^{174}$ By 1935 tiny Prince Edward Island was one of the few remaining prohibition territories of any significance in the industrialised world. ${ }^{175}$ But of course it was the ending of prohibition in the United States in 1934 that gained the most attention. ${ }^{176}$ In a country where voters were regularly asked to take decisions relating to alcohol, the New Zealand public cannot have helped but be aware of the failure of 'the American experiment', which the liquor industry exploited to the full. 'The Prohibition Experiment has been heavily paid for by other countries, all of which have repealed this impossible law', declared a typical National Council advertisement. ${ }^{177}$ Other slogans declared 'you know what prohibition did to America', 'remember - all the world has rejected prohibition', and called prohibition 'an acknowledged universal failure'. ${ }^{178}$ It was claimed that prohibition had 'thoroughly

\footnotetext{
171 New Zealand Illiance Innual Report for the year ended 31 March 1932, New Zealand Illiance Innual Meeting Minutes 1932-1954, New Zealand Alliance: Records, 77-206-14/07, Alexander Turnbull Library.

172 New 7ealand Illiance Innual Iccounts for the year ending 31 Narch 1934 in New 7ealand Mlliance: Records, $77-$ 206-14/09, Alexander Turnbull Library.

173 PRCL, P. 7086

${ }_{17+}$ Butler and Ranney, Referendums, pp. 267-8.

175 Heron, Booze, pp. $269-70$.

176 In fact beer sales had been legalized in the United States nine months before the ending of constitutional prohibition, Blocker, p. 128.

177 ' The Dominion, 18 November 1935, p. 15.

178 The Daminion, 22 November 1935, p. 22 and 23 November, p. 18 and 25 November, p. 17.
} 
demonstrated its calamitous results both economically and morally. ${ }^{179}$ Edith Thornton, writing in 1936, noted that the Alliance had held up American prohibition as an example to voters and 'the most telling blow to prohibition in New Zealand was dealt when the U.S.A. went "wet". ${ }^{181}$

Social changes were also a factor in the decline in support for prohibition. An apparent decline in the influence of moral evangelism can be seen from changes in newspaper advertising. During the 1920 s and 1930 s advertisements increasingly featured women in alluring poses, often marketing a product for which the picture bore little relevance. Advertisements for alcohol, cigarettes and gambling, which were rare in 1919, were commonplace by the $1930 \mathrm{~s} .{ }^{181}$ Thornton also blamed the cinema for the decline in prohibition support after 1925 . 'The modern films have probably helped create a tolerance for drinking since it is a feature of so many films and the results are seldom unpleasant. $^{\text {,182 }}$ She also considered that the cinema gave people something to do in the evening, for in earlier times a prohibition rally could be an exciting evening out, particularly if opponents turned out to heckle. 'Before the advent of the picture theatre it was possible to have enormous crowds at prohibition meetings and lectures. ${ }^{183}$ In 1908 fire hoses had been used to prevent 1000 people forcing their way into a crowded Dunedin hall to witness a debate between a wowser and a drinker. The debate was eventually abandoned because no one could be heard. ${ }^{184}$ Such scenes seemed unlikely by the 1930s.

The onset of the great depression during the prohibition era probably helped discredit the idea that banning alcohol led to economic efficiency. The argument does not appear to have been raised in submissions to the 1945 Royal Commission on Licensing, despite some of the hearings coinciding with the war when economic efficiency might be seen as

\footnotetext{
179 The Dominion, 23 November 1935, p. 18.

180 Fidith Thornton, ' 1 History of the Prohibition Movement in New Zealand,' M. 1 thesis in History, Canterbury University College, 1936, p. 59.

181 'l'hese observations are based on impressions gained from surveying the Dominion and Auckland Star newspapers of the period for prohibition poll advertisements.

182 Thornton, 'A I listory of the Prohibition Movement', p. 74.

183 Thornton, pp. 74-5. Other researchers have also noted boredom as a motive for joining the prohibition movement sec Turncy, "The New Kcaland Alliance in Auckland', p. 30.

184 Phillips, A Man's Countoy, p. 55.
} 
being of concern. ${ }^{185}$ The prolonged period of hardship that many New Zealanders went through during the depression probably reduced the credibility of the notion that alcohol was the root cause of most social problems, as it did in the United States. ${ }^{186}$ The Alliance had long clung to the belief that drink was the cause of most of society's ills. Such a doctrine may have found adherents in New World societies replete with resources and opportunities, but only so long as the good times lasted. The depression of the 1930 s hit drinkers and non-drinkers alike, possibly causing many New Zealanders to modify their views as to the link between alcohol and poverty.

By the 1940 s prohibition seemed a fading dream to many of its advocates. The movement received further setbacks in the nation's dry districts. The vote for restoration of licences in dry areas generally increased with each poll after 1908, particularly in the non-suburban districts, all of which went wet again between 1925 and $1960 .{ }^{187}$ An Alliance stalwart, Rugby Pratt, admitted to the 1945 Royal Commission that the organisation was putting its faith in education to revive prohibitionist sentiment in later generations. ${ }^{188}$ With the slump in support the value of continuing to fight the liquor traffic was questioned in some traditionally prohibitionist circles. At a 1948 meeting of the General Assembly of the Presbyterian Church, some criticised the Alliance's continued commitment to prohibition. ${ }^{18}$ ) Although it continued to campaign for prohibition through its official organ Outlook, the church was beginning to waver in its commitment to total abstinence. ${ }^{190}$ By 1960 the church had acknowledged a split in opinion between members advocating moderation and those advocating total abstinence and abandoned its official commitment to prohibition. ${ }^{191}$ As more than one in five New Zealanders were professed Presbyterians at the time, this change was significant. ${ }^{192}$ Once it had abandoned a prescriptive stance that identified temperance with abstinence, the church was forced to rethink what temperance actually meant and what its new stance on

\footnotetext{
183 However the government did legislate to elose the pubs on Saturday afternoons and to reduce the alcohol content of beer during the war, Report RCl., pp. 68-9.

186 Blocker, American Temperance Movements, p. 125.

${ }_{187}$ Report RCL, pp. 209-10 and AJHR H-33B, 1947, 1955 and 1961 .

188 PRCL, p. 5213.

189 'The Dominion, 11 November 1948, p. 6.

190 Fraser Paterson, 'In Historical Inalysis of Issues Within the Presbyterian Church of New Zealand 1945-1985', Master of Theology thesis, University of Otago, 1985, pp. 20-22.

191 Paterson, 'Issues Within the Presbyterian Church', pp. 27-32.

192 In the 1961 and 1966 censuses some 22 percent of respondents classified themselves as Presbyterians, N7OYB 1964, p. 86 and 1979 , p. 78 .
} 
liquor should be. This led many within the church to start questioning its traditional opposition to innovations such as licensed restaurants and the evening opening of bars. ${ }^{193}$

In 1965 the Alliance reaffirmed that its aim was 'to secure the ultimate abolition of the liquor traffic in New Zealand by the direct vote of the people.' ${ }^{194}$ By then it was becoming increasingly out of step with its traditional church allies, who seemed less impervious to social change. The issue of six o'clock closing led to a fatal schism within the movement, for it had become apparent to many temperance advocates that the six o'clock swill did little to encourage temperate drinking. ${ }^{195}$ In the 1960 s the prohibition vote began to fall in absolute as well as relative terms, and reached its nadir in 1969 when even state control voters outnumbered prohibitionists, as shown by Figure 3.4 below. Pethaps signalling a new approach, in 1972 the Alliance changed its official name to the New Zealand Temperance Alliance. ${ }^{196}$ Then suddenly in 1978 the organisation was given a new lease of life. In the triennial licensing poll of that year the prohibition vote leapt to record levels in numerical terms. In terms of percentage of the vote captured, prohibition returned to its levels of the 1950 s while continuance support reverted to its 1935 level. ${ }^{197}$ This sudden success revitalised prohibition and temperance groups. The Alliance, under new leadership, launched an old-style temperance pledge campaign advocating 'an alcohol free way of life. ${ }^{198}$ It also enlisted the support of a number of mayors in its campaign to close bars for an hour every evening for a 'dinner break' ${ }^{199}$ A parliamentary select committee was sympathetic to the idea. ${ }^{200}$ Journalists suddenly took notice of the Alliance, and its General Secretary Tom Quayle received national headlines when National's Deputy Chief Whip objected to him criticising MPs' alleged drinking habits. ${ }^{201}$

\footnotetext{
193 Paterson, 'Issues Within the Presbyterian Church', pp. 32-7.

194 Vanguard, May 1965, p. 1.

195 This point is discussed in more detail in Chapter 5 .

196 Manson, When the Wine is Red, p. 123.

${ }^{197}$ Figures calculated from Bloomfield, Handbook of Historical Statistics, p. 376, and NZOYB 1990, p. 70.

198 John McKay (director), Fight the Good Fight, Reel Images Film Production/'l'elevision New Zealand, New Zealand Film Archive Reference Number; Film: F18007. The Archive dates this television documentary as 1985, but as the material in it clearly relates to 1979 a more plausible date is 1980.

199 McKay, Fight the Good Fight.

${ }^{200}$ Report of the Select Committec on Violent Offending, AJHR 1979, I-18.

201 McKay, Fight the Good Fight.
} 
Figure 3.4: Numbers Voting Prohibition and State Control, 1960-1987

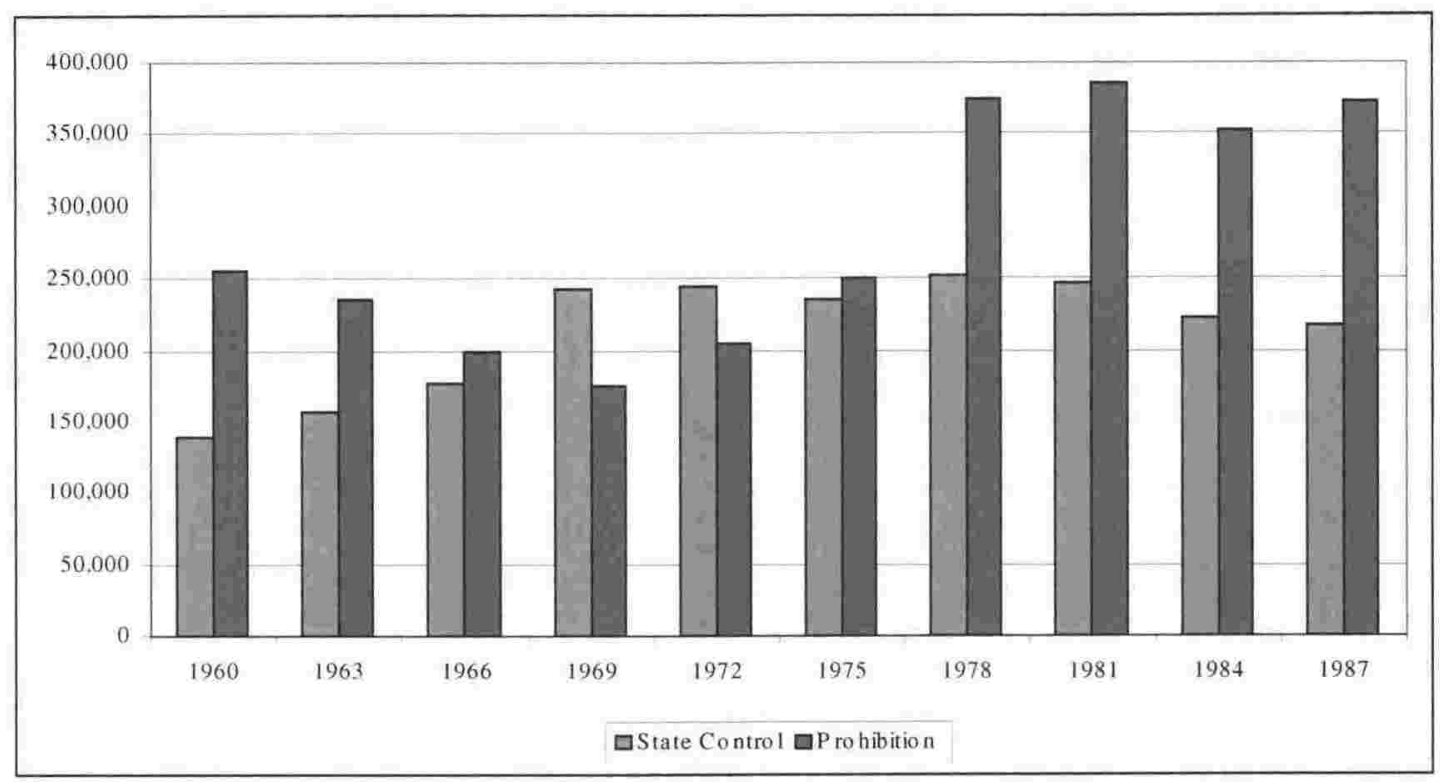

Source: NZOYB 1962-1990.

The desire to ban liquor sales probably had little to do with the surge in prohibition voting in 1978. That year feminist groups campaigned for people to use the moribund triennial poll as a referendum on the abortion laws, which they alleged were too strict. They therefore encouraged supporters to vote prohibition to signal support for repeal of the Abortion, Contraception and Sterilisation Act 1977. ${ }^{2112}$ This may have started a $1980 \mathrm{~s}$ trend of using the redundant poll as a protest vote over such issues as nuclear warship visits, the 1981 Springbok tour, and economic restructuring. ${ }^{213}$ It is notable that third party voting, traditionally seen as a protest option, also rose considerably in the three polls after 1975, although it slumped in $1987 .^{204}$ Richard Newman speculated that a similar protest vote phenomenon was behind the extraordinarily high prohibition vote in the first national prohibition poll in 1911. He argued that many voters were disillusioned after over 20 years of Liberal government but were also uninspired by the opposition alternatives. The reaction by many conservative voters was to use the General Licensing Poll as a form of protest vote. ${ }^{215}$

\footnotetext{
202 A more detailed account is provided by Stephen Jevine, The New Zealand Political System: Politics in a Small Society, Sydncy, 1979, p. 103. Sce also 'Why that Liquor Poll Continucs', Dominion, 27 November 1981.

203 A word-of-mouth campaign in 1981 encouraged prohibition voting to show disapproval of the South African rugby tour carlicr in the ycar.

204.4 tkinson, Adventures in Democracy, pp. 249-50.

205 Newman, New Zealand's vote for Prohibition in 1911', pp. 64-66.
} 
In 1984 the proportion of voters supporting Continuance recovered to an all-time high of 70 percent and the brief surge in prohibition support was quickly forgotten. ${ }^{216}$ In 1989 the government abolished the General Licensing Poll with barely a murmur of protest. Quayle retired as Alliance General Secretary the following year and the organisation faded into oblivion shortly afterwards. ${ }^{217}$ Somewhat tellingly, when a political party calling itself the Alliance was formed in 1991, no one associated it with prohibition. Thirty years earlier that would have been unthinkable. However the WCTU survived into the twentyfirst century. ${ }^{208}$

\section{The Consequences of the Poll}

While prohibition was effectively a dead issue by the 1930 s, the effect of regular national polls on the issue continued to resonate over subsequent decades. There is evidence these regular polls helped maintain support for prohibition at a higher level than it might otherwise have done so. The 1931 licensing polls were cancelled as a cost-cutting measure and the 1934 election was delayed for a year, meaning 'seven years without the prohibitionist propaganda for which the triennial licensing poll provided an excuse. ${ }^{209}$ This hiatus in prohibition campaigning possibly contributed to prohibition attracting fewer voters in 1935 than in any poll until 1963. The next worst showing was in 1954, as no licensing poll was held with the 1951 snap election, meaning five years between polls. However a two-year delay of the general election scheduled for 1941 did not harm the prohibition vote, probably because of enhanced support for prohibition in an atmosphere of wartime austerity.

More importantly, regular polls helped ensure that restrictions on alcohol were retained once they were imposed. By instilling in voters and politicians alike the idea that referendums and liquor went hand in hand they made politicians wary of initiating reform. Polls inhibited government action on liquor issues by providing politicians with a regular reminder of the strength of the prohibition lobby. The General Licensing Poll was basically a conservative instrument. It enabled voters to choose between retaining the status quo, banning alcohol altogether, and socializing the industry. There were no

\footnotetext{
206 NZOYB 1990, p. 70.

207 P'crsonal communication from Tom Quayle, 8 December 2004

208 Personal communication from Tom Quayle.

${ }^{209}$ Bollinger, 1967, p. 84.
} 
options for those who wanted controls to be less restrictive as there had been to a limited extent between 1881 and 1893. As has been seen, support for prohibition was almost consistently over 250,000 votes until 1966 . Few politicians would choose to upset a quarter of a million voters when no-one is clamouring for change. In the 1920s, when prohibition still attracted considerable support in both numerical and percentage terms, parliament was paralysed to act on liquor issues and threw out Bills proposing minor reforms to the licensing laws in almost every year of that decade. ${ }^{210}$ In the 1930 s the only measures passed by parliament were a further tightening of restrictions. ${ }^{211}$ 'One must not mention [alcohol] or one might lose votes, an anti-wowser MP told parliament in $1944 .{ }^{212}$

The impression that politicians were afraid of the strength of the prohibition lobby persisted after the Second World War. In 1955, in response to a Licensing Control Commission request for its views on pub closing hours, the Dunedin Licensing Committee replied that expressing any opinion was a waste of time. No Government is in the slightest degree likely to flout the wishes of the Temperance element without putting the issue to the country, ${ }^{213}$ That same month an Alliance official reminded politicians of the danger of ignoring the continuing strength of the prohibition lobby, pointing out that over 400,000 voters had supported either prohibition or state control in the 1954 triennial poll. ${ }^{214}$ In 1959 the Gry River Argus criticised successive governments' reliance on liquor referendums because of the difficulty in formulating questions that satisfactorily encompassed a variety of views.

It is therefore apparent that changes to our drinking laws must come from executive decisions rather than appeals to the country. Considerable courage is needed by the Government making such decisions. The liquor laws have traditionally been a political hot potato. In the later years of the nineteenth century, the wrath of the temperance advocates could alone fell governments, and the respect which their strength inculcated has persisted in official circles to this day. We believe there is a tendency today to

\footnotetext{
${ }^{210}$ K Malthus, "The Liquor Problem in New Zealand', M. A thesis in I listory, University of Canterbury, 1948, p. 59.

211 I'or example a 1933 . Ict prevented advertising liquor in no-licence areas, Malthus, "1he I iquor Problem', p. 59.

212 N7.PD 1944, volume 264, p. 72.

213 Letter dated 2 September 1955 in Licensing Control Commission file, 'Suggested Changes in licensing Hours', Archives New Zealand IMDM, 567, 13e, 4/1/26.

214 Te Amamutu Courier, 12 September 1955. 'The official argued that both prohibition and state control voters were showing discontent with the status quo.
} 
exaggerate the influence of the temperance group. But a government must still feel extremely secure or unusually courageous to take action likely to offend them. ${ }^{215}$

Bollinger argued that the triennial licensing poll was to blame for the apparent ongoing fear within parliament of the temperance lobby. 'In many electorates, and not just marginal ones, the Prohibition vote is a great deal bigger than the difference between the votes for the successful candidate and his closest rival. Some of our politicians interpret this as meaning that if something was done to offend prohibitionist susceptibilities the fate of a Government might be sealed. Accordingly prohibitionist sentiment is treated by the most hard-bitten politicians with much more respect than the size of its following would seem to justify. ${ }^{216}$ The way the triennial poll continued to help maintain the influence of the temperance movement was illustrated by the effects of the significant increase in prohibition voting in $1978 .^{217}$ As noted earlier, this apparent increase in support encouraged the Alliance to launch a campaign to close bars for a meal break every evening and a parliamentary select committee on violent offending consequently recommended an experiment along these lines. ${ }^{218}$ The fact that successive governments were nervous of abolishing the triennial poll until 1989 also demonstrated the ongoing fear that politicians had of upsetting the temperance lobby. As the Justice Department wrote in a memo to its minister in 1983, the referendum is retained only because governments prefer to let sleeping dogs lie and avoid the violent protest that the antiliquor force would certainly mount in the short term, ${ }^{219}$

Some Australian states adopted local option laws similar to those in New Zealand. In 1905 the New South Wales government replicated New Zealand's Alcoholic Liquors Sales Control Act so that triennial local option polls were held in conjunction with general elections. ${ }^{221}$ It therefore might reasonably be asked why Australian states were not similarly dogged with recurring prohibition referendums that inhibited reforms to the liquor laws. However there were important differences between the situation in

\footnotetext{
215 Fiditorial, Grey River Argus, 12 May 1959.

216 Bollinger, 1959 , p. 62 . 'This quote was untypical of Bollinger's book, as he did not advocate abolition of the triennial poll and seemed otherwise unaware of its importance in inhibiting reform. As noted earlier, even in 1967 he held onto the hope that voters would one day opt for state control.

217 As noted earlicr, in 1978 there was a 40 percent increase in the proportion of voters opting for prohibition and the number of prohibition voters reached an all-time high.

218 Report of the Select Committee on Violent Offending, dJHR 1979, 1-18. The proposal went no further.

219 (uoted by Stace, p. 193.

220 Lewis, A Rum State, p. 59.
} 
Australian states and New Zealand. As noted earlier, Pember Reeves adjudged the early Australian local option laws to be 'half-hearted affairs'.221 Once New Zealand-style local option was eventually established in some states the votes for reduction and no-licence tended to be small, just as they had initially been in New Zealand. The Victorian government's 1906 legislation cunningly delayed the commencement of local option until 1917, at which point it was further delayed due to the war. ${ }^{222}$ The government also set up a licensing authority to close down pubs, which took much of the heat out of the temperance issue. ${ }^{223}$ By the early 1920s all the other states except Queensland had followed suit. ${ }^{224}$ The fall in liquor consumption during the 1920 s and early 1930 s greatly assisted the ability of licensing authorities to close down hotels, and state governments were therefore able to repeal local option laws and cancel scheduled state-wide prohibition polls with relative impunity. By the time New Zealand had established a similar body in 1949 it was faced with the far more difficult task of trying to increase the number of pubs in many districts to cater for rising demand. The inevitable resistance of many voters to the possibility of new pubs in their neighbourhood did not create a hospitable environment for reducing government's reliance on referendums as an instrument of liquor policy.

\footnotetext{
221 Reeves, State Experiments, volume 2, p. 323.

222 Lewis, A Rum State, pp. 59-60, 66-7.

223 Irecland, The Awstralian Pub, p. 172.

${ }_{224}$ Freeland, The Australian Pub, p. 177. Queensland established a licensing board in 1935, Lewis, A Rum State, p. 75.
} 
FROZEN IN TIME

One of the most persistent problems in New Zealand liquor licensing was the grossly uneven distribution of licensed liquor outlets. From the 1890s to the 1950s it was all but impossible to open a new liquor outlet despite significant changes in the size and distribution of the population. As a result some areas were well-endowed with drinking facilities while others had few or none. Some considered that the restrictions contributed to overcrowded and unpleasant conditions in bars. It was primarily to deal with the 'maldistribution' problem, as it was commonly called, that the Royal Commission on Licensing was established in 1945. The commission's solution to the problem, if it can be called a solution, was to recommend the nationalisation of the breweries. The reasons for this controversial recommendation are discussed in this chapter.

The maldistribution problem came about because of the two fundamental beliefs that guided liquor control policy. One was the entrenched belief in the availability theory that if alcohol was easier to obtain people would drink more of it. The other was the belief that issues regarding alcohol had a special status that required them to be dealt with by way of public polls. Even within the limited circumstances that new liquor outlets were permitted, they were invariably subject to objection procedures and polling provisions that did not apply to any other type of facility. As a result of these entrenched beliefs it was difficult or at times impossible to open a new liquor outlet for over a century. It was as if the country had been frozen in time, from a drinker's perspective at least. Even after reforms in the early 1960 s, polling provisions and objection procedures made the opening of new outlets difficult and contributed to a phenomenon commonly known as 'booze barns'.

Until the 1950s one of the only ways a new pub could open was if a formerly dry district voted wet. Although local veto was abolished in 1918, parliament decided that liquor sales would remain illegal in no-licence districts until at least three fifths of the residents voted to restore licences. This did not happen in some districts for another 80 years. Meanwhile legislative anomalies for a time actually increased the proportion of the 
population living in dry districts, particularly in Auckland and Wellington. Many residents of dry suburbs saw advantages in their inherited ability to ensure pubs were located in neighbourhoods other than their own, thereby worsening the distribution problems. This chapter examines the persistence of no-licence during the twentieth century.

Another impediment to the establishing of new pubs was the traditional liquoraccommodation link. A requirement had been in place since at least 1881 that licensed publicans should also have rooms available to accommodate travellers. For several reasons including the capital investment involved, linking alcohol with accommodation provided an additional barrier to new players entering the market. While the link may have been intended to encourage the provision of accommodation, if anything it led to accommodation shortages in many areas due to the freeze on hotel licences. At the same time there were thousands of empty hotel beds throughout the country, as the Licensing Control Commission found when it surveyed hotels in the $1960 \mathrm{~s} .{ }^{1}$ The compulsory linking of liquor and accommodation meant hotels needed to be large and, combined with the shortage of pubs in many areas, helped put paid to the possibility that an institution comparable to the English local pub could ever develop in New Zealand.

\section{The Origins of the Distribution Problem}

As outlined in previous chapters, by the 1880 s two ideologies were taking hold in New Zealand after a period of relatively loose control over liquor sales. One was the idea, based on the availability theory, that the number of liquor outlets should be artificially restricted. The other was that the best method of imposing such restrictions was by determining the will of the people through elected licensing boards, petitions and referendums. In 1881 a new Licensing Act imposed a partial freeze on new liquor outlets. The country was divided into some 380 licensing districts with an average population of under 2000 people and annually elected licensing boards. ${ }^{2}$ Boards could approve a new liquor outlet only if a local option poll of ratepayers first agreed there could be more licences in the district. This proved a substantial barrier, for local option polls were held

\footnotetext{
I Licensing Control Commission Annual Report, AJI IR 1969, II.3.

2 T icensing . Ict, New Zealand Statutes 1881, pp. 127-182. The number of districts could vary as new ones were created and others merged, although in practice there was little change. There were 382 licensing districts in 1882 and 385 in 1890, AJHR 1882, H37 and IJHR 1890, H30, p. 7. The population figures used in the calculation are from N7OYB 1990, p. 128. Not all licensing board members were elected. Some were appointed and in many districts all members were appointed because the election produced no result or there were insufficient candidates. Ifter 1891 licensing board elections were held every three years.
} 
only once every three years, if at all. ${ }^{3}$ Opposition to new outlets was likely to come not only from the temperance faction but also from those associated with existing outlets threatened with competition. Even if ratepayers voted to increase licence numbers, boards did not have to take the poll into account - a likely outcome in the numerous districts in which only a handful of voters turned out. ${ }^{4}$ Of course approval of a new licence did not guarantee that someone would come forward to take it up, particularly given falling liquor consumption at the time. Finally, even if a new outlet got the goahead, local ratepayers had objection rights that could force a board to reconsider its decision. ${ }^{5}$ The importance of these barriers is shown by the fact that in the 1882 local option poll nearly a third of licensing districts voted to increase the number of licences, yet by 1894 the total number of licences nationwide had increased by just six percent. ${ }^{6}$ Meanwhile the county's population had risen by over 30 percent. $^{7}$ A way around the barriers to new outlets was a device known as a 'removal' whereby an unwanted licence could be transferred to another outlet. However the removal could take place only within a licensing district, making the provision of little value in those districts with a shortage of licences. $^{8} \quad$ This anomaly was exacerbated when in 1904 removals were limited to a maximum of one mile and in 1910 the objection provisions that could prevent removals were further tightened.' The limited ability to open new outlets and the complete inability to transfer redundant licences to areas they were needed meant that a highly skewed distribution of liquor outlets was inevitable if there were any significant changes in the distribution of the country's population.

The situation worsened once local veto was introduced under the Alcoholic Liquors Sales Control Act of 1893. The old licensing districts were scrapped and new ones created that were many times larger and congruent with electorate boundaries. The Act made it

${ }^{3}$ Licensing Ict, New Zealand Statutes 1881, p. 140. In 1882 many boards failed to conduct polls as required, AJHR 1882, II 37.

+ Licensing tct, New Zealand Statutes 1881, p. 141. In many districts less than a dozen voters turned out in the 1882 local option polls, two of which were decided by a single voter, AJHR 1882, H37.

5 Licensing Act, New Zealand Statutes 1881, p. 142.

6. The 1882 figure has been calculated from AJI IR 1882, II37. Four licensing districts put in no return and it has been assumed that each had a single liquor outlet comparcd with the national average of four. The 1894 figure is from N7. YYB 1998, p. 491. Ninety-eight of the 114 districts that voted to increase outlet numbers already had at least one public housc.

${ }^{7}$ Figure calculated form NZOYB 1990, pp. 127-8. The 1882 population was estimated from the 1881 census figure.

s. I.censing Ict, New Zealand Statutes 1881, p. 149.

"I Icensing . Icts Imendment . Ict, Nem Zealand Statutes 1904, p. 239 and Report of the Royal Commission on the Sale of Liquor 1974 , pp. 23,25 . The removal limit was half a mile in towns and cities. 
impossible for all practical purposes to increase the number of licensed hotels in a district. ${ }^{10}$ However their numbers could be reduced or bars could be eliminated altogether through a local poll, which after 1895 was held in conjunction with each general election. ${ }^{11}$ Following a no-licence vote, all hotels and their associated bottle shops within the district would close when their annual licences expired at the end of the following June. Under reduction, elected licensing boards decided which outlets, up to a maximum of 25 percent of the total, would close at the expiry of their annual licences. Under continuance there was no change in the number of liquor licences. ${ }^{12}$ Complex rules made reduction and continuance easier to carry than no-licence, which required a three-fifths majority. ${ }^{13}$ This form of local option remained in effect from 1894 until 1910, after which the reduction option was removed from the ballot. Although two more ballots enabling voters to close all local outlets were held after 1908, no more districts voted no-licence. For practical purposes local veto therefore ended with the last round of hotel closures after the 1908 ballot. Given the delays inherent in the system, this appears from published figures to have been in $1910 .^{14}$

Hundreds of publicans and their staff were put out of work through local veto. A total of 484 hotels lost their licences, 343 of them due to reduction and the remaining 141 in the 12 districts that voted no-licence. ${ }^{15}$ On the other side of the ledger 22 new hotels opened, presumably because they were approved before the 1893 legislation came into effect. The overall outcome was a 27 percent reduction in hotel numbers within 16 years, from 1719 to $1257 .^{16}$ These reductions took place during a period when the population of the colony was still growing rapidly. The population grew by 40 percent between 1894 and 1910 ,

\footnotetext{
${ }_{10}$ Alcoholic Liquors Sale Control Act, New Zealand Statutes 1893, pp. 127-140. In theory the number of hotel licenses in a district could be increased if the census showed a 'sudden' population increase of at least 25 percent and a petition signed by at least 25 percent of the electorate was presented to the licensing committec, who could then authorise a special poll. In increase in licence numbers would then be allowed if it was supported by at least 60 percent of voters - providing at least half of those on the roll turned out to vote. Not surprisingly there is no record of these conditions having ever been met. 'The Ict did not initially apply to chartered clubs and wholesalers but these were later included.

$"$ Alcoholic Liquors Sale Control Amendment Ict, New Zealand Statutes 1895, p. 164.

12 Alcoholic Liquors Sale Control Act, New Zealand Statutes 1893, pp. 127-140, Reeves, State Experiments, volume 1, pp. 310-11, Royal Commission on the Sale of I iquor 1974, pp. 23-4.

13 Voters could choose more than one option, and in the first poll in 1894 unsuccessful no-licence votes were added to those for reduction, resulting in the closure of numerous hotels.

14 The data on hotel numbers appears to have been collected each May, meaning that the hotel closures in July 1909 would not be reflected in the official figures until 1910 .

15 Cocker and Murray, pp. 271-2. Is an example, 16 hotels lost their licences when Invercargill went dry in 1906, four of which remained open to provide accommodation only, De la Mare, Drinte or Drought, p. 72.

16 NZOYB 1998, p. 491.
} 
from 721,000 to over a million. ${ }^{17}$ The effect of the licence reductions is much more dramatic once this population increase is taken into account. Figure 4.1 shows that the real number of hotel licences halved within 16 years. In 1894 there were 2.4 hotels to every 1000 people; by 1910 just 1.2 . To put it another way, there was a hotel to every 400 people at the start of the period and one to 800 by the end.

Although local option polls were discontinued in all but dry districts in 1918, the number of hotels continued to decline because of occasional closures and the lack of effective provisions for new pubs to open. From the 1890 s to the 1950 s almost the only new licensed hotels established were in formerly dry areas that voted to go wet again. ${ }^{18}$ In theory a new licence could be granted under the removal provisions if an existing hotel closed, providing that the new hotel was built within half a mile of the old one, or a mile in country areas. ${ }^{19}$ But applications for removals were subject to an objection process through which objectors could simply claim that a new hotel was not needed. ${ }^{20}$ The 'need' criterion for new licenses survived in various forms until 1989. Those arguing there was no need for a new licence were often current licence-holders whose business might be threatened with competition. ${ }^{21}$ The effects of the legislative changes, particularly in 1893 , can be seen from the example of Dunedin, where 45 hotels were closed under local veto between 1894 and 1909.22 In contrast, just one new hotel was built in Dunedin in the 75 years after 1890, when in 1902 the Shamrock hotel transferred to a new site. ${ }^{23}$ The restrictions imposed a similar freeze on the rest of the country, although obviously not all districts shared Dunedin's relatively slow rate of population growth.

\footnotetext{
17 N7OYB 1990, p. 128.

is Stacc, pp. 1-2.

19) In 1955 the limit was increased to five miles and was further increased to ten miles in 1960 and 20 miles in 1962 , I icensing Imendment. Ict, New Zealand Statutes 1960, p. 689 and Sale of Liquor Ict 1962, New Zealand Statutes 1962, volume 3, p. 1182. In 1964 the transfer distance was extended to 50 miles and in 1971 it was made unlimited, Stace, pp. $153,165$.

20 Licensing Act, New Zealand Consolidated Statutes, Appendix D, volume 3, 1908, p. 636.

21 Working Party on Liquor, p. 197.

22 Frank Tod, Pubs Galore: History of Dunedin Hotels 1848-1984, Dunedin, 1984, p. 6. . Il hotel closures in Dunedin came about because of the reduction option in the local licensing poll.

${ }^{23}$ Tod, Pubs Galore, p. 38.
} 
Figure 4.1: Number of Licensed Hotels per 1000 People, 1894-1910

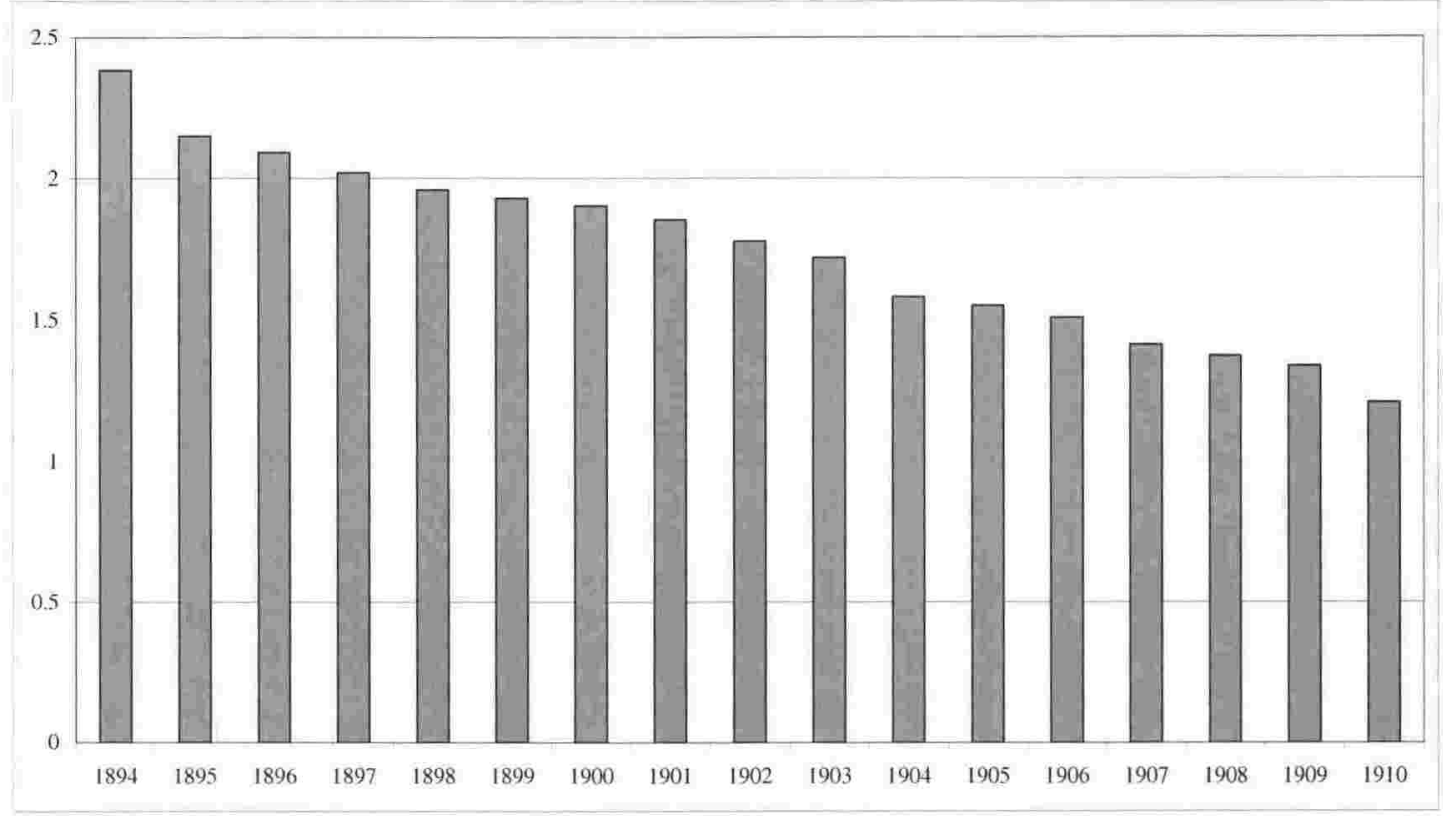

Source: Figures calculated from NZOYB 1896-1913 and 1990

In 1939, with the 1881 Licensing Act still in force and the freeze on new hotels still in place, the Justice Department questioned the common sense of late colonial legislators. 'The framers of the existing law would appear to have assumed that the population of the country would remain static,' said a departmental memorandum to the Minister of Justice $^{24}$ But of course the population did not remain static. The population grew and its distribution changed. While the majority of people lived in the South Island in the 1880s, by the 1930 s South Islanders were outnumbered nearly two to one. ${ }^{25}$ Small towns grew and the larger cities acquired substantial suburbs where there had once been farmland or native bush. Growing towns such as Whangarei, Hamilton, and Hastings were left with minimal drinking facilities. ${ }^{26}$ In 1945 greater Auckland had 80 hotels spread over 11 electorates that had a combined population of 273,000 , while the Westland electorate had 73 hotels and a population of under $19,000 .^{27}$ Yet a reading of the parliamentary debates of the late nineteenth century reveals no awareness among MHRs that a freeze on the number and distribution of hotels might conflict with demographic change. Robert

\footnotetext{
$2+$ PRCI., p. 37.

25 ligure calculated from N'KOYB 1990, p. 129.

26 Report of the Royal Commission on Licensing 1945, p. 198.

${ }^{27}$ Figures derived from Report RCI, pp. 197-8.
} 
Trimble was a rare voice in opposition to the freeze. Referring to official statistics showing a marked decline in alcohol consumption and drunkenness convictions over the previous decade, Trimble rhetorically asked in 1881, 'why, with these encouraging figures before you, do you not let well alone?'. ${ }^{28}$

Areas such as Otago and the West Coast, where the population was static or shrinking, appeared to have more than enough hotels, but even on the Coast there were distribution problems. Some towns were left without a pub by historical accident while others had plenty. The Runanga miners told the 1945 Royal Commission on Licensing that a hotel was needed in Stockton, a town with no pubs. ${ }^{29}$ Nearby Millerton had two licences, but both were held by the same person who kept one hotel boarded up to save costs. The restrictions on new licences protected the owner from any risk that a competitor might offer a choice to drinkers, either in the same town or one nearby. ${ }^{30}$ Submissions to the royal commission also drew attention to the lack of licensed facilities at the tourist resorts at Fox Glacier and Lake Ianthe. ${ }^{31}$ In 1967 a newspaper correspondent on behalf of 'some of the boys at Haast' lamented the lack of a pub there. 'At the present rate of progress it might be another 100 years before we get one. ${ }^{32}$

\section{The Royal Commission on Licensing}

By the late 1930s the Justice Department considered that the problem of licence maldistribution had reached the point of absurdity and recommended the government establish a royal commission, although the intervention of the war meant that the commission was not actually set up until 1945. Many making submissions to the Royal Commission on Licensing drew attention to the problems of overcrowding and poor facilities in bars. ${ }^{33}$ Some blamed the shortage of pubs and lack of competition in many areas for the problems and proposed a return to something akin to the pre-1881 system whereby the issue of licences was restricted primarily by the suitability of applicants. ${ }^{34}$

\footnotetext{
${ }^{28}$ NZIPD 1881, volume 38, p. 58.

29 PRCI , p. 5408.

30 PRCL, p. 5411.

31 PRCL, pp. 5268-9, 5369. Witnesses also commented on the lack or shortage of licensed facilities in other tourist areas, PRCI, volume 53, p. 95.

32 Otago Daiby Times, 20 September 1967, p. 4. Haast now has a pub.

${ }^{33}$ Sec Chapter 3 for details.

${ }^{34}$ See, for example, PRCL pp. 1435-44, 1527, 1859, 2415, 5377-8, 5389.
} 
Those advocating such a liberalisation of the licensing laws were largely ignored. The commission never seriously considered that making licences easier to obtain might be a solution to the problem of overcrowded bars. Instead it advocated bigger bars, foreshadowing the later fashion for booze barns. ${ }^{35}$ The commission considered the Newmarket Hotel, with an enormous bar accommodating 500 to 600 people, to be an exemplar for other hotels to follow. ${ }^{36}$ In its attempts to grapple with the licensing problem the commission made some controversial recommendations, none more so than its proposal that the government buy the country's 42 breweries. The commission's recommendation to nationalise the breweries was related to the freeze on licences. The freeze caused breweries to compete to acquire outlets for their beer, thereby forcing up the price of hotels and leading to a proliferation of tied and managed houses. According to the commission, expensive leases under brewery ownership meant publicans tended to neglect the accommodation side of the business and increase liquor sales through legal and illegal means. The only way to end this unhealthy competition was through a brewing monopoly. The commission considered a private monopoly undesirable and a state monopoly would therefore provide the only lasting solution. ${ }^{37}$

Why the commission made such a seemingly bold recommendation is something of a mystery. Nationalisation was not supported by the Alliance or the liquor trade, and was advocated by only a handful of those making submissions. Private ownership of the trade is 'on the evidence to date, better than State ownership' the Alliance counsel told the Commission. ${ }^{38}$ Little evidence was presented by the Alliance on this issue, but the international prohibition movement was traditionally antipathetic to the idea of state control, for it appeared to give community endorsement to liquor sales. For example the Swedish non-profit system that originated in Gothenburg was criticised by the Alliance in a 1908 monograph. ${ }^{39}$ In 1926 freelance journalist and poet Jessie Mackay contributed a series of articles to the WCTU newspaper The Wbite Ribbon that painted an unflattering picture of experiments in community ownership of liquor outlets. ${ }^{41}$ The articles dealt with

\footnotetext{
35 Making bars larger was for some reason not considered to increasc the availability of alcohol.

${ }^{36}$ Report RCI, p. 113. The bar was so large that it even had tables and chairs, a fact considered highly commendable by the Commission.

37 The Commission's report never laid out its argument for nationalisation in a clear and logical way. However the basic argument can be discerned from pages 279, 311 and 317-19.

38 PRCl, p. 7250.

${ }^{39}$ George Dash, ed, No-Liense Handbook, Auckland, 1908, pp. 69-70.

to The Wbite Ribbon, 18 May 1926, pp. 1-2, 18 June 1926, pp. 4-5, 18 July 1926, pp. 3-4, 18 . August 1926 , p. 9.
} 
experiments in community control of liquor distribution in Scandinavia, Scotland, North America and Australia. In 1946 the Alliance issued a pamphlet entitled Control Fails, which criticised state ownership in some Canadian provinces. ${ }^{41}$ In fact the system of state ownership proposed by the commission bore little resemblance to these various overseas examples and its members seemed unimpressed with the Canadian system. ${ }^{42}$

The nationalisation recommendation was rejected by three of the eight surviving members of the commission (one died shortly after the hearings ended), all of whom wrote minority reports. ${ }^{43}$ State control, wrote George Hutchinson, 'has been steadfastly rejected by the electors at every licensing poll',4 Frederick Young, a senior Labour Party official and prominent trade unionist, described the proposal in a press release as 'totalitarian' ${ }^{45}$ In his minority report he rhetorically asked 'what possible justification exists for the creation of a State monopoly, which completely eliminates even a vestige of competition? ${ }^{40}$ When the Commission's report was first made public in September 1946, the media was likewise sceptical. While welcoming some of the recommendations, the Otago Daily Times described the nationalisation proposal as 'strategically hopeless', given that electors had shown little enthusiasm for state control in regular referendums. ${ }^{47}$ The Dominion editorialised that other state ventures into trading enterprises had produced little public benefit. 'On the contrary, there is a very good reason to fear that such a change would produce greater ills than those that may already exist. ${ }^{48}$

A vox pop exercise conducted by the Auckland Star found one supporter for nationalisation, a waterside worker who considered that with a state owned brewery 'a better standard of beer would be produced'. ${ }^{49}$ DB boss Jack Kelleher disagreed. 'The viewpoint of the majority of the commission that the removal of all competitive factors in the industry would be beneficial is contrary to all accepted principles... To expect better beer, better

\footnotetext{
${ }^{41}$ W. H. Milner, Control Fails, Wellington, 1946 in New Kealand Alliance Records, 77-206-06/07, Alexander Turnbull I ibrary.

\$2 Report RCJ, p, 318.

43 Thomas Macky dicd in carly 1946.

H Report RC:L, p. 399.

45 Dominion, 5 September 1946, p. 6.

t6 Report RCJ , p. 419.

${ }^{47}$ Otago Daily Times, 6 September 1946, p. 6.

ts Dominion, 5 September 1946, p. 6.

49. Amteland Star, 4 September 1946, p. 3.
} 
service and better accommodation from such a glorified state monopoly is ludicrous in the extreme. ${ }^{50}$ Kelleher's statement appears to have been the only trade comment on the issue reported in the mainstream media at the time. However when Labour candidate Warren Freer met with New Zealand Breweries head Ernest Davis in 1947, Davis stressed his strong opposition to brewery nationalisation. ${ }^{51}$ Davis was a long-standing Labour supporter and Freer appears to have reassured him on the nationalisation issue; the meeting was reportedly followed by a substantial donation to party campaign funds. ${ }^{52}$

When the Royal Commission's report was finally discussed by Parliament over a year after its release, two Labour MPs spoke in favour of nationalisation. 'It is the profit motive that leads to people drinking more than they should,' said the member for Palmerston North. ${ }^{53}$ The proposal also received support from some unions and Labour Party branches. ${ }^{54}$ However there was little reason to expect the Government would nationalise the breweries. While Labour added new monopolies to the state's portfolio during its first decade in office - broadcasting, internal airways and the linen flax industry - it mainly relied on broad instruments such as control of credit, social legislation and regulation to achieve its ends. ${ }^{55}$ Industry nationalisation was not on the agenda of Labour leaders Fraser and Nash, who only reluctantly agreed to the nationalisation of the Bank of New Zealand in 1945 to ensure party unity. ${ }^{56}$ Interestingly, party membership agitation for the BNZ nationalisation was led by Frederick Young, the same royal commissioner who so vehemently rejected the proposed nationalisation of the brewing industry. ${ }^{57}$ His opposition would have made senior Cabinet members even less likely to consider the proposal. Admittedly Labour nationalised the coal industry in 1948, although this was largely with the support of its owners. ${ }^{58}$ As already noted, brewing industry bosses were

\footnotetext{
50 Awkland Star; 5 Scptember 1946, p. 3.

51 Warren Freer, A Lifetime in Politics, Wellington, 2004, p. 26.

52 Freer, p. 26. For Davis' support for Labour see Freer, p. 26 and Graham Bush, 'Davis, Ernest I Iyam 1872 - 1962 '. Dictionary of New Kcaland Biography, updated 16 December 2003, URL: http://www.dnzb.govt.nz/.

53 NZPD 1947, volume 278, p. 591. The delay in the report being discussed by Parliament was due to the intervening general election and the resources needed to print sufficient copies of the 450 page report.

it Steven Ficrgusson, 'Class at the Margins: The Canterbury Hotel Workers' Union 1908 to 1978', MA thesis, University of Canterbury, 1985, p. 162.

55 Keith Sinclair, A History of New Zealand, Revised Iidition, Iuckland, 2000, p. 285 and Michael Bassett, The State in Nem Zealand 1840-1984: Socialism Without Doctrines?, Auckland, 1998, chapters 7 and 8.

56 Keith Sinclair, Walter Nash, Auckland, 1976, pp. 243-4.

57 Sinclair, Whalter Nash, p. 244.

58 Bassett, The State in New Zealand, pp. 248-250.
} 
not similarly inclined to support nationalisation. Public support was also minimal, as indicated every three years in the General Licensing Poll. ${ }^{59}$ 'I think members will agree that the sentiment of the people is unlikely to be in favour of taking over the breweries,' Justice Minister Rex Mason told parliament when introducing the Licensing Amendment Bill in 1948. ${ }^{(H)}$

While nationalisation received little support in the evidence presented to the Commission, support did come from three influential sources; the Federation of Labour, the Trades Council and the Anglican Church. ${ }^{61}$ Other supporters were a police constable from Otaki, the Wellington City Missioner, and a group of workers from the Hutt railway workshops. ${ }^{12}$ Only the Church of England submission outlined in any detail how state ownership might work in practice, through a state owned corporation that would run the breweries. ${ }^{63}$ The Church had advocated variations on this theme from time to time, beginning in the period 1896 to $1903 .{ }^{6.4}$ In 1923 a serious proposal for 'corporate control' was put to the government by an alliance of Anglicans and brewery interests - the latter no doubt searching for a way to stave off the then-regular threat of prohibition. ${ }^{65}$

But the main responsibility for the nationalisation recommendation appeared to come from a surprising source - the Department of Justice; or rather, from its autocratic boss Berkeley Dallard. Dallard had been under-secretary to the Department of Justice since 1933. According to Greg Newbold, he was an authoritarian leader 'who ran his department with a minimum of delegation?. ${ }^{66}$ He involved himself in administration at all levels and demanded servility from his subordinates. Most departmental activity was reputedly taken on his initiative. ${ }^{67}$ Dallard himself did not openly advocate public ownership of the liquor industry in his report to the Royal Commission, although he did put at length an argument that the industry was an ill-controlled monopoly. However his

\footnotetext{
5y) Ironically there was a 50 percent increase in the vote for State Control in the 1946 poll, presumably because of the royal commission's recommendation, but this increased support disappeared in 1949.

(6) NZPD 1948 , p. 4193.

${ }_{61}^{6}$ PRC., PP. 1815, 5522-4, and volume 53 p. 126.

62 PRCI, pp. 1413, 1379-89, 1830.

63 PRCL, pp. 5522-4.

it Grigg, 'Viable Option or V'ote Splitter?', p. 16.

${ }^{65}$ Report RC.L, pp. 51-2.

66 Greg Newbold, 'Dallard, Berkeley l.ionel Scudamore 1889 - 1983', Dittionay of New Zealand Biograpby, updated 4 . April 2003, http://www.dnzb.govt.nz.

67 Newbold, 'Dallard, Berkeley Lionel Scudamore'.
} 
report laid the foundations for what was to come. The counsel representing the Crown, appointed by the Justice Department, used it to strongly advocate for nationalisation. It may well be that the Crown Counsel, J.D. Willis, was acting on his own initiative, but this seems unlikely if Newbold's portrait of Dallard has any veracity.

Willis' summing up of the evidence on behalf of the Crown is particularly striking. It took over a day of the hearings, and filled 150 pages of the notes of the proceedings. While ostensibly summarising the evidence presented to the Commission, in actuality Willis did very little of that. Nearly half of his presentation could fairly be described as special pleading for the nationalisation of the liquor industry. Willis claimed that many witnesses had supported state control, but in reality the main advocate during the proceedings had been himself, abetted by Dallard. 'In New Zealand today it is quite apparent that there is a state-created monopoly which benefits certain private interests,' Willis told the Commission. ' $[T]$ he manufacture, the distribution, the sale, and...the price of liquor, are all in the hands and control of a select group, ${ }^{68}$ Failure to control the monopoly effectively and 'exploitation of that failure by the trade' had led to the existing conditions. $^{69}$ He argued that the freeze on hotel, brewery and wholesaler's licences led to competition to acquire these assets and their concentration in fewer and fewer hands. Tied and managed houses abounded as breweries increasingly bought up hotels as outlets for their beer. This competition forced up hotel prices, necessitating ever-greater profits for an adequate return on capital..$^{70}$ The result was poor service and conditions, illegal practices and high liquor prices, he claimed. ${ }^{71}$

This then, is the first leg of the argument, and much of its substance can be found in Dallard's original report to the Commission. The second leg of the argument concerns the remedies for the evils that had resulted from this government-mandated monopoly. Here, Willis indulged in a little sleight of hand. He argued that there were only two ways of controlling the liquor traffic other than banning it outright; through licensing, or through a state monopoly. The licensing system clearly was not working, as exemplified by poor drinking conditions and widespread law-breaking. So there were just two options, argued Willis. One was to abandon the licensing system altogether and leave the

\footnotetext{
${ }^{68}$ PRC. , pp. 451-2.

${ }^{69}$ PRCL, p. 7677.

70 For more detail on this argument, sce especially PRCL. pp. 7681-7714.

71 PRCL, PP. 7696.
} 
sale of liquor completely unrestricted. After he had knocked down this particular straw man there was only one option left - state monopoly. ${ }^{72}$

Willis told the Commission that the benefits of state ownership of the industry included abolishing the profit motive, eliminating goodwill payments, tightening controls, and diverting profits to worthy causes. ${ }^{73}$ 'By vesting the trade in a State Department or public corporation, the circumstances which stimulated demand disappear and with it the illegalities and certain abuses. ${ }^{74}$ There is, he said, 'a considerable body of evidence in favour of straight out state ownership of the whole industry. ${ }^{75}$ The alternative was private control with its 'tied house system, good wills and excessive profits'. ${ }^{76}$ He invited the commission to 'ask itself whether there is any hope of true reform in the trade so long as brewing remains in private hands. ${ }^{77}$ It was an extraordinary performance, coming at the very end of the Commission's hearings. In some ways it is not surprising that commission members grasped hold of a seemingly coherent argument when faced with nearly 8000 pages of often irrelevant and confusing evidence.

Clearly there were a number of faults with Willis' argument. As Sidney and Beatrice Webb had pointed out over 40 years earlier, the high prices paid for pubs did not automatically lead to illegal trading and poor conditions to ensure a decent financial return. The prices paid often reflected a desirable location and protection from competition; factors that would naturally result in good returns. ${ }^{78}$ Characterising the industry as a monopoly also rather overstated the case. Certainly the heavy restrictions resulted in hotel monopolies in many districts, but in others there was ample competition. Furthermore, there were 42 breweries owned by 30 different companies - hardly a monopoly situation. ${ }^{79}$ Willis' attack on brewery-owned tied and managed hotels was not supported by any evidence of substance. While a clear majority of hotels were owned by or in some way connected to breweries or wholesalers, no evidence was presented to the royal commission of more problems with after-hours trading in such houses, or that

\footnotetext{
72 PRCI., p. 7714-5.

73 PRCl, p. 7715.

${ }^{7+}$ PRC:L, p. 7716.

75 PRC.L, p. 7715.

76 PRCJ , p. 7726.

77 PRCL, p. 7811.

78 Wcbb, The History of I iquor Licensing in England, pp. 92-3.

79 PRCLL, pp. 1231-2.
} 
drinking conditions were any worse there, or that the alcohol was of lower quality or more expensive. Again, the Webbs made a similar point when referring to the report of an English select committee that looked at tied houses in the early nineteenth century - there was no evidence presented by that committee that such pubs had lower quality or more expensive beer, they said. ${ }^{80}$ The Hotel Workers Union testified to the commission that it saw no problem with tied houses, as did some publicans. ${ }^{81}$ More significantly, a magistrate who had sat for decades on licensing committees testified that he knew of no abuses of the tied house system. ${ }^{82}$ Nine years later a New South Wales royal commission reported that it found no problem with tied houses. The Commission concluded that the most constructive approach to reform was to concentrate on amending the licensing laws rather than worrying about restraints on trade. ${ }^{83}$ Economic historian Tim Mulcare recently argued that brewery-owned tied and managed houses were largely positive for New Zealand consumers. He claimed they enabled breweries to obtain a stable outlet for their draught beer close to where it is brewed, leading to improved quality and lower transport costs. ${ }^{84}$ In addition, the ownership and close management of hotels by breweries helped avoid adulteration of their product. Breweries had a reputation and brand names to protect, providing an incentive to ensure consistent quality beer in the pubs they owned. ${ }^{85}$ Finally Mulcare argued that, far from pushing up hotel expenses, exclusive deals helped keep down rents and financing costs for publicans. ${ }^{86}$ There are compelling counter-arguments to all these points - consistent quality beer can mean lack of choice and mediocrity - but few arguments either for or against tied houses were raised in the commission's hearings.

Of course even if all Willis' arguments about the evils of monopoly and tied houses were valid, the nationalisation recommendation does not necessarily follow. The sole alternative to nationalisation was not to abandon the licensing system altogether; another option was to reform it. The view supported by the majority of commissioners that private control was responsible for poor drinking conditions would appear to be ill-

\footnotetext{
${ }_{80} \mathrm{Wcbb}$, The Histary of I iquor Liensing in England, p. 91.

${ }^{81}$ PRCL, pp. 5368, 7144-5.

82 PRC.L, p. 6531.

${ }^{83}$ Kirkby, Barmaids, pp. 179-80.

8.t Mulcare, 'Control of Alcoholic Beverage Markets', p. 143.

85 Mulcare, p. 130

86 Mulcare, pp. 114, 118.
} 
founded. They allowed themselves to be overly influenced by Willis, who was presumably a mouthpiece for Berkeley Dallard. Why Dallard should support nationalisation of the breweries is unclear, although he did head a large state organisation as controller general of prisons. ${ }^{87}$ More prosaically, he may simply have been convinced by the arguments put forward by nationalisation advocates Rowntree and Sherwell at the turn of the century. ${ }^{88}$ The arguments used by the Justice Department in 1945 in favour of state control are remarkably similar to those used by these writers. However the nationalisation recommendation may have come about, ultimately it was motivated by the fact that the royal commission was unwilling to propose reforms to the licensing system that would dilute or abandon the availability theory on which the system was based.

\section{The Licensing Control Commission}

One problem confirmed by the hearings of the 1945 royal commission was the poor standard of hotel drinking facilities and accommodation. As will be seen in later chapters, complaints included lack of hygiene, poor ventilation, lack of lighting and furniture, and overcrowded drinking conditions. The government accepted the Royal Commission's recommendation that a national body be established to police hotel standards and redistribute licences in a more sensible way. ${ }^{89}$ As a result the Licensing Control Commission (LCC) was set up in 1949, although it made little impact in its first decade or so. Because there was a restriction on the national number of licenses allowed, success of the redistribution policy depended largely on the LCC's ability to close down pubs considered unnecessary. ${ }^{99}$ It effectively lost this ability after a 1953 Supreme Court decision set compensation at a level it could not afford. ${ }^{91}$ In addition, the LCC had no permanent staff and limited powers to police hotel standards. ${ }^{92}$ According to Bollinger, drinking conditions had improved little by $1959 .^{93}$ While in 1945 the industry had the excuse of the depression and war to blame on the poor quality of many hotels, by the

\footnotetext{
87 Greg Newbold, author of the entry for Dallard in the Dictionary of New Zealand Biography, says he would not be surprised if he was an advocate of nationalising the liquor industry (personal communication).

88 Rowntrec and Sherwell, The Temperance Problem and Social Reform, Chapter V1 'The Solution of the Problem', and Public Control of the Liquor Traffic.

89 Report RCI, p; 282.

${ }^{9}$ In 1948 the government further reduced the national number of licenses allowed, Licensing Amendment Act, New Zealand Statutes 1948, volume 2, p. 932.

91 Stace, p. 2.

${ }^{2}$ Stace, p. 149.

${ }^{3}$ Bollinger, 1959, pp. 13-14.
} 
1950 s it was clear that the main culprit was the minimal incentive for improvements due to lack of competition and inadequate enforcement mechanisms.

The LCC's powers were boosted considerably in the early 1960s. It could appoint hotel inspectors, set minimum hotel standards and had a greater say over the closure of hotels and the issuing of new licenses. Parliament abolished the absolute limits on the national number of licences and loosened restrictions on removal of unwanted hotel licenses. All existing hotel licences were made provisional, thus putting the onus on owners and managers to show they conformed to the required standards. The LCC began a lengthy process of hearings and hotel inspections throughout the country, although its suggested changes were initially met with stout resistance by an industry with little commercial incentive to improve its facilities. At its first hearings in Levin in 1963, publicans objected to suggestions they should provide seating in bars and hand basins in hotel rooms. ${ }^{94}$ The LCC reacted to this resistance by agreeing on a set of hotel standards with the Hotel Association, ${ }^{15}$ and Bollinger acknowledged in the second edition of his book that these standards, along with the commission's increased powers, did much to improve drinking conditions. ${ }^{96}$ But the changes did little to solve the distribution problem, as the LCC stated emphatically in its 1965 annual report. "The rational location of licensed premises is the most intractable problem in the licensing field. It is beyond the powers of the Commission to wrestle with it, and there are no statutory guidelines or effective directions that are at all likely to ameliorate it. ${ }^{57}$

A major hindrance to the commission's work was the provision put in place in 1948 that enabled local residents who objected to a proposed new hotel to demand a poll on the proposal. ${ }^{98}$ Thus new hotels faced several barriers. They first needed the approval of the LCC, which was legally required to apply the 'need' test that protected existing providers from competition. Once approved, hotels not only needed to conform to local town planning requirements but also faced a substantial risk of being voted down by a majority of local residents. This was an improvement on the previous situation where no new licenses were allowed at all, but the costs and uncertainties in the process were a

\footnotetext{
${ }^{24}$ Stace provides a detailed discussion of these changes, pp. 149-153.

${ }^{95}$ Stace, p. 151.

${ }^{96}$ Bollinger, 1967 , pp. $174-5$.

${ }^{97}$ J.IC 1965 Innual Report, IJHR 1965, H3, p. 6.

98 These provisions were later incorporated in the Sale of I iquor Ict 1962, Nen Zealand Statutes 1962, volume 2, pp. 11469.
} 
significant disincentive to the establishment of new hotels. As the LCC said in its 1967 annual report, 'none but the doughty or well heeled... can build a hotel in under three to five years after it is authorised by the Commission'.? Despite the LCC's pessimism, the lessening of restrictions on licence removals appeared to have had some effect. For example four new pubs were established in Dunedin between 1960 and 1984 because of the less stringent provisions. ${ }^{101}$ While not a dramatic expansion, these were Dunedin's first new pubs since 1902 .

Although significant restrictions on new hotels remained in place, restrictions lessened in other areas. In 1948 Labour ended the 40-year freeze on new chartered clubs. As a result the number of clubs legally able to sell alcohol to members gradually expanded from 46 to 326 over the next 30 years. ${ }^{111}$ While a new 'winesellers' licence was also introduced in 1948 , outlets were initially few because of the unpopularity of wine and the two gallon minimum placed on sales. ${ }^{112}$ However the number of wine shops grew dramatically once the limit was reduced to a quart in 1955 and demand for wine increased after Arnold Nordmeyer's 1958 'black budget'. ${ }^{113}$ The government further sidestepped the availability restrictions from the early 1960s by introducing new types of licence such as those for restaurants and airports. For the first time in nearly a century the number of new outlets kept pace with population growth. ${ }^{114}$ This trend continued and by 1989 there were so many different types of licence that official sources were unclear as to their exact number. $^{105}$

\section{The Alcohol-Accommodation Link}

It was not just licensing restrictions that led to a dearth of bars in many districts. Other restrictions had an even longer history. In addition to the availability theory and the belief that alcohol should be the subject of constant referenda, there was a third entrenched belief underpinning liquor policy in New Zealand. This was the notion that it was

\footnotetext{
(2) LCC 1967 Annual Report, AJHR, 1967, H3, p. 9.

100 Tod, Puls Galore, pp. 43-61.

101 Licensing Amendment Act, Nem Zeatand Statutes 1948, Part IV, p. 969, Report RCL, p. 236, Licensing Control Commission Innual Report, AJHR, L:8, 1981.

102 Licensing Amendment Act, New Zealand Statutes 1948, volume 2, pp. 964-6.

103 Stace, pp. 67-8, 71. By 1980 there were 376 'wine resellers' licences as they were then known, LCC Annual Report 1980, AJHR 1980, E.8, p. 7. The 1958 budget doubled the dutics on beer and spirits but left wine untouched.

${ }^{10+}$ Alcoholic Liquor Advisory Council, Living with Alcahal: Preventing Misuse, Wcllington, 1983, p. 6.

105 See NZOYB 1990, p. 567 and Working Party on Liquor, p. 49.
} 
unprofitable to provide accommodation for travellers and that market intervention was therefore needed in the form of a legal requirement that almost anyone licensed to sell alcohol to the public should also provide accommodation. ${ }^{106}$ The requirement possibly derived from the English tradition of coaching inns that supplied overnight travellers with much-needed food and board. ${ }^{107}$ In the more sparsely populated Australasian colonies with unreliable transport links, such overnight accommodation was often seen as an essential service requiring legislative coercion. As most public houses also provided accommodation it was perhaps seen as logical to impose the same requirement on all of them. In New Zealand some provincial governments imposed stabling and accommodation requirements on licence-holders, partly to try to improve hotel standards by putting undesirable 'grog shanties' out of business. ${ }^{108}$ However in the main such measures appear to have been aimed at trying to ensure that sufficient accommodation was provided in an era when transport systems were notoriously unreliable. Those seeking to travel any distance often had to put up with slow and uncomfortable roads that necessitated frequent and sometimes unplanned overnight stops. ${ }^{1(1)}$ This was certainly the rationale given by a Government Minister when introducing an unsuccessful licensing bill in 1871, claiming it was 'a general complaint in many parts of the colony, that public houses had not sufficient accommodation for travellers'. ${ }^{110}$ The Bill proposed to extend the liquor-accommodation link then in place in Auckland Province to the rest of the country. This eventually happened when the 1881 Licensing Act consolidated provincial legislation and required all urban public houses to provide at least six bedrooms for the travelling public, plus stabling for horses at the discretion of licensing committees. The requirements for rural inns were less stringent, as local licensing committees had the discretion to require rural publicans to maintain nearby bridges or pay a fee in lieu of providing rooms for accommodation. ${ }^{111}$

Ironically by the time the liquor-accommodation link was established in law, the accommodation needs of the colonies were already changing due to the spread of the railways. Many small town hotels soon became redundant as anything other than drinking

\footnotetext{
106 The main exceptions to this requirement were liquor wholesalers and chartered clubs.

107 Peter I Iaydon, The English Pub: A History, London, 1994, pp. 137-169.

108 Fildred-Grigg, Pleasures, pp. 64-67, 82.

${ }^{109}$ James Watson, Links: A History of Tramsport and New Zealand Saciety, Wellington, 1996, pp. 99-101.

110 NZPD 1871, volume 11, p. 331.

111 Licensing Act, New Zealand Statutes 1881, pp.136-7. The stabling requirement was removed in 1948.
} 
establishments 'as rail-borne travellers rumbled quickly past to their destinations in larger centres, and locals had little need to stop overnight'. ${ }^{12}$ In Patea, for example, several hotels closed or reverted to drink shops in the 1880 s as road and ferry customers were lost to the railway. ${ }^{113}$ A similar process had occurred in England some 30 years earlier once the railways put most coaching services, and the inns that serviced their customers, out of business. ${ }^{114}$ The changing face of New Zealand transport appeared to have made the original rationale for the liquor-accommodation link redundant. Despite this, 'the illogical automatic yoking of bar business with bedroom accommodation' stayed in place for over a century. ${ }^{115}$

Once it became compulsory for public house owners to provide accommodation, a linguistic transformation gradually took place. Nineteenth-century parliamentarians commonly used the words 'inn' and 'public house' in debates. By the time the 1945 Royal Commission on Licensing sat in 1945, the use of the terms 'hotel' and 'bar' to describe a pub appeared to be universal, while the uninformative term 'private hotel' was used to describe a hotel not licensed to sell alcohol. Industry representatives in particular favoured the word 'hotel', perhaps to reinforce the accommodation connection, although it was not until 1959 that the Licensed Victuallers Association changed its name to the Hotel Association. ${ }^{16}$ Significantly the change came at a time when the liquoraccommodation link was seriously threatened for the first time. After the tavern licence was introduced in 1961, the word 'tavern' took on its distinctive New Zealand meaning of a public house not required to provide accommodation. ${ }^{17}$ When James McNeish wrote a book on New Zealand drinking establishments in the 1950s, he deliberately used the word 'inn' throughout to try to encourage its revival, which he saw as desirable because of its 'homely ring' and historic associations. However he had to admit that the more sterile word 'hotel' was 'now above every publican's door'. ${ }^{118}$ The New Zealand Oxford Dictionary gives the primary definition of 'hotel' as 'public house or pub', a usage largely peculiar to

\footnotetext{
112 Watson, Links, 1996, p. 115.

113 Jason Wright, 'Company of Strangers: Patca and Wanganui Hotels, 1866-1899', ML thesis, Massey University, 2004, pp. 9-10, 24.

114 Haydon, The English Pub, pp. 148, 168-9.

115 Bollinger, 1967, p. 164.

116 Brien, 100 Years of Hospitality, p. 70.

117 Filizabeth and Harry Orsman, The New Zealand Dictionary, Second Fidition, Auckland, 1995, pp. $284-5$.

118 James McNeish, Tavern in the Town, Wellington, 1957, pp. 10-11. Despite the title of his book, McNeish did not seem to favour the word 'tavern'.
} 
Australasia. ${ }^{119}$ Elsewhere a hotel is primarily an establishment that provides accommodation and food for tourists and travellers, possibly with a degree of comfort. ${ }^{12 n}$

The 1986 Working Party on Liquor noted that the liquor-accommodation link appeared to be based on the assumption 'that the provision of adequate hotel accommodation to meet the legitimate public demand requires that it be subsidised from the sale of liquor'. ${ }^{121}$ But although the link was intended to ensure that sufficient accommodation was provided for the travelling public, it appears to have had quite the opposite effect. Because licensed premises were to a large extent frozen in their 1881 location for much of the following century, licensed accommodation was likewise frozen in location. The obvious consequence was that some areas had a shortage of accommodation while others had a surfeit. In 1893 a MHR told parliament of hotel rooms provided under the 1881 Act lying 'empty and unused'. ${ }^{122}$ There is little evidence that the situation improved in subsequent decades. A Feilding magistrate who sat on several licensing boards told the 1945 Royal Commission on Licensing that '[i]n certain towns and townships you see hotels with unnecessarily large accommodation for the travelling public; accommodation that is never used - it is an economic waste. In other towns the accommodation is hopelessly inadequate. ${ }^{, 123}$ Much evidence of the ineffectiveness of the liquor-accommodation link was presented to the commission. A hotel inspector for the Automobile Association cited 43 cities, towns and other localities that he considered had inadequate accommodation for travellers. ${ }^{124}$ Yet evidence was also presented to the commission that many hotels rarely or never had guests. The chair of an Auckland licensing committee testified that he knew of six hotels that had 'not a single guest or lodger staying the whole year'. ${ }^{125}$ Several hotels run by the Campbell and Ehrenfried chain had just a handful of paying guests in the four years from 1935 to 1939 , and two had none at all. ${ }^{126}$ It was not just shortage of demand that led to empty hotels. Many publicans did not want the inconvenience of guests when

\footnotetext{
119 'lony Deverson and Graeme Kennedy (cds), The New Zealand Oxford Dictionary, Iuckland, 2005, p. 526. See also The Conise Oxford Dictionary, Oxford, 1991, p. 571 and The New Shorter Oxford English Dictionary, Oxford, 1993, p. 1268. The Shorter Oxford mentions Canada as also having this usage.

120 Sec cspecially The Nen Shorter Oxford English Dictionary, p. 1268.

121 Working Party on Liquor, p. 59.

122 NZPI 1893, volume 80, p. 388

123 PRCl., p. 6006.

124 Report RCL, pp. 133-4.

125 PRCl, p. 6524

126 PRCL, p. 4187.
} 
the limited demand was highly variable and all the profits from the business came from selling alcohol. It was therefore common for publicans to deter custom by claiming their hotel was full when all their rooms were vacant. ${ }^{127}$ Alternatively they used most of their accommodation to house staff and/or the occasional visiting friend or relative. ${ }^{128}$ Some licensees 'try to avoid their duty of taking in guests' scolded the commission. ${ }^{129}$ Furthermore the accommodation and meals provided in licensed hotels were often of a low standard. As the commission noted, requiring someone whose sole reason for being in business is to run a bar to also provide food and lodgings is not the most effective way to ensure quality. 'If the proprietor regards the hotel primarily as a place in which to sell beer instead of to provide accommodation, the accommodation is likely to suffer. ${ }^{, 130}$ As a result 'most of the hotel premises in New Zealand are much too old and have far too few modern facilities to be regarded as adequate for the convenience of the public'. ${ }^{131}$

The situation worsened after the war when price controls were imposed on room tariffs, making hotels even more reliant on the sale of liquor. ${ }^{132}$ The situation was exacerbated by the costs of extending the 40-hour week to the industry and full employment made hiring staff difficult due to ingrained attitudes towards service occupations. ${ }^{133}$ Regional surpluses and shortages of accommodation were still apparent in the 1960s, as was a persistent unwillingness on the part of publicans to meet their legal accommodation requirements. MacLauchlan reported that '[w]hen I was travelling around New Zealand as a journalist I was several times told by the publicans of dark and deserted hotels in country towns they were sorry they could not accept me as a guest because there were no spare rooms. ${ }^{134}$ In 1963 the Licensing Control Commission began exercising some of its new powers by inspecting the premises and records of every hotel in the country to assess its standard of accommodation and occupancy rate. By March 1969 the Commission found that over half of the country's 1104 hotels played 'an insignificant part or no part at

\footnotetext{
127 See, for example, PRCI , p. 7120.

128 PRCL, p. 7120 and Report RCL, p. 132.

129 Report RCl, p. 132. It was a legal obligation for publicans to accommodatc any traveller sceking accommodation unless the hotel was full.

130 Report RCL, p. 132. Of course the Commission's 'solution' was to try to compel the publican to treat the accommodation side of the business seriously.

131 Report RC1, p. 122. Modern facilities included rooms with hot and cold running water.

132 Margarct Meclure, The Wonder Country: Making New Zealand Tourism, Auckland, 2004, pp. 177, 181.

${ }^{133}$ McClurc, Wonder Country, p. 178.

${ }^{13}$ McLauchlan, Stoiy of Beer, p. 135
} 
all in the accommodation of travellers'. ${ }^{135}$ Even if hotels averaged just six bedrooms each, the minimum requirement in urban areas, this meant that some 3500 hotel beds were almost continuously empty. Yet during the same decade another government body, the Tourist and Publicity Department, lamented accommodation shortages. 'The main obstacle to the full utilisation of our tourist assets is still the shortage of suitable hotel accommodation at certain key points,' said its 1963 annual report. ${ }^{136}$ Later in the decade the department reported that the shortages had been alleviated in most places. Yet its reports made it clear that the improvements were entirely due to the spread of motels and other unlicensed accommodation, or to large hotels purpose-built for travellers such as the 610 bed Intercontinental Hotel that opened in Auckland in $1968 .{ }^{137}$ That and another large Auckland hotel, the South Pacific, were both built with the assistance of the government's Tourist Accommodation Development Scheme initiated in $1963 .{ }^{138}$ Accommodation subsidised by the sale of liquor played little or no part in the improved situation.

The LCC began to realise this fact by the mid-1960s. "The archaic philosophy that accommodation under all circumstances must be supported by a liquor licence is now due for examination,' said its 1965 annual report. ${ }^{139}$ In 1967 the Commission remarked on the spread of new tourist houses with no licence to sell liquor to the general public. We have not yet discovered how it is that tourist houses are successfully established to conduct the very business, that is accommodation, which hotels say they lose money on. ${ }^{140}$ The following year the LCC commented on the increasing number and popularity of motels, which were generally profitable despite having no liquor licence. 'Travellers simply prefer the privacy, spaciousness and amenities of a motel room and are becoming more and more disinclined to take a room in a hotel, particularly since ten o'clock closing, when they may have to put up with the hubbub from the bars below or nearby. ${ }^{, 141}$ The LCC had started its hotel inspections in 1963 as a supporter of the liquor-accommodation link. By 1968 it had dramatically changed its views. "The Commission has now gone far

\footnotetext{
135 LCC Annual Report, AJI IR 1969, II.3, p. 5.

136 Tourist and Publicity Department Innual Report, NJHR, 1963, H6.

137 Sce, for cxample, Tourist and Publicity Department Annual Report, AJHR 1967, H3, p. 6.

138 McClure, Wonder Conntry, pp. 212-3.

139) Tourist and Publicity Department Annual Report, AJI IR 1965, I I3, p. 8.

1+0 L'ourist and Publicity Department Annual Report, NJHR 1967, H3, p. 6. The Tourist-house licence is discussed below.

141 Tourist and Publicity Department Annual Report, AJI IR 1967, II3, p. 4.
} 
enough in the national review of the country's hotels to be able to show that the old conception - which is still clung to with limpet-like obstinacy and futility - that accommodation is necessarily linked with or dependent on revenue from the sale of liquor is an anachronistic absurdity. ${ }^{, 142}$

Over the years the government had moved to reduce at least some of the effects of this 'absurdity'. In 1948 it introduced a new type of licence, the Tourist-house Licence, to help deal with some of the frustrations of accommodation providers and their customers in dry tourist areas. ${ }^{143}$ These licences allowed hotels in recognised tourist destinations to serve liquor to their guests but not to the general public. The new licences were popular, for despite being strictly limited there were 48 'tourist hotels' by $1970 .{ }^{144}$ A further weakening of the entrenched liquor-accommodation link came when the 1960 Select Committee recommended that a levy be imposed on the numerous hotels that operated solely as 'beer houses' and provided no accommodation. The levies collected would accumulate in a fund that would be lent out to finance hotel renovations and new construction. $^{145}$ The government went further than proposed by the select committee when a 1961 Act divided hotel licenses into two classes - tavern and hotel licences. All hotel licences were made provisional from 30 June 1963 and publicans then had four years to decide whether they wanted their premises to operate as a hotel or tavern and apply to the LCC for a licence. ${ }^{146}$ There were initially few applications for the new tavern licences, for hoteliers objected to the three percent levy payable in lieu of providing accommodation. The Commission suspected that publican's dislike of the tavern licence was driven by the fact that providing accommodation (or at least pretending to do so) made it easy to avoid the early closing laws. ${ }^{147}$ This view seemed confirmed when there was a big increase in applications for tavern licences after ten o'clock closing returned in October 1967 , the deadline having by then been extended. ${ }^{148}$

\footnotetext{
142 LCC 1968 Annual Report, AJIIR 1968, II3, pp. 3-4.

143 I icensing Imendment . Ict, New Zealand Statutes 1948, Volume 2, p. 961.

$1+1$ licensing Control Commission Annual Report, AJHR 1970, H3, p. 11. The national number of Tourist-house Licences was initially limited to 25, Licensing Amendment Act, New Zealand Statutes 1948, volume 2, p. 932.

${ }^{145}$ Stace, pp. $4-5$.

14r Stace, especially pp. 149-155. The government declined to levy liquor outlets other than taverns.

${ }^{1+7}$ Stacc, p. 151.

$1+8$ The deadline continued to be extended and the last licence did not become unconditional until 1978, Stace, p. 159.
} 
Politicians criticised the liquor-accommodation link from time to time. 'I do not see why the beer drinker in particular should subsidise those people who are provided with accommodation,' Tamaki MP Bob Tizard told the house in $1960 .{ }^{149}$ Despite such criticisms and those of the LCC, the liquor-accommodation link stayed in place for another 30 years, primarily due to industry lobbying. The 1974 royal commission considered that the link was becoming outdated with the increasing number of new outlets, such as clubs and licensed restaurants, which did not have to pay the tavern levy. However it accepted industry arguments that providing unsubsidised accommodation was often uneconomic, and declined to recommend any change in the absence of a suitable and acceptable alternative'. ${ }^{150}$ In 1979 the Accommodation/Liquor Link Inquiry Committee repeated the royal commission's recommendation verbatim. ${ }^{151}$ The committee ignored evidence of an apparent inequity whereby a company that established a bar, but was not involved in the hotel business, was required to pay a three percent levy on tumover from which it derived no benefit. Instead the levy went into a fund known as the Hotel Investment Account that provided a source of cheap finance for the hotel industry. The Inquiry report revealed there was little in the way of targeting of this lending to ensure it helped relieve accommodation shortages. A submission from the Consumer Council portrayed the Hotel Investment Account as a slush fund used primarily to help the breweries increase the value of their assets. ${ }^{152}$ The Justice Department claimed the levy was used to prop up 'uneconomic and outdated units' rather than to provide new accommodation where it was needed. ${ }^{153}$ Despite the liquoraccommodation link having been in place for almost a century, the committee concluded that there was 'a serious shortage of high standard hotel accommodation'. ${ }^{154}$ But instead of taking this as evidence that the link did not appear to have worked to ensure the provision of adequate accommodation, the committee took this as evidence it should continue.

Although the 1986 Working Party on Liquor was a creature of its times, and thus illdisposed to accept measures that might undermine competition, it did not re-litigate the

\footnotetext{
(4) NZPD volume 325 , October 1960 , p. 3273.

150 Report of the Royal Commission on the Sale of Liquor 1974, p. 52.

151 Accommodation/ I iquor I ink Inquiry Committee, Report, Wellington, 1979, p. 52.

152 Accommodation/Liquor link Inquiry, p. 34. The breweries were significant owners of hotels.

153 Stacc, p. 172

$15+$ Accommodation/Liquor Link Inquiry, p. 51.
} 
arguments of the recent past regarding the liquor-accommodation link. Instead it took a different tack, recommending the abolition of the link on the grounds that the amount collected by the tavern levy was insufficient to finance the building of new hotels. ${ }^{155}$ While this argument was not entirely convincing, the fourth Labour government was inclined to accept reforms that would ensure a level playing field and therefore omitted any reference to accommodation from the 1989 Sale of Liquor Act. Much to the chagrin of publicans, the $\$ 100$ million accumulated in the Hotel Investment Fund disappeared into the government's Consolidated Fund. ${ }^{156}$ There seems little evidence that the abolition of the liquor-accommodation link in 1989 inhibited the growth of tourist accommodation in the $1990 \mathrm{~s}^{157}$

The liquor-accommodation link was possibly the only restriction relating to alcohol that was not supported by prohibitionists. They objected to the assumption, often stated explicitly, that providing accommodation was unprofitable and needed to be subsidised by liquor sales. ${ }^{158}$ The industry, on the other hand, vigorously argued for the retention of the alcohol-accommodation link whenever it was questioned. ${ }^{159}$ As the LCC noted in the 1960 s, the link enabled publicans to trade after hours due to the legal exemptions for hotel guests. ${ }^{160}$ More importantly, the liquor-accommodation link helped protect existing players in the industry from competition. Bar owners, who were often overcapitalised through having to provide unnecessary accommodation, would be disadvantaged if new entrants did not have to make the same capital investment. But equally important in keeping out competition was the 'need' test that had been in the legislation since the 1880s. For example the 1962 Sale of Liquor Act required the LCC to take into account the impact that any new licences might have on the provision of accommodation for the travelling public. ${ }^{161}$ Publicans regularly and successfully argued that this requirement meant that their liquor sales business should be protected from competition so that it

\footnotetext{
155 Working Party on I iquor, pp. 59-60.

156 Brien, 100 Years of Hospitality, p. 123.

157 For example, Mclure, The Wonder Country, does not mention any issues of accommodation shortages in her chapter on the 1990s, although this is a common theme in her coverage of other decades.

158 Dash, No-L kiense Handbook, p. 84. The Alliance counsel to the 1945 royal commission argued that the law should divorce accommodation and bars, PRCl, p. 1965.

159 See, for example, New 7ealand Liquor Industry Council, Submission to the Royal Commission on Liquor, 1974, part 2, pp. 14-19.

160 Stace, p. 155, 162. 'This point is discussed in more detail in the chapter on closing hours.

161 Sale of Iiquor Act, New Zealand Statutes 1962, volume 2, p. 1143. See also Southwick et al, The Liquor Laws of New Zealand, pp. 20-1.
} 
could continue to subsidise accommodation. This argument frustrated the LCC, particularly when it was clear that the hotel in question was doing little to provide accommodation to travellers. ${ }^{162}$ The Hotel Association tried to use the accommodation argument to oppose the licensing of restaurants and was supported in this by the Minister of Tourism. ${ }^{163}$

The alcohol-accommodation link seemed to have made things worse rather than better in terms of the provision of adequate quality accommodation for travellers. In addition, requiring those selling alcohol for on-site consumption to either provide sleeping accommodation or pay a levy on turnover militated against the small-scale bars often desired by the public. As the Justice Department noted in 1980, it would make more sense to treat the accommodation issue separately and allow the liquor laws cto develop more in accordance with social trends and needs. ${ }^{164}$

\section{Dry Districts}

So far this chapter has dealt primarily with the historical obstacles to obtaining new liquor licenses, which helped perpetuate problems such as overcrowded bars. However there were also significant parts of the country in which liquor sales were prohibited altogether, generally called no-licence or 'dry' districts. In 1884 the government imposed prohibition in the King Country because of Maori pressure. ${ }^{165}$ Between 1894 and 1908, 12 of the 76 European electorates voted to ban all liquor sales. The status of the King Country as a no-licence district was formalised in 1909 except that residents were denied any means to restore licences by way of a poll. ${ }^{160}$ As outlined in Chapter 3, over time the number of no-licence districts further increased because of the congruence between the borders of licensing districts and those of the regularly-changing general electorates. By the time the government started to remove some of these legislative anomalies in 1945 some 18

\footnotetext{
162 'The Commission outlined some of these frustrations in its 1967 Innual Report, AJHR 1967, H3, pp. 6-9.

${ }_{163}$ NZPD 1960 , volume 325 , p. 3262.

tint Quoted by Stace, p. 172.

165 The King Country cut across several electorates and generally had a population equivalent to roughly two licensing districts, figures calculated from Report RCl, pp. 219-20. There was also provision in the Licensing Amendment Act 1910 for Native Prohibition Districts, although only one of these banned liquor supply to Maori for a brief period from 1911 to 1922 , Report RCL, p. 36.

166 King-country Licenses Act, New Zealand Statutes 1909, p. 266.
} 
percent of the population - and over 40 percent of the residents of Auckland and Wellington - lived in dry districts. ${ }^{167}$

In 1945 the Justice Department and some police witnesses advocated the abolition of dry districts on the grounds that the law was difficult to enforce and interfered with the sensible distribution of liquor outlets. ${ }^{16}$ However this was a minority view and the Royal Commission on Licensing did not recommend any changes other than provisions for trust control following restoration of licences. ${ }^{169}$ By the time the Royal Commission on the Sale of Liquor reported in 1974, all the provincial dry districts had voted to restore licences and no-licence was a phenomenon confined solely to suburban Auckland and Wellington. The Justice Department again argued for the elimination of dry districts or at least the reduction of the required three-fifths restoration majority to a bare majority. The royal commission dismissed these proposals for reasons that included the novel grounds that 'it would seem unfair to change the rules before the contest had been completed.. " None of the suburban dry districts were in any hurry to go wet, and by the time the Working Party on Liquor produced its report in 1986 there were still four suburban nolicence districts and four special areas. ${ }^{171}$ The desire of suburban residents to keep pubs out of their neighbourhoods is not hard to fathom. The modern term for the phenomenon is the NIMBY ('not in my back yard') syndrome. The 1945 Royal Commission recognised this fact in its report when it noted that voters in urban nolicence districts were substantially more likely to support no-licence than to support national prohibition. The Commission surmised 'that many desire themselves a drink in the city area, but have no desire to have liquor sold in their residential area'. ${ }^{172}$ Witnesses had told the Commission as much, a view reflected by a Wellington MP who told parliament in 1946; 'I would not like an hotel in my own home suburb of Hataitai. ${ }^{173}$ The Commission clearly sympathised with the position of those in dry suburbs but the 1986 Working Party was more critical in its assessment of the situation:

\footnotetext{
167 Figures calculated from Report RCl, pp. 22, 197-8.

168 PRCL, Pp. 109, 335, 5239 and 7768-9.

${ }^{169}$ Report RCL, p. 338.

${ }^{170}$ Royal Commission on the Sale of I iquor 1974, p. 151.

171 Working Party on Liquor, pp. 85, 89.

172 Report RCL, p. 211.

173 NZPD 1946 vol. 294, p. 708.
} 
The obvious explanation for the strong support given to Local No-Licence is that people do not object to the existence of hotels and taverns but to the presence of these establishments in the immediate neighbourhood. They would prefer any adverse effect on the environment to fall elsewhere. The answer to any reasonable concern of this kind lies in establishing a link between the licensing and the town planning processes. The planning laws were developed to provide community input into any planned development, from service stations to shopping malls to rubbish tips. People in "wet" areas presumably have the same reaction to taverns as people in "dry" areas. They should all be able to make their wishes known through the same process. ${ }^{174}$

In other words the Working Party was advocating a level playing field under which everyone who might object to a liquor outlet being located in their neighbourhood was subject to the same rules. Their report described the remaining no-licence districts as 'an unwarranted privilege' that pushed problems onto surrounding districts where residents did not have the same rights. It recommended the abolition of dry areas as they allegedly encouraged drinking and driving and the erection of large taverns on their borders. ${ }^{175}$ The ensuing parliamentary select committee was bombarded with submissions from the residents of no-licence districts demanding to retain their traditional ability to keep out pubs, and recommended no action. ${ }^{176}$ Instead, as outlined in Chapter 3, the government acted more subtly by abolishing three of the four special areas in 1989 and lowering the threshold for restoration of licences to 50 percent in 1990. The last dry areas went wet in 1999.

In 1905 dry districts were almost exclusively towns and semi-rural districts in the far south, heavily influenced by the puritanism of their Scottish Presbyterian heritage. But by the early 1960 s dry districts had become confined to the suburbs of Auckland and Wellington, where middle-class and aspirant voters used an inherited privilege to protect their property values at the expense of the residents of surrounding areas. It is unlikely that dry suburban districts added greatly to the maldistribution problem until the end of six o'clock closing in 1967 made suburban taverns viable. But by the 1970s the perpetuation of dry districts did much to contribute to the phenomenon of 'booze barns'.

\footnotetext{
174 Working Party on Liquor, p. 86.

175 Working Party on Liquer, pp. 65, 85 .

176 Report of the Committee on the Sale of Liquor Bill 1989, p. 64.
} 


\section{Booze Barns and Beyond}

Many of those who voted for ten o'clock closing in 1967 appeared to have fondly imagined that the change would herald a new era of English-style local pubs or Europeanstyle cafés providing a venue for friends and neighbours to meet and socialise. In the words of a 1974 Justice Department report, "[t]he concept of the "community tavern" is often put forward, sometimes with wistful mention of the English "local". ${ }^{177}$ Those who held such hopes were to be sadly disappointed. The extended hours may have made it desirable for pubs to be located near where people lived rather than just near where they worked, but the licensing rules made it very difficult for this to happen. As a result, suburban taverns were few in number but tended to be large in size, often surrounded by massive car parks. The era of the booze barn had arrived.

A perusal of the LCC files gives an indication of the size of some of the taverns erected in the late 1960s and early 1970s. The main bar at the Bush Inn in Christchurch, with a floor area of 6500 square feet, was easily large enough to stage an NBA basketball game. ${ }^{178}$ It was more than six times the size of a Palmerston North bar that the LCC approved in 1973 as a venue for regular dances. ${ }^{179}$ In 1968 New Zealand Breweries was granted approval for a huge tavern on 14 acres of land at Mangere Bridge in Auckland. The four bars totalled 15,800 square feet excluding the service area, enough to comfortably accommodate three NBA basketball courts. ${ }^{180}$ Although licensing trusts were supposedly established to be more innovative in their approach to licensing issues, they were subject to similar objection and poll provisions as private companies and were equally susceptible to the booze barn trend. ${ }^{181}$ The Johnsonville Licensing Trust built bars of 5000 and 8000 square feet. ${ }^{182}$ In the 1960 s the Invercargill Licensing Trust purchased six acres of land

177 Department of Justice submission 18, p. 31. The submissions are held at Irchives New 7ealand, COM 21/8, and are hereafter referred to by their submission number.

178 I icensing Control Commission file 115a, J.CC/CIN, Archives New 7.ealand A.ADM 678, 1971. Bar dimensions as recorded in the LCC files appear to include the serving area unless otherwise stated. The official dimensions of an NB. I basketball court are $94 \times 50$ feet making 4700 square feet. In international basketball court as used in the Olympic (ames is slightly smaller than that used in the NBA, 'USA Basketball', http://www usabasketball.com/rules/tules.html.

179 Licensing Control Commission file 58a, LCC/MLAN, Archives Ncw Zealand AADM 678, 1973. The bar in question was the lounge bar at the Taverners $1 \mathrm{rms}$, which was 1024 square feet including a 300 square foot dance floor.

${ }^{180}$ I icensing Control Commission file 13a, J.CC/. NUC, Archives New Zealand A.MDM 678, 1968. The total area of the t tavern including bottle store, toilets and storage was 18,300 square feet.

181 Southwick et al, The Liquor Laws of New Zealand, pp. 372-3.

182 Submissions to the Royal Commission on the Sale of Jiquor, Archives New Zealand, COM 21/8, submission number 205. Even the smaller of these bars was larger than a basketball court. 
for the Newfield Tavern, a cavernous barn that opened in $1970 .{ }^{18.3}$ The main bar in the Northside Seven Tavern in Oamaru had an area of 5600 square feet. ${ }^{184}$

Although booze barns were large, they were also frequently crowded as the number of pubs in the country remained steady despite a growing population and an increasing demand for liquor. They were often the only suburban drinking establishments for many kilometres and their large car parks were convenient for patrons. They were criticised for encouraging violence and drinking and driving. ${ }^{185}$ In Janurary 1974 the Inquiry television programme investigated why booze barns had become so common. ${ }^{186}$ The programme looked at examples such as the Trident Tavern in Onehunga, which accommodated 500 people on an average night and was allegedly a regular source of trouble. According to presenter Joe Cote, market research by the breweries led them to try to establish facilities in new housing areas where there was big demand, 'and because they can only get one licence they can put in just one tavern and it's invariably big. ${ }^{187}$ The programme also highlighted some of the problems caused by the existence of suburban dry districts. Herne Bay residents opposed a tavern because they feared it would attract large numbers of people from the neighbouring dry stronghold of Grey Lynn. Later in the year a New Zealand Listener article reported on the difficulties posed by the local objection provisions, which slowed down or stopped the erection of suburban pubs. It gave the example of West Auckland where the Licensing Control Commission had recommended the simultaneous opening of 24 community taverns but only one had actually been approved. $^{188}$

Numerous submissions to the 1974 Royal Commission condemned booze barns and called for the establishment of small local taverns and cafes. ${ }^{189}$ 'Having spent five pleasant years in England, I am convinced that the availability of a local pub is desirable... in that it

183 Clive J ind, Pubs, Pints and People; 50 Years of the Invercargill Licensing Trust, Invercargill, 1994, pp. 90, 95, 97-8. I ind's book includes exterior and internal photographs of the Newfield Tavern, showing its huge size, pp. 94-5.

184 ] icensing Control Commission file 115a, I.CC/C.IN, Irchives New Zealand IIIDM 678, 1971.

185 Examples can be found in Submissions to the Royal Commission on the Sale of Liquor numbers 24, 131, 140, 193 , 194, 171, 195, 222; and Ministerial Committee into Violence, Report, Wellington, 1987, p. 54-5.

186 A transcript of the programme was published in the New Zealand Listener, 19 January 1974, pp. 14-15.

${ }^{187}$ Inquiry transcript, Nen Zealand L istener, 19 January 1974, pp. 14-15.

188 New Zealand Listener, 16 November 1974, pp. 14-15.

189. There were 27 submissions from organisations and individuals wanting community taverns and/or complaining about booze barns - numbers, 13, 14, 16, 18, 24, 43, 44, 52, 53, 79, 82, 128, 131, 132, 140,141, 159, 191, 193, 194, 195, 202, 205, 206, 213, 222, 225, Archives New Zealand, COM 21/8. 
offers a focus for the social life of the surrounding community, a focus sadly lacking in our bleak suburbs,' was the view put in a fairly typical submission. ${ }^{190}$ Perhaps the most damning criticisms of the existing licensing system came from the Department of Justice. It condemned the 'plethora of polls and rights of objection' which had militated against the rational distribution of hotels and taverns. Why do we insist on subjecting the existence of a community tavern to a poll when we do not think of doing so for TAB premises or rubbish tips or noisy and offensive trades? In these matters we rely on good town planning rules. ${ }^{191}$ The department pointed out that voters almost invariably reject proposals for new taverns, perhaps influenced by 'the sort of premises he has seen - in extreme cases an enormous barn surrounded by a desert of asphalt'. As a result 'the rejection of additional outlets relatively close to where people live encourages and perpetuates this very type of premises. ${ }^{192}$ The department's proposed solution included radically simplifying the licensing system by reducing the number of different types of licence from 24 or so to just four. ${ }^{193}$ It argued that numerous tightly defined licences led to a proliferation of groups with vested interests intent on keeping out competitors. ${ }^{194}$

The proposals were opposed by the industry, which no doubt realised that a simplified licensing system would make it easier for new players to open outlets to compete with established interests. ${ }^{145}$ The Royal Commission not only rejected the department's proposals but also recommended two additional types of licence. ${ }^{196}$ While the commission gave support to the idea of community taverns, an idea that the LCC had been pushing since the late $1960 \mathrm{~s}$, it recommended no legislative changes that would facilitate their establishment. ${ }^{197}$ However the commission did make other recommendations that eventually assisted the demise of booze barns by helping increase the number of liquor outlets. The number of outlets had already been increasing gradually since the early 1950 s with new club licences, the licensing of restaurants and, from 1971, the issuing of 'cabaret' licences that allowed alcohol sales with food and entertainment

\footnotetext{
190 Submission to the Royal Commission on the Sale of Liquor, Archives New Zealand, COM 21/8, number 11.

191 Justice Department submission to the Royal Commission on the Sale of Liquor, p. 31.

192 Justice Department submission, p. 32.

193 Justice Department submission, p. 40. For the number of licence types see N L Liquor Industry Council, Submission to the Royal Commission on Liquor, 1974, section 2, p. 3.

194 Justice Department submission, p. 25.

195 Royal Commission on the Sale of Liquor, pp. 38-9.

196 Royal Commission on the Salc of Liquor, pp. 299, 313.

197 Stace, pp. 250-1.
} 
between six and $11.30 \mathrm{pm}$. However the number of licensed restaurants grew slowly and there was little demand for cabaret licences, with just two issued in the first year and only 28 in place by $1979 .^{198}$ Then in 1976 two legislative changes based on recommendations from the 1974 commission led to a big increase in outlet numbers. All sports clubs were able to apply for 'general ancillary' licences, later renamed club licences, and restaurants could be issued with BYO permits that enabled customers to bring their own alcohol for on-premises consumption. ${ }^{199}$ Licensed clubs quickly become the most common form of liquor outlet and by 1987 their numbers had increased from 386 to nearly $2500 .^{200}$ The new BYO permits also proved popular, with over 1300 in place by $1987 .^{201}$ Restaurant licences were made easier to obtain and these ballooned in number from 198 to 760 in the decade after $1977 .^{212}$ The overall result of the changes was that the number of licensed liquor outlets per capita increased by 150 percent between 1977 and 1987, as shown by Figure 4.2.

As will be discussed in Chapter 6 there was some dispute in the 1980s about the extent to which the legislative changes had resulted in a genuine increase in availability. Because many sports clubs had been illegally selling liquor long before the changes, the actual extent of the increase cannot be accurately quantified. All the same, because of the licensing of sports clubs and the big increase in licensed and BYO restaurants, the pub became a less common venue for an evening out. Some booze barns were partitioned into smaller bars and dining areas to attract back custom. ${ }^{213}$ The LCC somewhat belatedly put a size limit on new taverns in 1981. ${ }^{214}$ But despite their decline, booze barns were still causing concern in the $1980 \mathrm{~s}$. The police report to the 1987 ministerial inquiry into violence noted that, with large numbers of patrons, a small incident could spark a brawl; restrictions on age and sobriety were difficult to enforce; and attempts at enforcement occasionally resulted in confrontations with groups of patrons 'which far outweigh the

\footnotetext{
198 Stace, p. 239 and LLC 1980 Annual Report, AJHR 1980, E8, p. 7. From its Annual Reports it is clear the LCC was very conservative in issuing cabaret licenecs.

199 Sale of Liquor Amendment Act, New Zealand Statutes 1976, pp. 654-5 and pp. 681-3. BYO permits could be issued from December 1976 and ancillary licences from Ipril 1977.

200 LCC. Annual Report, AJHR, L8, 1988.

201 LCC Annual Reports, AJHR 1981 and 1988, E8.

202 LCC Innual Reports, AJI IR 1981 and 1988, E8. These were actually 'food and entertainment' licences, so the figures include a small number of cabarets and nightelubs.

203 Working Party on Liquor, p. 33.

${ }^{20+}$ LCCC Annual Report, AJI IR 1987, E8, p. 3.
} 
gravity of the original offence or incident ${ }^{205}$ The committee was convinced that booze barns were undesirable and advocated the building of small taverns. But at the same time it opposed any increase in the number of liquor outlets. ${ }^{206}$

\section{Figure 4.2: Number of Licensed Liquor Outlets per 1000 People, 1960-2004}

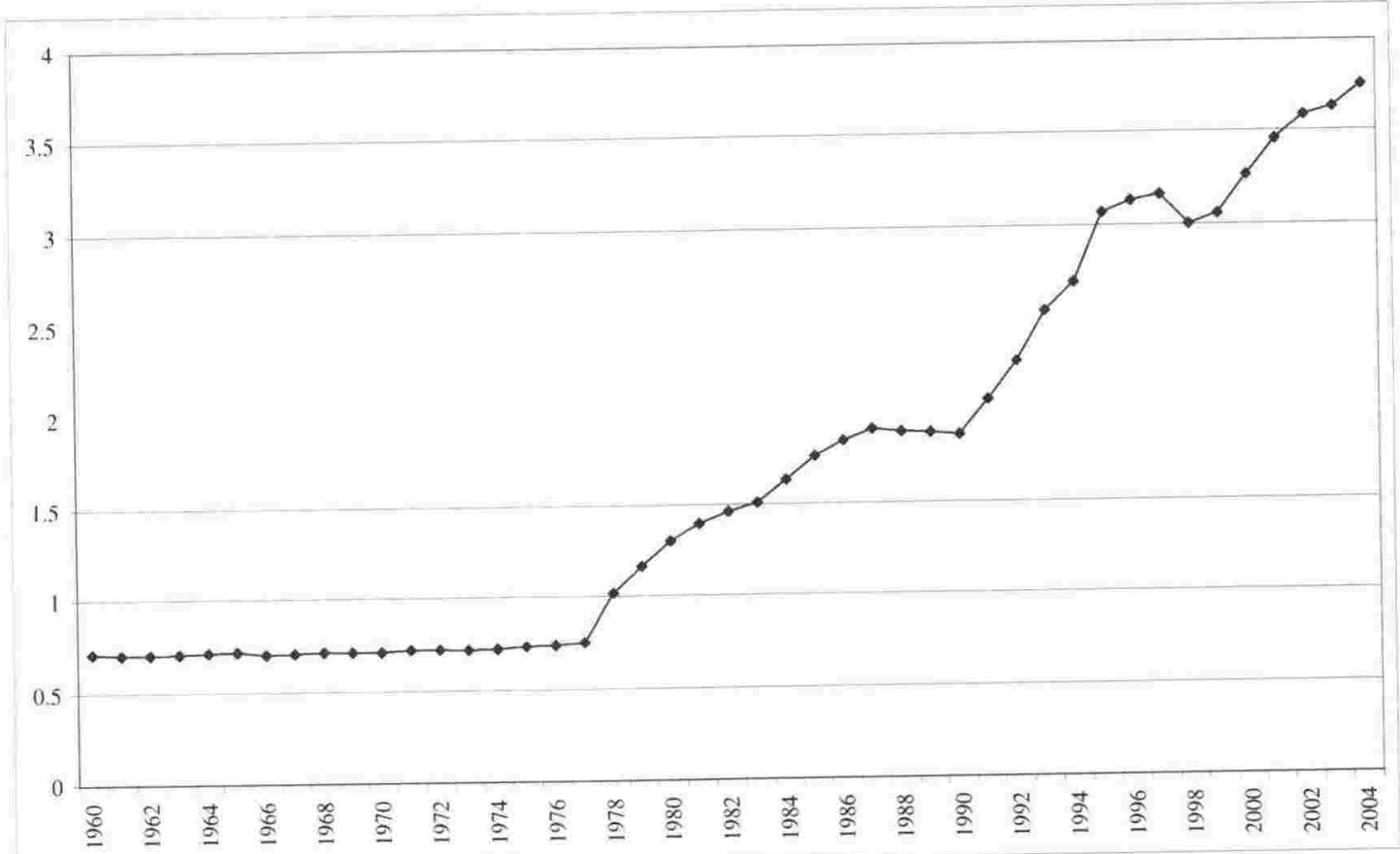

Source: J.M. Valentine, Alcohol and Public Policy: Working Paper for the Prevention Review, Wellington, 1982; LCC annual reports 1981-1989 and Liquor Licensing Authority. ${ }^{207}$

In 1986 the Working Party on Liquor had already pointed out the contradiction inherent in such a position; if liquor outlets were to be small and uncrowded then obviously there must be more of them. The working party rejected the availability theory, pointing to the apparently big increase in liquor outlets since 1977 with no increase in alcohol consumption. ${ }^{218}$ It produced a draft Sale of Liquor Bill that dispensed with most of the provisions that limited the number of liquor outlets in New Zealand. It proposed a radically simplified licensing system whereby there were only four types of liquor licence

\footnotetext{
205 Quoted in Ministerial Committee of Inquiry into Vislence, p. 54.

206 Ministerial Committee of Inquiry into Violence, pp. 53, 55.

207 'The population figures used to calculate the rates are from NZOYB 1990, p. 128 and the Statistics New Zealand web site. Licensing figures for the years 1991 and 1995 to 2004 were provided by the Liquor Licensing Authority (LLA). Figures for the years 1992 to 1994 were cstimated from the LLA Annual Reports, AJHR L8. The estimates involved subtracting license cancellations from new licenses approved so do not include licenses voluntarily forfeited and will therefore overstate total outlet numbers slightly in those years. The figure for 1990 is from the LLA Annual Report of that year. Most figures are as at 31 March but more recent figures are for a variety of dates depending on when the L.t produces its figurcs.
}

208 Working Party on Liquor, pp. 34-5. 
rather than the 29 or so then in existence. ${ }^{201}$ The 'need' test that protected pubs from competition was to be dispensed with, as were the special polling provisions that prevented the building of new hotels and taverns. ${ }^{210}$ The remaining dry districts were to be abolished, as recommended by a select committee back in $1960 .^{211}$ Other barriers to competition such as the alcohol-accommodation link were also to go. These barriers included archaic provisions that required pubs to serve anyone not obviously drunk, and a legal requirement for a bar to stay open even if it had no customers. These restrictions made it difficult for small-scale bars to be profitable and undoubtedly contributed to the booze-barn phenomenon. As the working party pointed out, it was not clear how these requirements did anything to help limit alcohol abuse. ${ }^{212}$

The parliamentary select committee that reported on the draft bill accepted all these proposed changes except the abolition of dry districts. ${ }^{213}$ It rejected the availability thesis despite large numbers of submissions claiming that more liquor outlets would mean more drinking. ${ }^{214}$ Although some of these submissions came from medical professionals the committee considered their evidence to be highly selective or ambiguous. Other submissions against any removal of restrictions predictably came from the Alliance, church groups and the industry. ${ }^{215}$ The Hotel Association ran a campaign against the changes, fearful of the effects of increased competition on their business. Their fears proved well founded. The removal of most of the barriers to competition in 1989 accelerated the process that had begun a decade earlier of old-style pubs being renovated or demolished. ${ }^{216}$

With the passing of the Sale of Liquor Act 1989 came perhaps the most radical increase in liquor availability ever implemented in New Zealand. The result, as can be seen from Figure 4.2, was a 64 percent increase in the per capita number of licensed liquor outlets

\footnotetext{
209 Working Party on Liquor, p. 49.

210 Working Party on Liquor, pp. 57-8, 87-9.

211 Working Party on I iquor, p. 65.

212 Working Party on liquor, pp. 61-2.

213 Report of the Committce on the Salc of liquor Bill, pp. 46.

214 Report of the Committee on the Sale of Liquor Bill, p. 25.

215 Report of the Committee on the Sale of Liquor Bill, pp. $22-25$.

216 In Wellington, for example, almost every old-style pub has either closed down or been totally renovated since the early 1980s. In 1974, Pat Lawlor catalogued 37 hotels and taverns in or near central Wellington, Pat Lawlor, Old Wellington Hotels: Some History, Personalities and Anedotes, Wellington, 1974. Thirty years later just nine of these remained as bars, the rest having been demolished or renovated for other uses.
} 
between 1990 and 1995 and a doubling in outlets per capita by 2004. The increase in outlet numbers was driven by two major reforms. One was the removal of the needs test for new liquor outlets that helped protect existing providers from competition. This made it much easier for new bars and cafes to open in competition with the hotels and taverns that were previously protected by legislation. The other reform was the licensing of supermarkets and grocery stores to sell wine six days per week. Only supermarkets in dry and licensing trust areas were prohibited from applying for a licence. ${ }^{217}$ Since 1990 public taste has played an increasingly prominent role in the type of drinking facilities provided. Drinking establishments have come and gone, often with perplexing rapidity. A oncepopular bar may within a few years fall victim to fickle public tastes, often to be replaced in short order by a café, bar or restaurant on the same site.

\section{Conclusion}

Many seem to have hoped that, with the end of early closing in 1967, the English-style local would become established in New Zealand towns and cities. But the chance that this might happen was strangled in the colonial era thanks to the rigid application of the availability theory - that more liquor outlets meant more drinking - and the requirement that public houses be large enough to also provide accommodation for travellers. New outlets were halted and the distribution of hotels was largely frozen at its 1880s configuration, closures aside, until the 1960s. As the Justice Department noted in 1939, it was as if the framers of the law had assumed that the population of the country would remain forever static. The protecting of existing providers from competition mitigated against decent hotel standards, for publicans had no commercial incentive to make improvements. The attempts of the 1945 Royal Commission to grapple with the problems led it to unhelpfully propose the nationalisation of the breweries - heavily influenced, it has been argued, by Justice undersecretary Berkeley Dallard. More constructively, the royal commission proposed a new national body to try to redistribute licences and enforce improved standards, although the new Licensing Control Commission proved largely ineffective until it was given increased powers in the 1960s.

The problems caused by the maldistribution of hotels were exacerbated by regular polls that prevented the establishment of new pubs. Even after restrictions on new outlets were lifted in the 1960s, the ideology that liquor had a unique status perpetuated objection

217 Sale of Liquor Act, New Zealand Statutes 1989, volume 2, pp. 1258, 1267-9, 1277, 1355-9. 
and poll provisions that made the erection of new hotels and taverns extremely difficult. In significant parts of suburban Auckland and Wellington hotels and bottle stores were banned altogether until 1999 because of the entrenchment of dry areas. Competition was also limited by the mistaken notion, promulgated by the industry and opposed by prohibitionists, that the free market was incapable of providing accommodation for travellers unless that accommodation was subsidised by liquor sales. The liquoraccommodation link persisted for over a century due to its support by the industry, despite not the slightest piece of evidence that it did anything to improve the country's stock of accommodation for travellers. Instead, it enabled publicans to trade outside legal hours and helped them keep out competition through the 'need' test, which protected their liquor business on the specious basis that competition would harm the provision of accommodation.

In 1989 the government removed most of the barriers to competition among liquor outlets. According to the availability theory this reform should have resulted in a large increase in drinking and related problems. Chapter 6 will examine whether or not it did so. 


\section{Chapter 5}

\section{THE SIX O'CLOCK SWILL}

The hours during which a hotel may serve drinks are apparently fixed on the theory that a man should drink in working hours but abstain strictly when he is at leisure. ${ }^{1}$

The Brewery executive quoted above was of course referring to the institution popularly known as six o'clock closing. While he was being ironic, there is a strand of truth to his statement. As was seen in earlier chapters, a major purpose of restricting the availability of alcohol was to remove temptation, and it is during his hours of leisure that a man (for it was male behaviour that was the prime target of restrictive measures) was seen as being most vulnerable to temptation. New Zealand was the only country in the world to prohibit liquor sales after six pm on a national basis. Six o'clock closing remained in place for 50 years, resulting in what its detractors dubbed 'the six o'clock swill'. This chapter will outline why six o'clock closing was introduced and discuss some of its effects. It will try to explain why early closing was endorsed by a referendum in 1949 but rejected almost as emphatically by a further referendum 18 years later. The influence of restrictionism was an important factor in instituting early closing, which was introduced during the antialcohol hysteria of World War One. However the influence of what has been dubbed the 'cult of domesticity' was subsequently an important factor in keeping it in place. It came to be widely believed that men (and possibly some women) would not return home for dinner without the legal compulsion provided by evening bar closures.

Until the First World War prohibitionists and advocates of availability restrictions concentrated primarily on trying to restrict the number of liquor outlets rather than on reducing hotel hours. However the issue of opening hours did not totally escape the attention of restrictionists. 'Give the people the most abundant opportunities for drinking and they will avail themselves of those opportunities,' a member told the House of Representatives in $1880 .^{2}$ Most provinces banned Sunday liquor sales, a restriction never

\footnotetext{
1 Dominion Breweries Chairman Jeonard Stevens testifying to the 1945 Royal Commission on Iicensing, PRCT, p. 6685.

${ }^{2}$ NZPD 1880, vol 35, p. 205.
} 
imposed in England. ${ }^{3}$ Petitioners seeking a similar restriction throughout the colony were successful when an 1881 Act imposed nation-wide Sunday closing. ${ }^{4}$ In addition, bars could open after ten pm only with a special midnight-closing permit. ${ }^{5}$ In 1893 late closing was cut back to $11 \mathrm{pm}$ and late closing permits were abolished altogether in $1910{ }^{6}$

The reduction in New Zealand hotel opening hours in the late-nineteenth and early twentieth centuries can perhaps be seen in the context of an increased demarcation between work and leisure. Males and unmarried women in particular were increasingly employed in urban or small-town settings where they were required to work regular hours. During the 1890 s the working hours of women and children in factories, shops and offices were limited by legislation. ${ }^{7}$ Males also enjoyed shortened work hours even before the Arbitration Court began setting standard working hours for unionised urban males after 1900. In addition, 'many forms of work came to be seen as drudgery, while fun, pleasure and play were thought to require leisure." Heron noted in relation to late nineteenth century Canada that because of the increased work-leisure divide, battles over access to alcohol were 'at the centre of broad cultural confrontations over how to spend leisure time and money?" The saloon or the pub competed with more worthy pursuits for workers' precious leisure hours. ${ }^{11}$ Among those attempting to influence the outcome of this competition were those in the burgeoning social purity movement who espoused causes such as prohibition and restricting impious activities on the Sabbath. ${ }^{11}$ In England an association established in the 1860s advocated the closure of public houses on Sundays 'for the special reason that on that day the working classes are not employed in their ordinary labours, and they are therefore peculiarly exposed to temptations.' ${ }^{12}$ New Zealand sabbatarians succeeded in banning Sunday liquor sales in 1881, thereby hoping to

${ }^{3}$ N7PD 1880, volume 35 , p. 109.

+ Sec, for example 'Schedule of Petitions', Journal of the House of Representatives 1877, numbers 122, $171,219$.

5 Licensing Ict, NZ Statutes 1881, p. 159.

${ }^{6}$ Southwick ct al, The Liquor L ans of New Zealand, p. 3.

7 Martin, Holding the Balance, pp. 40, 50-51.

8 Barbara Brookes, Frik Olssen and Iimma Beer, 'Spare 'Time? I eisure, Gender and Modernity', in Barbara Brookes, Annabel Cooper and Robin Law, eds., Sites of Gender: Women, Men and Modernity in Southern Dunedin 1890-1939, Auckland, 2003, pp. 151-2.

${ }^{9}$ Heron, Booze, p. 11, 83-4.

10 Ileron, Booze, Pp. 221-2.

11 Gary Cross, A Social History of Leisure Since 1600, Philadelphia, 1990, pp. 88-101.

12 A member of the Central Association for Stopping the Sale of Intoxicating Jiquors on Sundays reported in the Manchester Guardian, 15 October 1868, quoted by John Wigley, The Rise of the Victorian Sunday, Manchester, 1980, p. 172. 
remove the temptations of drink at a time when Sunday was for many workers the only day of leisure.

The imposition of universal ten o'clock closing after 1910 may well have been the last reduction in hours if it had not been for the First World War. As discussed in Chapter 2, the early twentieth century saw the rise of the ideology of national efficiency which was further boosted by the exigencies of large scale warfare. Alcohol became a particular target of national efficiency campaigners. In Britain there was a 'national hysteria on drink', boosted by inflammatory pronouncements by Prime Minister Lloyd George. Pubs were required to close in the afternoons and after ten $\mathrm{pm}$ in most parts of Britain almost from the outset of the war. ${ }^{1.3}$ Even in France the sale of absinthe was temporarily curtailed. $^{14}$ Alcohol sales were banned completely in most Canadian provinces and in many American states. ${ }^{15}$ Four Australian states introduced six o'clock closing in $1916 .{ }^{16}$ In New Zealand too there were frequent calls for further restrictions on drink, including early closing of bars, in the interests of greater wartime economic efficiency. The reputed advantages of early closing included increased productivity through less drunkenness; shipping space saved by the elimination of unnecessary cargo; and less wastage of scarce sugar supplies. ${ }^{17}$ Soldiers would drink less and be less likely to catch venereal diseases, it was claimed. ${ }^{18}$ Large petitions on six o'clock closing were presented to parliament in 1915 and 1916 and public meetings regularly endorsed early closing in the interests of national efficiency. ${ }^{19}$ Advocates of six o'clock closing frequently noted that other governments had restricted alcohol sales and that New Zealand was lagging behind. ${ }^{20}$ Many businessmen supported further restrictions and even prohibition, with some eventually forming National Efficiency Leagues in support of the cause. ${ }^{21}$ Prohibitionists joined the rhetoric, with the Alliance advocating early closing because of the 'continued need for

\footnotetext{
13 Greenaway, Drinke and British Polifis, pp. 97-107.

14 Heron, Booze, p. 377.

15 Complete prohibition in the United States, while ostensibly a measure to aid wartime economic efficiency, did not come into effect until 1919 due to the slow workings of the political process. Heron, Booze, pp. 178-9 outlines the influence of wartime national efficiency campaigns in Canada on the liquor debate.

${ }^{16}$ Lewis, A Rum State, p. 62.

17 Steven Tarly, 'The Six O'clock Closing Debate', Postgraduate Diploma in History Research Essay, University of Otago, 1991, pp. 23-26.

18 NZPD 1916, volume 177 , p. 278-9.

19 V anguard, 19 May 1917, no. 700, pp. 4, 10 and Cocker and Murray, p. 116.

20 Farly, "The Six O'clock Closing Debate', pp. 20-21.

21 Cocker and Murray, pp. 127-129, refer to the league in the singular while other sources use the plural form.
} 
economy and efficiency.22 The wording of its 1916 petition called for wartime early closing at a time when the 'moral physical and financial power of the nation should be at its highest'. ${ }^{23}$ In this environment it is unsurprising that when the government established a National Efficiency Board in 1917 it quickly became involved in the liquor issue.

Despite being presented with substantial petitions, parliament was disinclined to further meddle in licensing issues and voted down an early closing bill in 1916. ${ }^{24}$ The Government's main concessions to the prohibitionists were to outlaw the shouting of drinks and prohibiting women from bars after six pm. ${ }^{25}$ By late 1916 some temperance supporters doubted the worth of pursuing the early closing campaign, a feeling that remained the following year according to reports of regional meetings on early closing. ${ }^{26}$ But supporters of six o'clock closing were given new hope when the National Efficiency Board announced its intention in April 1917 to hold hearings on 'the liquor question'. ${ }^{27}$ The Board's report was submitted to the Minister of Defence on 9 July but was not presented to Parliament until the end of the month. ${ }^{2 x}$ By then there had been two delegations of business interests to Prime Minister William Massey to lobby for wartime early closing. ${ }^{29}$ On 20 July the Dominion reported rumours that the government had drafted a bill for eight o'clock closing. ${ }^{31}$ Less than two weeks later the NEB report on 'the liquor question' was made public. It recommended inter alia that six o'clock closing should be introduced 'without delay,." The report received significant press coverage and was praised by the Dominion newspaper for its 'courage.". Prohibitionists also

\footnotetext{
22 Minutes of the Monthly Tixecutive Meeting of the New 7ealand Alliance for 13 September 1916, in New 7ealand Alliance Records, MSY-5655, Alexander Turnbull Library.

23 Ninutes of the Monthly Fixecutive Meeting of the New Zealand Mlliance for 6 November 1916, in New Zealand Alliance Records, MSY-5655, Alexander Turnbull Library.

2+. Cocker and Murray, pp. 116-7.

25 Mulcare, 'The political economy of six o'clock closing', p. 8.

26 Minutes of the Monthly lixecutive Meeting of the New 7ealand Alliance for 1 November 1916 and 21 March 1917, in New Zealand Alliance Records, MSY-5655, Alexander Turnbull Library. Some prohibitionists may have opposed reduced hours on the basis that reduced drinking might undermine support for prohibition.

27 Ninutes for 26 April 1917 in National Efficiency Board Minute Book, Vol. 1, 2 February 1917 to 6 July 1918, New Zealand National Ffficiency Board: Minutes, qMS-1528-1529, Nlexander T'urnbull l ibrary.

28. Anckland Star, 31 July 1917, p. 2 .

29. Amkiland Star, 20 July 1917, p. 3. The story refers to a similar previous delegation. Sec also NZ1PD 1917, vol 180, p. 218.

30. Dominion, 20 July 1917 , p. 4.

31 'Report of the National Efficiency Board on the Liquor Question', AJHR 1917 H43. A, p.2.

32 Dominion, 1 . August 1917 , p. 4.
} 
understandably welcomed the board's report. ${ }^{33}$ The government finally relented in September 1917 when Massey confirmed earlier rumours by introducing a bill for wartime eight o'clock closing. ${ }^{34}$ After lengthy and heated debate the bill was amended at the committee stage to provide for six o'clock closing for the duration of the war and six months afterwards. ${ }^{35}$ The Sale of Liquor Restriction Act came into force on 1 December 1917..$^{36}$ Six o'clock closing had begun.

A year later, at the end of the committee stage of the Licensing Amendment Bill 1918, a member moved a new clause providing that 'Section 12 of the Sale of Liquor Restriction Act, 1917, is hereby repealed'. ${ }^{37}$ While this amendment sounds innocuous enough, the section to be repealed was the one ensuring that early closing remained in effect for no longer than six months after the end of the war. ${ }^{38}$ There was no debate and in the ensuing division a one-vote majority secured the change. ${ }^{39}$ The passing of the measure by a single vote as part of a Bill concerned with licensing polls was criticised in some circles. The Wellington Chartered Clubs sent a letter to senior Government Ministers protesting about the 'breach of faith' on the part of members of Parliament as ' $\mathrm{t}$ ] he people were given to understand that the imposition of six o'clock closing was a war measure only' ${ }^{40}$ Newspaper correspondents expressed similar views. ${ }^{41}$ When the Bill went to the Legislative Council some members expressed concerns about the manner in which the law had been amended. The Attorney General Sir Francis Bell said that, while he supported permanent early closing, he was not convinced it was being introduced fairly. Bell moved an amendment to provide for a referendum on the issue instead but was voted down by

\footnotetext{
33 The Alliance understandably received the Board's report with great enthusiasm, Vangrard, 11 August 1917, pp. 3, 5.

34 NZPD 1917, volume 180, p. 217.

35 N7P1) 1917, volume 180, p. 307.

${ }^{36}$ Salc of Liquor Restriction Act, New Zealand Statutes 1917, p. 89.

37 NZPD 1918, volume 183, p. 714.

38. Sale of Liquor Restriction Act, New Zealand Statutes 1917, p. 94.

39 N7PD 1918, volume 183, p. 714.

40. Dominion, 5 Iecember 1918, p. 5.

+1 Dominion, 10 December 1918, p. 6.
} 
his fellow legislative councillors ${ }^{42}$ The Licensing Amendment Act became law on 10 December 1918 and early closing became permanent. ${ }^{43}$

These basic facts as to how six o'clock closing came to be introduced leave unanswered the question as to why the hour of six o clock' in part is that New Zealand was following Australia's lead, for the Australian six o'clock closing campaign started well before the war. By 1911 all states had legislated for the compulsory closure of most shops after six pm and temperance campaigners were pushing for similar restrictions on hotels. ${ }^{44}$ A Methodist publication claimed it was a scandal that a country should close shops for the sale of bread, and keep open places for the sale of intoxicants until eleven' 45 The early closing campaign was waged fitfully in various states from 1900 onwards, and resulted in the South Australian government legislating in 1913 for a referendum on hotel opening hours. By the time the referendum was held in March 1915 the early closing campaign was given additional impetus by the patriotic fervour of the war effort, concerns about unruly behaviour among army recruits, and the example of restrictions in other countries. A clear majority of South Australians voted for six o'clock closing and the pressure went on for referenda in other states. By October 1916, New South Wales, Victoria and Tasmania had succumbed. Only Queensland and Western Australia continued to allow evening drinking.

In contrast in New Zealand there were no general restrictions after 1906 preventing shops opening in the evening. Although the law required many shops in larger towns and cities to close after six pm, there were a wide range of exceptions including bakers, chemists, fishmongers, florists, fruiterers and newsagents. ${ }^{47}$ The early-closing arguments used by Australian temperance campaigners therefore had limited relevance to New Zealand. In 1913 the only Alliance demand that linked the opening hours of shops and bars was that pubs should be shut on the 'half holiday' - the half day per week that most shops were

${ }^{+2}$ NZ2PD 1918, volume 183, p. 714 and pp. 815-7.

${ }^{13}$ Licensing Amendment Act, Nen Zealand Statutes, 1918, pp. 94-122. Section 2 of the Act made six o'clock closing permanent.

* This account of the Australian campaign is drawn from Walter Phillips, "Six O'Clock Swill: The Introduction of Early Closing of Hotel Bars in Australia', Historical Studies, vol. 19 no. 75, October 1980, pp. 250-266.

5 Quoted in Phillips, Six O'Clock Swill, p. 253.

16 The hous recommended by the Bfficiency Board were actually those normally observed by shops in New Zealand at the time, including one late night and one day of early closing at $1 \mathrm{pm}$. However, only the early closing day, known as the half holiday, was required by legislation, NYOYB 1914, p. 710.

77 Shops and Offices Act, New Zealand Consolidated Statutes 1908, volume v, PP. 390-391. 
required to close. ${ }^{48}$ The push for early closing in New Zealand did not begin until the war and, as outlined earlier, was strongly focused on wartime efficiency. But, as some newspaper correspondents argued, national efficiency could perhaps be better served by measures such as afternoon closing as introduced in England, whereas six o'clock closing appeared to encourage drinking during work hours. ${ }^{49}$ Wellington's Wellesley Club made this point in a letter to the Prime Minister late in 1917. 'The proposal is directly opposed to the principle adopted in Great Britain, where bars are closed during the hours of labour and open during the hours of relaxation. ${ }^{50}$ Indeed, the National Efficiency Board adopted something akin to the British principle when it looked into another alleged waste of resources, the cinema. In that case the Board suggested that 'public entertainments during the usual hours of labour should be prohibited' to deter absenteeism. ${ }^{51}$

So why did New Zealand temperance campaigners follow those in Australia in arguing for a measure that would inhibit drinking in leisure hours but not during those normally spent at work? The answer appears to be that advocates of six o'clock closing had concerns other than absenteeism. They were primarily interested in reducing the total amount of alcohol consumed, which was expected to lead to a healthier workforce and the various productivity improvements claimed by their campaign. Furthermore they believed this aim would best be achieved by closing bars during the high-consumption hours of early evening. ${ }^{52}$ In other words they subscribed to the restrictionist philosophy that shorter opening hours would mean less drinking. As a Christchurch cleric argued at an early closing rally, with bars open in the evening 'temptation is spread alluringly before our young men far into the night, ${ }^{5.3}$. The view that early closing would lead to lower alcohol consumption was held by most MHRs who argued for six o'clock closing. Even some of those who opposed the change agreed that it would result in less drinking, with several MHRs claiming that reduced hours was an unfair imposition on publicans or that it would

\footnotetext{
${ }^{48}$ Cocker and Murray, p. 112. The day varied on a regional basis on the decision of local authorities.

49 Dominion, 20 July 1917, p. 8 and 24 July 1917, p. 7.

30) Quoted in N/PI) 1917, volume 180, p. 219.

51 'Report of the National Efficiency Board', AJI IR 1917, II43, pp. 11-12. The Board indicated that it would recommend the banning of daytime picture shows if the war continued much longer.

52 Advocates for six o'clock closing during the war made few if any of the references to protecting home life that were typical of later debates. Steven Tiarly, "The Six O'clock Closing Debate', makes no mention of this issue. Of course temperance campaigners tended to attune their arguments to the circumstances of the day.

53 Quoted in V anguard, 16 June 1917, no. 702. p. 7.
} 
result in a significant loss of tax revenue. ${ }^{54}$ The union representing hotel and restaurant workers claimed that early closing 'would mean that a large number of members of our union would be thrown out of employment', a position supported by other unions. ${ }^{55}$ However several MHRs disputed that the restriction would necessarily result in less drinking. ${ }^{56}$ During the 1916 early closing debate Dunedin Central representative Charles Stratham suggested increased duties, which were known to affect consumption, would be a more sensible measure than six o'clock closing, which was 'only an experiment and may not have the effect its supporters anticipate. ${ }^{57}$ In 1917 the Speaker of the House agreed with the sceptics, ruling that it was uncertain whether or not six o'clock closing would result in reduced government revenue. He therefore rejected a last ditch argument that the six o'clock closing amendment was invalid because its fiscal implications meant the change could only be introduced as a government measure. ${ }^{58}$ However, to deal with the concern that publicans might lose business the Sale of Liquor Restriction Act allowed them to apply for rent reductions in the event of reduced liquor sales. ${ }^{59}$ As the Royal Commission on Licensing commented in 1946, these provisions proved unnecessary for '[i]t was found in practice that the hotels suffered no loss of revenue by six o'clock closing.(1)

With the imposition of six o'clock closing from 1 December 1917, New Zealand entered a new licensing era that was to last for 50 years. The reform did not mean that people could not buy a drink after six in the evening. Boarders and bona fide guests staying at hotels could get a drink at any time, and could buy drinks for their own guests. Furthermore, those dining at a restaurant situated in a hotel could be served with wine or beer until eight pm. ${ }^{61}$ Other restaurants could not serve alcohol, although people could provide their own as long as they finished dining by six. The small numbers of chartered clubs

\footnotetext{
5. See, for example, NZPD 1916, volume 178, p. 755 and N7.PD 1917, volume 180, p. 267. Fxcise duties on alcohol made up a significant proportion of government revenue at the time.

55 NZIPD 1916, volume 177, p. 304 and NZIPD 1917, volume 180, pp. 218-9. In 1917 the Prime Minister met a deputation of hotel and restaurant workers objecting to the proposal for six o'clock closing. The Auckland Hotel Workers Union presented figures showing that 44 of 46 mainly North Island unions they had contacted opposed early closing. Sec also Amkland Star, 23 July 1917, p. 2.

${ }^{56}$ NZPD 1916, volume 178, pp. 596-8, 743, and NZPD 1917, volume 180, pp. 247, 290, 307.

${ }^{57}$ NZPD 1916, volume 177, p. 275.

58 N7PD 1917, volume 180, p. 307.

${ }^{59}$ Salc of Liquor Restriction Act, New Zealand Statutes 1917, pp. 89-92.

${ }^{60}$ Report RCL 1946, p. 48.

${ }_{61}$ Sale of Liquor Restriction. Ict, New Zealand Statutes 1917, pp. 93-4.
} 
around the country were required to abide by legislated hours of sale, but members of these and other clubs could provide their own alcohol for on-premises consumption at any time.

In addition to these legal exemptions there was a lively after-hours trade. According to the 1945 Royal Commission on Licensing 'the evidence which we took shows clearly that large numbers of people in New Zealand have no hesitation in breaking these [early closing laws' ${ }^{62}$ Police officers and others provided evidence of the array of secret knocks, spotters, warning bells and escape routes used to avoid detection in urban hotels. ${ }^{6.3}$ Between 1918 and 1967 there were generally fewer than 2000 convictions per year for after-hours drinking, indicating that enforcement was either difficult or lax. ${ }^{64}$ One witness recounted how an overseas visitor was surprised to learn it was illegal to drink after six, having enjoyed evening drinks with a friend in a Wellington hotel oblivious to any legal impediment. ${ }^{65}$ When asked, witnesses in all parts of the country were generally quite open about having drunk in bars in the evening and on Sunday.

In rural areas and provincial towns enforcement was particularly difficult. The police were well known, drinking facilities were isolated, and the telephone proved a useful warning device when police staged a raid. At times the police provided the warnings themselves, as they and others in authority often sympathised with rural workers unable to get to the pub before closing time, and with publicans who had few legal customers. ${ }^{66}$ 'I have seen, on numerous occasions, country hotels where there has not been a customer all day,' testified a former policeman based in the Wairarapa in the 1930s. As a result he generally permitted after-hours trading and would regularly share an evening drink with local farmers at the Tinui Hotel. The majority of Wairarapa publicans kept their law-breaking 'within the bounds of decency,' he said. ${ }^{67}$ Many rural and provincial police continued to ignore the early closing law in subsequent decades. Some small town police were even alleged to moonlight as barmen after hours. ${ }^{68}$ In one revealing incident in the 1960 s the

\footnotetext{
62 Report RCI, p. 100.

63 Scc, for cxample, PRCL. pp. 1597-8, 2981, 3083-4, 5428.

${ }^{6}$ Some figures can be found in PRCL, p. 338, others in NZOYB, 1950 to 1968.

65 PRCL, pp. 1149-50.

$66 \mathrm{McJ}$ auchlan, Story of Beer, p. 138.

${ }^{67}$ PRCL, pp. 1596-7.

${ }_{68}$ Biggs, 'Some Political and Social Implications of Later Closing', p. 308. Police may have worked behind the bar to reassure the clientele of their immunity from prosecution.
} 
police in a North Island town cleared the bars at $9 \mathrm{pm}$ to recruit a posse to recapture escaped prisoners. The escapees were quickly returned to police custody and the pubs were full again by $9.30 .^{69}$

The loophole allowing hotel residents to be served at all hours proved a useful front for after-hours trading. A former newspaper editor recalled in 1992 that a delegation of prominent citizens took him to a local hotel within days of his taking up a position in Whakatane. The Mayor pushed the after-hours bell three times and the party signed a register as evidence they were paying guests at the hotel. The bar was packed although it was after seven pm. ${ }^{70}$ Gordon McLauchlan, who regularly stayed at hotels in the mid1960 s, wrote that fellow journalists would frequently ask him to sign them in as guests for after-six drinking. In some cases he agreed to proprietors' requests to sign for people unknown to him. ${ }^{71}$ Senior police told the 1946 Commission that, given the difficulty in determining if someone was a genuine guest or not, the special privileges for guests and lodgers should end or at least be curtailed. ${ }^{72}$ The idea that a hotel was a home away from home was well entrenched and there is no evidence that the government ever contemplated interfering with the liquor consumption of guests either then or later. In fact it was not until 1961 that any limit was put on the age at which guests could be served with drink in a hotel dining room. ${ }^{73}$

Despite widespread legal and illegal after-hours drinking in bars, it appears that most drinkers complied with the law and simply changed their drinking behaviour to fit in with the reduced hours. Daytime drinking on Saturdays became the norm. In 1945 an observer in an Invercargill bar counted 87 people at $10.30 \mathrm{am}$ and some 250 at $12.15 \mathrm{pm}$, with many patrons 'well inebriated'. ${ }^{74}$ The speed of consumption was increased to allow for the restricted time available after work, leading to the notorious 'six o'clock swill'. The brewing industry also introduced technical innovations to deal with the problems caused by a shrinking number of pubs and contracted periods of large-scale demand. From the

\footnotetext{
69) Biggs, 'Political and Social Implications of Later Closing', p. 308.

70 Cedric (iray in the New Zealand Herald, 10 October 1992, p. 11. Gray says that the purpose of the expedition was to obtain his assurance that the names of convicted after-hours drinkers would not be published, to avoid 'unhappy marriages'. Unfortunately Gray does not provide a date for these events.

71 Mcl auchlan, Story of Beer, p. 138.

${ }^{72}$ See PRCL pp. 545, 861-2, 1416.

73 Bollinger, 1967, p. 59.

7t PRC.L, p. 2159. The day of the week for the observations was not recorded, but it was presumably a Saturday.
} 
late 1940 s they began replacing traditional beer barrels with motorised tankers similar to those used to transport petroleum. Carbonated beer was then transferred to tanks in hotel cellars from where it was easily dispensed by hand-squeezed taps affixed to plastic hoses. This innovation was sufficiently recent in 1959 to arouse comment from one observer: 'In many cities the crowd around the bar is so thick that instead of filling glasses from the old-fashioned beer pumps, the hotel staff takes the beer to the glasses by long, flexible plastic hoses - a dreadful sight to those unused to it. ${ }^{75}$ A dreadful sight perhaps, but the innovation enabled beer to be dispensed with great speed.

Demand for takeaway liquor also grew in the face of the restrictions. Witnesses testified to the 1945 Royal Commission on Licensing about broken bottles in the streets after closing time and a senior police officer talked of problems resulting from takeaway liquor. $^{76}$ A doctor claimed he frequently saw men leaving hotels with 'five or six quart bottles of beer. ${ }^{77}$ Overseas visitors made similar observations. ${ }^{78}$ For reasons of economy, bulk purchase was frequently in the form of draught beer pumped into half gallon flagons - the legendary 'half-g', also known as a 'jar' or 'peter.' ${ }^{79}$ McLauchlan provided a good description of the part they played in New Zealand's drinking culture:

Half-gallon jars, or flagons, became popular during The Swill. They were filled with the same draught beer available in public bars to take home for evening or weekend drinking. Drinkers could take their own washed flagons or swap their empties for those pre-filled and corked ready for sale. Some hotels had large flagon-filling stations, usually in or near the bottle store. Flagon beer would keep for up to 48 hours lying sideways in the fridge, but once opened needed to be drunk at one session - no great hardship during the fairly bleak days of the quiet old Kiwi weekend. ${ }^{80}$

Flagons were often purchased on Saturday afternoons in order to fuel regular Sunday drinking sessions. Much drinking also took place on Friday and Saturday nights.

\footnotetext{
75 Leslie ILobbs, The Wild West Coast, Christchurch, 1959, p. 37.

76 PRCL, PP. 898, 1859 and 2737.

77 PRCI. p. 3536.

78 . Anckland Star, 19 September 1947, p. 4. Ella Shiclds was American-born and a noted male impersonator.

79 Harry Orsman, ed, A Ditionary of Modern New Zealand Slang, Auckland, 1999, p. 62.

so Mclauchlan, Story of Beer, p. 155.
} 
According to an American observer, 'rowdy drunken parties' were commonplace in 1950 s New Zealand. ${ }^{81}$

The West Coast was notorious for after-hours drinking. Leslie Hobbs in his 1959 book The Wild West Coast recounts a number of amusing anecdotes, drawn from newspaper files and oral history, concerning the on-going battle between the police and those who believed that 'the time for a man to have a drink is when he feels like it and not when the government says so. ${ }^{82}$ One story recounts how a police raiding party found a local magistrate among evening drinkers in a bar. 'All boarders I see,' said the sergeant before leading his men in a dignified exit. ${ }^{83}$ In reality West Coasters' defiance of the law may have resulted as much from the practicalities of their work as from an independent spirit. Factors such as isolation and work hours often made it difficult for miners, timber workers and wharfies to make it to the pub within legal hours. ${ }^{84}$ The sheer number of pubs on the coast - Buller and Westland had 132 hotels between them in 1937 - probably also encouraged after-hours drinking, for several reasons. ${ }^{85}$ Firstly, the local bar would have been more significant as a community social centre than in other parts of the country where pubs were less common. Secondly, intense competition would have made publicans unwilling to turn away after-hours trade despite the prosecution risks. Thirdly, the plethora of bars would have made enforcement even more difficult than elsewhere. It is therefore not surprising that as early as 1923 a petition from the West Coast was presented to Parliament asking for an end to six o'clock closing. ${ }^{86}$ As previously noted, MPs in the 1920s were in no mood to tinker with the liquor laws and the petition was ignored.

The establishment of the Royal Commission on Licensing in 1945 gave West Coasters a further opportunity to vent their concerns. Miner George English made representations on behalf of miners unions in Runanga and Buller. Six o'clock closing, he said, 'has only

\footnotetext{
81 David Ausubel, The Fern and the Tike - an American View of New Zealand: National Character, Social Attitudes and Race Relations, Sydney, 1960, p. 52. 
made law-breakers of men who are usually law-abiding citizens'. ${ }^{87}$ The miners requested evening and Sunday opening due to the hours they worked, Sunday being their only full day off. ${ }^{88}$ West Coasters were far from the only ones to express dissatisfaction with early closing. Supporters of evening opening far outweighed its detractors among those making submissions to the royal commission. Most police witnesses and several magistrates testified in support of evening opening, including the Commissioner of Police, a teetotaller. ${ }^{89}$ Their rationale in the main was that they did not foresee any particular harm emerging from bars being allowed to open for a few hours in the evening.

Witnesses complained about pubs being open primarily while people were at work. 'I cannot see any necessity for opening a hotel in the morning at ten o'clock and keeping it open all day and then closing it in the evening when the public who would patronise it could go along and enjoy a drink' an Auckland Power Board employee told the commission. ${ }^{90}$ A Wellington waterside worker put in a plea to be able to get a drink after work rather than during work hours." The Dunedin Licensing Committee blamed afterhours trading on the fact that 'numbers of men have to work ordinary and overtime during the time hotels are open', ${ }^{92}$ Many submissions were made on behalf of rural people, a group whose work hours commonly precluded them from enjoying a legal drink, for similar reasons to those applying on the West Coast. Some who supported early closing proposed that later closing could apply in country districts. ${ }^{93}$ The final report of the Royal Commission was highly sympathetic to the plight of rural workers. ${ }^{94}$

But the social consequences of early closing were the main concern for its opponents. They claimed the limited time available for drinking on weekdays led to over-crowded bars, rushed drinking, and the custom quaintly known as 'vertical drinking' in which customers invariably stood rather than sat down for a drink. The picture painted by the evidence presented to the Commission was often far from pretty. "They are three or four deep, and drinking not as human beings, but often like animals, fighting to get it, and

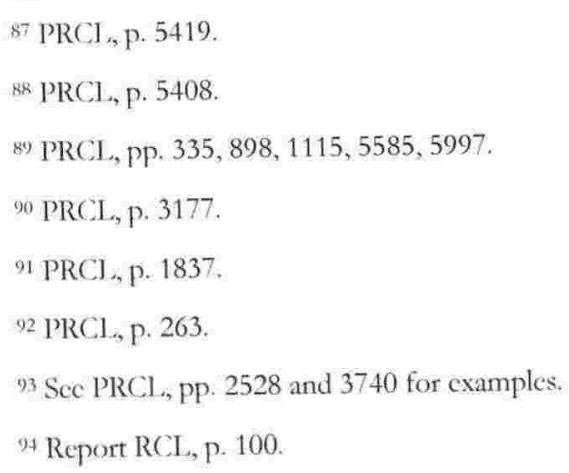


passing handles over each other's heads,' said a witness of some Wellington bars." Continuing with the animal imagery, a Wellington clerk testified to drinkers lined up five or six deep at the bar like so many pigs going to the same trough,. ${ }^{96}$ Other witnesses also blamed six o'clock closing for overcrowding, poor drinking habits and drunkenness. 'I think the excessive drinking between five and six o'clock has a tendency to encourage intoxication,' Police Commissioner James Cummings told the Royal Commission. There is, he said, 'a fair amount of swilling.' consumption of alcohol could be achieved...in a more leisurely and sociable manner, many of the present shortcomings might be avoided'. 98

Many advocating evening drinking drew on their overseas experiences. Only a few returned servicemen testified, as the commission was established while the war was still underway. However some commissioners appear to have spoken to servicemen outside of the hearings, for they were clearly under the impression that this group overwhelmingly favoured more relaxed drinking hours." One who did testify after serving in the Middle East found conditions in Auckland a 'jolt'. Bars, he said, 'resemble a rugby scramble and it requires a sturdy forward to push through the scrum and obtain a drink'. Because of the restricted time, 'many men who would otherwise be able to drink quietly and intermittently as the fancy might take them ... in many cases literally guzzle? ${ }^{100}$

In contrast, many publicans and industry representatives who gave evidence supported six o'clock closing, including the Auckland Licensed Victuallers' Association. ${ }^{101}$ The official position put to the commission by the National Council was for staggered hours that would allow for evening drinking but would not increase the total hours bars were open. ${ }^{112}$ However the National Council presented no evidence in support of these hours. Prominent brewery bosses Eliot Davis and Henry Kelleher made it clear that their

\footnotetext{
${ }^{95}$ PRCL, Pp. 1379-80.

96 PRCL, p. 1739.

97 PRCI, p. 1135.

${ }_{98}$ PRCL, p. 345 .

99 Sec PRCL Pp. 1543 and 5632.

100 PRCL, p. 3173.

101 PRCI, pp. 3740, 3754-7, 3869, 3893, 4107-8.

102 Conrad Bollinger suggested, perhaps not unfairly, that the industry advocated broken hours so there would be two rush times instead of just one, Grog's Onn Country, 1967, pp. 105-6.
} 
support for evening opening was in a purely personal capacity. ${ }^{103}$ Trade representatives who supposedly supported the hours officially advocated by the National Council emphasised their disadvantages. Six o'clock closing 'makes for easiness in hotel management,' said a director of New Zealand Breweries. 'Extra labour costs owing to broken hours would be a difficulty and increase overhead,' although of course 'the convenience of the public would appear to be the paramount consideration'. 104 Publicans were generally more open about their self-interest in advocating retention of six o'clock closing. Early closing means the publican 'has not to worry about extra staff,' said David Lusk of the Star Hotel in Kawakawa. ${ }^{105}$ Another admitted that, while as a customer he would like to be able to drink in the evening, as a publican he liked the convenience of six o'clock closing. ${ }^{116}$ The hotel workers union also supported the retention of six o'clock closing in its submission to the commission. ${ }^{107}$ Hotel workers had made significant gains in real wages from the increasingly restrictive drinking laws. Lower-paid workers such as young people (due to the raising of the drinking age) and women (at least as new entrants) had been banned from the profession in 1910, and bar staff did particularly well during wartime manpower shortages, as they could not be replaced by women. ${ }^{108}$ After 1917 it was clear that hotels had suffered no decline in turnover, and hotel workers had gained shorter and more sociable hours with no drop in pay.

The Royal Commission took notice of the thrust of the submissions and recommended limited evening sales of liquor along the lines proposed by the National Council. This proposal received much publicity in the daily newspapers when the commission's report became public in September 1946. When the Auckland Star conducted a vox pop exercise a non-drinking housewife from Epsom argued that later closing would be good for family life, for with the prospect of evening drinking 'men would be more likely to arrive home from work early rather than well after $6 \mathrm{pm}$. ${ }^{109}$ A barman who disagreed with the proposal for broken hours had a different view. 'Fellows wouldn't go home to their tea. They'd wait in town for the pubs to open.' A cabaret manager thought evening hours

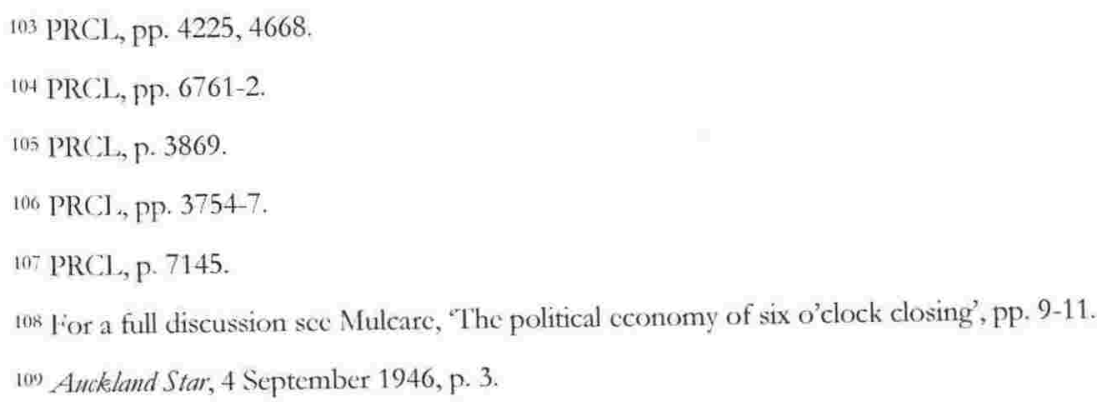


'might stop New Zealanders gulping their liquor and learn to drink the European way'. A well-travelled teetotaller clergyman told the paper that 'it isn't that we drink too much in New Zealand but we drink the wrong way. The six o'clock 'pigs around the trough' business is a disgrace. ${ }^{110}$

Given such widespread support for extending opening hours, why was six o'clock closing overwhelmingly endorsed in a referendum just three years later? The official record of the royal commission's proceedings provides some clues. Many witnesses did not accept that the conditions described were caused by early closing. The mayor of Rotorua, a large town with only four pubs, told the commission he was unsure if it was six o'clock closing or the restriction on licences that caused the problems. ${ }^{111}$ Others came down firmly on the side of the latter explanation, or thought that bars should be larger. ${ }^{12}$

Another group considered that the allegedly appalling drinking conditions and habits were a result of something in the national psyche rather than the drinking laws. As a Napier Magistrate told the Commission, he wouldn't support later closing unless 'the present system of vertical drinking and intensive shouting is greatly altered'. ${ }^{113}$ Harry Squires, a Wellington City Missioner who had emigrated from England 11 years earlier, was appalled by the conditions in some Wellington bars, which he compared unfavourably with conditions in England. ${ }^{114}$ But he was firmly against extended hours under 'present conditions', as New Zealanders 'were not educated to decent drinking. ${ }^{115}$ His position has some logic to it. If things were so appalling, why would anyone want it to go on longer? According to a 1949 Auckland Star editorial, supporters of early closing argued that bad habits have become ineradicable, and that the long tradition of excessive drinking would make it almost impossible to educate the public, within reasonable time, in the adoption of more graceful ways'. The Star showed some sympathy for this viewpoint. 'The people are being asked to vote for night drinking hours without any assurance, from the licensed trade or any other quarter, that anything will change. This fact will almost

\footnotetext{
110 Auckland Star, 4 September 1946, p. 3.

111 PRCL, p. 4388.

112 Charles Griffin of the Hutt Valley Chamber of Commerce is just one cxample. He was appalled at the overcrowding in local pubs, but had no view on opening hours, PRCI, pp. 1366-7.

113 PRCL, p. 155.

11+ PRCL, PP. 1379-80, 1388.

115 PRCL, Pp. 1380, 1389.
} 
certainly bring about the defeat of the ten o'clock proposal'. ${ }^{116}$ Poet A.R.D. Fairburn put the same view later in the year with benefit of hindsight. 'It seems probable that many people who would like to enjoy decent conditions were unable to bring themselves to vote for an extension of piggishness until ten o'clock. They can hardly be blamed.'117

Another relevant factor is the attitude of prohibition and temperance groups and their supporters. In 1949 they were still, in the main, firmly united in support of six o'clock closing. The Methodist conference in 1949 confirmed its opposition to later closing and the Presbyterian Church testified in favour of six o'clock closing to the Royal Commission. ${ }^{118}$ That groups allegedly supporting temperance should continue to support the rapid consumption and the widely-attested piggish behaviour of 'the swill' is perhaps in need of explanation. One possible reason is that many people did not see a necessary connection between the prevailing drinking conditions and the opening hours. Indeed, for prohibitionists the piggish behaviour of the swill probably provided additional confirmation of the evils of alcohol. In addition the continued existence of these conditions may have been seen as maintaining support for prohibition, or at least as discouraging new drinkers. The swill was also perhaps seen as a lesser evil than having families regularly abandoned in the evenings by dissolute husbands.

Lobby groups who had traditionally supported alcohol restrictions did not present a completely united front on closing hours in the 1940s. A combined submission to the royal commission on behalf of the Presbyterian, Methodist and Congregationalist Churches, the Society of Friends and the Salvation Army stated that 'some are prepared to see a change in the times' - provided that evening drinking was first approved in a referendum. ${ }^{119}$ The submission from the National Council of Women's Public Opinion Group declined to express a view on hours, as members had varied views, including some who wanted later closing. ${ }^{121}$ However these disagreements were minor and sometimes

\footnotetext{
116 March 8,1949, p.2.

117 Quoted in Bollinger, 1967, p. 111.

118 Auckland Star, 22 February 1949, p. 3 and PRCl, p. 3138.

119 PRCL, p. 2451.

${ }^{120}$ PRCL, p. 1675.
} 
short-lived - the National Council of Women reaffirmed its support for six o'clock closing at its 1947 national conference, a position it did not abandon until $1966 .^{121}$

The availability theory also played a hand in the referendum result, in particular the longstanding belief that earlier closing had led to reduced drunkenness, and to a lesser extent in lower alcohol consumption. There had, submitted the Presbyterian Church, been a decline in drunkenness since six o'clock closing. ${ }^{122}$ Any extension of hours would lead to an increase in drinking said a National Party MP in 1947, and the Alliance made a similar claim in its 1949 referendum campaign. ${ }^{123}$ Such claims probably seemed plausible in the 1940s for, the swill aside, New Zealand was a relatively temperate society. Per capita alcohol consumption was modest by international standards and the rate of drunkenness convictions was historically low. ${ }^{124}$

The revival of the cult of domesticity after the depression was an important factor in the result of the 1949 referendum. Many new families had been formed in the years immediately before and after the war. Both government and opposition were overtly profamily and pro-natalist in their policies and pronouncements. National and Labour were locked into an arms race on domesticity, each trying to outdo the other in their defence of home and family. ${ }^{125}$ Witnesses to the Royal Commission routinely commented on the problem of increasing numbers of women drinking in bars, and the policy of some hotels to eject women from lounge bars by five pm was greeted with universal approval. ${ }^{126}$ The prevailing view appeared to be that home rather than the bar was where women should be, to be joined by her breadwinning husband as soon as possible after he finished work. In 1949 the Alliance emphasised to its supporters the importance of early closing for domestic life. Issues of V anguard in the two months before the referendum showed idyllic scenes of domestic bliss thanks to six o'clock closing. ${ }^{127}$ Alliance campaign posters for the 1949 referendum were almost a parody of what Belich has termed 'romantic

\footnotetext{
121 Vanguard, April 1947, p. 40 and Submissions to the Royal Commission on the Sale of Liquor, Archives New Zealand COM 21/8, submission 53, p. 4 .

122 PRCl, pp. 3143-4.

123 NZPD 1947, volume 278, p. 588 and Otago Daily Times, 5 March 1949, p. 8.

12+ See Chapter 6 for more information.

125 Melanie Nolan, Breadwinning: New Zealand Women and the State, Christchurch, 2000, p. 193

126 Women rarely drank in public bars - indecd it was commonly belicved until the 1970s that they were legally barred from doing so, NZOYB 1990, p. 566. Some hotels provided lounge bars', with nicer surroundings and higher prices, where women could drink together or with 'escorts'.

127 V anguard, January and February 1949.
} 
domesticity. ${ }^{128}$ One showed a Norman Rockwellesque scene of parents and young children enjoying the 'happier home life' that would presumably be impossible if pubs were allowed to open after six pm. ${ }^{129}$ Another declared that 'happiness depends on the home!' and exhorted voters to 'help preserve family harmony. ${ }^{130}$ The message appeared to have struck a chord with many. McLauchlan recalled that his father, 'an enlightened, liberal man', voted for continued six o'clock closing because 'without it family life would be wrecked'. ${ }^{131}$

The availability theory and the cult of domesticity were a powerful combination, for many feared that the prospect of later drinking would tempt men to forego their dinner and neglect their families. As a witness to Royal Commission stated, "we do not want fathers and mothers drinking in hotels in the evening, when they should be home with their children'. ${ }^{132}$ The commission found that even supporters of evening opening frequently advocated that bars should close for a period after six pm. One witness, typical of many, wanted bars closed between six and seven pm 'so that people will go home for the evening meal.'.33 An Auckland police sergeant wanted a break between six and 7.30 as 'a certain class of drinker would linger on and neglect of his family would result'. ${ }^{134}$ Even the Buller miners wanted the pub closed from six to seven, and others also suggested staggered hours. ${ }^{135}$

The 1949 referendum provided no avenue for the expression of such viewpoints. Instead it provided a simple but inflexible choice: 'I vote for closing at six pm', or 'I vote for closing at ten pm', with the voter to cross out the option they disagreed with. ${ }^{136}$ But these

\footnotetext{
${ }^{128}$ Belich, Paradise Reforged, pp. 490-3.

129) 'Vote 6 o'clock closing!', Alexander Turnbull Library pictorial collections, reference number Eph-C-ALCOIIOLHours-1948-03.

130 'Ilappiness depends on the home!, Alexander Turnbull Library pictorial collections, reference number Eph-CII.COHOI,-Hours-1948-02.

131 Mcl auchlan, Story of Beer, p. 139.

132 PRCL, p. 3016.

133 PRCL, p. 4564.

13+ PRCI, p. 2809

135 PRCL, p. 5408. A number of licensing committec submissions also suggested staggered hours or closing at 8 or $9 \mathrm{pm}$. Licensing committee reports are contained in volumes 1 and 2 of the PRCL.

136 Licensing Imendment Lct, New Zealand Statutes 1948, p. 996. The fine print on the ballot paper elaborated the ten o'clock option as 'opening... for a total of 9 hours, at times to be decided, between 10 am and ten pm.' There did not appear to be any publicity in the media about this qualification, which seemed to contradict the wording of the question people were voting on.
} 
are only two among a wide range of alternatives. Many voters may have supported neither option, causing them to refrain from voting or opting for the safety of the status quo. Those advocating later closing to the 1945 royal commission had proposed a variety of closing hours, some as early as seven $\mathrm{pm}^{137}$ The varying views on hours were not reflected in the referendum question because no significant interest group advocated later closing. There is no evidence of any submissions being made to the select committee on the issue, or of the MPs on the committee having discussed the opening hours referendum at all. ${ }^{138}$ Eighteen years later the 1967 referendum allowed for a much wider range of viewpoints, as the choice presented to voters was between six o'clock and 'later closing. ${ }^{139}$ The question was deliberately designed by the Statues Revision Committee to ensure that voters were not presented with two rigid options. As MP Colin Moyle told Parliament at the time, '[o]ne of the reasons why the 1949 referendum was defeated was that it was not sufficiently flexible. It was not a question of a decision between change and no change. It was too specific. The specific $10 \mathrm{pm}$ closing option cost the section of the community desiring a change many votes indeed.' ${ }^{141}$

The two main political parties generally supported early closing, although there was some opposition. Two MPs spoke in support of evening drinking when the Royal Commission's report was discussed by Parliament in 1947, with one saying it would 'stop the deplorable rush just before six o'clock', ${ }^{141}$ However Deputy Prime Minister Walter Nash told Parliament in 1948 that he strongly supported six o'clock closing, and was confident in its retention given the support of both the prohibitionists and the trade. ${ }^{142}$ Opposition leader Sid Holland also supported early closing. ${ }^{143}$ The fact that the Government did not accept the Royal Commission's recommendation on hours, and instead put the issue to a referendum it was confident would be lost, shows it was happy with the status quo.

\footnotetext{
${ }^{137}$ For some examples sec PRCL pp. 335, 3879, 3948, 5585, 5886, 5904, 5996.

138. The Dominion reported on the main submissions on the licensing Amendment Bill 1948 on 25 November 1948. There was no mention made of the opening hours issue. The select committee report to Parliament did not mention the referendum.

${ }^{139}$ Sale of Liquor Poll Act, Nem Zealand Statutes 1967, p. 65.

140 N7PI) 1967 volume 351 , p. 2029,

141 N/PD 1947, volume 278, p. 596.

142 NZPD 1948, volume 283, p. 4213.

143 NZPD 1947, volume 278, p. 704.
} 
Parliament did not discuss the Royal Commission's report until a year after its release, mainly because a general election intervened. The government procrastinated a further year before legislating to put into effect some of the commission's recommendations. The referendum on six o'clock closing took place another six months later. Support for change may have been greater without this 30-month delay. For example, publicity for the commission's nationalisation recommendation was followed by a 50 percent increase in the vote for state control in the 1946 triennial licensing poll held shortly after. By 1949 the report of the Royal Commission was long forgotten and the state control vote had dropped back to previous levels. ${ }^{144}$ The same fate befell the commission's recommendation for evening opening.

While the government procrastinated, liquor control was overshadowed by another social issue - gambling. The Government had agreed to a commission of inquiry before the war, and it was reconstituted in 1946. The issues generated much interest and the commission heard 625 submissions between November 1946 and February $1947 . .^{145}$ When the Gaming Commission reported in January 1948 it endorsed a Racing Conference proposal to provide for legal off-course betting through the totalisator. ${ }^{146}$ The commission's recommendations reflected the submissions it received, and were met with 'almost universal acceptance.' ${ }^{147}$ The government, with a small majority and a number of socially conservative MPs, decided to put the totalisator proposal to the people on 9 March 1949. For efficiency, the opening hours referendum was held on the same day.

The ninth of March 1949 was to be the first time in New Zealand's history that any issue other than the prohibition of alcohol was to be the subject of a national referendum. Given this fact, the two referendums generated surprisingly little public interest. The New Zealand Herald found that on polling day 'the atmosphere seemed, for the most part, one approaching apathy. ${ }^{148}$ Only 56 percent of registered voters turned out to vote. One reason for the apathy may be that the results of both referendums were considered by voters to be a foregone conclusion. A recent high profile royal commission had recommended off-course betting as a way of suppressing bookies and its widespread

144 The vote for State Purchase and Control increased from 13 percent in 1943 to 20 percent in 1946. It reverted to 13 percent in 1949 .

145 David Grant, On a Roll: a History of Gambling and Lotteries in New Zealand, Wellington, 1994, p. 126.

$1+6$ On-course totalisator betting was already allowed.

thi Grant, On a Roll, p. 128.

1+8 New Zealand Herald, 10 March 1949, p. 6. 
support by liberals and conservatives alike was assured. ${ }^{149}$ New South Wales voters had decisively rejected later closing in a 1947 referendum on hotel hours and the Deputy Prime Minister confidently predicted that New Zealand voters would do the same. ${ }^{150}$ The fact that many voters supported neither option offered in the referendum would also have contributed to non-voting.

The almost complete lack of campaigning on the issue of hotel hours probably also contributed to the apathy. The liquor industry, reassured by the benign 1948 Licensing Amendment Act, dropped any pretence of desiring reform and adopted a neutral stance that made it clear that it supported the status quo. On 25 February, less than two weeks before the poll, the National Council announced the already obvious fact that it was taking 'no organised action to influence the public. ${ }^{151}$ With no opposition the Alliance campaign was low key, indicating it was confident of victory. It advertised on cinema screens, but placed few newspaper advertisements. ${ }^{152}$ In the country's largest city, it placed one advertisement in each of the daily newspapers, both the day before the referendum. ${ }^{153}$ The Alliance advertisement in the Herald included the words ' 6 is the more moderate hour'. By a strange coincidence a New Zealand Breweries advertisement on the same page described fine ale as 'the beverage of moderation', and exhorted readers to 'be moderate'. The advertisement was illustrated with a domestic scene - a man in an easy chair with his pipe and newspaper - and appears to have been a one-off. ${ }^{154}$ It was not to be found in any other edition of the Herald in the first three months of 1949.

Whether or not New Zealand Breweries had co-operated with the Alliance in a subtle show of unity, the industry was less subtle in showing its true colours after the referendum. 'After 30 years of 6 o'clock closing the public has shown that they prefer it and do not wish to experiment with late closing hours,' said Percy Coyle, by then the Director of the National Council. 'The licensed trade did not participate actively in the campaign for the extension of hours, preferring to leave it to the popular vote, which in a

\footnotetext{
149 The vote in the racing referendum was more than two to one in favour of off-course totalisator betting, Grant, On a Roll, p. 129.

${ }^{150}$ Lewis, A Rum State, pp). 76-7 and Kirkby, Barmaids, p. 176.

151 Reported in the Amkland Star, 8 March 1949, p. 3.

152 Vanguard, January 1949, p. 7.

153 Auckland Star and New Zealand Herald, 8 March 1949, p. 5.

15t New Zealand Herald, 8 March 1949, p. 3.
} 
democratic country must be the only way to decide such an issue. ${ }^{, 155}$ The trade's newlyacquired belief that campaigning was incompatible with democracy did not last long. Eight months later it campaigned strongly for continuance in the lead up to the triennial licensing poll, placing seven advertisements in the New Zealand Herald. ${ }^{156}$ McLauchlan speculated with some plausibility that the industry's attitude may have been influenced by such factors as the likelihood of high penalty rates under extended hours due to the tight labour market of the time. ${ }^{157}$ The National Council also probably wished to avoid antagonising a significant number of publicans by supporting a referendum option that many of them disagreed with and that would almost certainly be defeated anyway.

The almost complete silence from lobby groups and the government meant that the press also contained minimal coverage of the impending referendum. When the Auckland Star surveyed its own files a few weeks before the 1949 poll it could find only one comment on the closing hours issue in the previous year - and that was Nash's confident prediction that six o'clock closing would be retained. ${ }^{158}$ Four major daily newspapers contained little coverage of either referendum in the months before the 9 March poll. ${ }^{159}$ The off-course betting issue received more coverage than hotel opening hours, and was the subject of many more letters to the editor. There seems little sense of any awareness of the historic significance of the occasion on the part of newspaper editors or the public. The Auckland Star lamented two weeks before the poll that it may be asked whether, in the history of New Zealand, has so little ever been done to inform the public concerning important questions prior to a national referendum'. ${ }^{161}$ Despite this, the paper showed none of the journalistic initiative it had exhibited in earlier years by hunting for news rather than reporting press releases. The Star was the only paper among those surveyed to express a view on closing hours in an editorial.

\footnotetext{
155 Otago Daily Times, 10 March 1949, p. 6. It is clear from Coyle's minority report as a member of the Royal Commission on I.icensing that he personally favoured later closing.

156 New Zealand Herald, 5 November 1949, p. 7, 9 November, p. 5, 14 November, p. 8, 19 November, p. 7, 25 November, p. 10, 26 November, p. 12, and 29 November, p. 3. The Alliance placed five advertisements over the same period.

157. Naclauchlan, The Story of Beer, p. 139.

158 Auckland Star, 23 February 1949, p. 2.

(59) 'The papers were the Anckland Star, the Auckland Herald, the Dominion and the Otago Daibr Times.

160 Amcland Star, 23 February 1949, p. 2. Is with the other papers, the Star seemed little aware of the uniqueness of these particular referendums.
} 
Most of those who favour the later hour have seen the less hasty ways of drinking in countries abroad, where hotels and cafes and other places in which alcoholic drinks may be enjoyed, without infringement of the law, remain open in the evenings, and in which few customers are given to excesses. In some of its aspects 6 o'clock closing, which makes for a stampede of drinkers, bent on getting their fill within the only possible hour after 5, makes for repellent and positively disgraceful habits. As the English magazine Punch observed not long ago, men emerge at 6 'sloshing like wet tarpaulins'. ${ }^{16 !}$

'Repellent' and 'disgraceful' things may have been, but clearly most New Zealanders were happy to keep then that way. There was a three to one majority in favour of six o'clock closing in the 1949 referendum. However the low turnout meant that only 43 percent of eligible electors had actually voted for its retention, while a larger group either failed to vote or cast informal votes. ${ }^{162}$ Apathy was the true winner on the day.

A few months after the referendum the government established the Licensing Control Commission to oversee the licensing laws. Despite the referendum result the LCC became a consistent critic of six o'clock closing. In its 1952 report the commission detailed at length its distaste for rush-hour drinking conditions, which it contrasted with the 'leisurely and sociable' conditions it had found on the West Coast. The LCC attributed the superior drinking conditions on the Coast, along with its reportedly low incidence of drunkenness and crime, to the fact that early closing was almost universally ignored there. ${ }^{163}$ The reversion to ten o'clock closing in New South Wales in February 1955 initiated a flurry of activity in relation to drinking hours. The Dominion newspaper blamed six o'clock closing for the 'hectic rush and swallow of the drinking New Zealander' and suggested the country should follow the New South Wales example. ${ }^{164}$ The Australian reform provoked particular interest in provincial areas. In July 1955 the Marlborough Licensing Committee wrote to the Chair of the LCC expressing concern at the number of prosecutions for after hours drinking in their district. They suggested reforms allowing later closing as in a district such as Marlborough very many seasonal workers do not cease work until after dark.' ${ }^{165}$ Their position was supported by other

\footnotetext{
161 Autkland Star, 8 March 1949, p. 2.

162 Of the 1,113,852 voters on the electoral roll, 473,768 voted for six o'clock closing, and 486,243 were informal or nonvoters, NZOYB 1950, p. 886.

163 Report of the Licensing Control Commission for the year ending 31 March 1952, AJIIR 1952, II. 3, pp 6-7.

tot Dominion, 23 May 1955, p. 8 .

165 Letter dated 21 July 1955 in Licensing Control Commission file, 'Suggested Changes in Licensing Hours', Archives New Zealand, AADM, 567, 13e, 4/1/26.
} 
licensing committees once their letter was circulated by the LCC. ${ }^{166}$ A petition was initiated in the South Island in support of allowing bars to close later in rural areas. ${ }^{167}$ In April 1959 support for the idea of later rural closing came from an unexpected source Oswald Mazengarb, a retired lawyer best known for his chairing of the Special Committee on Moral Delinquency in Children and Adolescents in $1954 .{ }^{168}$ A 1960 Gallup Poll showed public support for later drinking hours in country areas. ${ }^{169}$

But the 1949 referendum cast a long shadow. The members of the parliamentary select committee on licensing visited Sydney in 1960 to observe the effects of evening opening. Their report was positive but recommended that 'conditions are not propitious for an immediate change from 6 o'clock to ten o'clock closing. ${ }^{170}$ The reasons for the committee's recommendation included the 'decisive vote' in 1949 and the lack of evidence as to how far public opinion had since changed. ${ }^{171}$ Yet just seven years after the 1960 select committee rejected later closing, primarily due to a reputed lack of evidence for public support, a referendum on hotel opening hours recorded a decisive majority in favour of change. ${ }^{172}$ What had happened in the intervening years for there to be such an apparently dramatic turnaround?

One noticeable change was in the attitude of the industry towards evening opening. In 1955 the National Council made an unexpectedly firm statement in favour of ten o'clock closing, stung by tourism industry claims that it favoured the status quo. ${ }^{173}$ Despite this, the trade made no submissions on opening hours to the select committee in 1960 , perhaps due to ongoing internal divisions over the issue. ${ }^{174}$ But over the next few years both the Hotel Association and the National Council started lobbying for more flexible

\footnotetext{
166 Licensing Control Commission file, 'Suggested Changes in Licensing Hours', Archives New 'Lealand A. IDM, 567, $13 \mathrm{e}, 4 / 1 / 26$.

167 Southland News, 22 September 1955.

168 Soutbland Times, 20 April 1959. Nazengarb's support for reform was surprising given that a fellow committec member, a Presbyterian minister, later described him as 'a puritan with a simplistic view of society', J.S. Somerville, Jack in the Pulpit, Duncdin, 1987, p. 134.

169) New Zealand L icensee, 20 February 1961, p. 29 and Stace, p. 23.

170 Report of the Committee on Licensing, AJI IIR 1960, L.17, p. 31.

171 Committee on L icensing 1960, p. 27.

172 New Zealand Gazette 1967 , no. 64, p. 1792.

173 Dominion, 23 May 1955, p. 10.

$17+$ Committee on Licensing 1960, p. 21.
} 
hours. ${ }^{175}$ In part this may have been in response to pressure from rural publicans. As noted earlier there was a degree of public support for later hours in country areas and the trade advocated such a change to the Minister of Justice in $1961 .{ }^{176}$ Tim Mulcare pointed out another possible reason for the industry's change in attitude after 1960 when a law change allowed some pubs to be exempted from the obligation to provide accommodation. Thereafter it was no longer so commercially important for pubs to be located in business districts to attract custom for the accommodation side; they could be located in suburbs where people actually lived. However this change was of little benefit to the industry with continued early closing, for suburban taverns would attract little afterwork trade. ${ }^{177}$

The change in attitude was reflected in the National Council's submission to the Statues Revision Committee on the 1967 Sale of Liquor Poll Bill. 'Six o'clock closing is an unwarranted fetter on the freedom of the individual citizen,' the Council's lawyer Robin Cooke told the committee. ${ }^{178}$ The council presented the results of an opinion poll showing 73 percent of men and 60 percent of women favoured evening drinking. ${ }^{179}$ However the National Council's public pronouncements on the issue were otherwise guarded and it did not campaign overtly for later closing in $1967 .^{180}$ While the New Zealand Hotel Association ran an active campaign to ensure that people participated in the referendum, it did not express a view as to which way they should vote. ${ }^{181}$ The association was possibly trying to reconcile a variety of views amongst its members. Many were no doubt aware of media reports from Australia of hotels struggling with longer hours and no increase in business. Prowl around the bars of downtown Sydney at night these days and you'll find you can shoot guns in them without hitting a soul,' wrote a columnist in the Auckland Star: ${ }^{182}$ The newspaper's political reporter, Ian Templeton, quoted 'sources in the industry' as saying that 'if 10 p.m. closing is introduced, many

\footnotetext{
175 Stacc, pp. 199-201.

176 New Zealand Licensee, 20 February 1961, p. 29 and Stace, p. 23.

177 Mulcare, 'The political economy of six o'clock closing', p. 13. With six o'clock closing hotels generally needed to be located so as to cater for after-work drinkers.

178 Evening Post, 13 June 1967 , p. 8.

179 Evening Post, 13 June 1967, p. 8.

${ }^{180}$ Sce, for example, the Auckland Star, 9 September 1967, p. 7 and the New Zealand Listener, August 18, 1967, p. 7.

${ }^{181}$ For example, the association placed large advertisements in national daily newspapers on September 11, 19 and 22 . In Dunedin the association put posters in hotels, Otago Daily Times, 4 September 1967, p. 4.

182 Auckland Star, 9 September 1967, p. 7. For more factual reports on reduced pub profits in Australia see Auckland Star, 20 May 1967 , p. 5.
} 
hotels that yield good bar profits at present would become uneconomic'. ${ }^{183}$ Templeton explained why this might be the case. With more leisurely drinking people would drink less. And hotel costs would rise. It is not only a question of greater wage payments for staff, but hotels would have to provide more facilities, room for sit-down drinking. People will not rush to the nearest pub, but will go to one that offers them comfortable drinking conditions.' In other words, without the urgency of early closing, people would have the opportunity to shop around for a pub they liked, rather than settling for whatever hotel was nearest their place of work. It is small wonder that many hotel owners were worried. The Vice President of the Hotel Association warned of higher beer and spirits prices due to the costs of more furniture, lighting and heating. However he did admit that 'most hotel keepers felt that the time had come for a change in hours' ${ }^{184}$ The lack of overt campaigning by the industry in 1967 may therefore reflect division within its ranks, and the Hotel Association campaign to encourage voting was probably a compromise position. The campaign may have helped ensure that those wanting change turned out to vote, thereby contributing to the success of later closing in the referendum. The voter turnout was a healthy 70 percent, compared with 56 percent in $1949 .{ }^{185}$

Although many within the liquor industry had repudiated six o'clock closing, it was still backed by sector unions. The hospitality workers' magazine Flashlight urged members to 'vote for six o'clock closing and preserve your present working conditions'. ${ }^{186}$ The Hotel Workers Union claimed that 'six o'clock closing tends to maintain harmony in the home by getting the adult member of the household home for dinner at a reasonable hour'. ${ }^{187}$ The union's plea on behalf of family values was slightly disingenuous. Its fallback position if voters endorsed later closing was for $11.30 \mathrm{pm}$ closing to allow for two daily shifts. ${ }^{188}$

Another reason the 1960 select committee gave for rejecting evening drinking was that the Churches and the Alliance were 'strongly in favour' of retaining the existing rule on closing hours. ${ }^{189}$ The select committee ignored the fact that the Anglican and Catholic

\footnotetext{
183. Auckland Star, 20 May 1967, p. 5.

18+ Auckland Star, 5 September 1967, p. 5.

185 Figures for 1967 calculated from New Zealand Gazette, no. 64, 1967, p. 1792.

186 Otago Daily Times, 21 September 1967, p. 5.

187 New Zealand Listener, 18 August 1967, p. 7.

18.8 New Zealand Listener, 18 August 1967, p. 7.

189) Committee on Licensing 1960, p. 27.
} 
churches had made no submissions, for it was the attitudes of the traditionally prohibitionist churches that the politicians were most concerned about. ${ }^{190}$ The triennial licensing poll continued to remind them of the importance of the prohibitionist faction, which could still claim the support of nearly one in four New Zealanders in 1957. However there is evidence from a survey of voters conducted after the 1963 election of a possible change in attitude among some prohibitionists, for fully 25 percent of prohibition voters surveyed agreed with extended hours. ${ }^{191}$ While there is no survey evidence to indicate that this was a change from earlier times, the authors of the report found the result surprising. They speculated that, as prohibition became an increasingly unlikely prospect, some of its supporters were prepared to accept any improvement in drinking conditions as a good thing. ${ }^{192}$

In fact many no longer saw early closing as promoting temperance ideals. As was noted in Chapter 3, by the 1960s the Presbyterian Church had given up officially advocating abstinence from alcohol and was rethinking its attitude on issues such as six o'clock closing. In 1966 the Presbyterian committee on liquor problems claimed that with 'rush' drinking under restricted hours, the normal drinker was prone to drink too much too quickly. The committee went on to say that 'extended hours would be a desirable reform' possibly resulting in improved drinking behaviour. ${ }^{193}$ We do not claim that changes in hours will result in spectacular changes in habits, but we are convinced that positive steps towards such improvements are both necessary and desirable. ${ }^{194}$ These statements by the committee perhaps exaggerate how far the church had moved since the 1950 s, for they were objected to by a significant minority of presbyteries and by some church members. ${ }^{195}$ However the change in attitude did much to highlight the growing rift between temperance advocates and traditional prohibitionists. In 1967 the Alliance held as staunchly as ever to the availability ideology, telling the New Zealand Listener it would 'restrict as far as possible opportunities for the sale of liquor'. But its traditional

\footnotetext{
190 Committec on Licensing 1960, Appendix 1.

191 A.II. Ashenden, R.II. Brookes and A.D. Robinson, 'Attitudes towards liquor among New Zealand voters', Political Siene, Volume 18 no 1, March 1966, pp. 1-20. The 1963 survey was actually about voting behaviour in general elections, but included questions on alcohol as these featured in every general election. Respondents were selected from just three urban electorates, so the sample was not nationally representative. Two of the three electorates had significant 'dry' areas, so respondents were possibly more conservative on liquor questions than voters in other areas.

192 Ashenden et al, 'Nttitudes towards liquor among New Zealand voters', p. 7.

193 Dominion, 8 November 1966, p. 6.

194 Otago Daily Tïmes, 20 September 1967, p. 3.

195 Paterson, 'Issues Within the Presbyterian Church, pp. 35-7.
} 
Presbyterian allies rejected the theory, stating there was 'no foundation for the claim that with more time available there is more drinking. ${ }^{196}$ The traditional accord between prohibition and temperance advocates had also broken down in Australia over the issue of six o'clock closing. When a 1965 Royal Commission in Victoria recommended the end of early closing, the president of the Victorian Temperance Alliance resigned when the organisation decided to campaign against change. ${ }^{197}$ After a year of later closing the Alliance secretary admitted that problems associated with liquor had got no worse, and that the end of the swill was a good thing. ${ }^{198}$ According to the Auckland Star, many clergy in Victoria also held such views about the change to ten o'clock closing. ${ }^{199}$

While the Methodist Church still officially backed early closing in 1967, it did so tentatively. Its Temperance Committee told the New Zealand Listener that it members 'were inclined to the view that the possible advantages of extension of drinking hours to $10 \mathrm{pm}$ would not outweigh the possible disadvantages.' ${ }^{201}$ Among the Alliance's traditional allies, only the Salvation Army and the WCTU remained firmly behind six o'clock closing. There was much evidence of changed opinions on the part of clergymen and churchgoers. 'I look for the day when we can be quite open about the pleasure of social drinking,' the Dean of Dunedin told a congregation in St Paul's cathedral. ${ }^{211}$ The Bishop of Auckland was quoted in parliament as wanting 'to do away with the barbarities of the six o'clock swill'. Sir Leslie Munro told Parliament that 'Church denominations have favoured later closing on the evidence of New South Wales and Victoria?. ${ }^{202}$ Hamilton MP Lance Adams-Schneider, a long-time teetotaller and prohibitionist, told the Auckland Star that many churchgoers were ready to support ten o'clock closing to end the swill. He said he had spoken to many churchmen 'traditionally opposed to extending drinking facilities' who would now support later closing. ${ }^{203}$ A reason given by AdamsSchneider for his own change of heart was that the introduction of licensed restaurants, which he had opposed in 1960, had caused no noticeable problems. Indeed the

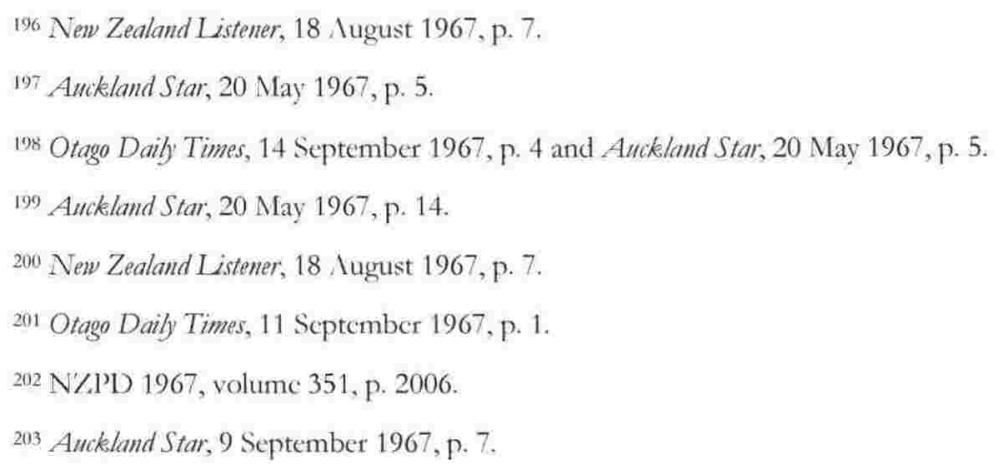


government had introduced a number of reforms with no apparent collapse in civil order, including readmitting barmaids to pubs and extending the deadline for serving drinks in restaurants from eight $\mathrm{pm}$ to $11.30 \mathrm{pm}$. Radio broadcaster Ian Maine noted that the orderly introduction of such changes may have made the public, including temperance advocates, more receptive to further change. ${ }^{214}$

The attitude of Members of Parliament had clearly changed since 1949. The collapse of the prohibition vote by 1966 and the split between temperance and prohibition supporters meant MPs were no longer afraid to speak out. The makeup of parliament had also changed considerably. Prohibitionists were rare and some, such as Adams-Schneider, had modified their views. Indeed, there was criticism both inside and outside parliament that the government was bothering with a referendum at all, given the support among MPs for change. A week before the referendum, Prime Minister Keith Holyoake claimed that four out of five MPs supported later closing. ${ }^{2015}$ 'There are various anomalies and difficulties in our liquor laws,' the Minister of Justice told Parliament when introducing the Sale of Liquor Poll Bill, 'and many have their roots in six o'clock closing'. Several other MPs spoke in favour of change and none against. ${ }^{206}$

MPs were not so bold a few years earlier. In 1962 Cabinet reversed a decision to hold a referendum on opening hours and did not finally agree to a referendum until $1966{ }^{207}$ The idea that the government could simply legislate a change, as it did with other issues both important and minor, was of course never seriously considered. Even when the government did finally produce a draft Sale of Liquor Poll Bill, it was extremely conservative. The availability theory and cult of domesticity that so influenced the 1949 referendum result still held sway with the older generation that dominated Cabinet. The draft bill therefore included provision for a dinner break, reflecting the views of the 1960 select committee. ${ }^{208}$ By 1967, this proposal pleased no-one. The Alliance and others pointed out that a meal break had been tried in New South Wales but dumped after eight

\footnotetext{
204 Nen Zealand Listener, 18 August 1967, p. 7.

205 Auckland Star, 19 September 1967, p. 4.

206 N/PD 1967 volume 351, pp. 1375-2029.

207 Stace, p. 200-202.

208 Committee on Licensing 1960, p. 28.
} 
years, as it led to two swills instead of one. The National Council cited an opinion poll showing 63 percent of respondents opposed a meal break. ${ }^{201}$

Furthermore, the National Council was opposed to any formulation of the wording for the late closing option that was too precise, as had been the case in 1949. It proposed instead that the wording should be left open-ended to avoid tying parliament's hands and to allow for possible regional variation in hours. Parliament accepted the general thrust of the Council's proposal, settling on the wording 'I favour later closing, the actual hours of sale to be decided according to local conditions. ${ }^{210}$ A month later the government announced its intention, if the referendum was passed, to introduce ten o'clock closing but to allow for earlier closing in parts of the country. ${ }^{211}$

The referendum campaign was lively, mainly thanks to the newspapers. The Otago Daily Times editorialised in favour of later closing as early as February 1967. ${ }^{212}$ Later in the year the paper commissioned an Australian correspondent to report on the impact of ten o'clock closing in Victoria, introduced in February 1966. The Auckland Star also ran an extensive feature on the Victorian situation. Both papers reported the effects to be almost universally positive. The Otago Daily Times correspondent attested to 'improved facilities, more provision for meals, a noticeable increase in mixed drinking, a swing from 'stand-up' to 'sit-down' drinking, and the development of entertainment'. ${ }^{213}$ The paper was particularly active in the weeks before the referendum, running regular stories featuring advocates or opponents of early closing.

Despite the lively newspaper coverage there was little organised campaigning in favour of later closing. A group called The Campaign for Civilised Drinking made minimal impact, at least in terms of newspaper publicity. ${ }^{214}$ Another organisation called the New Zealand Late Closing Committee placed a single advertisement in the Auckland Star. ${ }^{215}$ However a Hawkes Bay farmer, Harry Somes, was so keen on change that he took a leaf out of the

\footnotetext{
209 Evening Post, 13 June 1967, p. 8, and N'LPD 1967, volume 351, p. 1375.

210 Sale of liquor Poll Act, New Zealand Statutes 1967 , p. 65 . The other option in the ballot was 'I favour 6 p.m. closing as at present'.

211 Otago Daily Times, 26 August 1967, p. 1 and 31 August, p. 1.

212 Otago Daily Times, 4 Ficbruary 1967, p. 4.

213 Otago Daily. Times, 14 September 1967, p. 4.

$21+$ 'The campaign did not appear to be mentioned on the Alukland Star at all, and received only one brief reference in the Otago Daily Times, 18 September 1967, p. 4.

215 Anckland Star, 18 September 1967, p. 7.
} 
Alliance's book from the heyday of temperance campaigning and commissioned an overseas speaker. Adelaide lawyer Keith Sangster, who ran the one-man royal commission that recommended later closing in South Australia, was invited to address service clubs. ${ }^{216}$ He told a Hastings meeting that opposition to later closing presented to his commission had come from people who were totally opposed to alcohol. 'Their arguments were that all alcohol is evil, that all restrictions are good and any suggested extension or any other facility automatically bad. ${ }^{217}$

Some New Zealand newspaper correspondents on the issue were also against alcohol, as shown by such phrases such as 'an extension of evil' and 'better the devil you know'. ${ }^{218}$ However opponents of change also provided other arguments, with several claiming that later hours would mean more drinking and would disrupt family life, particularly with the lack of suburban hotels in New Zealand. Extended hours would mean increased loneliness for the suburban housewife', Mrs C.M. Purdue told the Auckland Star. ${ }^{219}$ A newspaper correspondent wrote of 'married men swallowing their evening meal and rushing back to squander the household allowance in a four-hour swill. ${ }^{22}$ Another writer showed little sympathy for such views. "The chorus of protest against extended hours comes from wives who publicly admit the shameful fact that only laws can keep their husbands out of the pubs. ${ }^{, 221}$ Opinion polls did indeed indicate that women were considerably less likely than men to support later closing.222

The Alliance placed a number of newspaper advertisements with the catch-line 'Stick to six'. ${ }^{223}$ But much of its campaign was waged through the medium of unsolicited mail; the Dean of Dunedin claimed he had been bombarded with propaganda for early closing. ${ }^{224}$

\footnotetext{
216 Auckland Star, 5 September 1967, p. 5. It is unclear how much of Sangster's trip was funded by Somes. 'I the Otago Daily Times simply says Somes invited him to New Zealand, 5 September 1967, p. 3.

217 Otago Daily Times, 5 September 1967, p. 3. The South Nustralian government had accepted the Commission's recommendations, but the bill for later closing had not yet passed. New Kealand therefore narrowly beat it to end the swill.

218 Sec, for example, Otago Daily Times, 1 September 1967 and 14 Scptember, p. 4.

219 Auckland Star, 4 September 1967, p. 7.

220 Otago Daiby Times, 20 September 1967, p. 4.

221 Otago Daily Times, 14 September 1967, p. 4.

222 For example, a survey by the mathematics department of Christchurch T'eachers College found that $54 \%$ of women favoured later closing compared with $75 \%$ of men, Anckland Star, 19 September 1967, p. 4.

223 See, for example, Auckland Star, 21 September, p. 21 and 22 September, p. 5, and Otago Daily Times, 19 September, p. 6 and 22 September, p. 2.

$22+$ Otago Daiby Times, 11 September 1967, p. 1.
} 
A few weeks before the referendum the Alliance announced it was launching a giveaway newspaper, The Six O'llock Edition, aimed mainly at showing the detrimental effects of later closing in Australia. Its contents were somewhat controversial. The Otago Daily Times referred an article alleging increased teenage drinking in Melbourne to a senior police officer for comment. The officer said the article was inaccurate. ${ }^{225}$ A researcher in 1970 investigated Alliance claims that later closing had led to increased drinking in Australia. He found the claims to be based on highly questionable and distorted evidence. ${ }^{226} \mathrm{~A}$ newspaper correspondent characterised The Six O'clock Edition as propaganda for prohibition rather than for early closing. 'It is possible to argue coherently for prohibition; it is difficult to argue for a set of hours which are a direct inducement to making drinking a work-time rather than a spare time activity. ${ }^{227}$

Despite such criticisms, the Alliance campaign appears to have been effective. The result in the 23 September referendum was considerably closer than might be expected from opinion polls. Despite the 70 percent turnout, only 44 percent of registered voters supported later closing. ${ }^{228}$ However the two to one majority among those who did vote was more than enough for the government, which passed legislation within weeks. The swill officially ended on Monday 9 October 1967, just seven weeks short of its fiftieth anniversary.

Six o'clock closing was introduced somewhat unwillingly by MPs as a wartime measure in 1917 and may never have happened without the report of the prohibitionist-dominated National Efficiency Board. It was made permanent in 1918 by a majority of one. Once instituted, early closing proved difficult to undo despite the fact that the law was widely evaded and gave rise to an unpleasant institution that became known as the six o'clock swill. With regular licensing polls showing significant residual support for prohibition, MPs were nervous of liberalising drinking laws. Even when the 1945 royal commission recommended allowing the evening opening of public bars the government was unwilling

\footnotetext{
225 Otago Daily Times, 20 September, 1967, p. 5.

226 Biggs, 'Political and Social Implications of Later Closing'. Biggs implies that the Alliance deliberately distorted the information that formed the basis for its claims.

227 Otago Daily Times, 14 September 1967, p. 4.

228 New Zealand Gazette, no. 64, 1967, p. 1792. Another proposal put to voters on the same day, that the parliamentary term should increase to four years, was overwhelmingly rejected. There was almost no publicity or discussion in the press on this issue
} 
to act without the endorsement of a referendum - a move that probably reflected the opposition of senior Ministers to later closing.

The 1949 referendum overwhelmingly endorsed six o'clock closing, assisted by support for the status quo by all major pressure groups. The 1949 result also reflected the ideology of domesticity and the entrenchment of the availability theory. Many feared that the prospect of later drinking would tempt men to forgo their evening meal and neglect their families. Even supporters of evening drinking often advocated an enforced evening break to ensure that men went home for dinner. The inflexible wording of the referendum question provided no assurance to this latter group that such concerns would be met under the ten o'clock closing option. The emphatic result in 1949 made politicians even more wary of acting to eliminate the swill. By the 1960 s the government remained unwilling to act without the endorsement of a further referendum despite an apparent groundswell of support for change. This endorsement came in October 1967 when the electorate voted decisively to end six o'clock closing.

A number of reasons have been suggested here for the change in public attitudes in the 18 years since 1949. Change in Australia provided a positive example, as did a slight liberalisation of New Zealand drinking laws. Moderates in the nonconformist churches started to realise that the swill was incompatible with temperance, resulting in a split with hardline prohibitionists. Even the formerly prohibitionist Presbyterian Church dropped its traditional adherence to restrictionist thinking, arguing there was no evidence that later closing led to more drinking. MPs no longer feared the prohibition lobby and collaborated with the liquor industry to ensure the referendum was worded in a way that facilitated an end to the swill. The hotel industry ran a campaign to ensure people went to the polls. The press was considerably more active than in the 1940 s.

Other factors were also relevant. As even Bollinger acknowledged, drinking conditions had improved by 1967 largely due to the activities of the LLC. ${ }^{229}$ Immigration revived in the 1950 s and $1960 \mathrm{~s}$, bringing new settlers with different attitudes. People travelled more and were exposed to the drinking customs of other countries. The introduction of television from 1960 may also have affected the public's view of later drinking. In the popular television soap opera Coronation Street, the local tavern was seen to be a convivial

229 Bollinger, 1967, pp. xi and 3 . 
evening meeting place, and the 'Rovers Return' was mentioned on more than one occasion during the 1967 debate. $^{230}$

The swill was not all bad. McLauchlan remembers with some nostalgia the social mixing that lack of choice imposed on drinkers, the male camaraderie, and the fun of evading the restrictive laws. $^{231}$ But few will rue its passing. In early 1967 a British journalist photographed the interior of the Wairaki Hotel at six pm, a photograph reproduced in the Auckland Star. 'The scene,' he said, 'is reminiscent of the days of the gold rush in the American Wild West.' ${ }^{232}$ Few will regret that those Wild West days are over.

230 Sce, for cxample, Otago Daily Times, 15 and 16 September 1967, p. 4.

231 Mclauchlan, Story of Beer; pp. 137-8.

232 Auckland Star, 20 May, 1967 , p. 5. 


\section{A CENTURY OF EXPERIMENTS}

As was outlined in the introduction, a central question to be addressed by this thesis is whether restricting access to alcohol led to lower average alcohol consumption in New Zealand. New Zealand is thus being used as a test case for the public health approach to liquor control that is sometimes dubbed 'the availability theory'. The theory makes two main claims: firstly, that the amount of harm done by alcohol in a society is directly related to the amount of alcohol consumed per person; secondly, that limiting the availability of alcohol can restrict alcohol consumption. As was seen in the introductory chapter, some dispute aspects of the first claim. ${ }^{1}$ However the main purpose of this chapter is to test the second claim - that reducing the availability of alcohol reduces alcohol consumption and increasing availability increases consumption. This claim will be tested using examples of 'experiments' from New Zealand history in which policy changes led to rapid changes in availability of liquor. This chapter first discusses recent empirical evidence cited in support of the availability theory. It then looks at the effect of sudden changes in 'economic availability' through the large increases in liquor taxes instituted in 1921 and 1958.

The rest of the chapter is largely devoted to assessing the effect of changes in the physical availability of liquor, starting with the effects of the rapid reduction in outlet numbers after 1894. Did a halving of per capita outlet numbers in 16 years lead to the big reductions in drinking and drunkenness that advocates of these restrictions hoped for? It next examines the effect of the drastic reduction in outlet opening hours through the introduction of six o'clock closing in 1917 and the results of the reversal of this reform in 1967. Did sudden and significant changes in legal drinking hours have the expected effect on consumption? The next test of the availability theory comes from the significant loosening of restrictions on outlet numbers after 1976 and especially after 1989. Were fears that these reforms would lead to increased drinking realised? Finally it looks at some

' Examples cited include I Ianson, Preventing Akohol Abuse and Roche, The shifting sands of alcohol prevention'. 
other historical New Zealand evidence relating to the theory, including changes to the drinking age.

\section{Empirical Evidence and 'Natural Experiments'}

In a 2004 British report, the Academy of Medical Sciences concluded that 'the evidence shows that a lower average alcohol consumption of the population is likely to lead to a lower burden of alcohol-associated problems'.2 This focus on average consumption explains why the claimed relationship between the availability and consumption of alcohol is so essential to restrictionist thinking. Availability restrictions, if effective, will mean fewer alcohol-related problems. But, as discussed in Chapter 1, the popularisation of the disease concept of alcoholism after the Second World War cast doubt on the validity of this approach. It appeared quite feasible that average consumption could be reduced while leaving untouched the consumption of the small and fixed minority who regularly abused alcohol. By the 1970 s a variety of responses were available to this objection. Numerous studies had found a consistent correlation between movements in the rate of alcohol consumption in a population and death rates from alcoholic cirrhosis of the liver. ${ }^{3}$ It seemed that when the population of a country started to drink more, those already consuming to excess increased their drinking still further - sometimes to fatal levels. ${ }^{4}$ The single distribution model pioneered in the $1950 \mathrm{~s}$ by French mathematician Sully Ledermann supplemented the evidence on liver cirrhosis. Ledermann drew on survey data on drinking volumes that showed there was a single rather than a bimodal distribution of drinkers in any population - in other words there was no sharp distinction between moderate and heavy drinkers. Furthermore, any increase in average alcohol consumption appeared to be spread fairly evenly across the spectrum of drinkers, leading to an increase in the numbers crossing a threshold that might delineate moderate from heavy drinking. ${ }^{5}$ It was also recognised that the majority of alcohol-related problems seemed to arise for people with supposedly moderate levels of consumption - the so-

\footnotetext{
2 'The Icademy of Medical Sciences, Calling Time: The Nation's Drinking as a Major Health Issure, London, 2004, p. 33.

3 Schmidt, 'Cirrhosis and Ncohol Consumption', pp. 15-47.

4 A time series study of New 'Lealand and other English-speaking countries is provided by William Kerr, Kaye Middleton Fillmore and Paul Marvy, 'Beverage-specific alcohol consumption and cirrhosis mortality in a group of Englishspeaking beer-drinking countrics', Addiction, March 2000, vol 95, no. 3, pp. 339-347.

5 I leather and Robertson, Problem Drinking, pp. 87-90.
} 
called 'preventive paradox'. . This was seen to provide strong evidence in favour of treating the damage caused by alcohol as a public health issue rather than as a problem affecting a small minority of heavy drinkers labelled 'alcoholics'. Public health theorists proposed a model of social contagion to explain how the drinking habits of members of a population might be causally inter-related. They argued that because drinking is a social activity people tend to influence each other in their drinking habits - the custom of purchasing drinks in rounds being an obvious example. Therefore if some start to drink more, perhaps because of a rise in income, then those they drink with may also increase their consumption. A snowball effect then ensues, with the changed drinking habits spreading throughout the population. ${ }^{8}$

Finding empirical evidence for a link between availability and consumption proved problematic. There was little disagreement that changes in economic availability - the affordability of liquor - had a direct effect on consumption, even if the size of this effect was disputed." However the claimed relationship between consumption and physical availability such as outlet density and hours of sale appeared to be as less well supported. As with many theories in the social sciences, those that make generalisations about the drinking behaviour of large populations do not readily lend themselves to testing through controlled experiments which include random assignment and control groups. As an alternative, researchers commonly use observational studies supplemented by statistical techniques that try to rule out alternative explanations. In the case of the availability theory, researchers looked for correlations between availability and consumption in geographical areas or across time. The problem with such an approach is that it is hard to control for all plausible causal factors. A report published by WHO in 1985 concluded the following: 'Statistical analyses of relationships between alcohol consumption, alcoholrelated problems and various measures of the physical availability of alcoholic beverages (for example, density of different types of sales outlets) have produced widely varying

6 See, for example, Tim Stockwell, 'Do controls on the availability of alcohol reduce alcohol problems?' in Stockwell, ed., An Examination of the Appropriateness and Effrcaly of Liquor Licensing Laus Across Australia, Curtin University: Perth, 1995, pp. 125-7. The phenomenon is sometimes labelled a paradox because it implies that better overall health outcomes will be achicved by preventive measures targeting those whose drinking levels appear to put them only moderately at risk rather than targeting those whose drinking appears to be at the high-risk end of the spectrum. This is because there are far more moderate-risk drinkers.

7 The Academy of Medical Sciences, Calling Time, pp. 7-8, 19-24 provides a good summary of the arguments.

8 Schmidt, 'Cirrhosis and Ilcohol Consumption', pp. 35-38 and Single, "The availability theory of alcohol-related problems', p. 328.

"See, for example, Trolldal, 'Availability and sale of alcohol in four Canadian provinces'. 
results. This is generally attributed to differences in research design, differences in selection and definition of variables, the complexity of the question and/or the shortcomings of available methodologies. ${ }^{10}$ Some literature reviews found that the failure to separate physical availability from economic factors such as price was a common flaw in a number of studies attempting to link availability and consumption. ${ }^{11}$ An even more serious problem was the confusion over the direction of causation. In the words of one report, 'does greater availability lead to greater consumption or does greater consumption, itself a function of a variety of socio-economic factors, lead to a demand for greater availability? ${ }^{12}$

Lack of adequate data on alcohol consumption affected American studies attempting to show that higher outlet density led to more drinking. ${ }^{13}$ For this reason they commonly used indirect measures of alcohol consumption and abuse, such as the level of violent crime in a district, when testing the relationship between outlet density and consumption. Because alcohol is considered to be frequently associated with social problems such as violence, such studies were based on the assumption that greater outlet density will lead to greater consumption which will in turn lead to a greater incidence of assault and related crime. ${ }^{14}$ While these studies often found the expected positive correlation, 'others have found that alcohol outlet density adds little to the explanatory power of models comprised of socio-demographic variables'. ${ }^{15}$ In other words poor areas may have both more liquor outlets and more violence, but the two factors are not necessarily causally related. ${ }^{16}$ Furthermore, the relationship between drinking and crime proved in a variety of studies to be a highly complex one. ${ }^{17}$

10 Susan Farrell, Review of National Policy Measures to Prevent Akobol-Related Problems, Geneva, 1985, p. 24.

11 Paul Gruenewald, 'Alcohol problems and the control of availability: theoretical and empirical issues', in Michael I lilton and Gregory Bloss, eds., Economics and the Prevention of Alcobol-Related Problems, Washington DC, 1991, p. 70, and Nieuwenhuysen, 'Liquor control policy and alcohol availability-consumption relationships', p. 266.

12 Quoted by Nieuwenhuysen, p. 266. See also Gruenewald, p. 71 and Single, "I he availability theory of alcohol-related problems, pp. 339-340.

13 See, for example, Stockwell, Do controls on the availability of alcohol reduce alcohol problems?', p. 134.

14 For an outline of this chain of reasoning see D.M. Gorman, 'Nlcohol Ivailability and Domestic Violence', American Journal of Drig and Alcohol Abuse, November 1998, accessed at www.findarticlesicom on 28 Junc 2004.

15 Gorman et al, 'Alcohol Availability and Domestic Violence', p. 1.

${ }_{16}$ It could, for example, be speculated that districts with a high density of takeaway food outlets are likely to have aboveaverage rates of violent crime, although there is unlikely to be a causal relationship between these factors.

${ }^{17}$ James Collins Jr, ed., Drinking and Crime, London, 1982. 
One response to these problems from public health advocates was to propose that availability was not one-dimensional but encompassed a whole range of factors acting in concert. In 1988 Eric Single defined 'availability' as referring to 'both physical accessibility (e.g., number of outlets and purchase restrictions) and economic accessibility (e.g., price and affordability)', a distinction that has already been noted. However, he also included among those control measures affecting availability 'general economic regulations that affect all commodities in the market, not just those measures that treat alcoholic beverages as a special commodity. ${ }^{18}$ In other words the definition of alcohol availability could include a huge range of economic factors; a rise in the cost of essentials such as electricity could plausibly affect demand for alcohol through its influence on discretionary expenditure. Economist Paul Gruenewald noted that there are also subjective aspects to availability such as how far people are prepared to travel to buy liquor, and their changing preferences. $^{19}$ Defining availability as almost anything that might conceivably affect demand for alcohol made the theory irrefutable and therefore untestable. It also rendered it almost worthless as a guide to what sorts of policies might best reduce alcohol abuse, as was shown in 1988 when ALAC opposed any law changes that might increase the number of liquor outlets." ALAC cited evidence of a link between availability and consumption based on a definition of availability that included such diverse factors as price, outlet density and the drinking age. The fact that at least some of the various parameters might conceivably affect consumption was used to argue against changing any of them.

A possible way of ruling out plausible alternative explanations and avoiding uncertainty about the direction of causation is to utilise the results of 'natural experiments', sometimes called 'quasi-experiments' ${ }^{21}$. These are situations in which factors independent of the researcher help rule out alternative causal possibilities; for example, identical twins separated at birth provide a natural control for genetic factors when assessing the impact of the environment on outcomes. ${ }^{22}$ A classic natural experiment was recorded by John

\footnotetext{
is Single, 'The availability theory of alcohol-related problems', p. 325.

19 Gruenewald, 'Alcohol problems and the control of availability', pp. 64-66.

20 AL.AC, 'The Availability Issue', Sale of Liquor Act 1988: ALAC Update Number 2, Wellington, 1988.

${ }_{21}^{11}$ Bruce Meyer, Natural and Quasi-Txperiments in Ficonomics', Journal of Business and Economic Statistics, volume 13, no. 2, April 1994, pp. 151-161.

22 Stephen Jay Gould, The Mismeasure of Man, New York, 1981, pp. 234-5.
} 
Snow during the 1853-4 London cholera epidemic that enabled him to test his theory that the disease was transmitted by water rather than air. ${ }^{23}$

Two competing water companies had laid pipes up the same streets in several south London districts. In the 1848-49 epidemic, both companies had drawn upon water from the River Thames that had been contaminated by sewage. By 1853 , one company (Southwark and Vauxhall) still supplied contaminated water, while the other company (Lambeth) had moved its intake source upstream to a fairly clean section of the river. When Snow learned of this change in the water supply, he realised that this arrangement constituted a superb natural experiment. ${ }^{24}$

By analysing the results of this experiment Snow found that those households supplied with the cleaner water had substantially lower rates of cholera mortality than those still supplied with contaminated water, providing an important confirmation for his theory. ${ }^{25}$ A significant and rapid change, such as the implementation of a new government policy, can also constitute a natural experiment, with the situation before and after the change being compared. ${ }^{26}$ For example the introduction of Euro notes and coins from 1 January 2002 enabled economists to test the theory of 'money illusion' - that consumers may respond irrationally to nominal changes in the value of money. A study found confirmation for the theory when Italian church collections increased once the Euro replaced the Lira. ${ }^{27}$ In another research project the inability of a Canadian town to get television reception allowed for investigation of the social and cognitive effects of television by collecting data before and after a new transmitter was installed in $1973 .^{28}$

Tim Stockwell has noted that substantial or sudden changes in the availability of alcohol may constitute a form of 'natural experiment' through which to test the availability theory. Such an opportunity may arise 'through the sudden relaxing or tightening of control

${ }^{23}$ John Snow, 'On the Mode of Communication of Cholera', 1855, published online by UCLA School of Public Health, http://uww.ph.ucla.edu/epi/snow/snowbook3.htiml, accessed 14 June 2005.

${ }^{24}$ Howard Brody et al, 'Map-making and myth-making in Broad Street: the Iondon cholera epidemic, 1854', The Lancet, 1 July 2000 , v. 356 , issue 9223 , p. 65 .

25 Brody et al, Map-making and myth-making', p. 65.

${ }^{26}$ Sandra Mathison, ed., Enyclopedia of Evaluation, 'T housand Oaks, California, 2005, p. 271.

27 Edmund Cannon and Giam Pictro Cipriani, 'Euro-illusion: A Natural Experiment', Discussion Paper 03/556, Department of Economics, University of Bristol, December 2003, available at: http:/www.efm.bris.ac.uk/cconomics/working papers/pdffilcs/dp03556.pdf, accessed 15 June 2005.

28 Tannis MacBeth Williams, ed., The Impat of Television: A Natural Experiment in Three Communities, London, 1986. The reception problems were a geographical oddity and the town was otherwise 'normal' with regards to factors such as proximity to other towns. 
through legislative means' ${ }^{29}$ If a policy intervention leads to a rapid increase or decrease in liquor availability it can then be assessed whether or not drinking increased or decreased as predicted by the theory. The results of a number of Scandinavian liquor experiments were usefully summarised in a recent publication edited by Robin Room. ${ }^{30}$ While some of the experiments discussed were narrowly focussed, or of a short-term nature such as strikes, others were more far-reaching. For example Swedish alcohol rationing ended in 1955, resulting in an apparent increase in consumption by heavy drinkers. ${ }^{31}$ But perhaps the most striking Nordic liquor experiment occurred in Finland in 1969.

Finland maintained strict controls on alcohol following a period of prohibition from 1919 to 1932. Liquor was sold only through a tiny number of state-owned liquor stores and in licensed restaurants; there were no bars. Under such tight restrictions drinking was an occasional rather than a regular activity, while many abstained altogether. When Finns did drink, it tended to be to the point of intoxication. ${ }^{32}$ In the 1960 s the government considered that Finns might be less inclined to binge drink if they drank beer rather than spirits and if drinking became more a part of everyday life. It therefore allowed beer to be sold in most food stores and cafes and increased the number of state liquor stores and licensed restaurants. ${ }^{33}$ The result was a 46 percent increase in liquor consumption in one year, an increase that was sustained over time. ${ }^{34}$ Alcohol-related mortality increased during the decade after the reform, as did arrests for drunkenness. ${ }^{35}$ The Finnish experiment has been regularly cited since the early 1970 s as evidence of the effectiveness of availability restrictions. ${ }^{36}$ "The Finnish case provides a clear example of what can

29 'Tim Stockwell, Do controls on the availability of alcohol reduce alcohol problems?' in Stockwell, ed., An examination of the appropriateness and efficagy of liquor licensing laws across Austratia, Perth, 1995, p. 130.

30 Robin Room, ed., The Effects of Nordic Alcobol Policies: What Happens to Drinking and Harm When Controls Change?, Helsinki, 2002 .

31 Pia Makela, Ingeborg Rossow and Kalle Tryggvesson, Who drinks more and less when policies change? - The evidence from 50 ycars of Nordic studics', in Room, ed., The Effects of Nordic Alcohol Policies, p. 19.

32 This brief summary is based on US Library of Congress Country Studies, 'I"inland - Services for Substance Abusers', available at countrystudies.us/finland/71.htm, accessed 29 June 2004, Miska Rantanen Nearly 140 years of Finnish alcohol regulation, in Helsingin Sanomat: International Edition, 26 August 2003, available at www2.helsinginsanomat.fi/Iinglish/archive/news.asprid=2003082611:13, accessed 17 Ipril 2004, and Fisa Österberg, 'Finland', in Blocker et al, Alcohol and Temperance in Modern History: an International Engyclopedia, pp. 240-2.

33 Iidwards and Grant, eds., Aliobolism, p. 135, and Makela et al, 'Who drinks more and less when policies change?', p. 22.

3+ Schmidt, 'Cirrhosis', p. 40.

35 Makcla et al, 'Who drinks more and less when policies change?' pp. 23-4 and Farrell, Review of National Poligy Measures to Prevent Alcohol-Related Problems, pp. 13-14.

36 Babor et al, Alcobol: No Ordinary Commodity, p. 125, and . Icademy of Medical Sciences, Calling Time, p. 28 are two recent examples. 
happen to the level of consumption when alcoholic beverages are made more available,' warned one researcher in 1977. ${ }^{37}$ Although the Finnish economy was flourishing in 1968 and alcohol consumption was already on the rise before the changes, the sheer magnitude of the increase in consumption makes for a compelling case. ${ }^{38}$

The advantage of testing the availability theory through these sorts of sudden changes is that it largely eliminates the direction of causation problem, for it is clear that the change in availability preceded rather than followed any change in consumption. However, because of the lack of a control group it is debatable whether they constitute the sort of rigorous natural experiment conducted by John Snow. Perhaps an alternative term such as 'historical experiment' better describes the case. So are the results of the Finnish experiment confirmed by other experiments in liquor availability? Have dramatic changes in availability in other countries produced the changes in liquor consumption that would be expected under the availability theory?

As has been seen in previous chapters, New Zealand provides several examples of changes in liquor control policy that have led to dramatic changes in availability over relatively short periods of time. At the start of the twentieth century British statesman Herbert Asquith famously described the country as 'a laboratory in which political and social experiments are every day made for the information and instruction of the older countries of the world'. ${ }^{39}$ His vision of New Zealand as a social laboratory became part of the country's national mythology. Asquith was perhaps partly referring to the country's isolation, which enabled social experiments to be carried out relatively free from distorting external influences, as in a scientific laboratory. But he was also referring to radical innovations, or the enthusiastic adoption of ideas developed elsewhere, in areas such as industrial relations, electoral reform, education, social welfare and workplace health and safety. ${ }^{40}$ Some of these innovations were the subject of William Pember Reeves' State Experiments in Australia and New Zealand published in 1902. ${ }^{41}$ Reeves' work contained chapters on labour laws and old age pensions, but also included a chapter on a subject that modern readers may not immediately associate with New Zealand's innovative social

37. David Robinson, 'Factors Influcncing Alcohol Consumption' in Edwards and Grant, Alcoholism, p. 73.

38 Robin Room, Anders Romelsjo and Pia Makcla, 'Impacts of alcohol policy: the Nordic experience', in Room ed., The Effects of Nordic Alcohol Policies, p. 167. See also Schmidt, 'Cirrhosis', p. 40.

39 Quoted in Sinclair, A History of Newn Zealand, p. 195.

40) Hamer, New Zealand L iberals, pp. 62-64 and Sinclair, History of New Zealand, pp. 179-196.

${ }^{+1}$ William Pember Recves, State Experiments in Australia and New Zealand, two volumes, Edinburgh, 1902. 
experiments - the liquor laws. The chapter was primarily about experiments in local option, noting that New Zealand initially lagged some Australian colonies in its experiments in liquor control but then 'after its fashion, went some distance ahead of its neighbours'. ${ }^{42}$ While the Australian local option laws were 'partial half-hearted affairs from which not much could be expected', the New Zealand experiment was 'worth watching. ${ }^{43}$ As was seen in Chapter 4, New Zealand's experiment in local option had dramatic results, with the closure of hundreds of hotels. Other restrictions soon followed. In 1910 the legal drinking age was raised from 18 to 21 and in December 1917 the government outlawed most liquor sales after six pm. These restrictions remained in place until the 1960s.

Later changes radically increased rather than decreased the availability of liquor. After 1967 alcohol could be legally sold as late as ten pm following a referendum on bar opening hours. From 1977 most sports clubs could acquire liquor licences and restaurants could obtain permits allowing their customers to bring their own alcohol. There is some debate as to the extent to which these changes increased the availability of alcohol, for many sports clubs were known to have been selling liquor illegally for many years before the changes. ${ }^{44}$ However there is no dispute that liquor availability increased dramatically in the 1990s following a major overhaul of liquor licensing. The result was a 64 percent increase in the number of licensed liquor outlets per capita within five years. ${ }^{45}$ Finally, in December 1999 the legal minimum age for the purchase of alcohol was lowered from 20 to $18 .^{46}$ New Zealand governments have also instituted a number of changes in the level of taxation levied on alcohol, thereby affecting the price of liquor. Two of these changes were significant ones in which liquor taxes were doubled overnight. In 1921 and 1958 the per volume taxes levied on the producers and importers of beer and spirits were increased by 100 percent. In 1921 the import duties on wine were also increased. ${ }^{47}$

\footnotetext{
42 Recves, State Experiments, volume 2, p. 309.

${ }^{43}$ Reeves, State Experiments, volume 2, p. 323.

H Sce, for example, M. IC, 'The Ivailability Issue'.

${ }^{5}$ Calculated from figures supplies by the I iquor licensing . Luthority.

* Sale of Liquor Amendment Act 1999, Scction 83.

47 Finance Act, New Zealand Statutes 1917, pp. 40-1, 56, Finance Act (No. 2), Nem Zealand Statutes 1921-22, pp. 255-6, Customs Amendment Ict, New Zealand Statutes 1921-22, pp. 167-8, A.H. Nordmeyer, Budget 1958, Tinancial Statement', AJIIR 1958, B.6, p. 32.
} 
Because of these radical shifts in the availability of alcohol, New Zealand can be seen as a test case for the availability theory. The central question to be explored is therefore whether significant changes in outlet numbers and hours of sale and big increases in liquor taxes led to the reductions or increases in alcohol consumption that the availability theory would predict. Good long-term data on alcohol consumption is needed to test the claim that reducing the availability of alcohol will reduce its consumption. In the case of New Zealand such data is readily available because taxes were imposed on both imported and locally produced liquor from the $1840 \mathrm{~s}^{48}$ The resulting figures on per capita consumption of beer, wine and spirits were reported in the official yearbooks. Like any data source, that on alcohol consumption has its weaknesses. The information collected by the Customs Department was 'alcohol available for consumption' - the amount of liquor imported or manufactured for local consumption each year. ${ }^{49}$ It is therefore not the amount of alcohol actually drunk, some of which will have been consumed in subsequent years, particularly wine and spirits. The figures largely measure the response of importers and producers to perceived changes in demand, with an over or undersupply leading to adjustments depending on the amount of stock on hand. In late 1917, for example, breweries cut back production in the expectation that six o'clock closing would lead to lower demand. ${ }^{5 \prime \prime}$ This delay effect aside, the figures should provide a reasonable estimate of the amount of liquor legally bought and consumed each year. One researcher has noted that the data is widely used internationally to measure and compare consumption and trends between countries'. ${ }^{51}$ However the official statistics do not capture illegal activities such as the sale of liquor whose manufacture or importation has not been declared to Customs, or legal alternatives such as home brewing and duty free purchases. ${ }^{52}$ The figures will therefore always underestimate the true level of consumption. This is not a problem for researchers providing there are few major variations in unrecorded production and importation over time. In practice activities such as home manufacture are likely to be more prominent during times of severe economic downturn such as the early 1930 s, so the falls in officially measured alcohol consumption during these periods

\footnotetext{
48 NZOYB 1990, pp. 590, 661 and David McGill, The Guardians at the Gate: The Histony of the New Zealand Customs Department, Wellington, 1991, Chapters 1-4 and 7.

49 Sandy Brinsdon, Alcohol Data: New Zealand Data Sources Relating to Aliobol, Wellington, 1998, pp. 3-5, Statistics New Kcaland, "Technical Notes' in Alobol and Tobacio Available for Consumption (Year Ended December 2004), Wcllington, 2005.

50 'Financial Statement of the Minister of Finance', AJHR, 1918, B.6, p. v.

51 Brinsdon, Alcobol Data, p. 5.

52. Nthough overseas trips have become increasingly common it has been assumed that duty free purchases make up a small minority of total alcohol consumed, with spirits consumption being the main measure affected.
} 
are likely to overstate the true case. In the 1930 s the government waged an on-going battle over the illegal distillation of whiskey in the far south..$^{53}$ Home brewing and winemaking undoubtedly also increased. Only recent estimates of home consumption are available, from surveys of drinking habits conducted in 1995 and 2000. These showed that home production accounted for three to four percent of total alcohol available for consumption in those years. ${ }^{54}$ It is unclear how representative these figures are of earlier times, but given the regular increases in excise taxes since the late $1970 \mathrm{~s}$, the legalisation of home distillation in 1996, and the spread of specialist home brewing outlets, there is no reason to suppose the extent of home production was any higher in earlier decades. Eldred-Grigg claimed that the reliability of official consumption figures increased considerably after the 1880 s, as the economy improved, enforcement of excise taxes and the laws against smuggling and distilling became more effective, and mass-produced beer became cheap enough to discourage home production. ${ }^{55}$

The only aspect of the availability theory being tested in the following analysis is the proposition that reducing the availability of alcohol will lead to a reduction in average alcohol consumption. This thesis is not testing the claim that the incidence of alcoholrelated problems tends to rise and fall with consumption. However, reference is commonly made in the literature to drunkenness convictions. For example the Alliance regularly claimed that the introduction of six o'clock closing in 1917 had led to a decline in convictions for drunkenness. ${ }^{56}$ The common use of drunkenness statistics was due to their ready accessibility and their prominence in the crime statistics until the 1930s. During the nineteenth and early twentieth centuries charges for drunkenness commonly made up over a quarter of total charges and data on annual convictions for drunkenness was recorded in the official yearbooks until it was decriminalised in $1981 .^{57}$ While this was partly because public drunkenness was common, it was also an offence that was highly visible to the police. It is notable that the prominence of drunkenness in the crime statistics faded rapidly after the passing of the Motor Vehicles Act 1924, which created a new set of highly visible offences. By 1927 infractions of the laws on the lighting and

\footnotetext{
${ }^{3}$ McGill, The Guardians at the Gate, pp. 92-103.

5t Allen Wyllie Margaret Millard and Jia Fang Zhang, Drinking in New Zealand: A National Survey 1995, Auckland, 1996, p. 14 and Ruth Habgood, Sally Casswell, Megan Pledger and Krishna Bhatta, Drinking in New Zealand: National Surveys Comparison 1995 and 2000, luckland, 2001, p. 25.

55 Eldred-Grigg, Pleasures, pp. 209-10.

${ }^{56} \mathrm{Sec}$, for example, Cocker and Murray, p. 117 and Vanguard, licbruary 1949, p. 13.

57 See, for example, NZOYB 1905, pp. 165, 168.
} 
registration of vehicles outnumbered convictions for drunkenness. ${ }^{58} \quad$ This illustrates a major weakness of this indicator - its vulnerability to variations due to police practice. While it is hard to ignore drunkenness statistics because of their frequent use in debates over liquor, in this chapter they will be used sparingly and with appropriate caveats.

\section{Changes in Economic Availability}

The least controversial aspect of the availability theory is its contention that increasing the relative price of alcohol will lower consumption. Liquor is perceived to be an item of discretionary expenditure that consumers will cut back on if its price rises or their income falls relative to price. Alternatively they may substitute for home-manufactured alcoholic beverages. The main way that governments can deliberately affect the price of liquor is through their ability to levy taxes on alcohol. Although New Zealand governments have regularly adjusted tax rates on liquor from time to time, in two cases these adjustments were significant. The largest tax increases were imposed in December 1921 when the duties on beer and spirits were doubled and there were also significant increases in wine duties. ${ }^{59}$ Liquor taxes were also increased a few years earlier in 1915 (spirits only) and in 1917.6

Figure 6.1 below was based on estimates produced in 1930 by prohibitionists Cocker and Murray, who applied standard alcohol content percentages to the three main beverage types to calculate total figures for absolute alcohol consumption which were then converted to per capita rates. The graph shows that overall liquor consumption appears to have dipped slightly following the tax increases of 1915 and 1917. A brief post-war boom in consumption was dramatically interrupted by a significant drop in 1922 following the 1921 tax increases. Consumption then levelled off until 1927, when the series ends. The figures indicate that the 1921 tax rises were followed by a sustained 25 percent drop in consumption of pure alcohol.

\footnotetext{
58 NZOYB 1931, pp. 259, 261.

59 Finance Ict (No. 2) 1921, New Zealand Statutes 1921-22, pp. 255-6 and Customs Imendment Ict 1921, New Zealand Statutes $1921-22$, pp. 167-8.

${ }_{60}$ Finance Act 1915, New Zealand Statutes 1915, pp. 150, 171, Finance Act 1917, New Zealand Statutes 1917.
} 
Figure 6.1: Consumption of Absolute Alcohol per Person 1911-1927, Pints

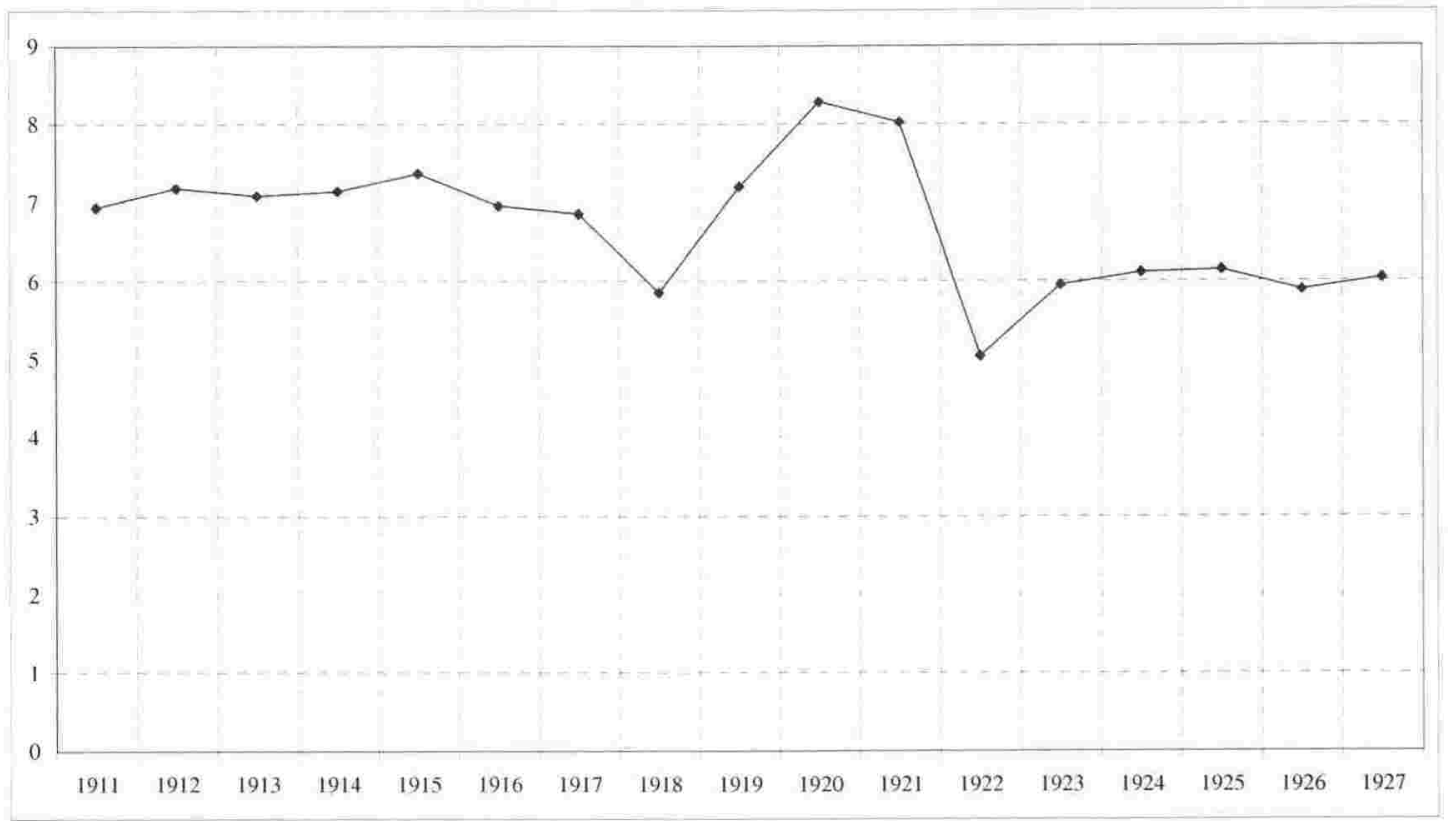

Source: Cocker and Murray, p. 269

Figure 6.2 shows that beer consumption declined slightly in the mid-1920s, which was possibly a consequence of six o'clock closing as consumers switched to more portable liquor in the form of wine and spirits. Figure 6.3 shows that spirits consumption showed greater sensitivity to price changes, falling significantly after the tax increases of 1915 and 1917 and plummeting by over 40 percent between 1921 and $1923 .^{61}$ Both wine and spirits consumption then recovered a little in the mid-1920s, possibly due to substitution from beer to take-home liquor due to early closing. All forms of liquor consumption fell as the recession of the late 1920s became a depression in the early 1930s. Beer consumption fell by 38 percent and wine and spirits consumption halved between 1929 and 1933 . Drinkers appeared even more sensitive to having less money in their pockets than to increases in the price of alcohol. Consumption of all types of liquor started to rise again from the mid 1930s as economic recovery set in.

\footnotetext{
61 The fall was even greater between 1921 and 1922. Part of the reason for especially large decreases in spirits available for consumption immediately after tax rises is that importers will tend to run down existing stocks before importing more liquor at the higher rates.
} 
Figure 6.2: Consumption of Beer per Person 1913-1938, Gallons

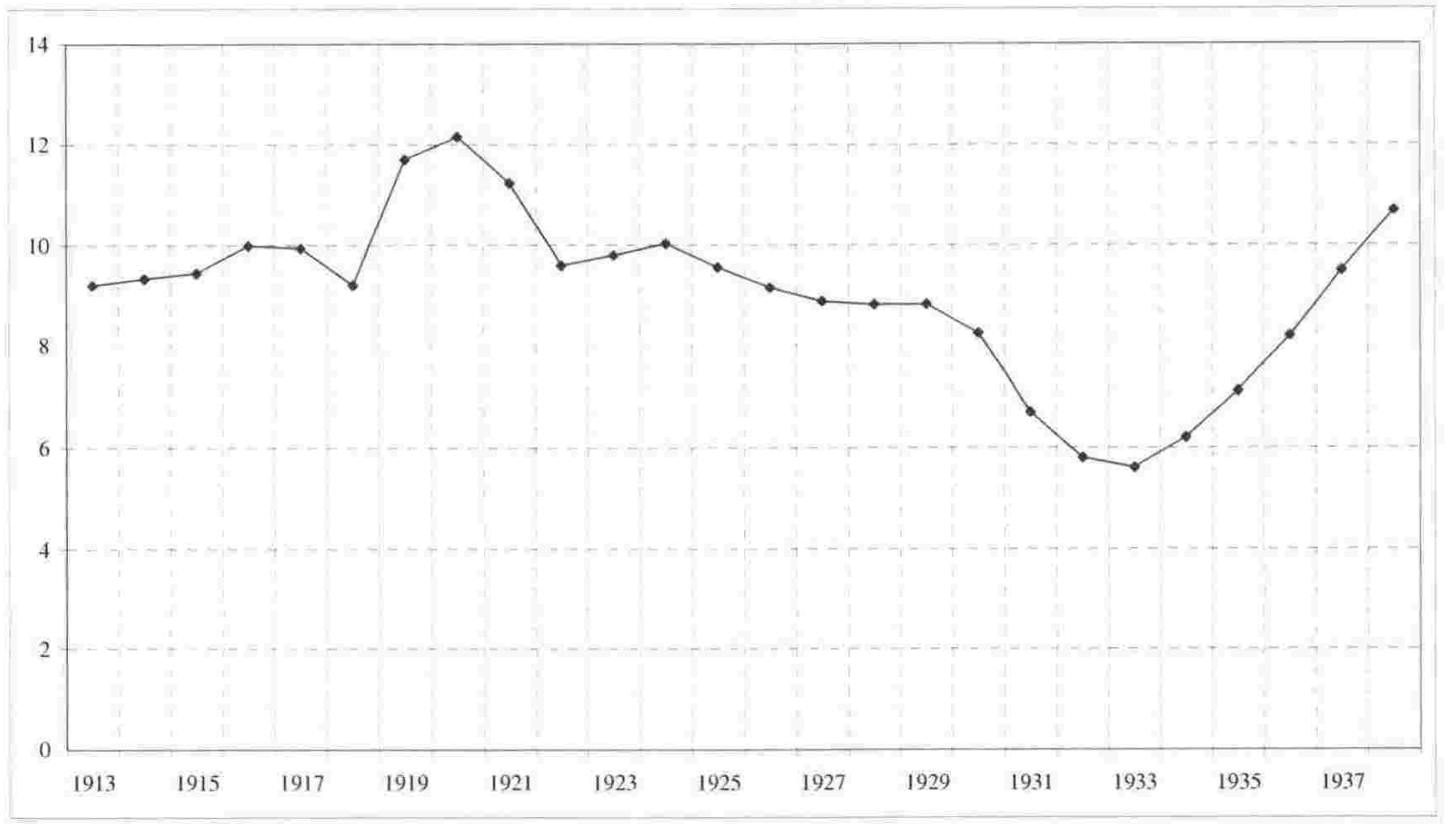

Source: NZOYB 1915-1940

Figure 6.3: Consumption of Wine and Spirits per Person 1913-1938, Gallons

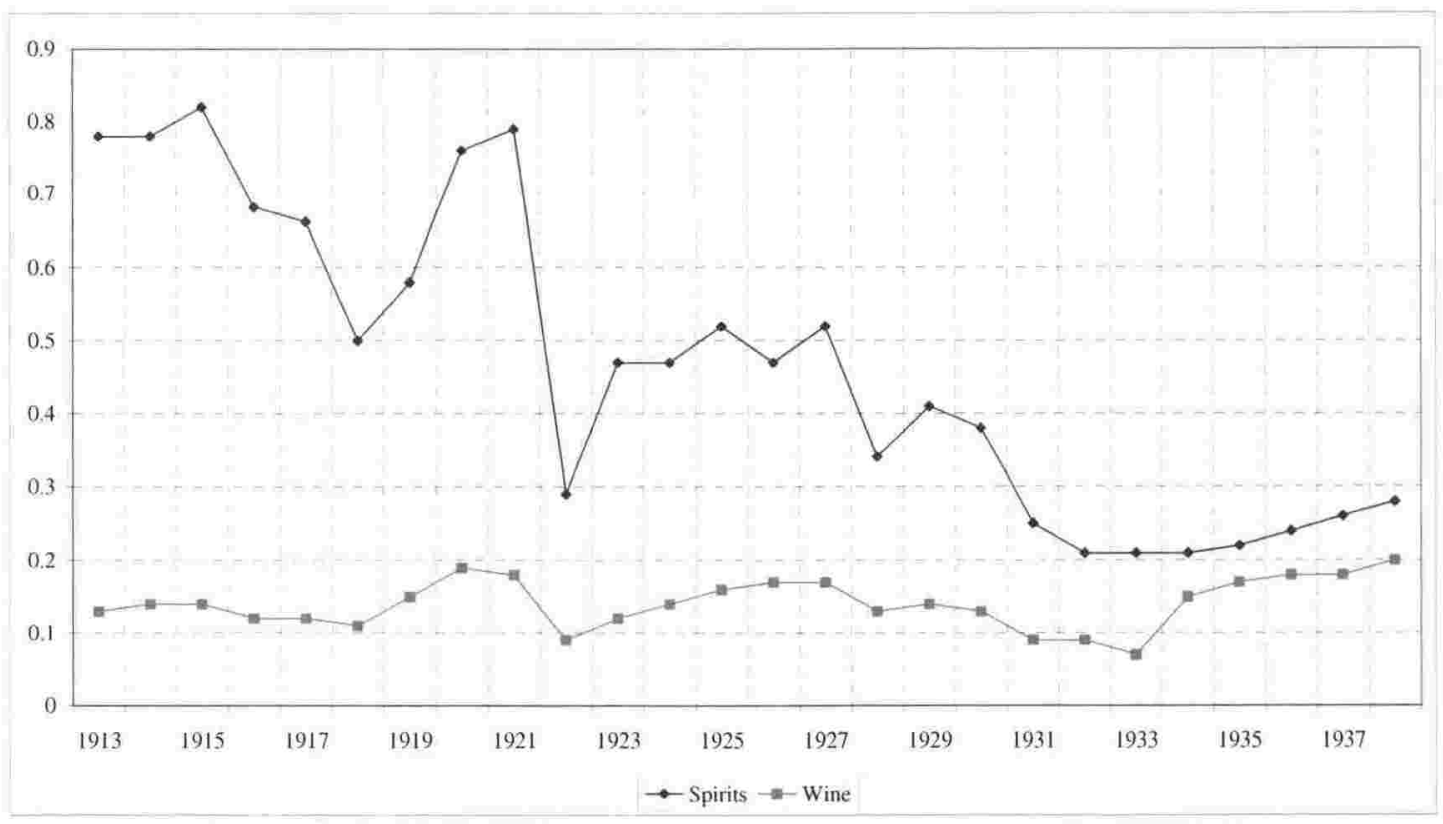

Source: NZOYB 1915-1940 
The next significant rise in liquor taxes came nearly 40 years later when Finance Minister Arnold Nordmeyer doubled the excise taxes on beer and spirits in the 1958 budget. $^{62}$ Figure 6.4 shows that the increases appear to have ended the long climb in per capita beer consumption. Although beer consumption dropped by only four percent between 1957 and 1960 , it took a further six years to recover to its previous level. Figure 6.5 shows that the effect of the tax increase on spirits consumption was significant. Consumption fell by 22 percent between 1957 and 1960 and did not recover to its previous level until the 1970 s. Taxes on wine were not increased in 1958, so not surprisingly wine consumption increased significantly as drinkers substituted from spirits (and to a lesser extent beer) to an alternative that had suddenly become relatively cheaper. As Figure 6.6 shows, the increase in wine consumption did not take off until the 1960 s due to restraints on supply caused by the import licensing system and the time delay needed for local producers to respond to the sudden increase in demand. By the mid-1970s the local wine industry was more than meeting demand. ${ }^{63}$

\section{Figure 6.4: Beer Consumption per Capita 1946-1975, Gallons}

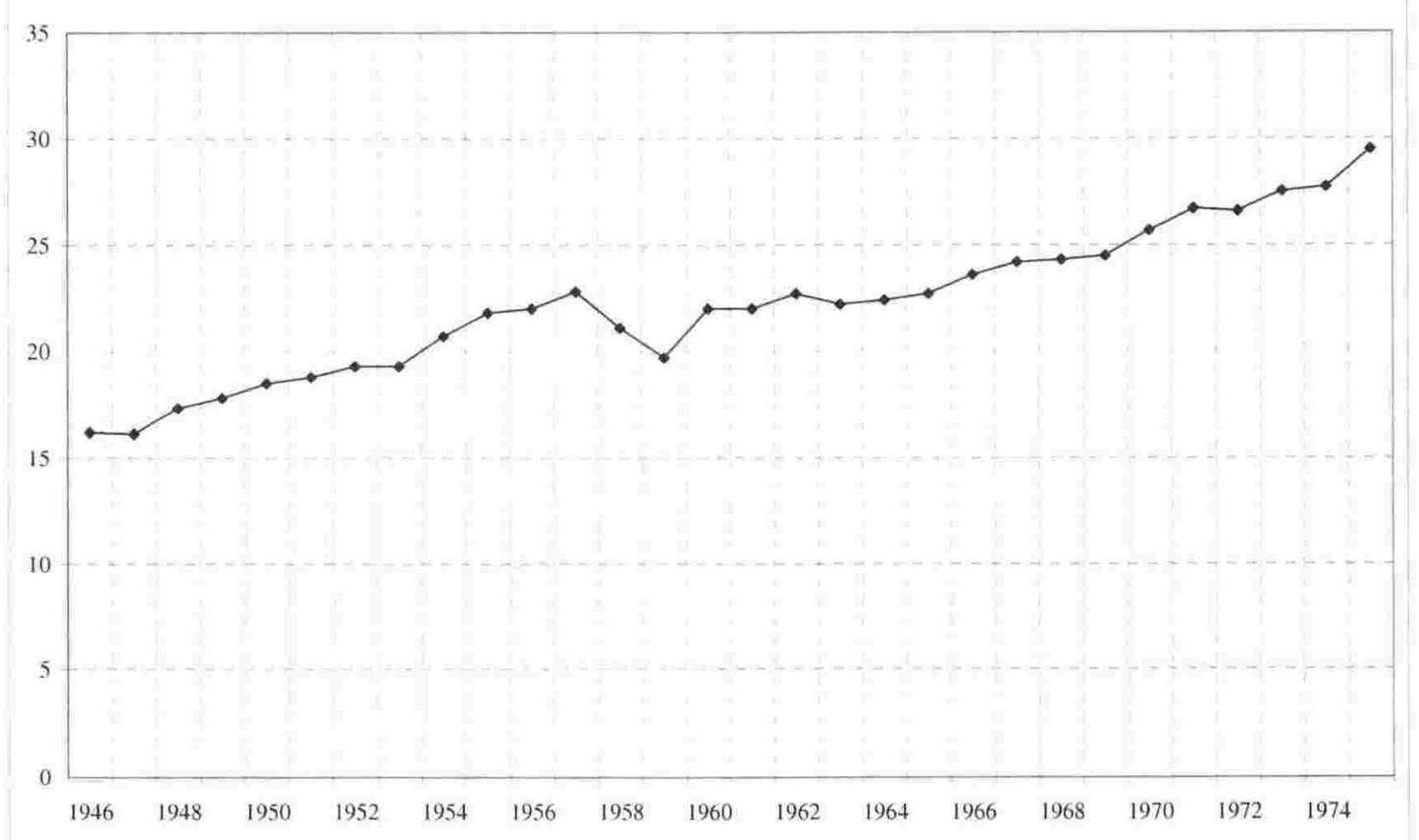

Source: NZOYB 1948-1978

\footnotetext{
62 A.H. Nordmeyer, Budget 1958, 'Financial Statement', AJHR 1958, B.6, p. 32.

${ }^{63}$ Michael Cooper, Wine Atlas of New Zealand, Auckland, 2002, pp. 19-23.
} 
Figure 6.5: Spirits Consumption per Capita 1946-1975, Gallons

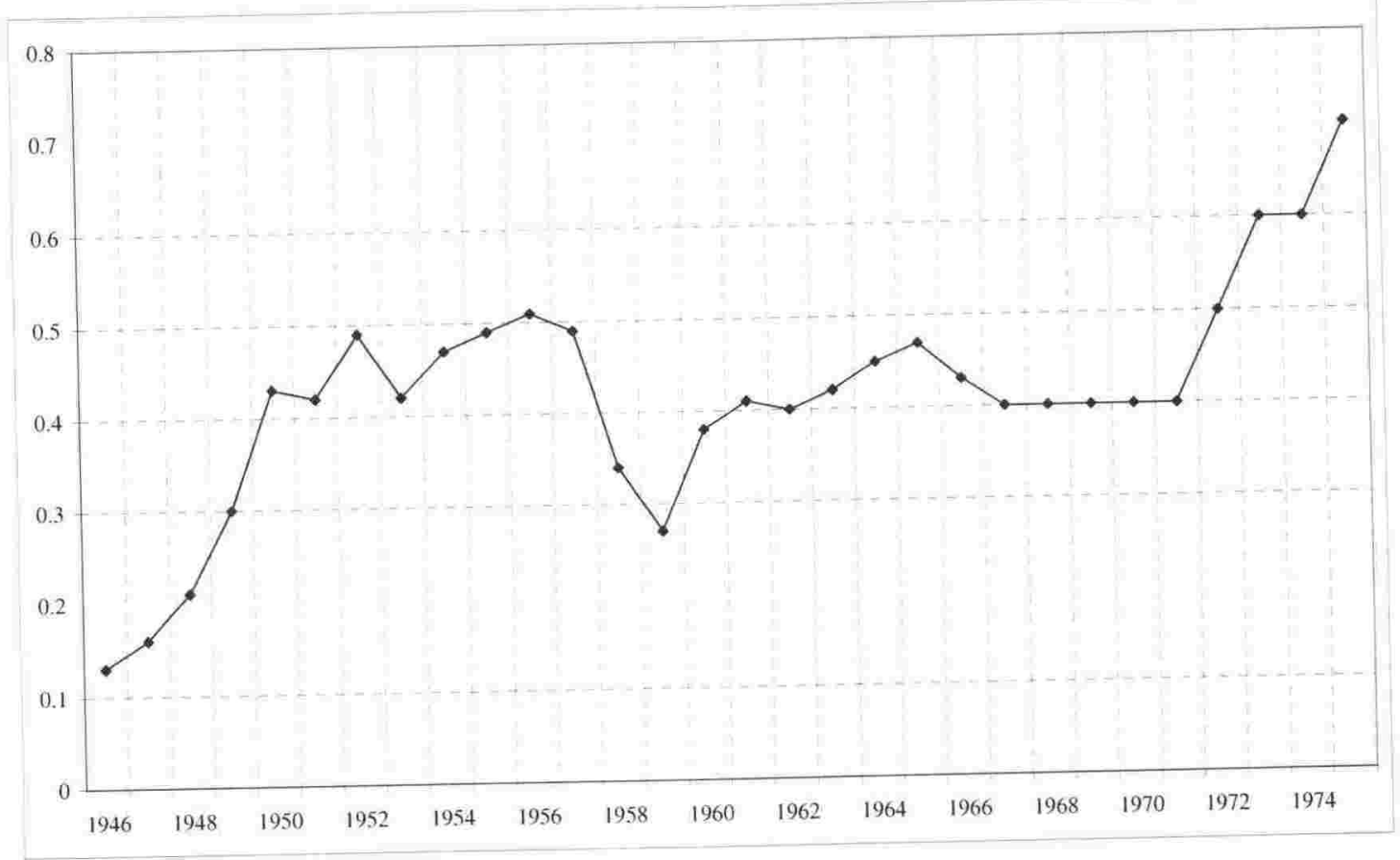

Source: NZOYB 1948-1978

Figure 6.6: Wine Consumption per Capita 1946-1975: Gallons

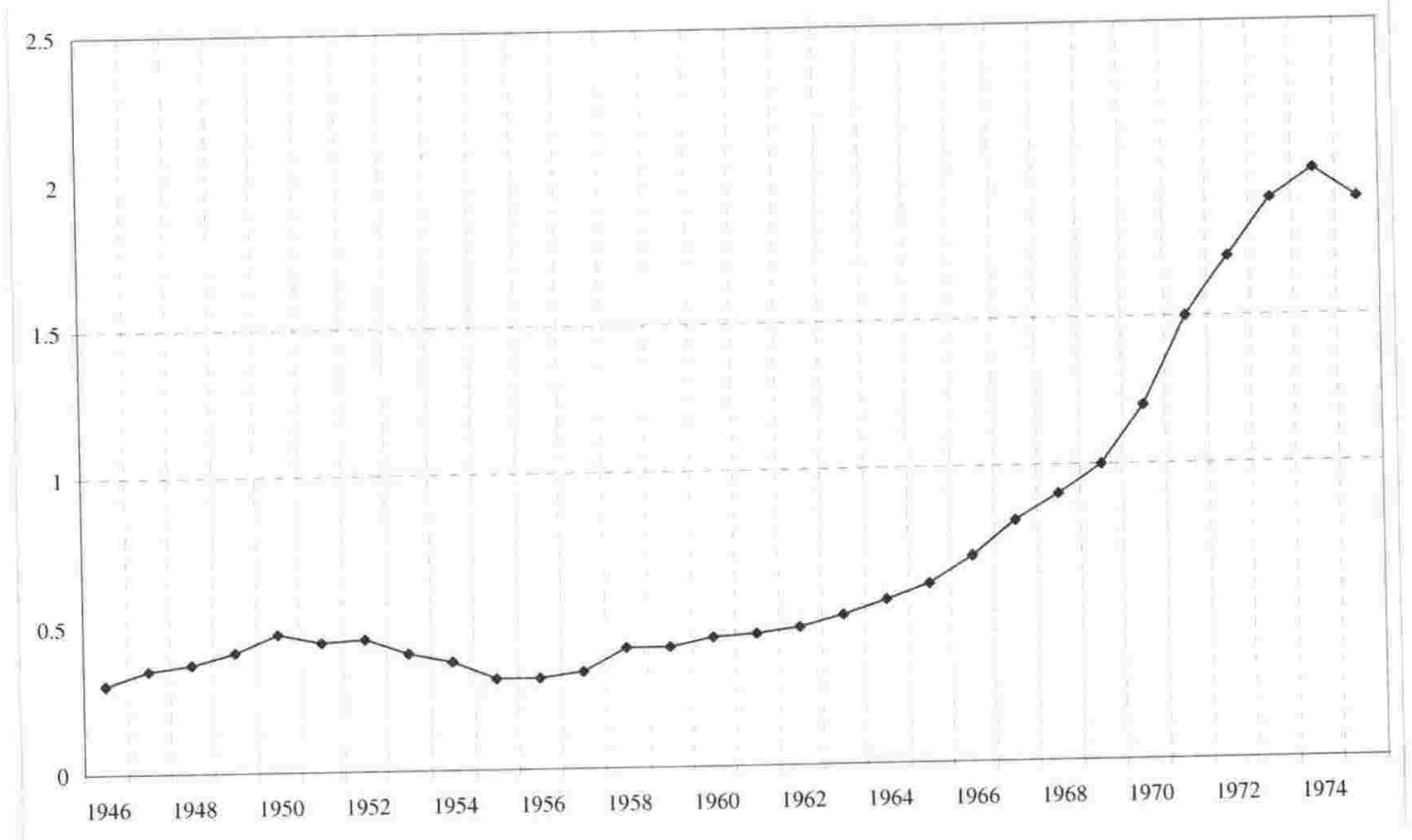

Source: NZOYB 1948-1978

The combined effect of these changes can be seen from figures on per capita consumption of pure alcohol produced for ALAC in 1990, shown in Figure 6.12 below. 
Between 1957 and 1960 there was a seven percent fall in per capita alcohol consumption per person aged over 15. Consumption did not return to its previous level until 1965. Nordmeyer's 'black budget' had demonstrated that increasing the price of liquor could be an effective way of stalling rising consumption. However it also provided an important political lesson, for Labour was decisively defeated in the next general election and spent 20 of the next 23 years in opposition. No government had the courage to raise alcohol excise taxes again until 1976. In the meantime the real price of alcohol fell, and the fall in the real price of spirits in particular was accompanied by a big increase in consumption in the 1970 s. $^{64}$

\section{The Effect of Reduced Outlet Numbers}

While sudden and sharp increases in liquor taxes clearly had an effect on demand, the evidence relating to the physical availability of liquor is less convincing. Chapter 4 outlined how the per capita number of hotels and their associated bottle stores halved in the 16 years from 1894 to 1910 . This was primarily due to population growth and local veto legislation passed in 1893. To some extent the unmet demand due to reduced hotel numbers was taken up by wholesalers, who could supply liquor to the public in quantities of at least two gallons. The number of wholesalers did not change in absolute terms under local veto, although it will have reduced on a per capita basis due to population growth. There was no official ceiling on wholesalers until 1920 when the national number of licences was set at $140 .^{65}$ The small number of chartered clubs licensed to sell alcohol will also have taken up some of the demand caused by hotel closures. The national number of chartered clubs was frozen at 46 in 1908. ${ }^{\text {(6) }}$ Most chartered clubs were reasonably exclusive; over half had fewer than 400 members in 1945 . However the four cosmopolitan and seven working men's clubs had a much larger membership, the largest

ot Ashton and Casswell, Aliobol Pricing Policy in New Zealand, p. 15.

65 Report RCL, pp. 183-4. Wholesalers had to close down in districts that voted no-licence but, unlike hotels, could transfer their operations elsewhere, De la Narc, Drink or Drought, p. 74. The political climate made it unlikely that licensing boards would issue new wholesale licences even before their numbers were officially frozen.

66 Report RCI, pp. 232-4. In addition to the 46 operating chartered clubs, the Ashburton Club's charter was suspended from 1902 to 1932 because it was in a dry district for most of this time. A court battle was required to enable the club to resume the sale of liquor under its charter after the Ashburton electorate was abolished in 1927, Report RCI, p. 207. 
being the Auckland Working Men's Club with 2770 members and the Christchurch Working Men's Club with $1800 .{ }^{67}$

Even with the presence of wholesalers and chartered clubs, the halving in hotel numbers within 16 years is certainly dramatic and was looked upon with satisfaction by prohibitionists. ${ }^{68}$ But did it have the desired effect? Were those, such as MHR James Wallis, correct in claiming a relationship between the number of hotels and the amount of drinking and drunkenness? ${ }^{(9)}$ Reeves wrote in 1902 that the fruits of New Zealand's local option laws 'still remain to be gathered'." He may well have written the same ten years later to judge by the official figures on alcohol consumption and drunkenness. Figure 6.7 shows the trend in per capita beer consumption between 1882 and 1915. As can be seen, consumption had been declining in the 1880s, a trend which levelled off in the 1890s. However consumption increased after 1894 and by 1906 was consistently over nine gallons per head compared with seven in 1895. Per capita beer consumption rose by a third during the period of significant hotel closures.

\section{Figure 6.7: Consumption of Beer per Person 1882-1915, Gallons}

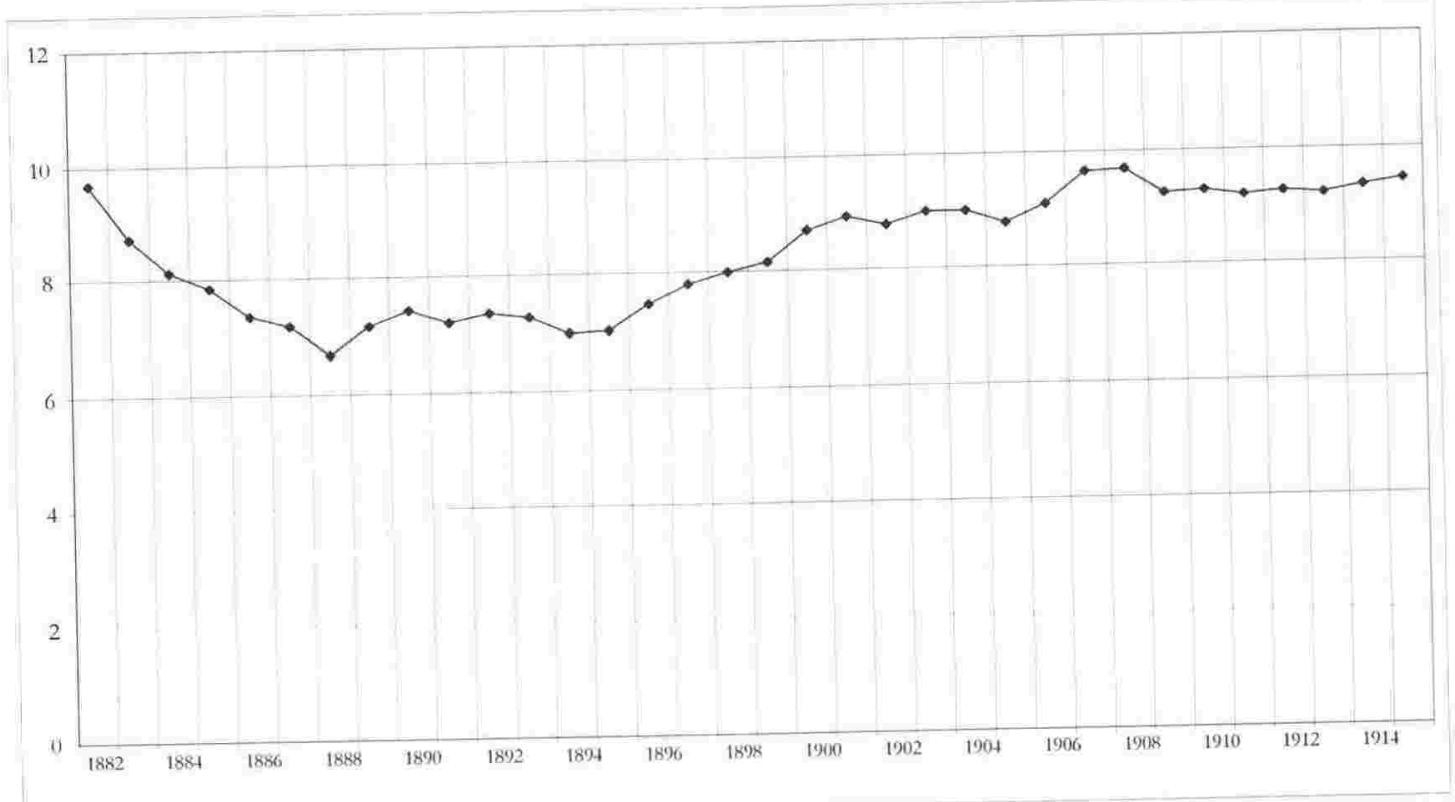

Source: NZOYB 1894-1917

67 A list of chartered clubs and their number of members was supplied to the Royal Commission on Licensing, PRCL, pp. 6202-3. 'Thirteen clubs had a thousand or more members.

is Cocker and Murray, p. 272.

69) N/PD 1881, volume 38, p. 129.

70 Reeves, State Experiments, volume 2, p. 309. 
The local veto period was not accompanied by any change in the consumption of wine, very little of which was drunk in the colony. However it did coincide with a rise in spirits consumption, as shown by Figure 6.8. Spirits consumption declined dramatically in the 1880 s, with a sudden drop in 1889 coinciding with a tariff rise. ${ }^{71}$ But from its low of 0.6 gallons per head in 1895, consumption started to increase again. After 1901 spirits consumption was generally over 0.7 gallons per person and peaked at 0.8 gallons before a tariff rise at the end of 1915 . The increase in consumption during the period of local veto between 1894 and 1910 was over 20 percent. Not surprisingly, the increase in liquor consumption was accompanied by an increase in drunkenness convictions, as shown by Figure 6.9. The annual rate gradually decreased from nine to 6.6 per 1000 between 1888 and 1894, but then started to climb dramatically. After 1901 annual drunkenness convictions consistently ranged between ten and 12 per 1000 , an increase of some 60 percent from the mid 1890 s.

Figure 6.8: Consumption of Wine and Spirits per Person 1882-1915, Gallons

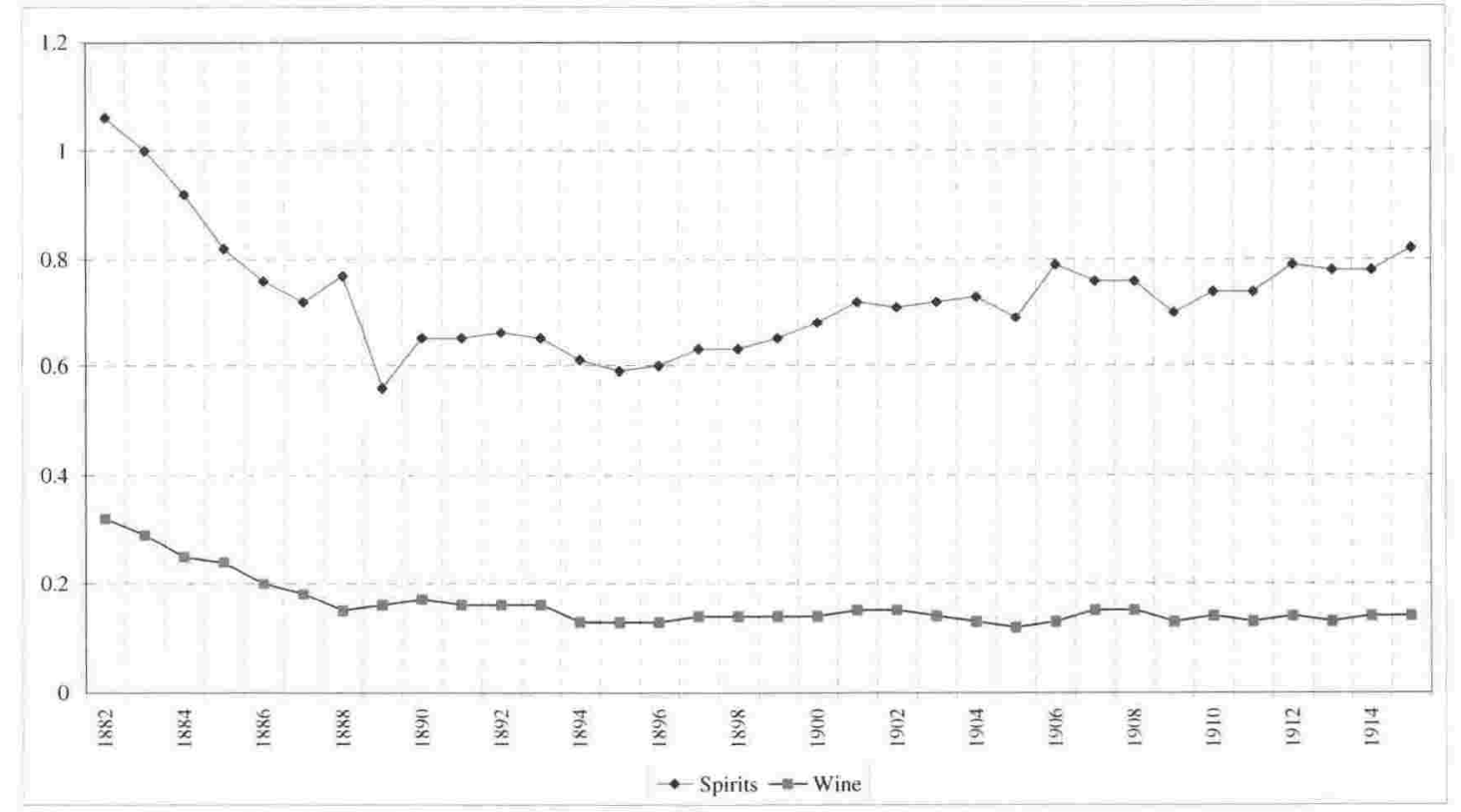

Source: NZOYB, 1894-1917

It should be noted that although the rate of liquor consumption and drunkenness convictions rose during the period under discussion it was still a fraction of what it had been in the 1850 s and 1860 s, as Miles Fairburn has shown. ${ }^{72}$ This qualification aside, the evidence on local veto available from official sources provides little support for the

\footnotetext{
71 Customs and Dutics Excisc Act, Nen Zealand Statutes 1888, p. 17.

72 Fairburn, The Ideal Society and its Enemies, pp. 206-8.
} 
availability theory. It could even be claimed that the reduction in hotel numbers actually led to an increase in drinking and drunkenness, although such a claim would be difficult to sustain. Reeves no doubt correctly attributed the increases after 1895 to a return to prosperity after a prolonged economic downturn. ${ }^{73}$ Renewed prosperity was accompanied by a revival in immigration, particularly after $1900 .^{74}$ As official yearbooks regularly noted, immigrants tended to be over-represented in the drunkenness statistics. ${ }^{75}$ Another demographic change that would have contributed to the increase in rates of alcohol consumption and drunkenness convictions was the falling birth rate. This resulted in a rising median population age due to fewer children - in other words a greater proportion of the population were adults likely to have consumed alcohol. ${ }^{76}$ Thus demographic change will have slightly inflated crude per capita rates of alcohol consumption and drunkenness convictions calculated on the basis of the total population.

\section{Figure 6.9: Drunkenness Convictions per 1000 People (excluding Maori) 1888-1915}

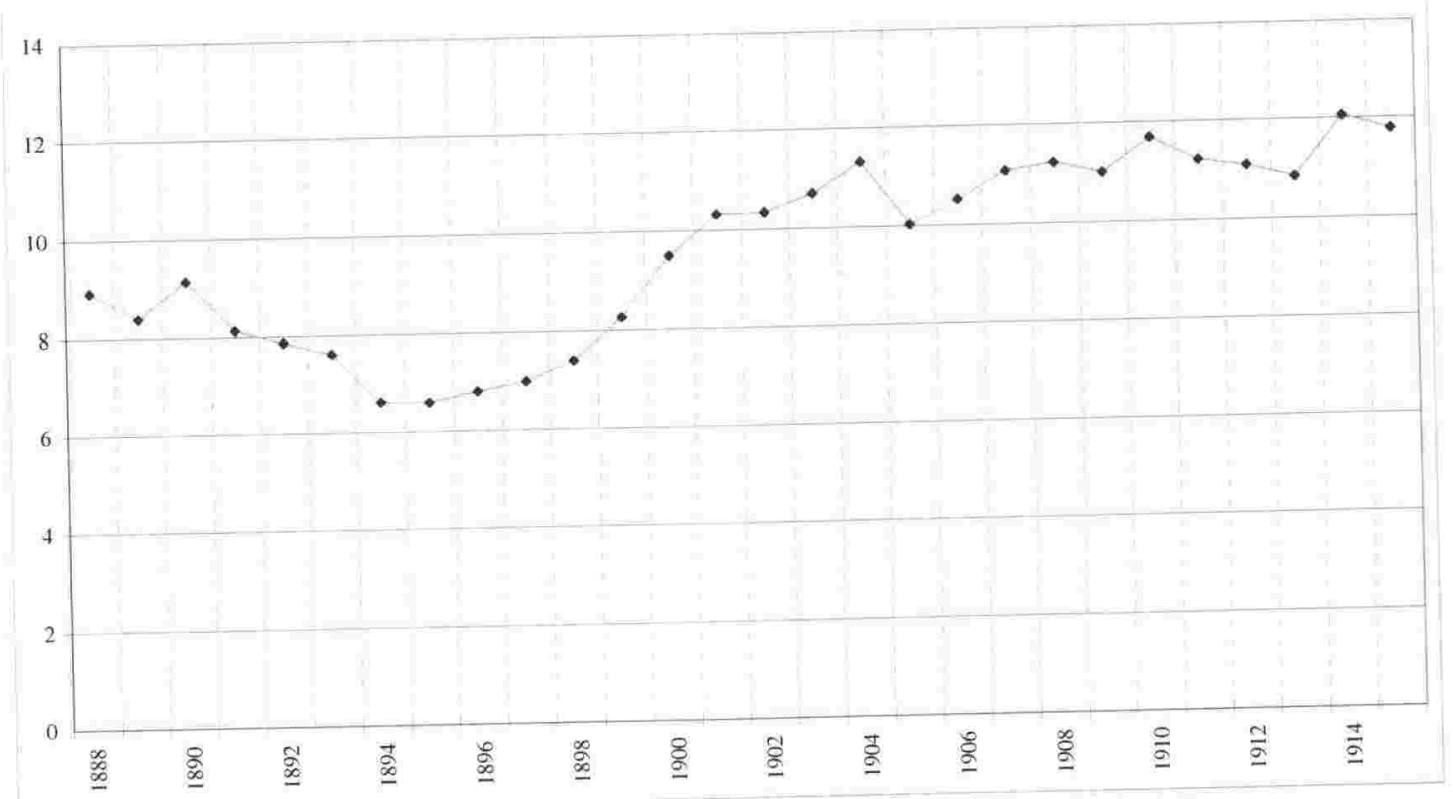

Source: NZOYB, 1894-1917

More vigilant policing of the laws under prohibitionist pressure may have contributed to the rise in drunkenness convictions. The 1898 Royal Commission on the Police Force commented on the insistence of witnesses that the licensing and related laws be strictly

\footnotetext{
73 Reeves, State Experiments, volume 2, pp. 318-19.

$7+$ NZOYB 1990, p. 153.

75 Scc, for cxample, N/OYB 1898, p. 189 and N/OYB 1902, p. 282.

76 NZOYB 1990, pp. 139-141.
} 
enforced. ${ }^{77}$ The courts appear to have responded by letting even fewer of those arrested for drunkenness escape conviction, although prohibition activists often claimed that the laws were laxly enforced. One Saturday night in 1903 they staked out 37 Auckland hotels and claimed that 560 people were seen to emerge from them 'decidedly under the influence of liquor', although only ten people were arrested for drunkenness that weekend. ${ }^{78}$ This example illustrates both how keen the prohibitionists were to pressurise the authorities to enforce the law and also how subjective the concept of 'drunkenness' can be.

\section{The Effect of Six o'clock Closing}

As outlined in Chapter 5, from 1 December 1917 New Zealand hotels were prohibited from serving alcohol in most circumstances after six $\mathrm{pm}$ and before nine am. ${ }^{79}$ This equated to a 44 percent reduction in legal opening hours, a reduction split between a period of high demand, from six pm to ten pm, and a period of low demand, from six am to nine am. It was argued by supporters and by many opponents of the restrictions that the change would result in less alcohol being consumed.

Figure 6.4 above shows that the introduction of six o'clock closing was followed by a period of lower alcohol consumption from the early 1920s. However this begs the question as to why consumption did not decrease until some five years after the reform. A reason can be found in the previous section, when it was argued that the fall in consumption can be attributed to the increases in liquor taxes implemented in 1915, 1917 and especially 1921. The return of troops and a brief post-war economic boom led to a brief surge in demand for alcohol, but the 1921 tax increases coincided with the end of the post-war boom, and liquor consumption fell as a result.

Figures 6.5 to 6.7 above show that the main effect of early closing appears to have been some substitution from beer to wine and spirits in the mid-1920s due to a greater reliance on takeaway liquor. Alcohol consumption fell further during the depression and did not pick up again until the mid-1930s. There are no official statistics available for liquor consumption between 1939 and 1946, but consumption rose dramatically after the war.

\footnotetext{
77 'Report and Evidence of the Royal Commission on the P'olice Force of Ncw 'Kealand', AJHR 1898, H-2, p. xxv.

78 Grigg, 'Prohibition and Women', p. 138.

${ }^{79}$ Sale of Liquor Restriction Act, Nen Zealand Statutes 1917, p. 90.
} 
Between 1947 and 1957 spirits consumption per head leapt by over 200 percent and beer consumption by 42 percent, despite no change in hours of sale. ${ }^{80}$ The rate of increase was interrupted for several years by a big increase in alcohol excise duties in 1958, but continued its climb in the 1960 s, at least in the case of beer and wine.

It was noted earlier that the Alliance commonly claimed that six o'clock closing had lead to a decline in drunkenness. Some witnesses to the 1945 Royal Commission on Licensing were under the impression that public drunkenness had declined since 1917. For example a Napier Magistrate said there was a lot more drunkenness and crime in the old days. ${ }^{81}$ However some who agreed with such views attributed the change to the fact that there was more for young people to do in the evening with the spread of evening entertainments such as the cinema. ${ }^{82}$ Others claimed that things had got worse rather than better with early closing. A Wellington clerk in his sixties testified that pubs were more pleasant places in former times and there was 'less drunkenness in the streets. ${ }^{33} \mathrm{~A}$ senior police officer said that pubs were 'a little worse' in the old days, but 'today it is takeaway liquor and problems elsewhere. ${ }^{84}$ The anecdotal evidence on the issue was therefore somewhat mixed.

The statistical evidence throws some light on the issue. Figure 6.10 shows the long term trend in drunkenness conviction rates over 70 years. It is notable that the rate fell almost continuously throughout the period, a trend that became increasingly independent from overall rates of alcohol consumption over time. It would be easy to mistakenly attribute the onset of the decline in drunkenness to the introduction of six o'clock closing as one writer did in $1999 .{ }^{85}$ In fact the 34 percent fall in drunkenness convictions during 1916 and 1917 occurred almost entirely before the introduction of early closing in December 1917. Indeed, MPs had discussed the apparent major decline in drunkenness when debating the Bill to reduce legal opening hours. ${ }^{86}$ Despite early closing, drunkenness

\footnotetext{
${ }^{80}$ Bloomficld, Handbook of Historical Statistics, p. 121.

81 PRCL, p. 152.

82 PRC.L, PP. 898 and 2964.

83 PRCl., p. 1737.

8+ PRCL, p. 898.

85 Graeme Dunstall, A Policeman's Paradise? Policing a Stable Society 1918-1945, Palmerston North, 1999, p. 147.

${ }^{86}$ NZPD 1917, volume 180, pp. 220-1, 258-9.
} 
convictions rose as soon as the war ended, in line with the temporary boost in alcohol consumption.

Figure 6.10: Drunkenness Convictions per 1000 People, 1912-1974

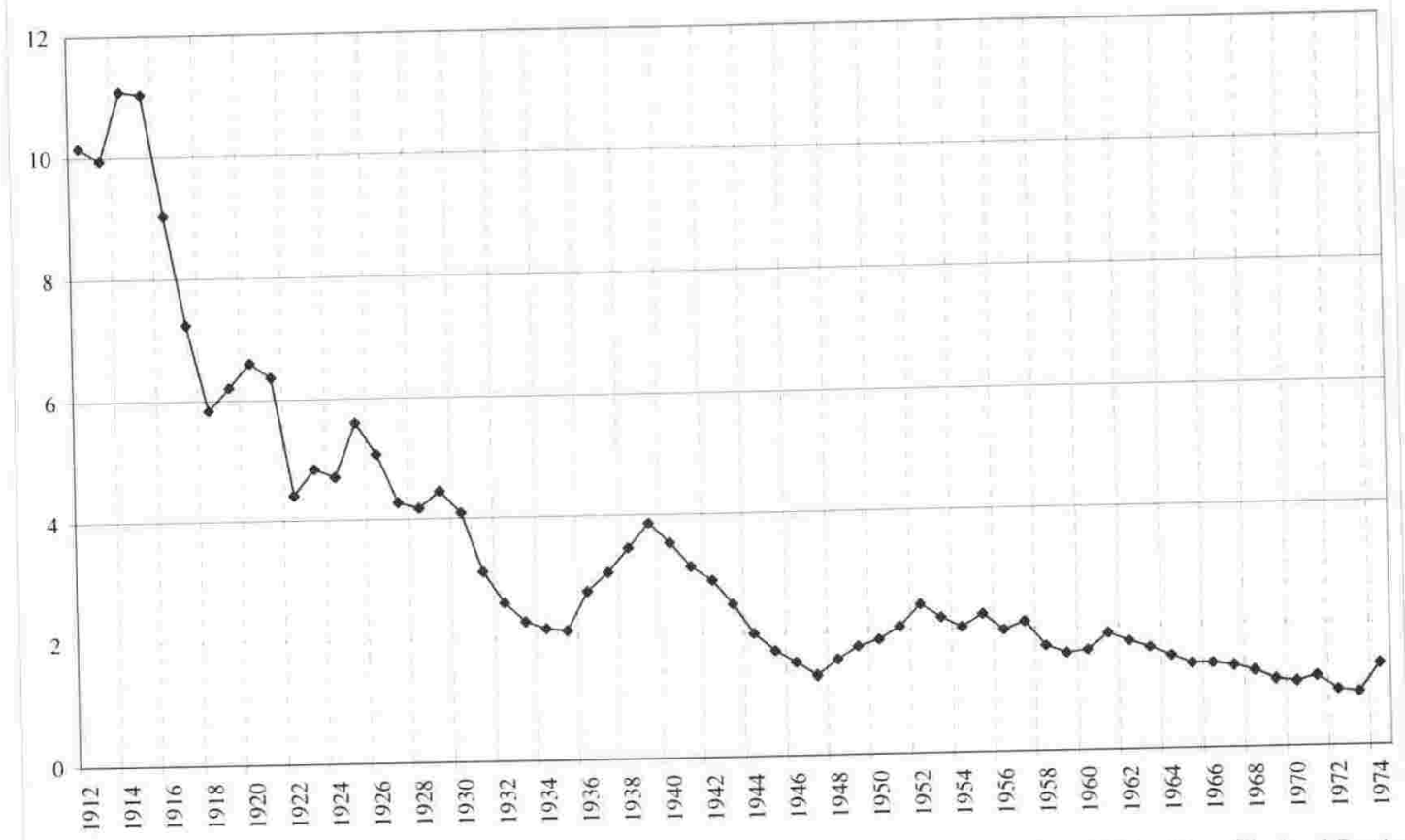

Source: Calculated from Department of Statistics, Statistics of New Zealand, 1912-1919, New Zealand Justice Statistics, 1920-1974, NZOYB 1990, p. 128. Figures have been interpolated for the years 1942 to 1946 due to lack of official data.

Several factors may have contributed to the dramatic decline in drunkenness convictions during World War One. The pre-war starting point was probably artificially high due to relatively strict enforcement of the laws (as discussed earlier). Arrests, particularly for minor offences, tend to fall during wartime due to labour shortages, which affect the police as much as other sectors. The proportion of young males in the population fell dramatically as troops left for the war, many never to return, and the proportion of foreign-born also dropped as immigration slowed. The rate of spirits consumption fell dramatically, with evidence from earlier periods showing a correlation between spirits consumption and drunkenness arrests. ${ }^{87}$ One explanation that can be discounted is that the introduction of 'anti-shouting' regulations in 1916 was a cause of the big decline in drunkenness as claimed by Prime Minister William Massey the following year. ${ }^{88}$ The

\footnotetext{
${ }_{87}$ Lairburn, The Ideal Society and its Enemies, p. 209.

${ }^{8 B}$ NZPD 1917, volume 180, p. 217.
} 
decline was at least as large in no-licence districts where the prohibition on buying drinks for others was irrelevant due to the absence of bars. ${ }^{89}$

But why did the rate of drunkenness convictions continue to fall throughout the century? In part the trend may have been linked to a continued decline in the consumption of spirits, but over time this correlation all but disappeared despite the large increase in spirits consumption after the Second World War. A plausible explanation for the observed pattern is the rise of the motor vehicle. Firstly, offences such as non-registration of motor vehicles absorbed increasing police attention at the expense of other minor offences. Secondly, those leaving the pub increasingly took their own motorcar home rather than walking or using public transport. Once in their vehicles drinkers were relatively safe from the enforcement authorities. The chance of detection and conviction for drink driving was minimal until the 1970s. A uniform set of road rules for the country was not established until 1928 and an objective measure of intoxication in the form of voluntary blood testing was not introduced until 1966." This was followed by an immediate increase in drink driving convictions, which surpassed 1000 per annum for the first time in $1967 .^{92}$ In 1969 two-stage testing was introduced - a breathalyser screening and a compulsory blood test - followed in the 1970 s by random screening, evidential breath tests and drink-driving blitzes. ${ }^{13}$ Annual drink driving convictions increased exponentially as a result, surpassing 4000 in 1970 and 9500 in $1975 .{ }^{.4}$

Increasing motor vehicle use may have contributed to a fall in drunkenness convictions in the $1920 \mathrm{~s}$, but it also led to a rise in vehicle accidents involving alcohol. By 1930 motor vehicle ownership reached 220,000 , a 56 percent increase in four years. ${ }^{95}$ The rate of road accidents rose dramatically and annual road deaths exceeded 200 by $1930 .^{96}$ Driver intoxication was considered to be a factor in 12 percent of 393 fatal motor vehicle accidents in the two years to 31 March 1932. The accidents most commonly took place

\footnotetext{
89 See Figure 7 in the next Chapter.

90 NZOYB 1931, pp. 259, 261.

${ }^{21}$ N7OYB 1990, p. 554.

${ }^{22}$ NZOYB 1973 , p. 250.

93 A detailed account of these changes is provided by I. MacDonald, H. M. Stone and G. L. Dick, "The Problem of the Intoxicated Driver', in H.M. Stone, ed., Akobol, Drygs and the New Zealand Driver, Wellington, 1982, pp. 1-11.

94 N $2 O Y B, 1973$ and 1978.

${ }^{55}$ N/OYB 1927 , p. 402 and 1931 p. 383. For long term time scries on vehicle ownership see NZOYB 1990, pp. 548-9.

$\%$ NZOYB 1932, p. 138.
} 
on Saturday, and most frequently between four and seven $\mathrm{pm}$, coinciding with the most popular drinking times. ${ }^{97}$ There is therefore circumstantial evidence that by 1930 many of those who formerly may have been convicted of being drunk in a public place were relatively safe from prosecution (if not injury or death) in their motor vehicles. The fall in drunkenness convictions in the 1920s can at least in part be explained by the rise of the motor vehicle. The continued fall in the 1950 s and 1960 s almost certainly can. By the 1960 s, drunkenness per se was no longer an issue of common public discussion, but drinking and driving certainly was. Even the Alliance noted in 1964 that the real problems arising from alcohol consumption were alcoholism and drink driving rather than drunkenness. ${ }^{98}$

When early closing finally ended on 9 October 1967, new opening hours of 11 am to ten pm were introduced. There had been a minor liberalisation seven years earlier that allowed the new licensed restaurants to serve liquor as late as $11.30 \mathrm{pm}$. This change in itself was of little consequence, for there were still only 44 licensed restaurants nationally by $1966 .{ }^{99}$ Of more significance was the fact that the same hours were extended to the dining facilities of licensed hotels, which had previously been allowed to serve liquor only until eight pm. ${ }^{101}$ It is unclear how much business hotel restaurants actually did, for as discussed in Chapter 4, publicans generally had little interest in providing food and accommodation. However the situation may have been different for larger hotels, for one researcher found that three major Dunedin hotels were popular for 'fine dining., ${ }^{101}$ Before 1967, at least some New Zealanders would have gained experience with legal late-evening drinking without travelling abroad or staying in a licensed hotel.

The reform in restaurant hours aside, the increase in legal hours of sale introduced in 1967 for hotels, taverns, chartered clubs and bottle stores was a significant change. Although the total increase in opening hours was only 22 percent, four extra hours were allowed in a period of potentially high demand between six and ten $\mathrm{pm}$, while the loss of two hours between nine and 11 am was inconsequential. So what effect did this have on drinking and drunkenness? As can be seen from Figure 6.10 above, the percentage of people

\footnotetext{
97. AJHR 1937-8, H-40, p. 14, table 14.

98 Vangrard, Special number, 1964, p. 4.

") Licensing Control Commission Annual Report 1966, AJHR 1966 II3, p. 15.

${ }^{100}$ Stace, p. 213.

101 Fidwin West, 'Trom Pea, Pie and Pud to Nouvelle Cuisine: 'The History of Tating Out in Dunedin, 1935 to 1980', B 1 Ionours I listory Research Essay, University of (Otago, 2000, pp. 17, 28, 47.
} 
convicted for drunkenness each year continued to decline after 1967 despite the return of ten o'clock closing. The 1945 Royal Commission on Licensing noted a similar phenomenon when early closing ended in Tasmania in 1937; there was no discernible effect on drunkenness convictions. ${ }^{102}$ Figure 6.4 above shows that, while estimated beer consumption per capita rose after 1967, it had already been rising continuously since 1959 . It would be expected that beer consumption would rise with greater time available for onsite consumption, but consumption remained relatively flat in 1968 and 1969 before resuming its previous rate of increase in the 1970s. Figure 6.5 shows that the end of early closing had no effect on spirits consumption, which had remained subdued after the big tax increases of 1958 before taking off again from 1972. Wine consumption (Figure 6.6) continued its upward trajectory after its exemption from the 1958 tax increases, more than doubling in the 1960s and doubling again in the early 1970s. It would be difficult to make a case that the increase was in any way related to the end of six o'clock closing.

As was outlined earlier, drink-driving offences are an unreliable measure of alcohol-related harm because of changes in enforcement practice. However it is possible to measure the effect of the change in drinking hours on traffic accidents. A 1974 report produced for the Ministry of Transport found little change in the number of traffic accidents before and after the introduction of ten o'clock closing. ${ }^{103}$ The researchers attributed a slight fall in accident numbers immediately after the change to economic recession, although they did speculate that the moving of pub closing away from the after work rush-hour may have been a contributing factor. The main concentration of traffic accidents shifted to the hour after $10 \mathrm{pm}$, rather than the hour after six $\mathrm{pm}$ as it had been before the change. ${ }^{104} \mathrm{~A}$ 1982 study used a slightly different methodology, analysing changes in the timing of injury-related road accidents between 1962 and 1979. ${ }^{105}$ Accidents were classified as daytime (six am to six pm) or night-time, on the assumption that accidents at night are substantially more likely to involve alcohol than those during the day. It was found that accidents at night became more common in the three years after the start of ten o'clock closing, indicating that the change in drinking hours may have led to more drinking and driving, with people more commonly going to hotels in the evening rather than directly from work. However the ratio between day and night accidents returned to previous

\footnotetext{
102 Report RCl, p. 93.

${ }_{103} \mathrm{~J}$. B. Toomath and Thuc Nguyen, The Effect on Traffic Accidents of Extended Trading Hours at Hotels, Wellington, 1974.

$10+$ Toomath and Nguyen, pp. 2-6.

105 I. MacDonald et al, 'The Problem of the Intoxicated Driver'.
} 
levels during most of the 1970 s, aided by the significantly increased enforcement of the drink-driving laws discussed earlier.

One piece of evidence relating to the ending of six o'clock closing provides some support for the availability theory. Figure 6.11 shows that, although there was no overall increase in the annual rate of convictions for drunkenness when six o'clock closing ended in 1967, the rate for Maori did increase. ${ }^{106}$ It may be that Maori developed a habit of drinking in public bars earlier in the century because of the restrictions on the purchase of takeaway liquor, and the evening closing of bars may therefore have inhibited problem drinking for some. An alternative explanation is that by the late 1960 s Maori were increasingly moving from smaller to larger urban areas where they were perhaps more likely to come to the attention of enforcement authorities. More in-depth research would be needed to disentangle the various causal factors.

Figure 6.11: Maori and Non-Maori Convictions for Drunkenness per 1000 Population, 1947-1976

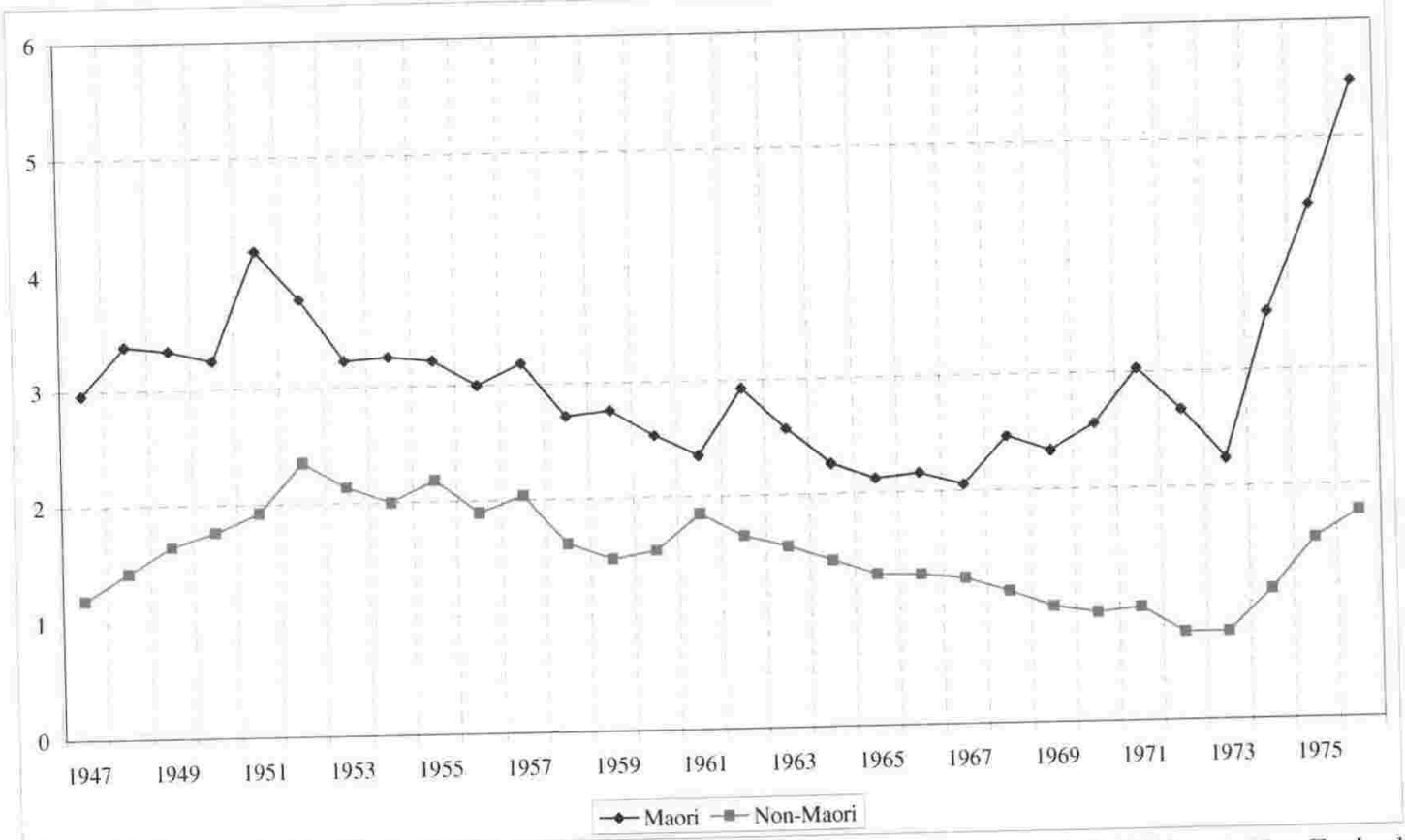

Source: Calculated from Department of Statistics, New Zealand Justice Statistics 1947-1976 and New Zealand Population Statistics, 1947-1976. The figures relate to arrest cases only.

This exception aside, the end of six o'clock closing does not appear to have led to any general increase in drinking or drunkenness. Circumstantial evidence indicates it may

106 'The data used in Figure 6.11 was originally collected for my honours research essay, Paul Christoffel, 'Crime and the Maori: An I Iistorical Perspective', BA I Ionours Research Essay, Victoria University of Wellington, 1988. 
have led to an increase in traffic accidents involving alcohol. However this apparent increase was only temporary due to better enforcement of the laws against drinking and driving after 1970. It appeared that alcohol-related harm could be reduced by targeting those at risk of damaging themselves and others rather than by attempting to curtail the drinking of the entire population.

\section{Liberalisation from the late 1970 s}

Between 1977 and 1987 the number of licensed liquor outlets per capita increased by 150 percent. As was seen in Chapter 4, the increase was driven by the licensing of sports clubs, making restaurant licences easier to obtain, and the introduction of BYO permits. Hours of sale were also liberalised in the late 1970s. From December 1976 hotels and taverns could obtain permits to close at $11 \mathrm{pm}$ on Friday night, Saturday night and Christmas Eve, and at 12.30am on New Year's Eve. ${ }^{107}$ After 1977 cabarets could open until three am six days a week. ${ }^{108}$ Some club ancillary licenses allowed them to legally serve alcohol without food on Sundays. ${ }^{1(1)}$ The 1986 Working Party claimed that the proliferation of sports licences in particular had resulted in a large increase in the availability of liquor after $1977 .^{110}$ ALAC disagreed, claiming in 1988 'it is debatable whether there has been any real increase in availability.' ${ }^{111}$ ALAC's main argument was that sports clubs had been commonly selling alcohol illegally before the change, a contention backed up by evidence from other bodies. The Liquor Industry Council submitted to the 1974 royal commission that illegal liquor sales by clubs had been increasing since the early 1960 s, and by the 1970 s they provided a rival outlet to pubs. ${ }^{112}$ A parliamentary select committee set up in 1978 to look into the operation of the ancillary licence stated that ' $[\mathrm{m}]$ any clubs had long operated unlawful liquor facilities for the benefit of their members, though this had largely been ignored by the authorities.' ${ }^{113}$ The Licensing Control Commission reported in 1984: 'It is incorrect to say, as is sometimes

\footnotetext{
107 Stace, pp. 206, 208.

108 Sale of Liquor Amendment Act, New Zealand Statutes 1977, p. 1769.

109) Stace, p. 348 ,

110 Working Party on I iquor, pp. 34-5.

111 ALAC, 'The Availability Issue', cmphasis in original.

${ }^{112} \mathrm{New}$ Zealand liquor Industry Council submission, Section 3, p. 2.

113 New Zealand Liquor Industry Council, Section 3, p. 5.
} 
suggested, that when we authorise a new club licence, we are creating a new drink outlet. We are, in the majority of cases, simply licensing an existing outlet. ${ }^{114}$

On the other hand the 1978 parliamentary select committee reported that the new general ancillary licence had already affected the patronage of hotels and taverns, especially in suburban areas. ${ }^{115}$ This provides evidence that not all club licences were simply licensing existing outlets. All the same, clubs had clearly flouted the law for some time, and the seemingly sudden increase in liquor availability through sports clubs after 1977 was therefore probably largely the formal recognition of an existing situation. Whatever the situation regarding clubs, the near quadrupling in the number of licensed restaurants in ten years was a genuine increase in liquor availability. It could also reasonably be argued that the introduction of BYO permits increased availability by introducing a new range of opportunities for public drinking. BYO restaurants helped boost the popularity of restaurant dining, for patrons could enjoy a bottle of wine while eating out without paying the inflated prices charge by licensed restaurants. With BYO permits, extended hours and more outlets, it is hard to sustain a case that there was no increase in liquor availability after 1977. At best it can be argued that the true extent of the increase is hard to quantify because some previous restrictions were often ignored or were poorly enforced. ALAC was perhaps being a little disingenuous in claiming otherwise in 1988. Five years earlier, when it appeared that the long rise in liquor consumption had only temporarily stalled, ALAC had been happy to argue that the increase in drinking was because 'alcohol has become available through more outlets and over longer hours'. ${ }^{116}$ Once it became clear that consumption was actually falling the organization changed its tune and claimed the increase in availability was probably illusory.

The plateauing of alcohol consumption in the mid 1970s and its fall from the early 1980s can be seen from Figure 6.12. The data comes mainly from estimates produced in 1990 by H.K. Orchard, who used a variety of sources to calculate the probable average alcohol content of different types of beverage. ${ }^{117}$ The figures became more precise from 1984 due to different rates of excise being imposed on beer depending on alcohol content. Statistics New Zealand continued the series from 1990 and reports them regularly in its

\footnotetext{
11+ J.CC Annual Report 1984, NJHR, T:8. 1984, p. 3.

115 Report of the Ancillary Licences and Other Matters Committec, AJHR, 1979, I15, p. 15.

116 AL AC, Living With Alcobol: Preventing Misuse, Wellington, 1983, p. 9.

117 I I.K. Orchard, New Zealand Alcohol Consumption Statistics 1955-1989', Wellington, 1990.
} 
published figures on alcohol available for consumption. ${ }^{118}$ As can be seen, the sustained increase in liquor consumption over most of the previous 30 years came to a halt in the mid-1970s and went into reverse within a decade. It is unlikely that the increase in alcohol availability in the late 1970 s contributed to the halt in rising consumption, which levelled off several years before the changes. However, apart from the brief surge in drinking in 1978, there is no evidence that greater availability led to any increase in consumption.

Figure 6.12: Estimated Consumption of Absolute Alcohol per Person Aged 15+, 19552004, Litres

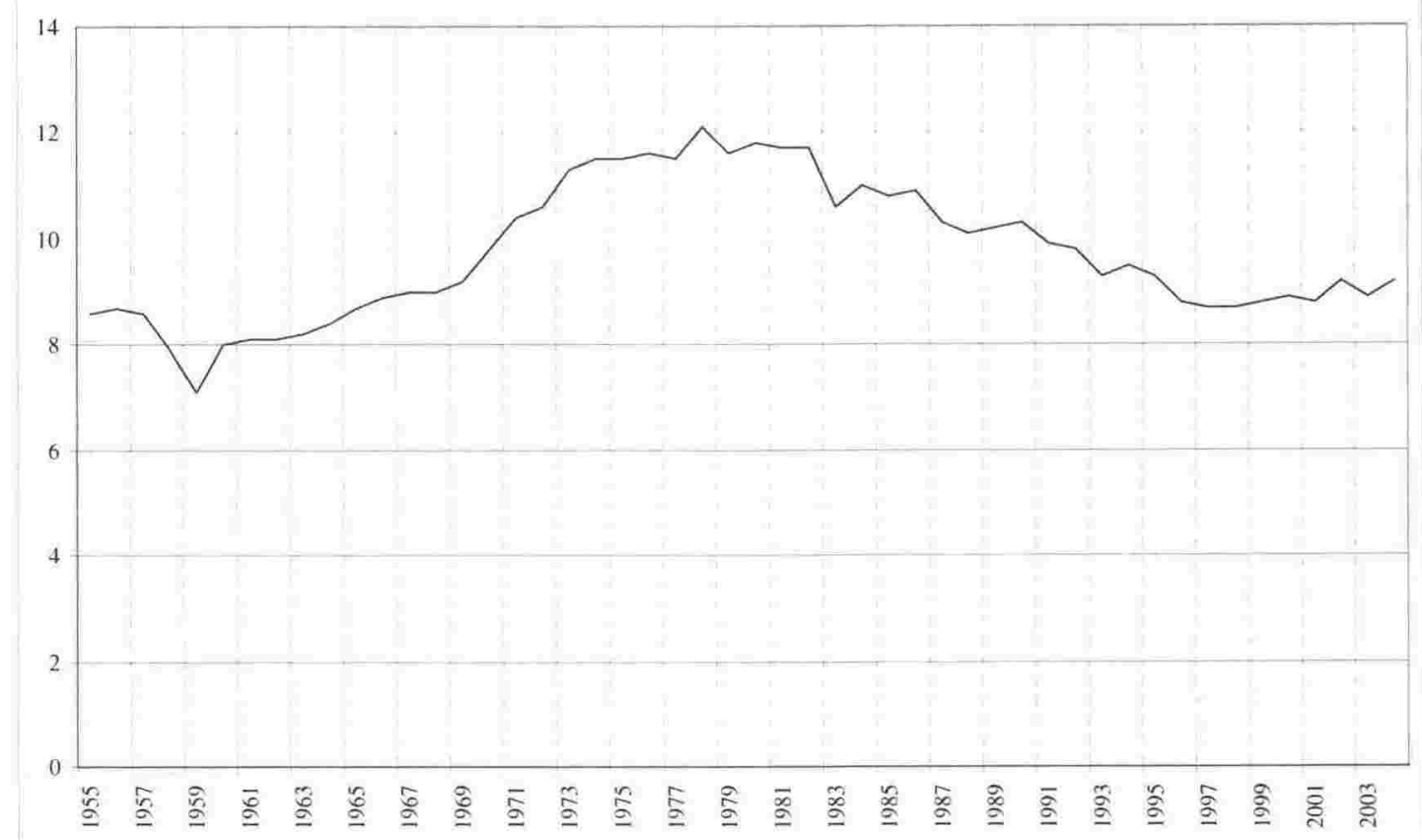

Source: Orchard, 'New Zealand Alcohol Consumption Statistics 1955-1989' and Statistics New Zealand INFOS database, Table ALCQ.SAL1

The steady rise in the number of licensed clubs came to a halt in the mid-1980s. But, as was seen in Chapter 4, the passing of the Sale of Liquor Act 1989 inaugurated the most radical increase in liquor availability ever implemented in New Zealand. The result was 64 percent increase in the per capita number of licensed liquor outlets between 1990 and 1995. The proportionate increase was roughly the same for outlets for on-premises and off-premises consumption. ${ }^{119}$ The end to legislated standard hours of sale - apart from restrictions on Sundays and some public holidays - also probably increased the availability of alcohol, After the change, the hours that each outlet could open was determined by

\footnotetext{
118 Available quarterly from the Statistics New Zcaland web site, www.stats.govt.nz.

${ }^{119}$ Department of I Iealth and AL.AC, National Alcobol Strategy 2000-2003, Wellington, 2001, p. 6.
} 
the conditions for its licence as set by local licensing authorities. ${ }^{120}$ As a result many central city bars could legally open until three am, or in some cases later. It is unlikely there was an increase in the total hours of sale, for there was no longer a requirement for bars to stay open during the hours specified on their licence. Many consequently remained closed until evening and did not open at all on some days. However there was certainly an increase in opening hours during periods of high demand, with central city bars commonly busy with patrons until the early hours of the morning.

What made the increase in liquor availability in the 1990s significant is that, unlike the post-1977 changes, there was no dispute that the increase was genuine. Few of the new outlets were sports clubs or other venues that had previously been selling liquor without a licence. The changes if anything had a downward effect on alcohol consumption, as can be seen from Figure 6.12. Annual consumption per adult fell by 14 percent during the 1990 s, a continuation of earlier trends.

Figures 6.13 to 6.15 show that falling liquor consumption in the 1990 s was driven primarily by a 27 percent drop in per capita beer consumption. Spirits consumption fell by 14 percent between 1990 and 1999, while consumption of wine increased by ten percent. Although wine consumption had already been increasing in 1990, it is likely that the sudden rise to a new level in 1991 was driven by the legalisation of wine sales in supermarkets and grocery stores. Supermarkets in particular were able to offer discount prices. ${ }^{121}$ Beer was not allowed to be sold in supermarkets until December 1999 and spirits sales remained restricted to specialist liquor outlets. ${ }^{122}$

${ }^{120}$ Sale of Liquor Act, New Zealand Statutes 1989, pp. 1256-9, 1268-9.

121 Jia-Fang Zhang and Sally Casswell, "The effects of real price and a change in the distribution system on alcohol consumption', Drug and Alcobol Review, Dec 1999, vol. 18, no. 4, pp. 371-9.

122 Sale of Liquor Amendment Act 1999, Section 30. 
Figure 6.13: New Zealand Consumption of Beer per Capita 1981-2001 (Year Ending 30 June), Litres

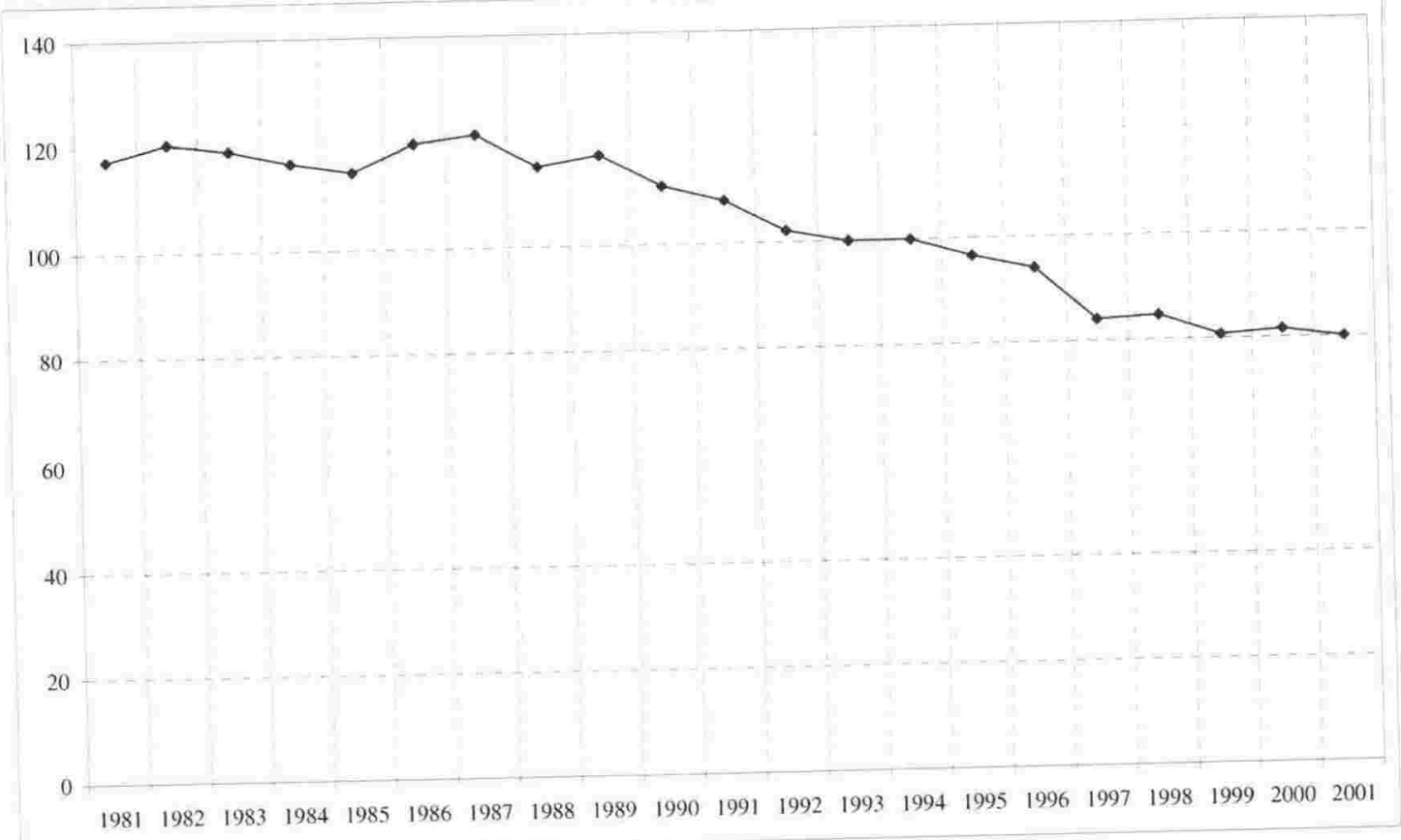

Source: World Drink Trends 2003, p. 92

Figure 6.14: New Zealand Consumption of Spirits per Capita 19812001 (Year Ending 30 June), Litres of Absolute Alcohol

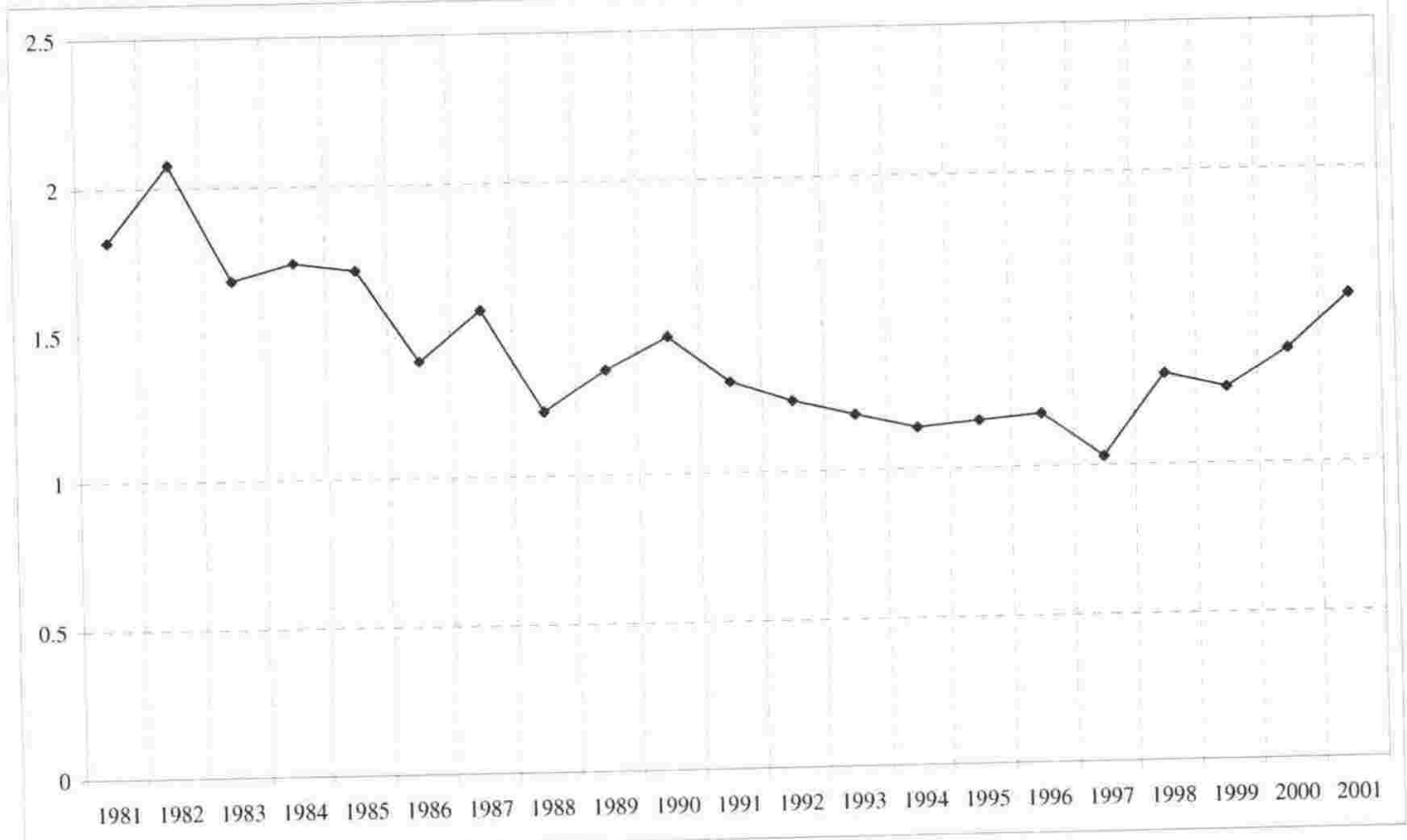

Source: World Drink Trends 2003, p. 92 
Figure 6.15: New Zealand Consumption of Wine Per Capita 1981-2001 (Year Ending 30 June), Litres

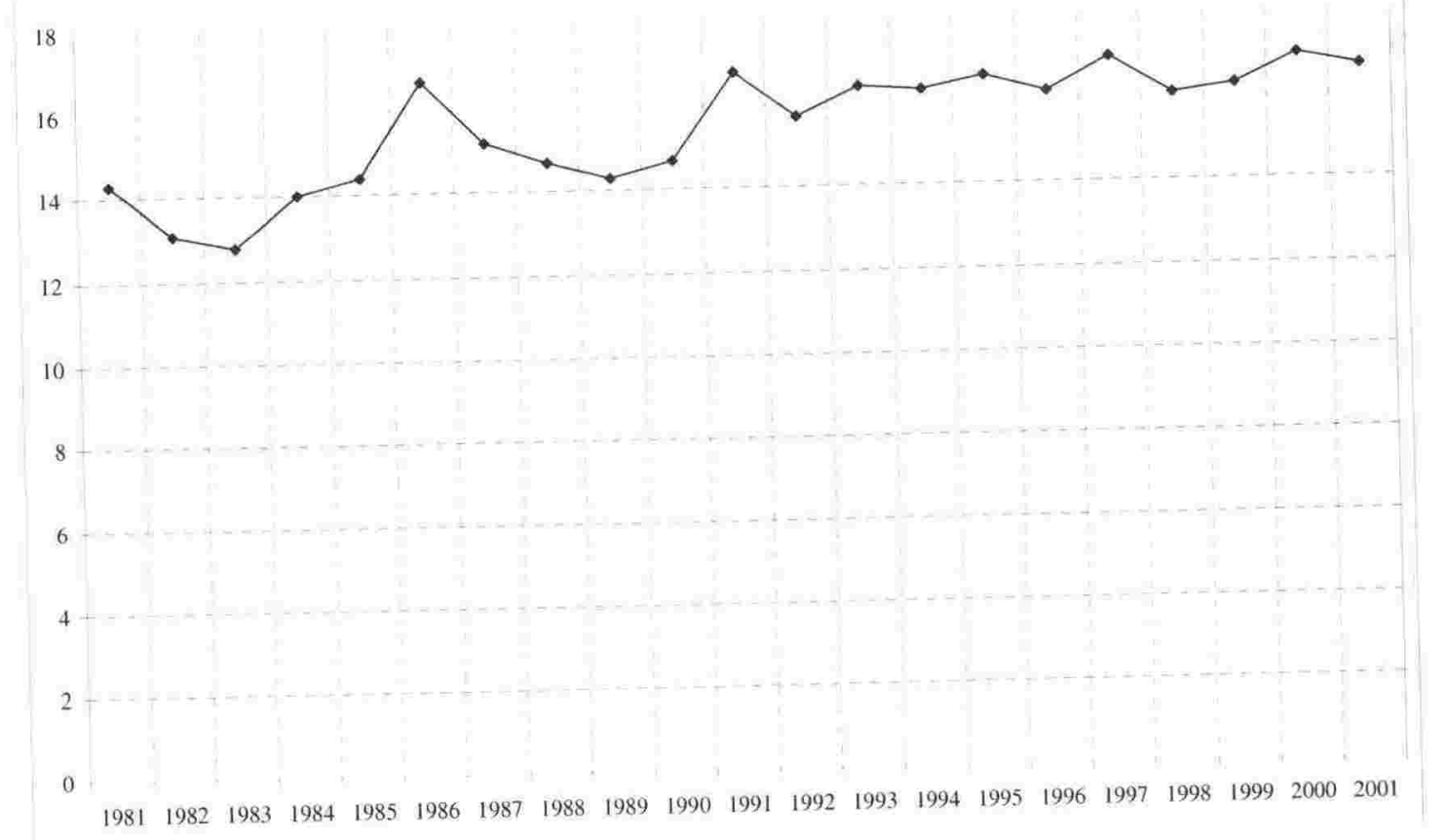

Source: World Drink Trends 2003, p. 92

There is some evidence from sample surveys of self-reported drinking that the fall in consumption may have been less than officially recorded. An annual Auckland survey found a slight increase in alcohol consumption during the decade, against the apparent national trend. The authors attributed the difference to a comparatively buoyant Auckland economy during the 1990 s and demographic changes. ${ }^{123}$ National drinking surveys conducted in 1995 and 2000 found that a slight decrease in drinking by men was matched by increased drinking by women, indicating little or no overall decrease in consumption. ${ }^{124}$ The differences between self-reported and official consumption trends may well be explained by increased international air travel resulting in greater duty free purchases that were not included in the official statistics. However, the reported differences between the two sets of statistics were not large. ${ }^{125}$ Overall, estimated per capita liquor consumption was little higher in 1999 than it had been before Arnold Nordmeyer's 1958 'black budget' significantly increased alcohol taxes. This is surprising when it is considered that in 1999 there were four times as many liquor outlets on a

\footnotetext{
123 Sally Casswell and Krishna Bhatta, A Decade of Drinking: Anckland 1990-1999, Auckland, 2001, pp. 13, 50-51.

124 Habgood ct al, Drinking in New Zealand: National Surveys Comparison 1995 and 2000, pp. 7-8.

125 Casswell and Bhatta, A Decade of Drinking, p. 50.
} 
population basis than in 1957, a time when outlets were legally prevented from selling alcohol after six pm in most circumstances.

\section{Changing the Drinking Age}

In 1910 the legal drinking age was raised from 18 to 21 . As can be seen from figures 6.4 to 6.6 , this change had no apparent effect on the rate of alcohol consumption or on drunkenness convictions, at least in the short term. This is not surprising, as there were few common forms of age identification at the time. It is unlikely that pub patrons were expected to carry their birth certificates with them. Although the first driver's licenses were introduced in 1912, motor vehicles did not become common in New Zealand until the $1920 \mathrm{~s}{ }^{126}$

The lowering of the drinking age from 21 to 20 in 1969 was followed by a sharp shortterm increase in average liquor consumption. As Figure 6.12 shows, this increase lasted about five years before consumption leveled off. It is hard to disentangle the effect of lowering the drinking age from economic effects - the ending of the recession of the late$1960 \mathrm{~s}$ and the brief economic boom of the early 1970s. However there appears to be a prima facie case that lowering the drinking age in 1969 led to increased drinking. A similar but more striking pattern occurred after December 1999 when the legal age for purchasing liquor was lowered from 20 to $18 .^{127}$ Figure 6.12 shows that liquor consumption fell by 25 percent at a fairly constant rate between 1982 and 1999 . But from 1999 the trend of the previous 17 years went into reverse and by 2004 liquor consumption per person aged over 15 had risen by nearly five percent. This casts doubt on claims that lowering the drinking age would have little effect on consumption because those under 20 previously had easy access to liquor. An alternative explanation is that other changes instituted in 1999 - Sunday liquor sales and the sale of beer in supermarkets - may have caused the turnaround. Before these changes, supermarkets and grocery stores commonly covered their wine stocks on Sundays to indicate they were prohibited goods and could not sell beer at any time. The 1999 changes would therefore be expected to result in increased beer and wine sales. In reality increased liquor consumption was driven entirely by increased spirits sales, as indicated by Figures 6.13 to 6.15 and confirmed by more recent data. The rise in spirits consumption was in turn driven by increased demand for

126 N/OYB 1990, pp. 548-9, 554.

127 Sale of Liquor Amendment Act 1999, Section 83. 
pre-mixed spirits-based drinks, sometimes called 'alcopops', a style of beverage reputedly popular with teenagers. ${ }^{128}$ Clearly it was the lowering of the drinking age, rather than Sunday liquor sales and supermarket beer, which was driving the increased demand for alcohol. It is obviously too soon to tell whether the increase in liquor consumption since 1999 is a short-term or long-term effect. ${ }^{129}$

\section{Other evidence}

The main evidence relating to tests of the availability theory through rapid changes in availability ('historical experiments') is outlined above. However there is other, admittedly less compelling, historical New Zealand evidence relating to the theory. Liquor outlets were to a large extent frozen in location after 1881. The predictable result was a major imbalance in the distribution of hotels due to demographic change. By the time of the 1926 census the South Island had 60 percent more hotels than the North Island once population size was taken into account, yet the South Island did not appear to be a hotbed of problem drinking. ${ }^{130}$ Despite its penchant for collecting statistics on drunkenness and alcohol consumption, the Alliance never claimed there was excessive drinking and drunkenness in places well endowed with pubs such as the West Coast. ${ }^{131}$ The official drunkenness figures perhaps give a clue why. In 1926 the South Island had only 3.3 convictions for drunkenness per 1000 people, compared with seven per 1000 in the North Island. ${ }^{132}$ Admittedly these differences may result from variable enforcement throughout the country, but they certainly provide no support for the availability theory.

Further doubt is cast on the availability theory by the example of the West Coast - that part of the South Island made up of the former province of Westland and the district of Buller. The West Coast stood out as an exception during the years of heavy restrictions, primarily because of its stable rather than growing population. In 1937 there were 73

\footnotetext{
128 Statistics New /caland, 'Spirits and Spirits-based Drinks Available for Consumption' in 'Alcohol and Tobacco Available for Consumption, Year ended December 2005', available from www.stats.govt.nz, accessed 18 March 2006. The figures indicate that consumption of spirits-based drinks more than doubled between 1999 and 2005 while consumption of beer, wine and spirits barely changed.

129 In 2005 the Ministry of Justice reported on some of the other effects of lowering the drinking age, Barb Lash, Young People and Aliobol: Some Statistics to 2003 and 2004 on Passible Effects of I owering the Purchase Age, Wellington, 2005.

${ }^{130}$ Report RCI., p. 198, N7OYB 1990, p. 129.

131 Onc of the members of the 1945 Royal Commission commented on this fact, Report RCL, p. 408.

132 Justice Statistics of New Zealand, 1926. 1926 was chosen because it was a census year. In addition, in the 1920s the Department of Statistics published comprehensive local court statistics that enabled these sorts of comparisons to be made. The department discontinued this practice after 1930.
} 
pubs in Westland compared with just five in Hamilton, a town with a similar total population. $^{133}$ In addition, as was seen in Chapter 5 , the restrictions on evening and Sunday sales were commonly ignored on the Coast. With its numerous pubs and long drinking hours the West Coast should have been a hotbed of drunken mayhem according to the availability theory. Yet when the LCC visited the Coast in 1951, police testimony corroborated official records showing few convictions for drunkenness or other crimes. The commission was impressed with the 'leisurely and sociable conditions' under which drinking appeared to take place. ${ }^{134}$ While this is purely anecdotal evidence, it does not appear to be contradicted by that presented to the 1945 Royal Commission. ${ }^{135}$ Again, other factors such as variable enforcement of the law and a widely-scattered population may have contributed to lower reported crime rates in on the West Coast. But as an example of a district with a traditionally lenient approach to liquor control it appears to provide no support for the availability theory.

Another piece of evidence relates to the removal of restrictions on purchasing liquor that had been placed on Maori. From 1895 Maori women were prohibited from purchasing liquor unless married to a non-Maori, and from 1904 Maori men in most parts of the North Island were prohibited from purchasing liquor for home consumption. ${ }^{136}$ These restrictions were removed in 1948, primarily because of campaigning by Maori returned servicemen who had become used to equal treatment while overseas. However a number of Maori and Pakeha witnesses who testified to the 1945 Royal Commission had wanted the controls retained. The Alliance counsel suggested that their removal would result in 'virtually unlimited drinking'. ${ }^{137}$ The removal of these controls in 1948 provides a further opportunity to test the availability theory. No surveys appear to have been done on Maori drinking habits of the time, but separate Maori figures are available for drunkenness convictions. Figure 6.11 above shows the comparative rates of Maori and non-Maori convictions for drunkenness beginning two years before the restrictions were lifted at the end of 1948. It is apparent that, if anything, the gap between Maori and non-Maori

133 PRCL, Pp. 31-2.

13. Innual Report of the licensing Control Commission, IJHR 1952, H-3, pp. 6-7.

135 See, for example Report RCI, p. 408.

136. Alcoholic liquors Sales Control Amendment Act, NZ Statutes 1895, p. 173 and NZ Statutes 1904, p. 244. The areas when Maori men were prohibited from buying takeaway liquor were gazetted from time to time, and by 1946 included the cntire North Island, Report RCL, p. 35.

137 PRC:L, p. 4430. 
drunkenness rates narrowed after the 1948 reforms. ${ }^{138}$ The ending of the ban on liquor sales in the King Country in 1954 also appears to have had no impact on drunkenness convictions.

Admittedly the main change after 1948 was to allow Maori males to purchase alcohol for off-site consumption, a change that might be anticipated to have little effect on drunkenness convictions. However if the predicted 'unlimited drinking' had resulted, some impact might reasonably be expected. The other main reform removed the ban on Maori women being served alcohol unless married to a non-Maori. In fact this change did result in an increase in drunkenness convictions for Maori women - from three in 1947 to 14 in 1949 - but the numbers are so low as to render the increase statistically insignificant. As these figures indicate, drunkenness was rarely a major problem among Maori, casting doubt on the rationale for the restrictions in the first place. ${ }^{139}$

\section{Conclusion}

The historical evidence from New Zealand at best provides mixed support for the availability theory. Sudden sharp rises in the price of liquor due to increased taxes in 1921 and 1958 appear to have led to an immediate and sustained reduction in alcohol consumption. There also appears to have been some increase in alcohol consumption following the lowering of the drinking age in 1969 and 1999, indicating that a more restrictive age law was limiting drinking to some extent. However other restrictions appeared to have no effect in reducing consumption. A halving in per capita outlet numbers between 1894 and 1910 was accompanied by rises rather than falls in alcohol consumption and drunkenness convictions. The 44 percent reduction in hours of sale after 1917 appears to have had little effect on either indicator. During the period of lessening restrictions, the end of six o'clock closing in 1967 does not seem to have led to any noticeable increase in consumption. Drunkenness convictions continued to fall, in line with earlier trends. There appears to have been more drinking and driving after 1967, but this increase proved temporary once enforcement of the drink-driving laws became stricter during the 1970 s. Any harmful effects were negated by targeting drink-drivers rather than by attempting to curtail the drinking of the entire population. The main

\footnotetext{
138 Figures are for arrest cases only. No data is available for the period 1941 to 1946.

139 For a more detailed discussion see Christoffel, 'Crime and the Maori'. While Maori generally had higher conviction rates than non-Maori for drunkenness, the differences were generally small compared with those for other crimes.
} 
downside of the end of early closing - admittedly a major one - was an increase in the rate of Maori convictions for drunkenness, although this may possibly have been linked to increasing Maori urbanisation.

The significant increase in alcohol availability from the late 1970 s onwards was accompanied by a fall rather than a rise in alcohol consumption. The increase in average consumption, which had been almost continuous since the Second World War, levelled off after 1974. From 1983 the trend reversed; people were drinking less on average each year despite the fact that liquor was becoming more accessible. Perhaps the most striking figure overall is that a 320 percent increase in the number of licensed liquor outlets per capita between 1977 and 1997 was accompanied by a 24 percent fall in alcohol consumption per person over 15. By the end of the century New Zealanders were drinking less on average than they had throughout most of the previous 50 years. Heron also noted a similar phenomenon in relation to Canada. Consumption and the incidence of drinking problems had declined in the 1980s and 1990s 'despite the exploding numbers of retail outlets and licensed establishments and the longer hours of operation in both,. ${ }^{140}$

It is perhaps pertinent to conclude by returning to the example of Finland discussed earlier in this chapter which seemed to provide such a striking confirmation of the availability theory. To recap, Finnish reforms introduced in 1969 led to a sudden and significant increase in liquor outlets numbers and a corresponding significant increase in alcohol consumption. So why did the large increase in outlet numbers in New Zealand in the 1990s not produce similar results? An analysis of the Finnish situation reveals considerable differences between the two cases. Finland's strong temperance movement had resulted in alcohol being prohibited between 1919 and 1932. After 1932 alcohol sales were allowed only through a small number of state liquor stores (132 in 1968) and in licensed restaurants (940 in 1968)..$^{141}$ Prohibition largely remained in place in rural districts; in 1968 nearly half the population lived in areas where liquor stores were not permitted. $^{142}$ One result of this temperance and restrictionist tradition was a high level of abstinence. A 1968 survey found that 32 percent of Finnish adult women had never

\footnotetext{
149 I Ieron, Boaze, p. 368.

$1+1$ Makela et al, 'Who drinks more and less when policies change?' p. 22.

142 Dan F. Beauchamp, "Ihe Paradox of Acohol Policy: 'The Case of the 1969 Nlcohol Act in Finland' in Mark H. Moore and Dean R. Gerstein, eds, Alcohol and Public Poligy: Beyond the Shadow of Prohibition, Washington, 1981, p. 232.
} 
consumed alcohol. ${ }^{143}$ In this environment the authorities suddenly allowed beer to be sold through 17,431 grocery stores and 2716 cafes. The ban on rural liquor outlets was ended and restaurant numbers increased by 46 percent within a year as licences were made easier to obtain. ${ }^{144}$ The legal drinking age was lowered from 21 to $20{ }^{145}$ Significant social change was already underway even before the reforms of 1969, as shown by the 1966 election of a leftist government. Real incomes were rising strongly and the country was urbanising rapidly. Between 1962 and 1968 the per capita consumption of beer and wine had already doubled, although spirits still accounted for half of all consumption of absolute alcohol. Increased liquor consumption was evident across a number of industrialised countries at the time. ${ }^{146}$ It is therefore hardly surprising there was a significant increase in liquor consumption following the 1969 reforms. This increase was driven largely by a 224 percent rise in beer consumption in one year. Per capita alcohol consumption by women doubled and by 1976 just 15 percent had never consumed alcohol. $^{147}$ There are therefore a number of factors that justify treating Finland as something of an outlier as a test of the availability theory. These include its legacy of absolute and semi-prohibition; the social and economic environment in which the 1969 reforms were made; and the sheer magnitude of the changes, including a lower drinking age and beer suddenly becoming available through some 20,000 outlets rather than $132 .{ }^{148}$ Beauchamp speculated that, in a country where spirits were traditionally the drink of choice, beer must have seemed almost non-alcoholic. ${ }^{149}$

The Finnish comparison possibly shows that, despite the seeming radical nature of New Zealand's restrictions on outlet numbers and hours of sale, these restrictions were too mild to have an effect on alcohol consumption. Extreme restrictions such as those imposed in Finland may well have had some effect. The next chapter speculates as to why New Zealand persisted with its comparatively more moderate restrictions despite the evidence against them.

\footnotetext{
${ }^{1+3}$ Beauchamp, Taradox', p. 244.

${ }^{4}$ Makela et al, 'Who drinks more and less when policies change?' p. 22.

145 Beauchamp, 'Paradox', p. 232.

146 Bcauchamp, 'Paradox', pp. 233, 240-2.

147 Beauchamp, 'Paradox', pp. 233, 235, 244.

148 This is a large number given that the population of Finland has been only slightly higher than that of New Zealand during the post-war period.

149) Beauchamp, Taradox', p. 232.
} 


\section{Chapter 7}

\section{THE EFFECT AND PERSISTENCE OF CONTROLS}

Public health theorists commonly acknowledged that availability restrictions may inconvenience drinkers. However this was considered to be a good rather than a bad thing, for inconvenience will reduce temptation and therefore supposedly lead to lower alcohol consumption. But as was seen in Chapter 6, restrictions on opening hours and outlet numbers did not appear to have had any noticeable effect on liquor consumption in New Zealand. Furthermore the effects of restrictions - including a ban on sales in some areas - often amounted to more than mere inconvenience. This chapter argues that, not only did these restrictions fail to produce the expected positive results, they had social effects that were actually detrimental. It also discusses why restricting the physical availability of alcohol did not appear to lead to less drinking. Finally it briefly speculates as to why the restrictions were retained for so long. It was argued in earlier chapters that regular repetition of liquor polls and the belief that restricting access to alcohol would lead to reduced consumption were important reasons, but other factors such as New Zealand's relative isolation may also have made a contribution.

Those countries that attempted to ban alcohol despite its popularity did not prohibit it for long. Prohibition officially lasted for 13 years in Finland and the United States. Of the ten Canadian provinces and territories that went dry in the early twentieth century, seven went wet again within a decade. ${ }^{1}$ The widespread lawbreaking and other consequences that made prohibition unpopular are well documented. ${ }^{2}$ New Zealand's experiment with a much more restricted form of prohibition lasted considerably longer. From 1909 until 1950 as much as 20 percent of the population lived in districts in which the sale of alcohol was illegal. ${ }^{3}$ The spread of no-licence would seem a significant victory for the prohibition movement, but the picture was less rosy for prohibitionists than it appeared. A third of

\footnotetext{
II leron, Booze, p. 170.

2 See, for example, I Ieron, Booze, pp. 235-268.

3 The total population in no-licence and special districts would have varied with population shifts and electoral boundary changes, so the 20 percent is simply an estimate of the likely upper extent of no-licence coverage. In 1945 for example, 17 percent of the population lived in dry districts despite Invercargill having gone wet two years earlier. This figure excludes 'special' and proclaimed dry areas such as Ashburton and the King Country, Report RCL, p. 198.
} 
the original dry electorates were in the suburbs of Wellington and Auckland where most residents had relatively easy access to alcohol elsewhere in the city. It is in the remaining dry districts, comprising small towns and rural areas, that no-licence had its greatest impact in the first half of the twentieth century. A relatively small proportion of the population lived in such districts during the dry heyday; perhaps ten percent given the country quota that was in place until $1945 .^{4}$ Furthermore, even in provincial districts nolicence was less restrictive than might be thought. There was no ban on possessing liquor and supplying it to guests, only on its sale. Individuals could import alcohol into the district in quantities of at least two gallons, although there were requirements, often ignored, that such imports be declared to the authorities. ${ }^{5}$ For example in the first year of prohibition in Mataura, nearly 38,000 gallons of beer and over 7000 gallons of spirits were railed into the electorate. ${ }^{6}$ Undeclared imports were of course not accounted for in these figures. In 'dry' Invercargill, 265,000 gallons of beer and 14,700 gallons of whiskey were legally imported in the three years 1912 to $1914 .^{7}$

From the time Clutha went dry in 1894 there was an ongoing debate about the virtues and vices of no-licence. Supporters of no-licence drew attention to the fall in convictions for drunkenness and other crime in no-licence districts, despite the continued significant importation of liquor into dry towns. ${ }^{8}$ For example, in the Invercargill electorate drunkenness convictions fell by 38 percent in the first two years after the introduction of no-licence compared with the two years before.' Drunkenness convictions increased again in later years but to nothing like the previous levels. ${ }^{1 "}$ Some were sceptical of such improvements, pointing out that the national rates of drinking, drunkenness and crime were increasing despite the spread of dry districts. 'If more drink per head of the population is being consumed what does it matter whether men consume the drink in Ashburton, or go to outside districts, and buy and consume it there,' long-term Ashburton

\footnotetext{
+ In 1945, for example, less than seven percent of the population lived in non-urban dry districts, although this figure excludes the King Country and special districts, Report RCL, pp. 34, 198. The country quota meant rural clectorates had fewer voters than urban ones.

5 Report RCI, p. 35

6. AJHR 1905, H29-A.

7 . IJHR 1913, H-30, 1914, H-28, 1915, H-28.

${ }^{8}$ See, for example, Reeves, State Experiments, volume 2, pp. 315-317; Jim I Iarris, Is No-License a Success?, Wellington, 1910, pp. 8, 12, 14, 20; Adams, Professor Salmond's Blinder, pp. 77-9.

9. AJHR 1909, H-29A.

${ }^{10}$ Department of Statistics, Statistics of New Zealand, 1901 to 1916, figures from Magistrates Courts convictions.
} 
resident John McKeague wrote in 1905. ${ }^{11} \mathrm{He}$ and others claimed that no-licence had 'driven many who formerly made their frequent appearances in the Magistrate's Court from no-licence Ashburton into other districts. ${ }^{12}$ In other words dry districts were simply pushing their problems onto other areas.

There may have been truth in such claims. For example Invercargill was surrounded by the wet electorate of Awarua, which had 19 hotels that were generally within easy reach of the town. ${ }^{13}$ Riverton in the wet district of Wallace was also nearby. A better measure of the effect of no-licence is therefore its impact, not just on Invercargill but also on surrounding districts. Relevant arrest figures after 1902 are available for the Southland police district, which included a mixture of wet and dry areas. The dry areas included the electorates of Invercargill and Mataura plus Tapanui and Clinton in no-licence Clutha, while the wet areas included Awarua and Wallace (both close in Invercargill) plus Queenstown and Arrowtown. Drunkenness charges in the Southland police district are outlined as a percentage of the New Zealand total in Figure $7 .{ }^{14}$

Mataura's 15 pubs closed in July 1903 and Invercargill's 16 pubs closed in July 1906. ${ }^{15}$ No-licence in Invercargill was followed by a dramatic decline in arrests for public drunkenness in the police district over the next three years. However the improvement was short-lived, for drunkenness increased again relative to the national total after 1909 . The extent of the decline in drunkenness arrests after 1905 was also exaggerated by a relative decline in Southland's population, which fell from 6.2 percent of the national total in 1901 to 5.1 percent in $1921 .{ }^{16}$ The lower drunkenness rates may also have resulted in part from the shifting of drunken activity away from predictable areas such as hotels and an increased share of police resources going into detecting sly grogging - as indicated by annual police reports - leaving less time for the pursuit of other crime. ${ }^{17}$ Overall no-

\footnotetext{
"John McKeague, Probibition or No License in New Zealand: Its Real Effects, Sydney, 1905, p. 15.

12 McKeague, Probibition or No License in New Zealand, pp. 17-18.

${ }^{13}$ Report RCI.,p. 197.

1+ This was renamed the Invercargill Police district in 1904 but the Southland title will be used here to avoid confusion.

15 Cocker and Murray, p. 271. Five wholesalers also closed down in Invercargill but transferred their licences elsewhere and continued to take delivery orders from offices within the town, Harris, Is No-License a Success?, p. 3 and De la Mare, Drink or Drought, p. 74.

10 Population Census 1921, p. 12. Population adjusted figures were not used because the Southland police district appears to have covered a different geographical area than Southland province.

17 AJI IR II-16, 1907-1910.
} 
licence appears to have made Southland a more sober place, but not to the spectacular degree that its supporters may have hoped.

\section{Figure 7: Drunkenness Charges in Southland Police District as Percent of New Zealand Total, 1903-1919}

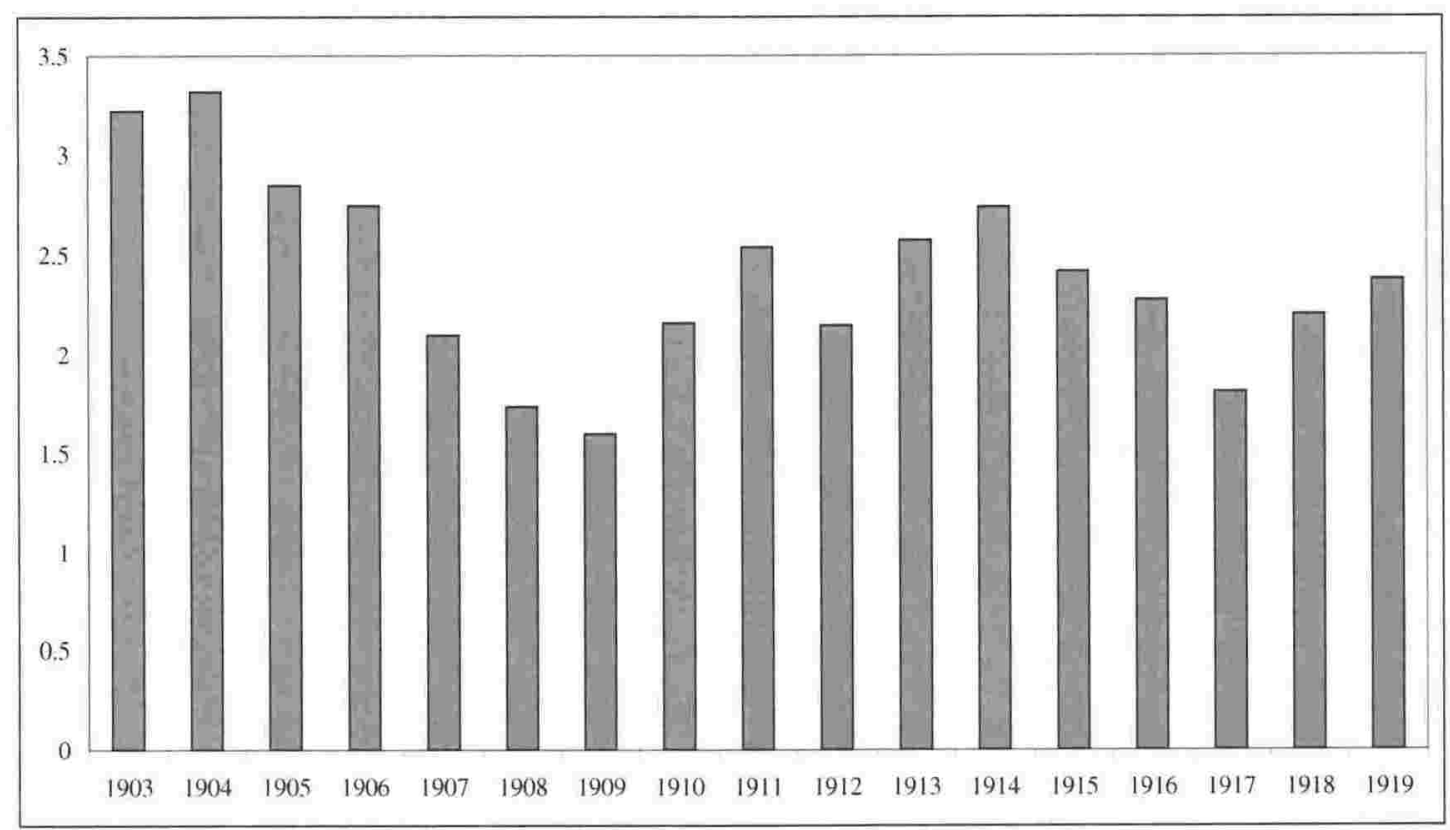

Source: Police Annual Reports 1904-1920

While there were positive aspects to no-licence, there were also negative aspects. Of the provincial dry districts, all but Ohinemuri banned alcohol sales for at least 38 years, but the apparent popularity of no-licence was deceptive. ${ }^{18}$ It was kept in place by minority vote in Invercargill, Masterton and Mataura after 1925, while the residents of special and proclaimed areas had no ability to vote to restore licences. Oamaru was the only electorate outside of suburban Auckland and Wellington in which the majority of voters continued to support no-licence after $1935 .{ }^{19}$ Strong minority opposition to no-licence caused problems from the outset. The 1898 Royal Commission on the Police Force noted particular problems in the dry districts of Clutha and the King Country, which were allegedly riddled with illegal stills, sly grog selling and unwilling witnesses. ${ }^{20}$ A Tapanui constable testified that the main problem in enforcing the ban on liquor sales in Clutha

\footnotetext{
18 Ohinemuri was dry from 1909 to 1925, Cocker and Murray, p. 272.

${ }^{12}$ Report RCI, pp. 209-10.

20 'Report and Fividence of the Royal Commission on the Police Force of New Zealand', IJHR 1898, H-2, pp. xxiii and xxiv.
} 
was the unpopularity of the law. ${ }^{21}$ An 1896 royal commission in Canada heard similar evidence about the law enforcement difficulties in no-licence areas. ${ }^{22}$ In every police annual report from 1900 to 1911 the Commissioner of Police bemoaned the difficulties of successfully apprehending and convicting sly-groggers in dry districts. His 1900 report said it was 'futile to attempt to enforce a law which has not the respect of a large percentage of the population'. ${ }^{23}$ He claimed that witnesses would not assist the police unless first promised employment in the force or were rewarded in other ways. ${ }^{24}$ In 1904 , for example, the police paid $£_{385}$ for evidence against those accused of illegal liquor sales. ${ }^{25}$ Juries in sly grog cases would often not convict on the evidence of informers who were paid or otherwise rewarded. In 1901 the Commissioner reported that 'difficulties experienced in former years in obtaining evidence in sly-grog cases still maintain, and it is only by very considerable expenditure, and with recourse to methods which are repugnant alike to a large majority of the public, the police, and those who assist the latter, that the necessary evidence to warrant prosecutions has been obtained'. ${ }^{26}$ In 1907 the commissioner described the work of catching sly-groggers as 'disagreeable and demoralising. ${ }^{27}$ Somewhat illogically the police often called for increased penalties for illegal sales - illogical because greater penalties would increase the efforts of sellers to evade detection and further reduce public co-operation in prosecutions. ${ }^{28}$ After again lamenting the lack of public co-operation in 1910 and 1911 the commissioner desisted his complaints and prosecutions dropped thereafter. Either sly-grogging had diminished or, as is more likely, the police had reduced the resources they devoted to detection. In 1988 a Dunedin student interviewed former police and sly-groggers about the battles of earlier decades to enforce and evade no-licence in Invercargill. ${ }^{29}$ The police appear to have been far from victorious in the contest. A police inspector testified to the 1945 royal commission that he had become so frustrated with the problems of law enforcement in

\footnotetext{
21 'Report and Evidence of the Royal Commission on the Police Force of New ' Kealand', p. 348.

22 I Ieron, Booze, p. 162.

23 Annual Report of the P'olice Force of the Colony, (Police Annual Report), AJI IR 1900, I I-16, p. 3.

${ }_{24}$ Police Innual Report, IJHR 1900, H-16, p. 3.

25 'Sly-Grog Sclling', AJHR 1904, H-29.

26. Police Annual Report, AJHR 1901, H-16, p. 2.

${ }_{27}$ Police Annual Report, AJI IR 1907, II-16, p. 4.

${ }^{28}$ See, for example, Police Annual Report, AJHR 1901, H-16, p. 3.

29 Janette Mollison, "Ihe 38 Year Drought: Prohibition in Invercargill 1906-1943', a Research Fissay completed for the Postgraduate Diploma in I Listory, University of Otago, 1988, pp. 58-64.
} 
dry Invercargill that he would consider leaving the country if prohibition was ever introduced in New Zealand. ${ }^{30}$

There is evidence that no-licence distupted the social cohesion of districts in which it applied. In 1897 a stipendiary magistrate in the Clutha district wrote a short report alleging 'dissension and ill-will and mutual distrust, and even hatred springing up in these little townships' after three years of no-licence. He also made claims of perjury, juries refusing to convict and 'the wide public feeling of antagonism to the law'. ${ }^{31}$ In 1904 'disturbances' were renerted at a trial of slv-groggers in Ashburton, which police attributed 
by no means an uncommon sight to see a number of young fellows collected round a keg on the roadside, or in an adjourning paddock, some of them showing signs of excessive drinking,' the Inspector of the Invercargill Police District reported in 1907. ${ }^{39}$ This development had the added disadvantage from a temperance perspective that there were few checks on the age of those doing the ordering and the entire contents of the keg were usually consumed at a sitting. Keg parties in dry districts were identified as an on-going problem when the royal commission sat in $1945 .^{40}$

While there is ample evidence of illegal alcohol sales in rural dry districts, this does not appear to have led to violent turf wars between rival sly-groggers. In Auckland the situation was different. When the boundaries of dry districts were frozen in 1945, over 40 percent of Aucklanders lived in districts where it was illegal to sell alcohol. ${ }^{41}$ The city grew dramatically after the Second World War, with the population more than doubling to nearly 550,000 between 1945 and $1966 .^{42}$ Although the number of hotels increased slightly from 80 to 98 , they were largely confined to the central city area. ${ }^{43}$ Six o'clock closing and the dearth of suburban pubs meant most Aucklanders had limited legal access to alcohol during their leisure hours. One result was the flourishing of syndicates involved in illegal alcohol sales, a trend that led to at least one significant violent incident. In December 1963 the machine-gun execution of two Remuera sly-groggers by members of a rival syndicate attracted national headlines. ${ }^{44}$ For a brief month the gang warfare of prohibition-era Chicago seemed to have come to Auckland.

Outside of dry districts availability restrictions were less stringent but their negative social effects were at least as apparent, as Bollinger outlined at length in 1959. Bars were frequently overcrowded because of their scarcity and limited opening hours, and drinks were often downed with excessive haste due to the early closing time. Lack of competition meant that minimal facilities needed to be provided by publicans, even to the extent that they removed tables and chairs from bars. These simply took up space that

\footnotetext{
39 Police Innual Report, IJHR 1907, H-16, p. 11.

${ }^{40}$ Report RCI.,pp. 223-4.

${ }^{41}$ In 1945 the total population of Auckland's four dry districts was 110,718, calculated from Report RCl, p. 19. The Auckland urban area had a population of 263,370, N7.OYB 1947-9, p. 33.

42 'The population rose from 263,370 in 1945 to 548,293 in 1966, New \%ealand Census of Population and Dwellings 1966, volume 1,p. 4.

${ }^{43}$ Report RCI.,p. 197 and I icensing Control Commission Innual Report 1966, AJHR 1966, H. 3, p. 21.

" New Zealand Police, 'Operation Machine Gun - Walker and Speight murders'; www.police govt.nz/operation/machinegun, accessed 3 December 2004.
} 
could be occupied by additional customers, who rarely wanted to sit anyway given the limited time available. The social life of the country was affected too, with places of social interaction often closed during leisure hours and licensed restaurants prohibited by law. Gender separation was exacerbated, as women rarely visited bars due to the unpleasant surroundings and their presence was probably unwelcome to publicans anyway, as they drank little and occupied valuable space. It became a commonplace misconception that women were excluded by law from public bars. ${ }^{45}$

Bollinger described the typical public bar of the 1950s as being in many aspects 'rather like a public lavatory', devoid of furniture apart from the serving counter, and with the customers 'packed into the area between bar and walls at the rate of about one person per square foot, and standing shoulder to shoulder, elbowing past one another, reaching over one another's heads, and spilling brimful glasses over one another's clothes'. ${ }^{46}$ Anecdotal evidence from other sources confirms this picture. Perhaps the best of this comes from the voluminous proceedings of the 1945 Royal Commission on Licensing, which provided a useful snapshot of drinking conditions some 27 years after the last significant change to the Licensing Act in 1918. Some of this evidence has already been described in relation to six o'clock closing, with animal analogies being commonly used by witnesses. Others were more restrained in their language. The Auckland Trades Council submission stated that 'those who wish to partake of a glass of beer... are forced to stand shoulder to shoulder in a gloomy, badly lit, ill ventilated bar the size of which is totally inadequate for the number of people to be catered for. ${ }^{47}$ The dirtiness of bars was an issue for many witnesses. $^{48}$ The prevailing drinking conditions, submitted the Department of Health, involve hazards to health from overcrowding, excessively rapid consumption of alcohol, and lack of proper hygiene standards in the washing of drinking utensils' ${ }^{49}$ A submission on behalf of a number of Wellington residents alleged that 'indignities, squalor, dirt, [and] lack of hygiene' were associated with most hotels. ${ }^{50}$

\footnotetext{
45 NZOYB 1990, p. 566.

${ }^{46}$ Bollinger, 1959, pp. 11-12.

${ }^{47}$ PRCL, p. 2736.

48 Sec, for example, PRCl pp. 1815, 1830, 2736.

49 PRCl, p.345.

50 PRC.L, p. 1847.
} 
The custom quaintly known as 'vertical drinking' was the subject of numerous submissions. Witness after witness complained of the lack of tables and chairs in bars. The trade for its part was determined to demonstrate that vertical drinking was an entrenched national custom. They even went so far as to place a spy in an Invercargill Licensing Trust bar to tally how often the tables and chairs supplied were actually occupied. ${ }^{51}$ The police and some publicans argued that vertical drinking made it easier to enforce the law against serving intoxicated persons - although as one witness pointed out, detecting drunkenness with the amount of congestion typical in bars was somewhat problematic. $^{52}$

The drinking habits of New Zealanders and their alleged frequent drunkenness were the subject of unfavourable comparisons by some of the witnesses who had lived or travelled abroad. Although restricted bar numbers and drinking hours were supposedly in the interests of temperance, a number of witnesses disputed that they had that effect. A former expeditionary force sergeant said the speed with which New Zealand boys downed glasses of beer was greeted with amazement overseas. ${ }^{53}$ Former airman Francis Greenaway claimed that drunkenness was almost unknown in European countries, whereas New Zealand has the unhappy reputation of having drunks rolling out of pubs into the public streets at six o'clock'. ${ }^{54}$ A German engineer who had lived in Wellington for six years claimed that in Germany and Italy 'there is scarcely any evidence of drunkenness in the streets at all. Scenes like Saturday afternoon in Willis Street are quite unknown'.55 A Rotorua vicar testified that overseas visitors had described the bar at the Grand Hotel as a 'hog-pen' and a 'pig trough,. ${ }^{56}$ Another witness provided hearsay evidence that the lasting impression of two Canadians after several years in New Zealand was 'the number of drunks in the streets. ${ }^{57}$ Such observations received support from some MPs when the report of the Royal Commission was finally discussed in Parliament over a year after its release. 'One will see more drunkenness in New Zealand in one week

\footnotetext{
51 PRCL, p. 2159. The day of the week for the observations was not recorded, but it was presumably a Saturday.

52 PRCI, p. 1756.

53 PRCL, p. 3075.

5t PRCl, p 1526.

${ }_{55}$ PRCL, p. 1859. The reference to Saturday afternoon is probably in relation to the closure of pubs on Saturdays from two to four pm as a temporary wartime measurc.

5 PRCL, p. 4602.

57 PRCL, p. 1534.
} 
than one will see in a year in other countries,' said one National member. ${ }^{58}$ One important witness disputed allegations about the rowdy nature of New Zealand bars. Despite his criticism of the swill, Police Commissioner James Cummings testified that 'the conduct of licensed houses in New Zealand compares more than favourably with America, Canada, England and Scotland'. ${ }^{59}$ However he was almost a lone voice in this respect, and even Justice under-secretary Berkeley Dallard spoke (rather exaggeratedly) of men ' 18 deep at the counter'."

Foreign visitors and immigrants became more common in the decades after the Royal Commission's hearings. So did their comments on local drinking habits, a fact noted by the LCC. ${ }^{61}$ An academic who immigrated in 1958 later wrote that the drinking laws and habits of the time were 'a manifestation of national brutishness which never failed to astonish and disgust overseas visitors. ${ }^{62}$ One such visitor was David Ausubel, a psychologist with an admittedly jaundiced view of New Zealand social habits when compared with his native America:

Public drunkenness in bars is more noticeable, and the number of inebriated individuals who pour out of the pubs at closing time and weave through the streets is astonishing. Similar exhibitions in the United States are more typically restricted to the slum areas of large cities....Men stand four and five deep in the public bar, and within the space of an hour swill as much beer or liquor as they would ordinarily consume in the course of three or four hours - and with correspondingly more violent results. ${ }^{63}$

Visitors also noted the effect on the country's social life of restricted pub opening hours and lack of facilities such as licensed restaurants. In 1947 the Auckland Star interviewed disgruntled English immigrants returning home on the liner Wairangi. 'Life here is a succession of Sundays,' said one woman. A male passenger wondered 'how New Zealanders manage with this six o'clock closing of public houses'. ${ }^{64}$ The following month the Star carried an interview with visiting variety star Ella Shields, who noticed boys in the

\footnotetext{
58 NZPD 1947, volume 278, p. 709-10. The discussion was delayed for so long due to the intervention of a General Election and the resources needed to print a copy of the 450 page report for each MP.

59 PRCL, p. 1177.

${ }^{60}$ PRCL, p. 989.

${ }^{61}$ I.CC Innual Report, NJHR 1962, H.3, p. 4.

${ }_{62}$ John Gould, The Rake's Progress? The New Zealand Economy Sinee 1945, Auckland, 1982, p. 67.

63 Ausubel, The Fern and the Tiki, pp. 51-2.

of The Awckland Star, 16 August 1947, p. 1.
} 
streets after six pm clutching 'parcels of beer'. 'What is needed is some place where they can sit down in the evening and drink like ladies and gentlemen. ${ }^{35}$ British writer Eric Linklater wrote after his 1951 visit that 'the restaurateur is by law strangled in his infancy' and that pubs closed 'about the hour that little boys should be put to bed'. ${ }^{66}$ It was not just foreigners who said such things. 'New Zealand is a fairly dull place after six o'clock in the evening,' an MP told parliament in 1949. 'There is little to do, and little social activity. There are few amenities existing except the pictures, and everybody does not want to go to the pictures. ${ }^{967}$ Delegates at an annual meeting of tourist industry representatives in 1955 condemned the poor impression that the daily outpouring from the pubs at six pm gave to overseas tourists. ${ }^{68}$

Later decades brought social problems of a different sort. As was noted in Chapter 4, the restrictions on new outlets led to the development of booze barns with their impersonal cavernous spaces packed with drinkers, sometimes resulting in violent confrontations. The large car parks in such establishments were also alleged to encourage drinking and driving. Temperance advocates were appalled by booze barns but did not appear to connect their emergence with the ongoing stifling of consumer choice and the perpetuation of dry districts.

\section{Why Access Restrictions Failed}

It was seen in Chapter 6 that of the various restrictions imposed on the availability of alcohol in New Zealand, the only one that unambiguously led to reduced alcohol consumption was the imposition of large tax increases on liquor. Given the lack of obvious legal substitutes for alcohol, once it became more expensive many people chose to cut back on consumption. ${ }^{69}$ The alternatives were to cut back on other items of discretionary expenditure, reduce their savings, or some combination of these. As orthodox economic theory would predict, some people also switched to wine, an alcoholic beverage that was not affected by the tax rises in 1958 .

\footnotetext{
65 The Auckland Star, 19 September 1947, p. 4.

(6) Quoted in Mcl auchlan, The Story of Beer, p. 137.

67 N'ZPD 1948, volume 283, p. 4247.

68 The Dominion, 23 Nay 1955 , p. 8.

${ }^{69}$ The main legal substitute is home production, although this still has a cost in time and money.
} 
It would also seem to follow from orthodox economic theory that people will consume less alcohol if restrictions are imposed on its physical accessibility. Such restrictions should result in increased transaction costs that will suppress demand. However transaction costs do not involve a straightforward increase in the financial cost of purchase. They involve costs in the form of time and convenience that are more difficult to quantify and easier to avoid. For example the potential inconvenience of restricted outlet numbers and hours of sale can be avoided by buying liquor less frequently and in bulk. It is far from certain that such changes in behaviour will lead to less alcohol being purchased except in the case of acute restrictions such as prohibition. ${ }^{70}$ But in relation to lesser restrictions the evidence from New Zealand clearly shows that people were not deterred from the temptations of drink in the way that the availability theory would predict. In fact the theory seems to make slightly inconsistent claims regarding drinking behaviour. Some modern-day advocates of the availability theory have argued that, because drinking is a social activity, drinking habits tend to spread throughout the population due to social contagion. This factor is used to explain how an increase in the average level of consumption appears to be reflected in increased drinking by people on all points of the consumption continuum, regardless of whether they are moderate or heavy drinkers. However the assumption that reducing availability will reduce demand makes little allowance for this social aspect of drinking. Instead it appears to assume that drinking is commonly an impulse activity - the mere sight of numerous bars open during leisure hours will tempt those to enter who had previously not considered doing so. Alternatively, those who might have considered imbibing will be deterred by the inconvenience imposed by restricting outlet numbers and hours of sale. Thus, rather than their drinking behaviour being influenced by those around them, people's drinking behaviour is influenced by convenience of access.

It is argued here that the social nature of drinking can be a significant influence on people's consumption and that restricting physical availability may not therefore greatly reduce the amount of liquor consumed. People commonly fit drinking into their regular routine, such as a Friday or Saturday night, or will drink on special occasions such as birthdays, work celebrations, weddings, or when they have guests for dinner. In countries

\footnotetext{
70 Is was seen in the introductory chapter there is strong circumstantial evidence that the imposition of prohibition in the United States reduced average alcohol consumption, as shown by the reduction in cirrhosis mortality, Dills and Miron, 'Ncohol Prohibition and Cirrhosis'. 'l'here is also somewhat weaker evidence outlined above that the banning of liquor sales in dry areas such as Invercargill led to less drinking.
} 
like New Zealand where local neighbourhood pubs are rare, they may organise to meet friends for a drink at a specific time and place, dine out at a restaurant, invite them into their home, or gather for a party. Couples may share a bottle of wine with dinner. Admittedly a portion of consumption is unplanned and impulsive and it could be argued that the ready availability of alcohol in supermarkets and grocery stores encourages impulse buying. In fact one study concluded that the introduction of wine in New Zealand supermarkets did lead to an increase in wine drinking. However this was matched by a decrease in beer and spirits consumption and there was no increase in alcohol consumption overall. It appeared that supermarkets were able to influence consumer choices through lower wine prices without leading to increased drinking. ${ }^{71}$ Widespread availability may also discourage the bulk purchase and stockpiling otherwise needed to ensure continuity of supply.

It is therefore argued that restricting access to alcohol may do little or nothing to ensure that people will in general drink less. A more likely response, at least in societies where alcoholic beverages are already popular, is a change in drinking habits and behaviour to fit in with or circumvent the controls. There is abundant evidence that this was the case in New Zealand. People responded to the restrictions in a variety of legal and illegal ways. As noted in relation to six o'clock closing, common responses were to buy liquor frequently and in bulk to ensure continuity of supply, drink more quickly in the limited time available, drink during the daytime, and to evade or ignore the legal restrictions. In dry areas where alcohol sales were not permitted at all, greater enterprise was often required by those wanting to continue their drinking activities. People commonly travelled to a neighbouring wet district for their regular drinking sessions - pubs near Invercargill reputedly did great business after the town went dry in $1906 .^{72}$ As previously noted, alcohol could legally be imported into dry districts in quantities of at least two gallons providing the police were notified. Keg parties thrived in the absence of bars. Sly grogging - the illegal sale of liquor - also became common in rural no-licence districts. Instead of Irish style 'shebeens' that acted as illegal bars in Canada during the period of significant liquor restrictions, semi-formal but illegal social drinking clubs emerged in dry districts. ${ }^{73}$ In the country at large, clubs became increasingly common venues for drinking

\footnotetext{
71 Jia-Fang Zhang and Sally Casswell, The effects of real price and a change in the distribution system on alcohol consumption', Drig and Aliobol Review, Dec 1999, vol. 18, no. 4, pp. 371-9.

${ }^{72}$ De La Mare, Drink or Drought, p. 76.

73 I Teron, Booze, pp. 162, 252-3, 293-4 and NZPD 1948, volume 284, pp. 4246-7.
} 
with the on-going freeze on new hotel licences. The Royal Commission on Licensing described the operation of the 'locker system' in sports and other non-chartered clubs that provided a legal loophole that could act as a cover for illegal sales. ${ }^{74}$ The authorities tended to ignore any transgressions of the somewhat hazy laws pertaining to clubs, which were commonly frequented by the middle classes. 'Most of us belong to clubs and most of us know that alcoholic liquor is being consumed in clubs today in some form or other,' opposition leader Sidney Holland told Parliament in 1948. 'More often than not we are not quite sure if it is legal or not... ${ }^{75}$ The extent of club drinking is shown by the fact that, once the floodgates on club licenses opened in 1977, licensed clubs soon outnumbered pubs by a factor of two to one. Boozy private parties also allegedly became commonplace in the face of restrictions. ${ }^{76}$

The liquor industry for its part responded to the restrictions through a number of innovations. To compensate for lack of outlets in many parts of the country, licensees and brewers resorted to using licensed and unlicensed agents to take liquor orders and make deliveries to customers. This practice was legal providing the actual seller of the alcohol was licensed and certain procedures were complied with. ${ }^{77}$ Bars were made bigger, and furniture removed so as to fit more people in. Pressurised beer hoses helped speed up service and flagon counters were located at the rear of bars to facilitate the purchase of cheap takeaway liquor before six o'clock. According to Freeland, a similar phenomenon emerged in Australia in the early closing era. ${ }^{78}$ As noted earlier, the trend for bigger bars had its logical outcome in the 1970s in the form of the booze barn, a venue that could accommodate hundreds of drinkers and supply them with ample parking space.

There were, therefore, a range of behavioural and commercial responses that emerged during the era of relatively severe availability restrictions. These insured that the overall level of consumption was little affected by the controls and it is therefore hardly surprising that drinking did not notably increase once controls were removed. However it is not just that drinking did not increase, but in the mid 1970s the rate of alcohol consumption

\footnotetext{
${ }^{74}$ Report RCL, pp. 236-7.

75 N7PD 1948, vol. 284, p. 4206.

76 Ausubd, The Fern and the Tiki, p. 52.

77 Report RCL, pp. 139-141 and LCC Annual Report, AJHR 1955, H-3, pp. 8-10.

${ }^{78}$ Freeland, Anstralian Pub, p. 176.
} 
stopped its long climb and in the 1980s began to fall. New Zealand appeared to be part of a trend evident across a range of developed countries. Between 1980 and 2001, per capita alcohol consumption fell by between 16 and 24 percent in the USA, Canada, Australia, New Zealand, Greece, Belgium, Spain, Austria and Switzerland and by lesser amounts in Sweden, Germany and the Netherlands. In France consumption fell by 29 percent and in Italy by 41 percent. $^{79}$ As has been seen from earlier discussions, economic factors often provide the most fruitful explanation for changes in consumption patterns. Increasing economic uncertainty from the mid 1970s may have inhibited liquor purchases in a variety of countries. Increased awareness of the dangers of drinking may also have played a part in reducing consumption, along with more vigorous enforcement of the drink-driving laws. In New Zealand alcohol became more expensive due to increased excise taxes. With the memories of 1958 gradually fading, governments regained courage and raised liquor taxes in every year but one (an election year) from 1976 to $1984{ }^{80}$ Changing consumer tastes also appear to have been a factor in the continuing reduction in drinking. Regular surveys by Statistics New Zealand indicate that the percentage of household expenditure on alcohol did not change significantly during the 1990 s despite falling consumption. ${ }^{81}$ This indicates that New Zealanders were paying more per unit of alcohol by purchasing more expensive and presumably better quality liquor. ${ }^{82}$ The sale of wine, and later beer, in supermarkets may have enhanced this trend by increasingly putting women in control of household alcohol purchases. ${ }^{83}$ The trend to consume better quality wine appears to have been international and may help explain the big falls in consumption in wine-drinking countries such as France and Italy.

Bucking the international trend of falling alcohol consumption between 1980 and 2001 were the United Kingdom (a 16 percent increase), Finland (a 17 percent increase), and the Republic of Ireland (a 47 percent increase). ${ }^{84}$ All three countries enjoyed relatively strong

\footnotetext{
79 All figures from World Drink Trends 2003, I lenley-on-Thames, 2002, p. 10.

${ }^{80}$. Ishton and Casswell, Aliobiol Pricing Poliy in New Zealand, pp. 8-9. Spreading the increases over time probably helped lessen their electoral impact.

81 Spending on alcohol was estimated at 2.6 percent of weekly household expenditure in 1988-9, NZOYB 1990, p. 168 , and 2.5 percent in 1998, Statistics New Kealand, "Houschold Expenditure 1998" accessed at www.stats,govt.nz, A figure of 2.6 percent was also report in the N7.OYB in 1993, p. 91 and 1997, p. 133.

82 See, for example, Beer Wine and Spirits Council of New Zealand, "Quality Rises as Volumes Flatten", Facts and Figures, The Council, 2001.

83 Industry sources claim that 70 percent of supermarket wine purchases are made by women, Dominion Post, 13 March 2004 , p. E.7.

${ }^{84}$ World Drink Trends 2003, p. 10.
} 
economic growth during most of the period, but it is notable that they also retained most of their traditional restrictions on liquor sales. England, Wales and Northern Ireland, for example, continued to impose uniform 11 pm public house closing until November 2005 when the restrictions were lifted under the provisions of the 2003 Licensing Act. ${ }^{85}$ Scotland and the Republic of Ireland continued to impose uniform opening hours in 2006. As with New Zealand in earlier times, such restrictions did not appear to have made the inhabitants more temperate drinkers.

\section{The Longevity of Restrictions}

So if liquor restrictions did not reduce drinking and had negative social effects, why were they retained for so long? Not only were restrictions retained but, as outlined in Chapter 1, they were generally stricter and longer-lasting than those adopted in neighbouring Australia. One important reason has already been outlined in Chapter 3, that the regular repetition of referendums on liquor had the effect of reinforcing entrenched attitudes and made politicians wary of provoking the temperance lobby by liberalising the drinking laws. It has also been argued that an ongoing confidence in the ability of availability restrictions to reduce drinking was a factor. To some extent this confidence persisted in the face of evidence the restrictions did little to reduce alcohol consumption. For example the government had budgeted for a fall in income from beer duty once six o'clock closing was introduced in December 1917. However the beer duty take actually increased by 50 percent between the 1917-18 financial year, most of which was in the ten o'clock closing period, and 1920-21 when six o'clock closing was in force. ${ }^{86}$ The government greatly underestimated revenue from the beer tax in its budgets of 1918 and 1919 because of an expectation, explicitly stated in 1918, that the amount collected would be affected by the reduction in legal hours of sale. By 1920 Ministers and officials had adjusted their beer duty estimates, having realised that six o'clock closing had been followed by increased rather than reduced demand for beer. Yet despite this evidence six o'clock closing remained in place for 50 years. The same occurred in relation to the reduction in licence

\footnotetext{
85 Jenny Booth, Sam Coates and Stewart T'endler, 'More than 1,000 places to serve alcohol 24 hours a day', 'l"imes Online, 23 November 2005, http:/www timesonline.co.uk/article/0,2-1886891,00.html, accessed 28 November 2005.

86 The discussion in this paragraph draws on information published annually in the AJHR, namcly the annual Financial Statement from the Minister of Finance (B-6) and the Ibstract of the Revenue and Fixpenses of the Public Accounts (B-1|Pt. 1]). The 1917-8 financial year ended on 31 March 1918 and therefore included four months of early closing. lax changes did not account for the greater tax take after six o'clock closing, as an increase in the rate of beer duty came into effect in April 1917 and it did not increase again until December 1921.
} 
numbers after 1894. By the early 1900s a rise in drinking and drunkenness was noted by contemporaries. ${ }^{87}$ However the debate focussed primarily on the issue of no-licence and therefore ignored the more significant one of freezing and reducing outlet numbers. The protagonists appeared to overlook that fact that most hotel closures came about because of the reduction option in the triennial ballot rather than through no-licence, and the freeze on new licences remained in place despite the evidence. Over time it came to be commonly believed that restrictions on alcohol led to less drinking, a belief encouraged by church and temperance groups. When the Minister of Justice introduced the Licensing Amendment Act in 1948 he was clearly under the impression that the restrictions introduced between 1893 and 1918 had led to a decline in drinking and drunkenness despite the fact that both had actually increased during most of that period. ${ }^{88}$

Bollinger rightly considered the support of the liquor industry for restrictions to be an important factor in their retention. As has been seen, the industry tended to support restrictions on new liquor outlets except in dry provincial areas, although this support faded in the 1980s and disappeared in the 1990s. But the industry officially if not enthusiastically advocated an end to six o'clock closing from 1945 onwards, a position that became less ambiguous in the 1960s. Other restrictions such as the continued ban on barmaids were opposed by the liquor industry. Clearly its support for availability and other restrictions was far from universal. Furthermore, in other countries the liquor industry often supported availability restrictions for reasons similar to those applying in New Zealand. Industry attitudes therefore fail to explain the particular persistence of restrictions in this country.

As noted in Chapter 1, New Zealand was in the main consistently slower than the Australian states in relinquishing controls on alcohol. Two explanations are proposed for this difference. One is that discussed in Chapter 3, that the regular repetition of liquor polls had a conservative effect. The other is a more general one relating to the relative isolation of New Zealand. From the 1880s to the 1950s New Zealand became increasingly insulated from overseas influences. With a relatively low level of net migration after the 1870 s and a rising birth rate from the mid 1940s, the proportion of New Zealand-born in the population rose almost continuously from the 1880 s to the

\footnotetext{
k7. McKeaguc, Probibition or No License in Nen Zealand, published in 1905.

88 NZPD 1948, pp. 4192-3.
} 
1990s. ${ }^{89}$ Few New Zealanders travelled, except to take part in war, until the 1960s. In 1939 over half the soldier recruits from Otago and Southland had reportedly never left their home province and 80 percent had never left the South Island." In 1950 just one percent of New Zealanders left the country on a short-term business trip or holiday. ${ }^{91}$ Overseas visitors were also rare, with the striking exception of the American 'invasion' during the Second World War. ${ }^{92}$ Until the 1950s annual visitor numbers were generally under $16,000 .^{93}$ Despite the jet travel revolution annual visitor numbers did not reach 200,000 until the 1970 s compared with over a million in the mid 1990s. ${ }^{94}$ Newspapers, radio broadcasts, newsreels and movies gave some contract with the outside world but television did not become widespread until the mid 1960s. ${ }^{95}$ New Zealanders were therefore only intermittently exposed to conditions and attitudes in other countries on any scale, particularly with the low level of travel, immigration and visitor arrivals from the mid 1920s to the late 1940s. New Zealanders lacked even the exposure to varied laws and institutions that interstate contact provided to Australians. The result appears to have been an increasingly insular outlook on the part of much of the populace. After a year in New Zealand in the 1950s, Ausubel adjudged insularity to be 'one of New Zealand's most formidable problems.". He blamed this, along with an allegedly high degree of social conformity, in part on 'the remoteness of the country, both physically and psychologically, from the rest of the world and its relatively small population, ${ }^{97}$

An example of this increasing insularity of outlook can be seen in the changing attitudes towards liquor restrictions. The idealism of the heyday of prohibitionist campaigning gradually disappeared. Early prohibition advocates had commonly put forward the progressive argument that the law could be used to reform society, often claiming that if liquor sales were outlawed then people would gradually come to accept that drinking was

\footnotetext{
89) NZOYB 1990, p. 144 and NZOYB 1998, p. 93.

${ }^{90}$ Belich, Paradise Reforged, p. 350.

91 Statistics New Kealand, 'Propensity to Travel of New 'Zealand Residents: Overseas Trips by New 'Zcalanders' in 'Tourism and Migration 2000', December 2001, available at http://www.stats.govt.nz/analytical-reports/tourismmigration-2000/default htm, accessed 20 October 2005.

92 Belich, Paradise Reforged, pp. 289-292.

${ }^{93}$ McClure, The Wonder Comtry, pp. 180, 210-2.

94 N\%OYB 1998, p. 296.

${ }^{25}$ N/OYB 1990, p. 340. There were only 4600 television licenses in 1961.

${ }^{6}$ Ausubel, Fern and the Tiki, p. 26.

97 Ausubel, p. 122.
} 
morally wrong. ${ }^{98}$ Rather than merely reflecting societal norms, the law would be a tool that changed attitudes and enabled society to reap the social and economic benefits of reduced alcohol consumption. But over time the existing restrictions came increasingly to be seen as a way of protecting the New Zealand way of life and ensuring social conformity. This 1945 statement from the Alliance illustrates the point:

The New Zealand Alliance deprecates most strongly any suggestion of drinking on the Continental system, as it is called, particularly the notion of family drinking - that is, that a man can take his wife and children into restaurants and other places for the consumption of liquor. It is not in accordance with New Zealand practice and with our habits, and for the past 30 or 40 years or even more the notion of family drinking has been something foreign to the ideas of the generality of our population. ${ }^{99}$

Thus the law was no longer seen by prohibitionists as an instrument of progressive social reform. Rather it was there to protect citizens from pernicious foreign influences and fix in perpetuity the social customs of the early twentieth century.

The perception that liquor restrictions helped underwrite the New Zealand way of life can be seen in changing attitudes towards the purpose of six o'clock closing. While the temperance aim of reduced drinking was largely considered as given, the influence of the ideal of romantic domesticity meant that early closing increasingly came to be seen as protecting family life. While this had always been an aim of temperance campaigners, it is notable how the domestic ideal came to predominate in popular thinking by the mid twentieth century. When the debate on licensing hours resurfaced in the 1940s and 1950s, even many supporters of evening drinking advocated a compulsory evening closing period. ${ }^{110}$ In the words of a member of the Westland Licensing Committee in 1955, 'there should be a break to enable men to go home for their meals'. Another member was wary of any extension of hours, which would 'entice men from their homes at night and spoil home life, leaving wife at home by herself. ${ }^{101}$ The 1960 licensing select committee considered that a dinner break would be necessary under early closing 'to induce menfolk

\footnotetext{
${ }^{98} \mathrm{Sec}$, for example, Adams, Professor Salmond's Blunder.

19) PRCL, p. 1960.

100 The submissions to the Royal Commission on Licensing on this issue were discussed in Chapter 5.

101 Minutes of the Westland Iicensing Committee for 9 November 1955 in I icensing Control Commission file, 'Suggested Changes in Licensing II fours', Archives New Zealand AADM, 567, 13e, 4/1/26.
} 
to go straight home for an early dinner in the family circle,. ${ }^{102}$ To some extent early closing had become a protector of national traditions and a national tradition in its own right. '[L]et us enhance our already good New Zealand way of life by sticking to the proven value of six o'clock closing,' a former police officer wrote to the LCC in 1963. '[W] should not try to copy overseas liquor laws but aim at a sound standard distinctly our own'. ${ }^{103}$ An Australian innovation intended as a temporary measure was thus perceived by some as an intrinsic part of New Zealand culture. The insularity of this view contrasts with that held by many who had lived or travelled abroad. The Grey River Argus editorialised in 1955 that 'New Zealanders who have visited overseas countries will realise that lengthy trading hours make for better drinking and less drunkenness. ${ }^{104}$ As was seen from evidence presented to the Royal Commission on Licensing, support for more liberal liquor laws came almost entirely from those citing overseas experience. Similar exposure to foreign influences appeared notably less common among those supporting the status quo. The police officer quoted above gave many details of his life since joining the police force in 1908, none of which included overseas travel. The dangers of evening drinking came to be seen as more than just increased alcohol consumption. It threatened a way of life.

The restrictions that prevented the establishment of new drinking facilities also came to be seen in terms of lifestyle protection. The temperance ideals that led to a virtual freeze on new licenses in the late nineteenth century were no longer apparent in later legislation such as the 1948 act that introduced local objection polls. This latter measure explicitly aimed to protect the tranquillity and property values of those in the growing suburbs, as shown by the fact that one of the main grounds on which objectors could force a poll was that the neighbourhood of a proposed new pub was predominantly residential. ${ }^{105}$ This contrasts with the official policy in England of encouraging the establishment of public houses in the growing suburbs. ${ }^{106}$ As government control of the economy became increasingly interventionist after 1935, liquor regulation became more explicitly aimed at protecting existing publicans from competition, a clear objective of the 1962 Sale of

\footnotetext{
102 Committee on Licensing 1960, p. 28. As was seen in Chapter 6, the need for a dinner break was a common view among those making submissions to the Royal Commission on Licensing.

103 Letter from William Calwell in Licensing Control Commission file, 'Suggested Changes in Licensing Hours', Archives New $/$ ealand . I.IDM, 567, 13e, 4/1/26.

10.+ Grey River Argus, 14 November 1955.

105 Licensing Amendment Act, New Zealand Statutes 1948, p. 949.

106 I Iaydon, The English Pub, pp. 267, 287.
} 
Liquor Act. ${ }^{117}$ Again, the purpose of liquor restrictions was being bent to reinforce prevailing ideologies. The restrictions on drink had to some extent become as much of a national tradition as the regular liquor polls that helped keep the restrictions in place.

The belief that liquor restrictions reflected and preserved a unique New Zealand culture was occasionally seen in official circles. It should be clear from earlier chapters that New Zealand liquor legislation was generally a result of lobbying and compromise. In 1888 King's Counsel C.B. Morison wrote of the 1881 Licensing Act that he was 'inclined to think that the New Zealand statute consisted originally of clippings of liquor laws of every part of the British Dominions'. ${ }^{108}$ Yet decades later Justice Minister Rex Mason expressed the contrary view, claiming that New Zealanders' drinking habits had not conformed 'to some merely accidental or arbitrary legislation'. Mason had travelled abroad for the first time in 1946, and spoke of people sitting at Parisian pavement cafes 'sipping from glasses and watching the crowds go by, quite pleasantly'. But he added that, because of custom and climate, such scenes could never be repeated here, regardless of the drinking laws. ${ }^{109}$ The laws were thus seen as conforming to rather than determining the drinking culture. The 1960 parliamentary select committee on licensing put this view more explicitly:
In considering what changes might be made, we sometimes have pointed out to us the experiences of other countries. This may be instructive, but it has to be remembered that the law in our country may be the result of, and adapted to, the habits of the people here, and that merely to reproduce their laws here would not necessarily solve a problem or suit our habits. The social habits of each country are not readily changed by changes in law, and we have always to consider the habits and points of view of our own people when thinking of changes in the law. ${ }^{110}$

This mode of thinking was exemplified in 1967 when a Dunedin Presbyterian Minister urged people to reject legalised evening drinking because 'our national drinking habits are very much more bound up with our national character than with the time our hotel doors close'. ${ }^{11}$ A newspaper correspondent similarly argued that 10 o'clock closing may have proved better in overseas countries but 'Kiwi drinkers are not prepared for such a big step

\footnotetext{
${ }^{107}$ Sale of Liquor Act, Nem Zealand Statues 1962, pp. 1142-4.

108 C.B. Morison quoted in PRCI, p. 441.

${ }^{109}$ NZPD 1947 volume 278, p. 714.

110 Committec on Licensing 1960, AJHR 1960, I .17, p. 9.

111 Otago Daily Times, 18 June 1967, p.1.
} 
yet. They are not ready to change their drinking habits. In the future ten o'clock closing may benefit New Zealanders. As yet, they are not educated to drinking sensibly." ${ }^{112}$ Six o'clock closing was thus seen by some as a symptom rather than a cause of poor drinking habits such as excessively rapid consumption, and the precipitous adoption of radical foreign customs such as evening drinking was something to be avoided.

It is being argued here that the lack of exposure to new ideas in an isolated New Zealand society caused many to see existing restrictions as the norm. Certainly there were changes in attitudes over time - the country was far from totally isolated. Mander's comments aside, the country had clearly changed considerably between 1912 and 1933 . The spread of the cinema and the motor car were just two of many dramatic innovations that had significant social effects. But, as was seen in the case of alcohol, this meant that to some degree the justification for restrictions came to be re-couched in terms of the new attitudes and the restrictions remained. New Zealand's adoption of secular sabbatarianism provides another illustration of the evolving rationalisation of restrictions. In the nineteenth century many in the evangelical churches successfully advocated government suppression of pleasurable activities on Sundays, which was considered to be a day for worship and reflection. As John Wigley has noted, Victorian sabbatarianism was motivated more by a desire to proscribe Sunday amusement than to ensure a break from work each week. ${ }^{113}$ However the sabbatarian doctrine was widely disputed in England and Australia, and Jackson adjudged that Australian sabbatarians were very much on the defensive by the early twentieth century, with libraries and museums opening and public transport commonly running on Sundays. ${ }^{114}$ In New Zealand, however, the Sabbath appeared to be strictly observed. When Andre Siegfried visited the country in 1904 he found all manner of Sunday activities suppressed by social convention and government action. Sunday excursion trains had been halted after pressure from the clergy, and work on Sunday was frowned upon:

From the early moming there is a deathlike stillness; trams hardly stir; trains do not stir at all. Of course, theatres and shops are closed; the football ground and the cricket field are

\footnotetext{
112 Otago Daily Times, 20 September 1967, p. 4.

113 Wigley, The Vitorian Sunday, p. 169.

${ }^{11+}$ Jackson, Chrreches and People, pp. 106-115.
} 
undisturbed. If some athletic association were to select this day for its games or meetings, public opinion would not for an instant tolerate such a scandal. ${ }^{115}$

Over the years sports were commonly at the centre of controversies over Sabbath breaking. Sunday golf was prohibited in Invercargill until 1932, when it was allowed until $1 \mathrm{pm} .{ }^{116}$ Sunday games in the Canterbury township of Oxford were looked upon with horror' in the 1930s. 'The few residents who play a game of golf on the tiny six-hole course are looked upon as being almost beyond the pale of civilisation. ${ }^{317}$ The local domain board banned Sunday afternoon tennis despite an assurance that games would not coincide with church services. ${ }^{118}$ The Auckland City Council continued to ban all organised Sunday sports well into the $1950 \mathrm{~s} .{ }^{119}$ The occasional compromise or victory for sports enthusiasts was rare. A motion banning the Invercargill tennis club from Sunday play was narrowly defeated at a 1922 city council meeting. ${ }^{120}$ In 1935 the authorities agreed that bored Mount Albert Grammar boarders could play Sunday games as long as these were not organised team sports, were undertaken 'discretely' and did not clash with 'the hours of divine service'. This concession was considered significant enough to be reported in a Wellington newspaper. ${ }^{121}$ In 1955 the Auckland City Council gave special dispensation for a representative soccer trial match to be held on Sunday providing no spectators were admitted to the ground. ${ }^{122}$

Of course not just sports were affected. Sunday cinema screenings were banned in Auckland until 1953. ${ }^{123}$ In 1951 the monthly magazine Here and Now published a feature comparing the minimal Sunday activities available with those in a variety of international locations including Paris and London. ${ }^{124}$ Poet A.R.D. Fairburn acerbically described Sunday, on which even the dubious comforts of the cinema were prohibited, as "the most

\footnotetext{
115 . Andre Siegfried translated by E.V. Burns, Democracy in New Zealand, London, 1914, pp. 321-2.

116 Millison, 'The 38 Year Drought', pp. 50-1.

117 H.C.D. Somerset, Littledene: A New Zealand Rural Community, Wellington, 1938, p. 34.

118 Somersct, Littledene, pp. 34-5.

119. Auckland Star, 27 May 1955, p. 29.

${ }^{120}$ Millison, 'The 38 Year Drought', p. 50.

121 The Dominion, 26 September 1935.

122 Amikland Star, 27 May 1955, p. 29.

${ }^{123}$ Sonya Haggic, Never on Sunday', New Zealand Women's Weekby, 4 July 1988, p. 21.

124 Here and Now, A pril 1951, pp. 21-26.
} 
depressing day of the week'. ${ }^{125}$ The restrictions continued in later decades, generally with the support of the majority of the population. In a 1968 poll just 24 per cent of respondents favoured allowing bars to trade on Sundays. ${ }^{126}$ Sunday newspapers were illegal until 1965 and Sunday television advertisements were banned until the $1990 \mathrm{~s} .{ }^{127}$ In 1988 the Nem Zealand Women's Weekly discussed the continuance of Sunday bans on activities such as shopping, horse racing and drinking in bars. ${ }^{128}$ A National Research Bureau poll found that a majority of respondents favoured retention of these bans. ${ }^{129}$

Yet even in 1904, Siegfried noticed something distinctive about these restrictions. The New Zealander, it seemed, regarded Sunday observance as 'a social and national tradition even more than a religious one. ${ }^{136}$ As a result Sunday restrictions were increasingly rationalised in secular rather than religious terms. The Auckland City Council justified its sports ban as enforcing the tradition of Sunday peace and quiet rather than as avoiding upsetting the pious. ${ }^{131}$ In later times the justification for trading restrictions on Sundays and religious holidays was often couched in terms of the rights of shop workers. ${ }^{132}$ A poll in 1988 found that a majority were opposed to legalised Sunday shopping, largely 'because it detracted from the perceived need for a day of rest and relaxation'. ${ }^{133}$ Another poll in 1999 found that a significant minority of respondents opposed Sunday liquor sales, but only three per cent of these cited religious reasons for doing so. ${ }^{134}$ Even lobbyists with religious motivations for banning Sunday activities realised such arguments would have little public appeal and therefore invoked more secular concepts such as 'family values' in their public pronouncements. ${ }^{135}$

\footnotetext{
125 A.R.D. Fairburn, 'Thoughts on a dry Sunday afternoon', Here and Now, April 1951, p. 21. In fact Fairburn was decidedly negative about the limited range of activities available on any day of the week.

126 Cited by M.D. Jurgeleit, 'T'iguratively Speaking' in New Zealand Iiquor Industry Council, Papers Presented at the News Media Forum of the New Zealand Liquor Industry Comail, Wellington, 1973, p. 26.

${ }^{127}$ M.I I. [ Iolcroft, 'The Press in a Visual Age', in New Zealand's Heritage: the Making of a Nation, Sydney, 1971, p. 2790.

128 Haggie, Never on Sunday', pp. 20-22.

129 National Rescarch Burcau poll for the Save Our Sundays campaign, cited by the Advisory Committec on the Shop Trading I Iours Act 1977, The Shop Trading Hours Act 1977, Wellington, 1988, Appendix 8.

130 Siegfried, Democray in Nen Zealand, p. 322.

131 Amkiand Star, 27 May 1955, p. 29.

132 Scc, for example, Dominion Post, 13 April 2004, p. A4. Arguments for the protection of shop workers failed to address the issue as to why similar protection was not needed for workers in factories, offices and on building sites.

${ }^{133}$ Heylen Poll cited by the Advisory Committee on the Shop Trading Hours Aet 1977, Appendix 8.

$13+$ 'Rcligion takes back scat to liquor salcs', The Dominion, 3 May 1999.

${ }_{135}$ Rosemary Vincent, 'Defender of the Sabbath', New Zealand Women's Weekly, 4 July 1988, p. 22.
} 
Both restrictions on alcohol and on Sunday activities were widely perceived as helping preserve a supposedly distinctive New Zealand way of life. The congruence between the two types of restriction was exemplified by the fact that the general secretary of the Alliance founded the Save Our Sundays organisation in 1988 to lobby for continued Sunday restrictions. ${ }^{136}$ The notion that legal restrictions should be used to fossilize a particular way of life came about because demographic change and geographical isolation gradually reduced the exposure of New Zealanders to foreign ideas and customs. This lack of exposure to alternatives helped embed restrictive social customs in New Zealand society even though the beliefs and attitudes that lay behind them were not always widely shared. Once sanctioned by law, the restrictions came either to be seen as social norms or were justified in new ways in line with the changing times. In relation to alcohol these social norms were reinforced by national and local polls that gave politicians a regular reminder of the strength of the prohibition lobby. The tight society, in this respect at least, remained tight until exposure to foreign influences provided a catalyst for change.

Just as it has been argued that demographic factors and geographical isolation helped perpetuate the restrictions imposed during the era of the 'crusade for moral harmony', demographic change and reduced isolation helped wind back these restrictions. Immigration revived after a long hiatus and the country gained some 200,000 people through migration between 1951 and 1966. ${ }^{137}$ Transport improvements brought an ever increasing number of tourists to the country, with particularly large percentage increases in the early 1960s and early 1970s. As international transport became cheaper and faster, more New Zealanders travelled abroad. Short-term departures increased by ten percent per annum in the $1960 \mathrm{~s}$ and 14 percent per annum in the $1970 \mathrm{~s} .{ }^{138}$ Long-term departures also increased, especially in the 1970 s, with many returning with what was commonly termed 'overseas experience'. ${ }^{139}$ Limited television broadcasts began in the late 1950s and by 1966 some 70 percent of households owned a television set. ${ }^{140}$ New Zealanders were increasingly brought into regular contact with the outside world, resulting in a widespread questioning of attitudes and restrictions.

\footnotetext{
136 Vincent, Defender of the Sabbath'. The individual in question is Tom Quayle who led the Alliance during most of its last decade of existence. 
Demographic change also played a significant role in the changed attitudes. The generation whose formative years were in the heyday of the prohibition movement were dying off at an increasing rate. Between 1911 and 1928 nearly half of all voters had supported prohibition. ${ }^{141}$ By 1960 some surviving members of this cohort were still in their early 50 s but many were considerably older. ${ }^{142}$ Those raised in an era of temperance songs and widespread anti-drink propaganda were rapidly disappearing, and few of those born in later decades had been subject to the same influences. It is also doubtful that the numerous immigrants who arrived in the 1950 s and early 1960 s, mainly from Britain, were strongly inclined towards banning the sale of alcohol. Support for prohibition in the triennial polls plummeted in the 1960s as a result, reaching a low of 13 percent in 1969 . By then even the most youthful of the surviving prohibition voters from the 1920 s would have been in their sixties. ${ }^{143}$

A survey of 1500 voters carried out after the 1963 general election provided evidence of a significant age-related divide on liquor issues. ${ }^{144}$ The survey found that half of female respondents aged over 65 had voted for prohibition in the 1963 licensing poll, compared with fewer than one in six women aged under 30. While less than one in nine male respondents had voted prohibition in 1963, more than one in four males aged over 65 had done so. ${ }^{145}$ The survey provided little evidence on previous voting behaviour but it could be speculated that many older prohibition voters would have first voted that way in the 1920 s or earlier and had continued to do so ever since. ${ }^{146}$ Not surprisingly these older voters - and not just prohibition supporters - showed a marked degree of conservatism on other liquor-related issues. The survey found that only 39 percent of respondents aged over 60 agreed that 'provided drinking conditions are improved, drinking hours in New Zealand hotels should be extended'. In contrast over 70 percent of those aged under 40 agreed with extended hours. ${ }^{147}$ It is perhaps significant that most of this latter group would have been too young to have voted in the 1949 referendum on drinking hours. ${ }^{148}$

\footnotetext{
${ }^{1+1}$ Forty-cight percent of all those who voted in the seven prohibition polls between 1911 and 1928 voted prohibition.

1+2 For cxample a 40 year old prohibition voter in 1925 would have been 75 years old by 1960 . As this cohort of voters aged, their mortality rate also increased.

$143 \mathrm{~A}$ voter who was 21 in 1928 would have been 62 in 1969

144 Ashenden et al, 'Attitudes towards liquor among New '/caland voters'.

1+5. Ashenden et al, pp. 11-14.

146. All those aged over 65 in 1963 would have been old enough to have voted in the December 1919 licensing poll.

147 Ashenden et al, 'Attitudes toward liquor among New '/ealand voters', pp. 11-15.

148 Those who voted in the referendum in March 1949 would have been aged at least 35 by the end of 1963.
} 
The over- 60 s were twice as likely as the rest of the sample to be 'strongly opposed' to extended hours. ${ }^{149}$

It therefore appears that the generation at the centre of the 'great tightening' was the one whose attitudes had been most set in stone by New Zealand's isolation. Later generations, including new immigrants, had not been subject to the same influences and by the 1960 s were exposed to an increasing array of alternatives. As a result they appeared much more open to change. The presence of the 'prohibitionist' generation in positions of authority and their ability to influence social norms through the power of the ballot box was reducing as their numbers declined. Changing social attitudes were reflected in such things as an increasing rate of ex-nuptial births after the Second World War and the rising rate of per capita alcohol consumption noted in earlier chapters. ${ }^{150}$ The influence of the ideology of domesticity was also on the wane. In the 1940s and 1950s many were prepared to accept evening drinking so long as provision was made for a dinner break. By 1967 a public opinion survey showed that a clear majority were prepared to accept later closing without an enforced meal break. ${ }^{151}$ New Zealanders, it seemed, had come to believe they had acquired sufficient willpower to resist temptation and go home for dinner without legal compulsion.

\section{Conclusion}

It has been argued in this chapter that the restrictions imposed on liquor availability in New Zealand had a variety of negative social effects. In relation to dry districts these included illegal liquor sales, the bulk purchase and consumption of liquor, and resentment on the part of a significant minority at the barriers placed on access to alcohol. Restrictions elsewhere often resulted in overcrowded and unhygienic bars and the rapid consumption of the 'six o'clock swill'. Basic facilities such as food, entertainments and even chairs and tables became a rarity. Women were repelled by the unpleasant surroundings, thus contributing to gender segregation. Early closing, restricted bar numbers and the banning of licensed restaurants reduced the options for social interaction and made a poor impression on foreign visitors. In later decades continued restrictions resulted in the building of 'booze barns'.

\footnotetext{
149. Ashenden et al, 'Attitudes toward liquor among New 'Kealand voters', pp. 11-12.

150 NZOYB 1998, p. 95.

151 Evening Post, 13 June 1967, p. 8, and NZPD 1967, volume 351, p. 1375.
} 
Restrictions on outlet numbers and hours of sale did not have the expected effect of reducing liquor consumption because people and businesses changed their behaviour to fit in with or circumvent them. People purchased liquor in bulk to consume in private homes or on the street. Agents were used to take liquor orders and make deliveries to customers. The pace of drinking in bars sped up and often took place illegally after hours. Many joined sports and other clubs where people could use the loophole of the locker system' to drink together in the evenings. Clubs sold liquor illegally knowing that the rather hazy laws they operated under were rarely enforced. The industry streamlined its operations by renovating bars for efficiency rather than comfort and introducing technology that sped up the process of dispensing beer for onsite drinking and to take away after closing time.

The legislative controls that resulted in these various behavioural changes were maintained throughout much of the twentieth century for a complex array of reasons. Politicians were wary of advocating reform, as liquor issues threatened party unity, and repeated liquor polls provided a regular reminder of the strength of the temperance movement. Restrictions protected vested interests within the liquor industry from competition. Few others lobbied for reform because it was commonly believed that restrictions worked in the interests of temperance and the majority lacked exposure to alternatives. The country became increasingly isolated from external social influences in the early decades of the century. It was only when this isolation started to abate in the post-war period that significant change finally came. Furthermore the generation born in the late nineteenth and early twentieth century and raised in an environment of intense anti-alcohol propaganda were dying off at an increasing rate by the $1960 \mathrm{~s}$. Later generations raised in an era when prohibition was a spent force did not always share the same values, although they often found new reasons for supporting the status quo. But gradually exotic influences made their mark and the tight restrictions that had been relatively undisturbed for four or more decades were eased after 1960. The process of change accelerated in subsequent decades and by the twenty first century few restrictions remained. 


\section{CONCLUSION}

The central aim of this thesis has been to assess whether the historical evidence from New Zealand supports the availability theory of alcohol. The theory proposes that the consumption of alcohol can be reduced by restricting its availability, thereby reducing alcohol-related problems. The availability theory was propounded in detail by the international alcohol research community from the 1970 s but was also implicit in 'restrictionist' approaches increasingly adopted in a variety of countries in the nineteenth and early twentieth centuries. Liquor restrictions imposed in New Zealand between 1894 and 1918 included the banning of new bars, raising the drinking age and six o'clock closing. The result was a rapid decrease in the availability of alcohol which should in theory have resulted in less drinking. The restrictions were eventually removed almost as rapidly, particularly after 1967, as the influence of restrictionist thinking faded despite lobbying by alcohol researchers who advocated stronger controls on the availability of alcohol.

The rapid imposition of liquor controls and their equally rapid removal makes New Zealand an ideal test case for the effectiveness of restrictionist approaches to liquor control. Asquith's characterisation of New Zealand as a social laboratory 'for the information and instruction of the older countries of the world' is entirely appropriate in this regard. ${ }^{152}$ The question is not purely historical. In recent years disagreement regarding the merits of restricting access to alcohol emerged in several countries in several contexts. In New South Wales there was controversy in 2003 and 2004 over proposals to reduce barriers to new liquor outlets, with claims that this would lead to a 'proliferation of outlets', ${ }^{153}$ In New Zealand there has been ongoing controversy following the lowering of the drinking age to 18 in 1999, resulting in Parliament forwarding a private member's bill reversing this change to a select committee for consideration. ${ }^{154}$ Debate in England

\footnotetext{
152 Quoted in Sinclair, A History of New Zealand, p. 195.

${ }^{153}$ Geesche Jacobsen, 'T et more outlets sell liquor, Carr told'.

$15+$ Dominion Post, 16 March 2006, p. 12. The Sale of I iquor (Youth Harm Reduction) Amendment Bill was forwarded to Parliament's Law and Order Committee in 2005 but hearings were delayed by the general election that year.
} 
centred on 2003 legislation that removed all standard restrictions on pub opening hours from November 2005, allowing hours to vary between outlets at the discretion of local licensing authorities. In all these cases lobby groups claimed that the changes would lead to increased alcohol consumption, or in the New Zealand case that a lower drinking age had already resulted in more teenage binge drinking.

Another controversy also arose in Britain, where two major reports were published in 2004 on the costs that alcohol imposed on society. The Academy of Medical Sciences advocated measures that included tax increases and lower duty-free allowances to decrease liquor consumption. ${ }^{155}$ Their report outlined an array of evidence to show that 'per capita consumption stands out as a crucial determinant of alcohol-related harm'. ${ }^{156}$ In contrast a report from the Prime Minister's Strategy Unit proposed targeting the misuse of alcohol rather than attempting to reduce the consumption of the entire population. ${ }^{157}$ This latter report was criticised for dealing with the symptoms rather than the causes of alcohol abuse. $^{158}$

The historical evidence from New Zealand presented in this thesis can throw light on these debates. It cannot help answer the question as to the desirability of trying to reduce average liquor consumption, although sources such as the Academy report provide strong indicative evidence that this may be a worthwhile objective. However New Zealand's historical record of implementing rapid changes in liquor availability provides valuable evidence as to which measures are likely to be the most effective in reducing alcohol consumption.

Ironically the only restriction that appeared to have a significant and unequivocal effect on alcohol consumption was the one that was the least clearly directed at achieving this end the increasing of taxes on alcohol. Arnold Nordmeyer's doubling of beer and spirits duties in 1958 had the fiscal and economic objectives of dealing with a balance of payments crisis and ensuring the government could meet its election promises. ${ }^{150)} \mathrm{A}$ significant decline in the consumption of beer and spirits would conflict with these aims.

\footnotetext{
155 The Academy of Medical Sciences, Calling Time, p. 9.

156 The Academy, p. 22, italics in original.

${ }^{157}$ Prime Minister's Strategy Unit, Alcobol Ham Reduction Strategy for England, London, 2004.

${ }^{158}$ See, for example, Michael Marmot, "The Rising lide of Alcohol', Addiction, September 2004, vol. 99. no. 9, p. 1090.

159 Sinclair, History of New Zealand, p. 303 and Robert Chapman, 'Trom Iabour to National', in W. H. Oliver with B. R. Williams eds, The Oxford History of New Zealand, Wellington, 1981, p. 364.
} 
All the same the result was an immediate and sustained fall in alcohol consumption, as had also happened after similar tax increases in 1921. These results provide strong support for the British Academy's recommendations for tax increases and reduced dutyfree allowances. It should be noted, however, that the outcomes may be unique to a geographically isolated country like New Zealand where the lengthy journey by ship or airplane provides a practical barrier to large-scale private liquor imports.

The New Zealand evidence also indicates that the statutory minimum age for the purchase of alcohol may have an effect on total alcohol consumption. The lowering of the drinking age to 20 in 1969 was followed by a sharp upswing in liquor consumption, as also happened when the age was further lowered to 18 in 1999. Increased drinking after 1999 was driven largely by increased consumption of the pre-mixed spirits-based drinks ('alcopops') that are reputedly popular with teenagers. ${ }^{16)}$ The evidence therefore indicates that the previous age restriction of 20 was being enforced in many cases, despite the numerous exceptions to the law, and was thus discouraging some teenagers from drinking. Whether these consumption increases will be sustained remains an open question. The rise in liquor consumption after 1969 came to a halt within five years, perhaps because of a slowdown in economic growth.

The New Zealand experience provides lessons for the English debate over pub closing hours in two respects. Firstly, even a severe restriction on hours in the form of six o'clock closing had no apparent impact on the total consumption of alcohol. Secondly, the changes to standard opening hours introduced in New Zealand under the Sale of Liquor Act 1989 were very similar to those introduced in England under the 2003 Licensing Act. Prior to 1990 bars in New Zealand were generally required to close at either ten or $11 \mathrm{pm}$ depending on the day of the week and conditions of their licence. ${ }^{161}$ From 1990 the hours of sale were determined by local licensing authorities and could vary between premises, with closing times of three am or later being common. This change was followed by a near-continuous decline in per capita alcohol consumption for the rest of the decade. There is therefore no reason to suppose that similar changes in England, Wales and Northern Ireland will lead to increased liquor consumption.

\footnotetext{
160 As outlined in Chapter 6, alcopop consumption doubled between 1999 and 2005.

161 Ilowever there were exceptions relating to restaurants and night clubs.
} 
Restricting the number of liquor outlets proved to be the least effective measure in limiting alcohol consumption in New Zealand. In fact the relationship was the opposite of what might be expected. The halving of per capita pub numbers between 1894 and 1910 was accompanied by a 33 percent increase in per capita beer consumption, a 21 percent increase in spirits consumption, an eight percent increase in wine consumption and a 77 percent increase in the rate of drunkenness convictions. On the other hand a 320 percent increase in the number of licensed liquor outlets per capita in the 20 years from 1977 to 1997 was accompanied by a 24 percent fall in the consumption of pure alcohol per person aged over 15. The dire predictions made in New South Wales about the detrimental effect of a 'proliferation of outlets' are therefore unlikely to be realised.

This thesis also addressed the question as to why liquor restrictions were retained for so long before their rapid removal. Six o'clock closing lasted for 50 years. The freeze on public house numbers instituted in 1894 remained substantially in place for almost 70 years. Clearly neither of these restrictions was retained because they demonstrably reduced alcohol consumption. Their longevity was largely a result of the inertia of the political process. The advent of party politics in the 1890 s coincided with a period when liquor issues were very much to the fore and were potentially destructive to party unity. A strategy was therefore adopted of trying to put liquor issues to the vote of 'the people' whenever possible in the form of local and national referendums, and political parties thereafter generally eschewed taking a specific stand on liquor issues. The regular submission of liquor issues to referendums further exacerbated the reluctance of politicians to act. The General Licensing Poll instituted in 1911 provided for triennial binding referendums on prohibition. The prohibition option was supported by at least 250,000 voters in all but six of the 24 referendums held over 76 years, providing politicians with a regular reminder of the strength of the temperance lobby. The licensing poll provided no options for those wanting less restrictive liquor laws. No politician wants to upset over a quarter of a million voters when there is little evidence that anyone is clamouring for change. The survival of the General Licensing Poll until 1989 is in itself an example of the reluctance of politicians to offend the temperance lobby.

The reluctance of politicians to act was reinforced by the absence of lobby groups advocating the removal of restrictions. The liquor industry was influential but its constituent interest groups, including brewers, publicans and wholesalers, were often divided in their aims. Many in the industry supported continued restrictions on access to 
alcohol. Controls on outlet numbers protected existing providers from competition, as did the legal requirement for publicans to provide accommodation for travellers, which raised the costs of entry to the industry. Many publicans supported six o'clock closing, which allowed them to make a comfortable living without the inconvenience of evening opening. Even the perpetuation of suburban dry districts worked to protect those in the industry from competition.

The development of a reform lobby was further inhibited by the widespread belief that controls on access to alcohol reduced its consumption, despite the evidence to the contrary. Restrictions were also commonly seen as protecting aspects of the New Zealand lifestyle. Six o'clock closing was perceived as necessary to ensure men went home for dinner at a respectable hour for the good of family life. Restrictions on new outlets protected the quietude of the suburbs from the disruptive influence of the pub. The continued ban on licensed restaurants helped ensure young people and women did not acquire the drinking habit. These attitudes and beliefs were reinforced by a lack of exposure to alternatives. Immigrants were relatively few in number from the onset of the First World War until the 1950s. Until the 1960s overseas travel by New Zealanders was largely confined to taking part in warfare. Overseas visitors were rare. The movies, newspapers and magazines provided a regular exposure to the outside world but were an imperfect substitute for the real thing.

Strict controls on outlet numbers and hours of sale failed to reduce liquor consumption in New Zealand for the simple reason that people and businesses changed their behaviour to fit in with or circumvent the restrictions. Outlet restrictions meant people often purchased liquor in bulk and occasionally through illegal channels. Sports and other clubs became illegal and semi-legal drinking venues, aided by vagueness in the law. Six o'clock closing resulted in people drinking more quickly in the limited time available, buying takeaway liquor and drinking illegally after hours. Publicans expanded their bars to fit more patrons and dispensed with luxuries such as chairs and tables. New technology allowed beer to be served with great rapidity. The social effects of these changes meant that even some immigrants were cautious of advocating reform. A witness to the 1945 Royal Commission on Licensing who had lived in New Zealand for 11 years recounted fond memories of English pubs but supported six o'clock closing. He was appalled by 
New Zealander's drinking habits and felt his adopted countrymen would not be ready for licensing reform until they had learned to drink in a civilised manner. ${ }^{162}$

Despite their seeming acquiescence in the face of restrictions, New Zealanders clearly relished their removal. When six o'clock closing ended people quickly took to legal evening drinking. Women began to frequent pubs after being virtually banished for 50 years by social disapproval and the unpleasant conditions. ${ }^{163}$ There was a seven-fold increase in the number of licensed clubs after 1948 and again after 1976 once the government loosened restrictions. From 1977 restaurant licences were made easier to obtain and BYO licences were allowed. By 1987 these reforms had resulted in a ten-fold increase in the number of restaurants at which people could drink alcohol with their meals. When the government finally opened the liquor market to any provider who met the required standards, as it increasingly did after 1990, the number of licensed liquor outlets doubled within a decade.

Reforms from 1967 onwards provided increasing opportunities for socialising outside the home in response to consumer demand. These reforms culminated in the 1989 Sale of Liquor Act which threw out most of the principles that underlay New Zealand's licensing laws for over a century, including rationing of licences, restricted hours of sale, regular liquor referendums and an obligation for publicans to provide accommodation for travellers. Yet by 1995 the consumption of absolute alcohol per person over 15 was no greater than it had been in 1955, 40 years earlier. In 1955 the country had less than a quarter the number of liquor outlets per capita, licensed restaurants were forbidden and liquor sales were illegal in significant parts of suburban Wellington and Auckland. Pubs closed at six pm and with some exceptions barmaids and entertainments were banned. There is no evidence that any of these restrictions had any effect on how much people drank. It is doubtful that many New Zealanders would genuinely wish to return to the days of restrictionism.

\footnotetext{
162 PRCL, Pp. 1379-89.

163 Biggs, 'Political and Social Implications of Later Closing', p. 370 and Jurgeleit, 'Figuratively Speaking', pp. 18-19.
} 


\section{BIBLIOGRAPHY}

\section{Primary Sources}

\section{Official Sources - Published}

Abstract of the Revenue and Expenses of the Public Accounts, AJHR 1918-1923, B-1.

Accommodation/Liquor Link Inquiry Committee, Report, Wellington, 1979.

Annual Reports of the Police Force of the Colony, AJHR H-16, 1900-1922.

Ancillary Licences and Other Matters Committee, Report, AJHR, 1979, I.15.

Appendices to the Journals of the House of Representatives, Miscellaneous Reports:

'Returns Relative to Licensing Committees etc', AJHR 1882, H.37

'Local Option Polls and Licensing Elections', AJHR 1890, H.30

R.S. Hawkins SM, “Prohibition” in Clutha Licensing District', AJHR 1897, H.35

'Liquors Sent Into the District of Mataura during the First Year of No-License', AJHR 1905, H.29A

'Returns Showing Offences During Two Years Before and Two Years After NoLicense', AJHR 1909, H.29A

'Liquors Sent Into No-License Districts, Charges and Convictions for Offences, and Numbers and Ages of Persons Convicted for Drunkenness in No-License Districts During 1912', AJHR 1913, H.30

'No-License Districts', AJHR 1914, H.28

'No-License Districts', AJHR 1915, H.28

'Local-Option and National-Licensing Polls', AJHR 1947, H.33B

'The Local-Option and General Licensing Polls 1954', AJHR 1955, H.33B

'Licensing Polls', AJHR 1961, H.33B.

Chief Inspector of Primary Schools 1921 Report, Appendix A of 'Report on Primary Education', AJHR 1921, E.2.

Committee on Licensing 1960, AJHR 1960, I .17.

Committee on the Sale of Liquor Bill, Report, AJHR 1987-1990, volume xviii, I.23A.

Department of Health, Observations on Alcohol in Relation to the Human Body and Mind, Wellington, 1921. 
Department of Statistics, Justice Statistics of New Zealand, 1920-1976.

Department of Statistics, New Zealand Censzs of Population and Dwellings 1966, volume 1.

Department of Statistics, New Zealand Population Statistics, 1947-1976.

Department of Statistics, Provisional Report on Population and Dwellings, Wellington, 1966.

Financial Statement of the Minister of Finance, AJHR, 1918-1923, B.6.

Lash, Barb, Young People and Alcohol: Some Statistics to 2003 and 2004 on Possible Effects of Lowering the Purchase Age, Ministry of Justice, Wellington, 2005.

Licensing Control Commission Annual Reports 1952-1980, AJHR , H.3.

Licensing Control Commission Annual Reports 1981-1989, AJHR , E.8.

Liquor Licensing Authority Annual Reports, 1990-2000, AJHR, E.8.

Ministerial Committee into Violence, Report, Wellington, 1987.

Ministry of Health and Alcohol Advisory Council, National Alcohol Strategy 2000-2003, Wellington, 2001.

Ministry of Health, National Drug Policy Part 1: Tobacco and Alcohol, Wellington, 1996.

National Efficiency Board, 1917 Report, AJHR 1917, H.43.

National Efficiency Board, 'Report on the Liquor Question', AJHR 1917, H.43A.

New Zealand Gaqette, 1919, 1920, 1949, 1967.

New Zealand Official Year Book, 1894-2002

New Zealand Parliamentary Debates 1871-1873, 1880-81, 1916-1918, 1944-48, 1960-62, 1967, 1989.

New Zealand Statutes:

Alcoholic Liquors Sale Control Act 1893

Alcoholic Liquors Sale Control Amendment Act 1895

Alcoholic Liquors Sale Control Amendment Act 1904

Customs Amendment Act 1921

Customs and Duties Excise Act 1888

Electoral Amendment Act 1945

Finance Act (No. 2) 1921

Finance Act 1915

Finance Act 1917

King-country Licenses Act 1909

Licensing Act 1881

Licensing Act 1908

Licensing Acts Amendment Act 1904 
Licensing Amendment Act (No. 2) 1953

Licensing Amendment Act 1910

Licensing Amendment Act 1918

Licensing Amendment Act 1948

Licensing Amendment Act 1960

Local Elections and Polls Act 1908

Local Restoration Polls Act 1990

Sale of Liquor Act 1962

Sale of Liquor Act 1989

Sale of Liquor Amendment Act 1976

Sale of Liquor Amendment Act 1999

Sale of Liquor Poll Act 1967

Sale of Liquor Restriction Act 1917

Shops and Offices Act 1908.

Nordmeyer, A.H., Budget 1958, AJHR 1958, B.6.

Parliamentary Licensing Committee, Report, AJHR 1922, I.14.

Police Force of the Colony Annual Reports 1900-1923, AJHR, H.16.

Prime Minister's Strategy Unit, Alcohol Harm Reduction Strategy for England, London, 2004.

Royal Commission on Licensing, Proceedings, 53 volumes, Wellington, 1946.

Royal Commission on Licensing, Report, Wellington 1946.

Royal Commission on the Police Force of New Zealand, Report and Evidence, AJHR 1898, H.2.

Royal Commission on the Sale of Liquor in New Zealand: Transcripts, 5 volumes, Wellington, 1974.

Royal Commission to Inquire Into and Report Upon the Sale of Liquor in New Zealand, The Sale of Liquor in New Zealand, Wellington, 1974.

Schedule of Petitions, Journal of the House of Representatives, 1877.

Select Committee on Violent Offending, Report, AJHR 1979, I.18.

Statistics New Zealand, 'Household Expenditure 1998' accessed at www.stats.govt.nz.

Statistics New Zealand INFOS database Table ALCQ.SAL1

Statistics New Zealand, Propensity to Travel of New Zealand Residents: Overseas Trips by New Zealanders' in 'Tourism and Migration 2000', December 2001, available at http://www.stats.govt.nz/analytical-reports / tourism-migration-2000/default.htm, accessed 20 October 2005.

Statistics New Zealand, 'Spirits and Spirits-based Drinks Available for Consumption' in 'Alcohol and Tobacco Available for Consumption, Year ended December 2004', available from www.stats.gort.nz, accessed 10 February 2006. 
Statistics New Zealand, 'Technical Notes' in Alcohol and Tobacco Available for Consumption, Year Ended December 2004, Wellington, 2005.

Tourist and Publicity Department Annual Reports 1960-1963, AJHR, H.6.

Tourist and Publicity Department Annual Reports 1964-1968, AJHR, H.3.

Transport Department, Annual Report for year ending 31 March 1937, AJHR 1937-8, H.40.

Working Party on Liquor, The Sale of Liquor in New Zealand, Wellington, 1986.

\section{Official Sources - Unpublished}

Justice Department submission to the Royal Commission on the Sale of Liquor, Archives New Zealand COM 21/8, 1973, Submission 18.

Licensing Control Commission file, 'Suggested Changes in Licensing Hours', Archives New Zealand AADM, 567, 13e, 4/1/26.

Licensing Control Commission file 13a, LCC/AUC, Archives New Zealand AADM 678.

Licensing Control Commission file 58a, LCC/MAN, Archives New Zealand AADM 678.

Licensing Control Commission file 115a, LCC/CAN, Archives New Zealand AADM 678.

National Efficiency Board Minute Book, Vol. 1, 2 February 1917 to 6 July 1918, New Zealand National Efficiency Board: Minutes, qMS-1528-1529, Alexander Turnbull Library.

Royal Commission on the Sale of Liquor, Submissions, Archives New Zealand, COM 21/8, 1973-4.

\section{Unofficial Sources - Published}

Adams, A.S., Professor Salmond's Blunder: Probibition an Effective Social Reform, New Zealand Alliance, Wellington, 1911.

Advisory Committee on the Shop Trading Hours Act 1977, The Shop Trading Hours Act 1977, Wellington, 1988.

Alcoholic Liquor Advisory Council, 'The Availability Issue', Sale of Liquor Act 1988: AL AC Update Number 2, Wellington, 1988.

Alcoholic Liquor Advisory Council, Living With Alcohol: a Submission to the Working Party on the Liquor Laws, Wellington, 1986.

Ausubel, David, The Ferm and the Tiki - an American View of New Zealand: National Character, Social Attitudes and Race Relations, Sydney, 1960. 
Beer, Wine and Spirits Council, 'Policy Statements', http://www.beerwsc.co.nz/page.asp?pageID=21, accessed 10 November 2005.

Cocker, Rev. J and Murray, J. Malton, eds., Temperance and Probibition in New Zealand, Wellington, 1930.

Dash, George, ed, No-License Handbook, Auckland, 1908.

Hobbs, Leslie, The Wild West Coast, Christchurch, 1959.

McKay, John (director), Fight the Good Fight, Reel Images Film Production/Television New Zealand, New Zealand Film Archive Reference Number: Film: F18007, 1980(?).

Malton Murray, J., The New Zealand Alliance Handbook: a Handy Guide for Speakers and Writers, Wellington, 1925.

McNeish, James, Tavern in the Town, Wellington, 1957.

Mill, John Stuart, 'On Liberty’ in Mary Warnock ed., Utilitarianism, London, 1971.

Milner, W. H., Control Fails, Alliance Pamphlet, Wellington, 1946.

Murray, J. Malton, The New Zealand Alliance Handbook: a Handy Guide for Speakers and Writers, Wellington, 1925.

New Zealand Liquor Industry Council, Submission to the Royal Commission on Liquor, February 1974.

Orchard, H.K., 'New Zealand Alcohol Consumption Statistics 1955-1989', Alcoholic Liquor Advisory Council, Wellington, 1990.

Pember Reeves, William, State Experiments in Australia and New Zealand, two volumes, Edinburgh, 1902.

Poster, 'Happiness depends on the home!', Alexander Turnbull Library pictorial collections, reference number Eph-C-ALCOHOL-Hours-1948-02.

Poster, 'Vote 6 o'clock closing!', Alexander Turnbull Library pictorial collections, reference number Eph-C-ALCOHOL-Hours-1948-03.

Rowntree, Joseph and Sherwell, Arthur, Public Control of the Liquor Traffic, London, 1903.

Rowntree, Joseph and Sherwell, Arthur, The Temperance Problem and Social Reform, London, 1899.

Salmond, William, Probibition: A Blunder, Dunedin, 1911.

Siegfried, Andre translated by E.V. Burns, Democracy in New Zealand, London, 1914.

Somerset, H.C.D., Littledene: A New Zealand Rural Community, Wellington, 1938 
Snow, John, 'On the Mode of Communication of Cholera', 1855, published online by UCLA School of Public Health, http://www.ph.ucla.edu/epi/snow/snowbook3.html, accessed 14 June 2005.

\section{Unofficial Sources - Unpublished}

Brewers' and Wine and Spirit Merchants' Association of New Zealand: Records, MSPapers-1621-01, Alexander Turnbull Library, Minutes of the New Zealand Licensed Victuallers' Association of New Zealand and Minutes of the Brewers' Association, 18901910.

Brewers' and Wine and Spirit Merchants' Association of New Zealand: Records, MSPapers-1621-02, Alexander Turnbull Library, Minutes of the Brewers' Association 19151918.

New Zealand Alliance Annual Accounts in New Zealand Alliance: Records, 77-206-14/9, Alexander Turnbull Library.

New Zealand Alliance Annual Report for the year ended 31 March 1932, New Zealand Alliance Annual Meeting Minutes 1932-1954, New Zealand Alliance: Records, 77-20614/07, Alexander Turnbull Library.

New Zealand Alliance Records, 77-206-06/07, Alexander Turnbull Library.

New Zealand Alliance, Minutes of Monthly Executive Meetings 1916-1917, in New Zealand Alliance Records, MSY-5655, Alexander Turnbull Library.

New Zealand Alliance, Second Report of the Alliance Special Committee, 16 July 1956, in New Zealand Alliance: Records, 77-206-06/06, Alexander Turnbull Library.

\section{Newspapers and Periodicals}

Auckland Star, 1917, 1943, 1946-1949, 1955, 1967.

Cheerio, 1922, 1925.

Dominion Post, 2004, 2006.

Dominion, 1917-1920, 1922, 1925, 1928, 1935, 1946, 1948, 1955, 1966.

Evening Post, 1919, 1967, 1981.

Grey River Argus, 1955, 1959.

Here and Now, 1951.

New Zealand Free Lance, 1917, 1945.

New Zealand Herald, 1949, 1992, 2004.

New Zealand Licensee, 1961. 
New Zealand Listener, 1967, 1974.

New Zealand Woman's weekly, 1988.

Otago Daily Times, 1946, 1949, 1967.

Probibitionist (and Direct Veto Advocate) 1890-1906.

Southland Neus, 1955.

Southland Times, 1959.

Sydney Morning Herald, 2003, 2004.

Te Awamutu Courier, 1955.

The Times (London), 2006.

V anguard, 1911-1915, 1917-1923, 1932-1933, 1947-1949, 1964, 1965.

White Ribbon, 1895-1900, 1926.

World Drink Trends, 2003.

\section{Secondary Sources}

\section{Books and Book Chapters}

The Academy of Medical Sciences, Calling Time: The Nation's Drinking as a Major Health Issue, London, 2004.

Alcoholic Liquor Advisory Council, Living With Alcobol: Preventing Misuse, Wellington, 1983.

Ashton, Toni and Casswell, Sally, From a Public Health Perspective; Aliohol Pricing Policy in New Zealand, Auckland, 1986.

Atkinson, Neill, Adventures in Democracy: A History of the Vote in New Zealand, Dunedin, 2003.

Barr, Andrew, Drink: A Social History, London, 1998.

Bassett, Michael, The State in New Zealand 1840-1984: Socialism Without Doctrines?, Auckland, 1998.

Beauchamp, Dan, E., 'The Paradox of Alcohol Policy: The Case of the 1969 Alcohol Act in Finland' in Mark H. Moore and Dean R. Gerstein, eds, Alcohol and Public Policy: Beyond the Shadow of Prohibition, Washington, 1981, pp. 225-254.

Belich, James, Paradise Reforged: A History of the New Zealanders from the 1880s to the year 2000, Auckland, 2001. 
Blocker, Jack Jr., Fahey David and Tyrrell, Ian, eds., Alcohol and Temperance in Modern History: an International Encyclopedia, Santa Barbara, 2003.

Bloomfield, G.T., New Zealand: A Handbook of Historical Statistics, Massachusetts, 1984.

Bollinger, Conrad, Grog's Own Country, Wellington, 1959.

Bollinger, Conrad, Grog's Own Country, second edition, Auckland, 1967.

Boyer, J. Patrick, Lawmaking by the People: Referendums and Plebiscites in Canada, Toronto, 1982.

Brien, Bill, 100 Years of Hospitality in New Zealand, 1902-2002, Wellington, 2003.

Brinsdon, Sandy, Alcohol Data: New Zealand Data Sourves Relating to Alcohol, Wellington, 1998.

Brogan, Hugh, Longman History of the United States of America, London, 1985.

Brookes, Barbara, Olssen, Erik and Beer, Emma, 'Spare Time? Leisure, Gender and Modernity', in Barbara Brookes, Annabel Cooper and Robin Law, eds., Sites of Gender: Women, Men and Modernity in Southern Dunedin 1890-1939, Auckland, 2003.

Brookfield, F.M., 'Referendums: Legal and Constitutional Aspects', in Alan Simpson, ed., Referendums: Constitutional and Political Perspectives, Occasional Publication no. 5, Department of Politics, Victoria University of Wellington, 1992.

Bunkle, Phillida, 'The Origins of the Women's Movement in New Zealand: The Women's Christian Temperance Union 1885-1895' in Beryl Hughes and Phillida Bunkle, eds, Women in New Zealand Society, Auckland, 1980.

Burnham, John, New Perspectives on the Prohibition "Experiment" in Paths into American Culture: Psychology, Medicine and Morals, Philadelphia, 1988.

Butler, David and Ranney, Austin, Referendums Around the World: the Growing Use of Direct Democracy, Washington D.C., 1994.

Casswell, Sally and Bhatta, Krishna, A Decade of Drinking: Auckland 1990-1999, Auckland, 2001.

Casswell, Sally and Martin, Carey, From a Public Health Perspective; Shaping Attitudes Towards Aliohol in New Zealand; Auckland, 1986.

Casswell, Sally and Stewart, Liz, From a Public Health Perspective; Availability of Alcobol in New Zealand; Auckland, 1986.

Chapman, Robert, 'From Labour to National' in W. H. Oliver with B. R. Williams eds., The Oxford History of Nem Zealand, Wellington, 1981.

Chaudron, Douglas and Wilkinson, Adrian eds., Theories on Alcoholism, Toronto, 1988.

Collins, James Jr, ed., Drinking and Crime, London, 1982. 
Coney, Sandra, Standing in the Sunshine: A History of the New Zealand Women Since They Won the Vote, Auckland, 1993.

Cooper, Michael, Wine Atlas of New Zealand, Auckland, 2002.

Cross, Gary, A Social History of Leisure Since 1600, Philadelphia, 1990.

De La Mare, Alan, Drink or Drought: Liquor Licensing and the Probibition Movement, Invercargill, 1981.

Devailant, Judith, Kate Sheppard: a Biography: the Fight for Women's Votes in New Zealand: the Life of the Woman Who Led the Struggle, Auckland, 1992.

Deverson, Tony and Kennedy, Graeme, (eds), The New Zealand Oxford Dictionary, Auckland, 2005.

Dillon, Patrick, The Much-lamented Death of Madam Geneva: The Eighteenth-century Gin Craze, London, 2002.

Dingle, A.E., The Rise and Fall of Temperance Economics, Monash Papers in Economic History no. 3, Melbourne, 1977.

Dunstall, Graeme, A Policeman's Paradise? Policing a Stable Society 1918-1945, Palmerston North, 1999.

Easton, Brian, The Corporatisation of New Zealand, Auckland, 1997.

Edwards, Griffith and Grant, Marcus eds., Alcoholism: New Knowledge and Responses, London, 1977.

Eldred-Grigg, Stevan, Pleasures of the Flesh: Sex and Drugs in Colonial New Zealand 1840-1915, Wellington, 1984.

Fairburn, Miles, The Ideal Society and its Enemies, Auckland, 1989.

Farrell, Susan, Review of National Policy Measures to Prevent Aliohol-Related Problems, Geneva, 1985.

Freer, Warren, A Lifetime in Politics, Wellington, 2004.

Freeland, J.M., The Australian Pub, Melbourne, 1966.

Godfrey, Christine and Maynard, Alan, 'An Economic Theory of Alcohol Consumption and Abuse', in Douglas Chaudron and Adrian Wilkinson, eds., Theories on Alcoholism, Toronto, 1988.

Gould, John, The Rake's Progress? The New Zealand Economy Since 1945, Auckland, 1982.

Gould, Stephen Jay, The Mismeasure of Man, New York, 1981. 
Grant, David, On a Roll: a History of Gambling and Lotteries in New Zealand, Wellington, 1994.

Gray, James, Booze: The Impact of Whiskey on the Prairie West, Toronto, 1972.

Greenaway, John, Drink and British Politics Since 1839: A Study in Policy-Making, Basingstoke and New York, 2003.

Grimshaw, Patricia, Women's Suffrage in New Zealand, revised edition, Auckland, 1987.

Habgood, Ruth, Casswell, Sally, Pledger, Megan and Bhatta, Krishna, Drinking in New Zealand: National Surveys Comparison 1995 and 2000, Auckland, 2001.

Hamer, David, The New Zealand Liberals: The Years of Power, 1891-1912, Auckland, 1988.

Hanson, David, Preventing Alcobol Abuse: Alcobol, Culture and Control, Westport, Connecticut, 1995.

Harrison, Brian, Drink and the Victorians: The Temperance Question in England 1815-1872, London, 1971.

Haydon, Peter, An Inebriated History of Britain, London, 2005.

Haydon, Peter, The English Pub: A History, London, 1994.

Heather, Nick and Robertson, Ian, Problem Drinking, $3^{\text {rd }}$ edition, Oxford, 1997.

Heron, Craig, Booze: a Distilled History, Toronto, 2003.

Holcroft, M.H., 'The Press in a Visual Age', in New Zealand's Heritage: the Making of a Nation, volume 20, Sydney, 1971.

Holland, Martin and Boston, Jonathan eds., The Fourth Labour Government: Politics and Policy in New Zealand, second edition, Auckland, 1992.

Hutt, Marten and Howden-Chapman, Philippa, 'The Making of Alcohol Policy', in Davis, Peter and Ashton, Toni eds., Health and Public Policy in New Zealand, Auckland, 2000.

Jackson, H.R., Churches and People in Australia and New Zealand, 1860-1930, Wellington, 1987.

Jackson, Keith, The Dilemma of Parliament, Wellington, 1987.

Jurgeleit, M.D., 'Figuratively Speaking' in New Zealand Liquor Industry Council, Papers Presented at the News Media Forum of the New Zealand Liquor Industry Council, Wellington, 1973.

Kelsey, Jane, Rolling Back the State, Wellington, 1993.

Kelsey, Jane, The New Zealand Experiment, Auckland, 1995.

Kirkby, Diane, Barmaids: a History of Women's Work in Pubs, Cambridge, 1997.

Lawlor, Pat, Old Wellington Hotels: Some History, Personalities and Anecdotes, Wellington, 1974 
LeDuc, Lawrence, Niemi, Richard and Norris, Pippa, eds., Comparing Democracies: Elections and Voting in Global Perspectives, Thousand Oaks, California, 1996.

Levine, Stephen and Robinson, Alan, The New Zealand Voter: a survey of public opinion and electoral behairour, Wellington, 1976.

Levine, Stephen, The New Zealand Political System: Politics in a Small Society, Sydney, 1979.

Lewis, Milton, A Rum State: Alcohol and State Policy in Australia, Canberra, 1992.

Lind, Clive, Pubs, Pints and People: 50 Years of the Invercargill Licensing Trust, Invercargill, 1994.

MacBeth Williams, Tannis, ed., The Impact of Television: A Natural Experiment in Three Communities, London, 1986.

Macdonald, Charlotte, ed., The Vote, the Pill and the Demon Drink: A History of Feminist Writing in New Zealand, 1869-1993, Wellington, 1993.

Macdonald, Charlotte, Penfold, Merimeri and Williams, Bridget, eds,. The Book of New Zealand Women, Wellington, 1991.

MacDonald, I., Stone, H. M. and Dick, G. L., 'The Problem of the Intoxicated Driver' in H. M. Stone, ed., Alcobol, Drugs and the New Zealand Driver, Wellington, 1982.

Makela, Pia, Rossow Ingeborg, and Tryggvesson, Kalle, 'Who drinks more and less when policies change? - The evidence from 50 years of Nordic studies', in Robin Room, ed., The Effects of Nordic Alcobol Policies: What Happens to Drinking and Harm When Controls Change?, Helsinki, 2002.

Malcolm, Elizabeth, Ireland Sober, Ireland Free: Drink, and Temperance in Nineteenth-Century Ireland, Dublin, 1986.

Manson, Kenneth, When the Wine is Red: the New Zealand Temperance Alliance centennial review, 1886-1986, Wellington.

McClure, Margaret, The W onder Country: Making New Zealand Tourism, Auckland, 2004.

Martin, John, Holding the Balance: A History of New Zealand's Department of Labour 1891-1995, Christchurch, 1996.

Mathison, Sandra ed., Encyclopedia of Evaluation, Thousand Oaks, California, 2005.

McGill, David, The Guardians at the Gate: The History of the New Zealand Customs Department, Wellington, 1991.

McLauchlan, Gordon, The Story of Beer: Beer and Brewing - a New Zealand History, Auckland, 1994.

Mulgan, Richard, Politics in New Zealand, Second Edition, Auckland, 1997.

Nolan, Melanie, Breadwinning: New Zealand Women and the State, Christchurch, 2000. 
Nordlund, Sturla, 'Norway' in Jack Blocker Jr., David Fahey and Ian Tyrrell, eds., Alcohol and Temperance in Modern History: an International Encyclopedia, Santa Barbara, 2003, pp. 458462.

Olssen, Erik, 'Waging War: the Home Front 1914-1918' in Judith Binney, Judith Bassett, Erik Olssen, eds., The People and the Land; Te Tangata me Te Whenua: An Illustrated History of New Zealand 1820-1920, Wellington, 1990.

Orsman, Elizabeth and Harry, The New Zealand Dictionary, Second Edition, Auckland, 1995.

Orsman, Harry, ed, A Dictionary of Modern New Zealand Slang, Auckland, 1999.

Page, Dorothy and Department of Internal Affairs, The Suffragists: Women Who Worked for the Vote: Essays from the Dictionary of New Zealand Biography, Wellington, 1993.

Phillips, J.O.C., A Man's Country? The Image of the Pakeha Male - a History, Auckland, 1987.

Plaut, Thomas, Aliobol Problems: A Report to the Nation by the Cooperative Commission on the Study of Alcoholism, New York, 1967.

Room, Robin, ed., The Effects of Nordic Alcohol Policies: What Happens to Drinking and Harm When Controls Change?, Helsinki, 2002.

Room, Robin; Romelsjo, Anders and Makela, Pia, 'Impacts of alcohol policy: the Nordic experience', in Robin Room, ed., The Effects of Nordic Alcohol Policies: What Happens to Drinking and Harm When Controls Change?, Helsinki, 2002.

Rorobaugh, W. J., 'Alcohol, Consumption of, per Capita (U.S.)' in Jack Blocker Jr., David Fahey and Ian Tyrrell, eds., Alcohol and Temperance in Modern History: an International Encyclopedia, Santa Barbara, 2003, pp. 22-4.

Searle, G. R., The Quest for National Efficiency: A Study in British Politics and Political Thought, 1899-1914, Los Angeles, 1971.

Sharp, Andrew ed., Leap into the Dark: the Changing Role of the State in New Zealand Since 1984, Auckland, 1994.

Simpson, Tony, 'The Demon Drink is Wide Awake!' in Shame and Disgrace: A History of Lost Scandals in New Zealand, Auckland, 1992.

Sinclair, Keith, Walter Nash, Auckland, 1976.

Sournia, Jean-Charles, A History of Alioholism, Oxford, 1990.

Southwick, L. H., Dormer, Alan and G.R. Halford, The Liquor Laws of New Zealand, Wellington, 1983.

Stace, Michael, A History of the Liquor Legislation in New Zealand, Wellington, 1988. 
Stewart, Liz and Casswell, Sally, From a Public Health Perspective; Control of Drinking on Licensed Premises in New Zealand., Auckland, 1986.

Thom, Betsy, Dealing with Drink - Aliobol and Social Policy: From Treatment to Management, London, 1999.

Thomas Babor et al, Alcohol: No Ordinary Commodity: Research and Public Policy, Oxford, 2003.

Timberlake, James, Prohibition and the Progressive Movement 1900-1920, Cambridge, Massachusetts, 1963.

Tod, Frank, Pubs Galore: History of Dunedin Hotels 1848 - 1984, Dunedin, 1984.

Tyrrell, Ian, Sobering Up: From Temperance to Probibition in Antebellum America, 1800-1860, Connecticut, 1979.

Tyrrell, Ian, Woman's World, Woman's Empire: The Woman's Christian Temperance Union in International Perspective, 1880-1930, North Carolina, 1991.

Walker, Geoffrey, Initiative and Referendum: The People's Law, Sydney, 1987.

Watson, James, Links: A History of Transport and New Zealand Society, Wellington, 1996.

Wigley, John, The Rise of the Victorian Sunday, Manchester, 1980.

Wood, G.A. and Rudd, Chris, The Politics and Government of New Zealand; Robust, Innovative and Challenged, Dunedin, 2004.

Wood, Pamela, Dirt: Filth and Decay in a New World Arcadia, Auckland, 2005.

Wright, Clare, Beyond the Ladies Lounge: Australia's Female Publicans, Melbourne, 2003.

Wyllie, Allen, Millard, Margaret and Zhang, Jia Fang, Drinking in New Zealand: A National Survey 1995, Auckland, 1996.

Valentine, J.M., Alcohol and Public Policy: Working Paper for the Prevention Review, Alcoholic Liquor Advisory Council, Wellington, 1982.

\section{Articles}

Ashenden, A.H, Brookes, R.H. and Robinson, A.D., 'Attitudes towards liquor among New Zealand voters’, Political Science, Volume 18, no 1, March 1966.

Barton, G.P., 'Smith, David Stanley 1888 - 1982', Dictionary of New Zealand Biography, updated 4 April 2003, http://www.dnzb.govt.nz/.

Beer Wine and Spirits Council of New Zealand, 'Quality Rises as Volumes Flatten', Facts and Figures, The Council, 2001.

Brody, Howard et al, 'Map-making and myth-making in Broad Street: the London cholera epidemic, 1854', The Lancet, 1 July 2000, v. 356, issue 9223. 
Bryder, Linda, 'Lessons' of the 1918 Influenza Epidemic in Auckland', NZJH, volume 16, no. 2, October 1982 .

Bush, Graham, 'Davis, Ernest Hyam 1872 - 1962'. Dictionary of New Zealand Biography, updated 16 December 2003, URL: http://www.dnzb.gort.1nz/.

Cannon, Edmund and Cipriani, Giam Pietro, 'Euro-illusion: A Natural Experiment', Discussion Paper 03/556, Department of Economics, University of Bristol, December 2003, available at:

http://www.efm.bris.ac.uk/economics/working papers/pdffiles/dp03556.pdf, accessed 15 June 2005.

Dills, Angela and Miron, Jeffrey, 'Alcohol Prohibition and Cirrhosis' in American Law and Economics Review, volume 6, number 2, 2004, pp. 285-318.

Dingle, A.E., 'The Truly Magnificent Thirst: An Historical Survey of Australian Drinking Habits', Historical Studies, vol. 15 no. 75, October 1980.

Gorman, D.M., 'Alcohol Availability and Domestic Violence', American Journal of Drug and Aliohol Abuse, November 1998, accessed at wwww. findarticles.com on 28 June 2004.

Grigg, Anthony, Prohibition and Women: The Preservation of an Ideal and a Myth', NZJH, vol. 17, no. 2, October 1983.

Grigg, Anthony, 'Prohibition: the Church and Labour - a programme for social reform, 1890 - 1914' in NZJH, vol. 15, no. 2, October 1981.

Grigg, Anthony, 'Viable Option or Vote Splitter?', Comment, November 1981, no. 14, pp. 15-19.

Hunt, William F, 'Hunt, William Duffus 1867 - 1939'. Dictionary of New Zealand Biography, updated 31 July 2003, URL: http://www.dnzb.govt.nz/.

Jurgeleit, M.D., 'Figuratively Speaking' in New Zealand Liquor Industry Council, Papers Presented at the News Media Forum of the New Zealand Liquor Industry Council, Wellington, 1973

Kerr, William; Middleton Fillmore, Kaye, and Marvy, Paul, 'Beverage-specific alcohol consumption and cirrhosis mortality in a group of English-speaking beer-drinking countries', Addiction, March 2000, vol 95, no. 3, pp. 339-347.

Marmot, Michael, 'The Rising Tide of Alcohol', Addition, September 2004, vol. 99. no. 9, p. 1090.

Meyer, Bruce, 'Natural and Quasi-Experiments in Economics', Journal of Business and Economic Statistics, volume 13, no. 2, April 1994.

Mulcare, Timothy, 'The Political Economy of Six O'clock Closing', New Zealand Institute for the Study of Competition and Regulation research paper, Wellington, 1999, available at www.iscr.org.nz.

New Zealand Police, 'Operation Machine Gun - Walker and Speight murders’; www.police.govt.nz/operation/machinegun, accessed 3 December 2004. 
Newbold, Greg, 'Dallard, Berkeley Lionel Scudamore 1889 - 1983', Dictionary of New Zealand Biography, updated 4 April 2003, http://www.dnzb.govt.nz.

Newman, Richard, 'New Zealand's Vote for Prohibition in 1911', NZJH, vol. 9, no. 1, April 1975, pp. 52-71.

Nieuwenhuysen, John, 'Liquor control policy and alcohol availability-consumption relationships: reflections on the Victorian debate', in Australian Drug and Alcobol Review $1988 ; 7: 263-271$.

Phillips, Walter, "Six O'Clock Swill': The Introduction of Early Closing of Hotel Bars in Australia', Historical Studies, vol. 19 no. 75, October 1980, pp. 250-266.

Prince, John, 'Look Back in Amber: The General Licensing Poll in New Zealand, 1919 1987, Political Science, July 1996.

Rantanen, Miska, 'Nearly 140 years of Finnish alcohol regulation' in Helsingin Sanomat: International Edition, 26 August 2003, available at www2.helsinginsanomat.fi/English/archive/news.asp?id=20030826IE13, accessed 17 April 2004.

Roche, Ann, 'The shifting sands of alcohol prevention: rethinking population control approaches', Australian and New Zealand Journal of Public Health, 1997, vol. 21, no. 6, pp. 621-625.

Stace, F. Nigel. 'Ferguson, William 1852 - 1935'. Dictionary of New Zealand Biography, updated 7 July 2005, available at http://www.dnzb.gort.nz.

Stacpoole, John, 'Gunson, James Henry 1877 - 1963'. Dictionary of New Zealand Biography, updated 31 July 2003, URL: http://www.dnzb.govt.nz/.

Stone, R.C.J., 'Myers, Arthur Mielziner 1867 - 1926'. Dictionary of New Zealand Biography, updated 16 December 2003, URL: http://www.dnzb.govt.nz.

US Library of Congress Country Studies, 'Finland - Services for Substance Abusers', available at countrystudies.us/finland/71.htm, accessed 29 June 2004.

Zhang, Jia-Fang and Casswell, Sally, 'The effects of real price and a change in the distribution system on alcohol consumption', Drug and Alcohol Review, Dec 1999, vol. 18, no. 4 , pp. 371-9.

\section{Theses and Research Essays}

Biggs, Geoffrey, 'Some Political and Social Implications of Later Closing', MA thesis in Political Science, Victoria University of Wellington, 1970.

Bogle, Mark, 'Objectives and Performance of Licensing Trusts in New Zealand', MMP Research Paper, Victoria University of Wellington, 1983.

Christoffel, Paul, 'Crime and the Maori: An Historical Perspective', BA Honours Research Essay, Victoria University of Wellington, 1988. 
Dalton, Sarah, 'The Pure in Heart: the New Zealand Women's Christian Temperance Union and Social Purity, 1885-1930', MA thesis in History, Victoria University of Wellington, 1993.

Early, Steven, 'The Six O'Clock Closing Debate', Post-Graduate Diploma in History Research Essay, University of Otago, 1991.

Fergusson, Steven, 'Class at the Margins: The Canterbury Hotel Workers' Union 1908 to 1978', MA thesis in History, University of Canterbury, 1985.

Grigg, Anthony, 'The Attack on the Citadels of Liquordom: A Study of the Prohibition Movement in New Zealand, $1894-1914$ ', PhD thesis in History, University of Otago, 1977.

Knowles, Hillary, 'Promoting Prohibition: The New Zealand Alliance for the Abolition of the Liquor Traffic's Campaign 1914 to 1920', BA Honours Research Essay, Massey University, 2002.

Malthus, K, 'The Liquor Problem in New Zealand', MA thesis in History, University of Canterbury, 1948.

McKimmey, Paul, 'The Temperance Movement in New Zealand 1835 - 1894', MA thesis in History, University of Auckland, 1968.

Mollison, Janette, 'The 38 Year Drought: Prohibition in Invercargill 1906-1943', a Research Essay completed for the Postgraduate Diploma in History, University of Otago, 1988.

Moore, Linda, 'Gender Counts: Men, Women and Electoral Politics 1893-1919', MA thesis in History, University of Canterbury, 2004.

Mulcare, Timothy, 'The Control of Alcoholic Beverage Markets in New Zealand', PhD thesis in Economic History, Victoria University of Wellington, 2001.

Paterson, Fraser, 'An Historical Analysis of Issues Within the Presbyterian Church of New Zealand 1945 - 1985’, Master of Theology thesis, University of Otago, 1985.

Thornton, Edith, 'A History of the Prohibition Movement in New Zealand,' MA thesis in History, Canterbury University College, 1936.

Turney, Craig, 'The New Zealand Alliance and Auckland 1905 - 1920', MA thesis in History, University of Auckland, 1996.

West, Edwin, 'From Pea, Pie and Pud to Nouvelle Cuisine: The History of Eating Out in Dunedin, 1935 to 1980', BA Honours History Research Essay, University of Otago, 2000.

Wright, Jason, 'Company of Strangers: Patea and Wanganui Hotels, 1866-1899', MA thesis in History, Massey University, 2004. 